Geraldo Rubens Ramos de Freitas

Efeitos do uso de globulina antitimócito e de everolimo nas subpopulações de linfócitos $T$ e $B$ do sangue periférico em receptores idosos de transplante renal

Tese apresentada à Faculdade de Medicina da Universidade de São Paulo para obtenção do título de Doutor em Ciências

Programa de Nefrologia

Orientador: Prof. Dr. Elias David Neto

Coorientador: Prof. Dr. Nelson Zocoler Galante

(Versão corrigida. Resolução CoPGr 6018/11, de 13 de outubro de 2011. A versão original está disponível na Biblioteca da FMUSP)

São Paulo

2019 
Dados Internacionais de Catalogação na Publicação (CIP)

Preparada pela Biblioteca da

Faculdade de Medicina da Universidade de São Paulo

@reproduçāo autorizada pelo autor

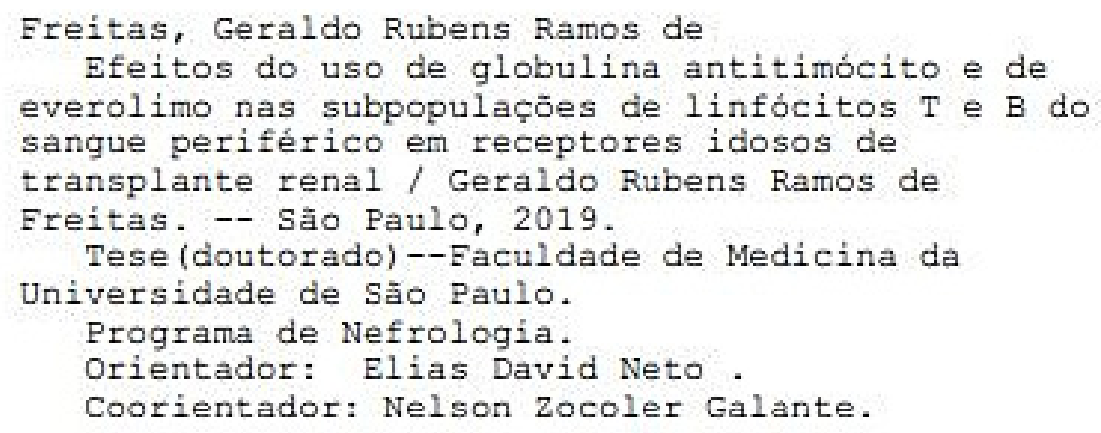


Freitas, Geraldo Rubens Ramos

Efeitos do uso de globulina antitimócito e de everolimo nas subpopulações de linfócitos T e B do sangue periférico em receptores idosos de transplante renal / Geraldo Rubens Ramos de Freitas. -- São Paulo, 2019.

Tese (doutorado)--Faculdade de Medicina da Universidade de São Paulo.

Programa de Nefrologia.

Orientador: Elias David-Neto

Co-Orientador: Nelson Zocoler Galante

Descritores: 1.Transplante de rim 2.Linfócitos T 3.Linfócios B 4.Senescencia celular 5.Envelhecimento 6.Everolimo 7.Tacrolimo

USP/FM/DBD-290/10 


\section{Dedicatória}

Dedico este manuscrito aos meus familiares, pelos momentos em que me apoiaram e pelos momentos em que me ausentei.

Em especial dedico ao meu filho Enzo Rocha Freitas e à minha esposa Lucila Soares que estiveram sempre ao meu lado.

Ainda dedico à minha mãe Americilda Rezende Ramos de Freitas e à minha sogra Ione Soares da Silva Rocha pelo auxilio nos cuidados de meu filho quando me ausentei. 


\section{Agradecimentos}

Como todo trabalho científico, nada é realizado integralmente por um único indivíduo. Mas alguns membros da equipe de trabalho têm especial destaque.

Agradeço especialmente à amiga Maria da Luz responsável pelo meu treinamento no laboratório e responsável pela análise de várias amostras avaliadas.

Agradeço ao Dr. Nelson Zocoler Galante por me orientar em tema inédito em minha formação. A maior parte das concepções deste trabalho e de suas análises foram possíveis pela expertise do Dr. Nelson no tema.

Agradeço à Dra. Verônica Coelho por disponibilizar seu laboratório e também por todas as segundas feiras à tarde em que nos encontramos para debater imunologia nestes anos. Agradeço ainda pela oportunidade de discutir a ciência em uma amplitude maior, discutindo temas por vezes, além da biologia.

Agradeço à toda equipe do laboratório de imunologia do INCOR com que trabalhei estes anos. Aqui não irei nomear todos grandes colegas para não incorrer no risco de esquecer alguém.

Agradeço ainda a equipe de pesquisa clínica da unidade de transplante renal do hospital das clínicas da USP e à equipe do ambulatório de idosos saudáveis do departamento de nefrologia da USP.

Agradeço ao Dr. Elias pelo estímulo de todos participantes da unidade de transplante renal em realizarem trabalhos científicos e discussões científicas regulares, viabilizando vários projetos, dentre estes, a presente tese de doutorado. 


\section{Normalização adotada}

Esta dissertação ou tese está de acordo com as seguintes normas, em vigor no momento desta publicação: (ABNT).

Referências: adaptado de Associação Brasileira de Normas Técnicas

Universidade de São Paulo. Faculdade de Medicina. Divisão de Biblioteca e Documentação. Guia de apresentação de dissertações, teses e monografias. Elaborado por Anneliese Carneiro da Cunha, Maria Julia de A. L. Freddi, Maria F. Crestana, Marinalva de Souza Aragão, Suely Campos Cardoso, Valéria Vilhena. 3a ed. São Paulo: Divisão de Biblioteca e Documentação; 2011.

Abreviaturas dos títulos dos periódicos de acordo com List of Journals Indexed in Index Medicus. 


\section{Lista de abreviaturas, símbolos e siglas}

\begin{tabular}{|c|c|}
\hline AdDRC & Adultos jovens com doença renal crônica \\
\hline AdISP & $\begin{array}{l}\text { Adultos jovens receptores de transplante renal com } \\
\text { imunossupressão padrão }\end{array}$ \\
\hline AdS & Adultos jovens sadios \\
\hline ANOVA & Análise de variância \\
\hline APC & Allophycocyanin \\
\hline APC-H7 & Allophycocyanin-H7 \\
\hline ATG & Globulina antitimócito \\
\hline$A Z A$ & Azatioprina \\
\hline BM & Linfócitos B memória \\
\hline BREG & Linfócitos $B$ reguladores \\
\hline CD & Cluster differentiation \\
\hline CMV & Citomegalovírus \\
\hline CTL & Controle \\
\hline CTLA4 & Cytotoxic T lymphocyte associated protein 4 \\
\hline DATASUS & Departamento de informática do sistema único de saúde \\
\hline DF & Doador falecido \\
\hline DMSO & Dimetilsulfóxido \\
\hline DN & Duplo negativo \\
\hline DP & Diálise peritoneal \\
\hline DRC & Doença renal crônica \\
\hline DRPAD & Doença renal policistica autossômica dominante \\
\hline DV & Doador vivo \\
\hline EST & Estimulada \\
\hline EVL & Everolimo \\
\hline $\mathrm{F}$ & Feminino \\
\hline FITC & Fluorescein isothiocyanate \\
\hline FMO & Fluorescencia menos um \\
\hline Foxp3 & Forkhead box P3 \\
\hline FSC & Forward scatter \\
\hline GITR & Glucocorticoid induced TNFR family related protein \\
\hline HD & Hemodiálise \\
\hline HLA & Human leukocyte antigen \\
\hline IC & Inibidor da calcineurina \\
\hline IdCEv & $\begin{array}{l}\text { Idosos receptores de transplante renal com conversão } \\
\text { precoce para everolimo }\end{array}$ \\
\hline IdDRC & Idosos com doença renal crônica \\
\hline IdISP & $\begin{array}{l}\text { Idosos receptores de transplante renal com } \\
\text { imunossupressão padrão }\end{array}$ \\
\hline IdS & Idosos sadios \\
\hline IL & Interleucina \\
\hline
\end{tabular}




$\begin{array}{ll}\text { IPEX } & \text { Desregulação imune, poliendocrinopatia, enteropatia, } \\ \text { Linf } & \text { liagada ao X } \\ \text { M } & \text { Linfócitos } \\ \text { MPA } & \text { Masculino } \\ \text { MPS } & \text { Ácido micofenólico } \\ \text { mTOR } & \text { Micofenolato sódico } \\ \text { NFKB } & \text { Mammalian target of rapamycin } \\ \text { PE } & \text { Fator nuclear Kb } \\ \text { PECY7 } & \text { Phycoerythrin } \\ \text { PERCP-CY5.5 } & \text { Phycoerythrin-Cy7 } \\ \text { Pred } & \text { Peridinin Chlorophyll Protein Complex - Cy5.5 } \\ \text { RAS/MAPK } & \text { Prednisona } \\ \text { RPMl } & \text { RAS / mitogen activated protein kinase } \\ \text { SFB } & \text { Meio de Roswell Park Memorial Institute } \\ \text { SM } & \text { Soro fetal bovino } \\ \text { SSC } & \text { Switched memory } \\ \text { TAC } & \text { Side scatter } \\ \text { TCD4 } & \text { Tacrolimo } \\ \text { TCD8 } & \text { Linfócito T CD4 (auxiliares) } \\ \text { TCM } & \text { Linfócito T CD8 (citotóxico) } \\ \text { TCR } & \text { Linfócito T de memória central } \\ \text { TEM } & \text { Receptor de células T } \\ \text { TEMRA } & \text { Linfócito T de memória efetora } \\ \text { TNF- } \alpha & \text { Linfócito T de memória efetora com re-expressão de RA } \\ \text { TREG } & \text { Fator de necrose tumoral } \\ \text { TRS } & \text { Linfócitos T reguladores } \\ \text { Tx } & \text { Terapia renal substitutiva } \\ \text { UM } & \text { Transplante } \\ & \text { Unswitched memory }\end{array}$




\section{LISTA DE TABELAS}

TABELA 1. ANTICORPOS CONJUGADOS A FLUOROCROMOS UTILIZADOS PARA MARCAÇÃO DE SUPERFÍCIE E INTRACELULAR ......................................................................................................................34

TABELA 2. DADOS DEMOGRÁFICOS DA AVALIAÇÃO BASAL .............................................................

TABELA 3. COMPARAÇÃO DE LINFÓCITOS ABSOLUTOS BASAIS EM INDIVÍDUOS ADULTOS JOVENS SADIOS, IDOSOS SADIOS, ADULTOS JOVENS COM DOENÇA RENAL CRÔNICA E IDOSOS COM DOENÇA RENAL CRÔNICA.

TABELA 4. COMPARAÇÃO DE LINFÓCITOS PERCENTUAIS BASAIS EM INDIVÍDUOS ADULTOS JOVENS SADIOS, IDOSOS SADIOS, ADULTOS JOVENS COM DOENÇA RENAL CRÔNICA E IDOSOS COM DOENÇA RENAL CRÔNICA

TABELA 5. ANÁLISE DE VARIÂNCIA (ANOVA) BIFATORIAL PARA DRC, IDADE E INTERAÇÃO IDADEXDRC .53

TABELA 6. CARACTERÍSTICAS DOS RECEPTORES AGRUPADOS POR IDADE E IMUNOSSUPRESSÃO ...56 TABELA 7. NÚMEROS ABSOLUTOS (CELS/MM³) DOS LINFÓCITOS DE DIFERENTES SUBPOPULAÇÕES AO LONGO DO TEMPO DIVIDIDOS POR IMUNOSSUPRESSÃO E IDADE.

TABELA 8. PERCENTUAIS DOS LINFÓCITOS DE DIFERENTES SUBPOPULAÇÕES AO LONGO DO TEMPO DIVIDIDOS POR IMUNOSSUPRESSÃO E IDADE.

TABELA SUPLEMENTAR 1. RESULTADO DA COMPARAÇÃO ESTATÍSTICA ENTRE OS DIFERENTES GRUPOS AO LONGO DO SEGUIMENTO

TABELA SUPLEMENTAR 2....... RESULTADO DA COMPARAÇÃO ESTATÍSTICA DA VARIAÇÃO DENTRO DE CADA GRUPO DO NÚMERO DE LINFÓCITOS AO LONGO DO SEGUIMENTO

TABELA SUPLEMENTAR 3. ...... RESULTADO DA COMPARAÇÃO ESTATÍSTICA DA VARIAÇÃO DENTRO DE CADA GRUPO DO PERCENTUAL DE LINFÓCITOS AO LONGO DO SEGUIMENTO. 


\section{LISTA DE FIGURAS}

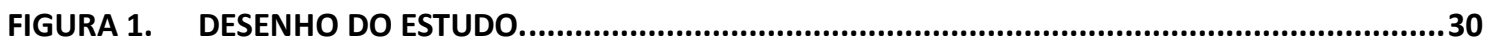

FIGURA 2. ESQUEMA PARA ANÁLISE DE CITOMETRIA DE FLUXO DAS POPULAÇÕES T. ......................36

FIGURA 3. ESQUEMA PARA ANÁLISE DE CITOMETRIA DE FLUXO DAS POPULAÇÕES B.......................36

FIGURA 4. ESQUEMA PARA ANÁLISE DE CITOMETRIA DE FLUXO DAS POPULAÇÕES T

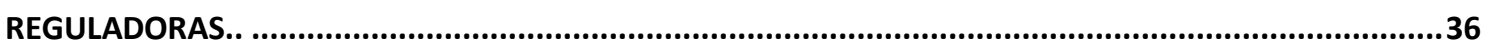

FIGURA 5. CARACTERIZAÇÃO DAS SUBPOPULAÇÕES DE LINFÓCITOS TE B EM CITOMETRIA............38

FIGURA 6. EFEITOS DE DOENÇA RENAL CRÔNICA E ENVELHECIMENTO NOS NÚMEROS (A) E PERCENTUAIS (B) DE LINFÓCITOS TOTAIS, LINFÓCITOS T-, TCD4-, TCD8- E B.

FIGURA 7. EFEITOS DE DOENÇA RENAL CRÔNICA E ENVELHECIMENTO NOS NÚMEROS (A) E PERCENTUAIS (B) DE LINFÓCITOS T NAIVE, T MEMÓRIA CENTRAL, T MEMÓRIA EFETORA E T MEMORIA EFETORA COM REEXPRESSÃO DE RA.

FIGURA 8. EFEITOS DE DOENÇA RENAL CRÔNICA E ENVELHECIMENTO NOS NÚMEROS (A) E PERCENTUAIS (B) DE LINFÓCITOS B NAIVE, B MEMÓRIA E B REGULADORES.

FIGURA 9. EFEITOS DE DOENÇA RENAL CRÔNICA E ENVELHECIMENTO NOS NÚMEROS (A) E PERCENTUAIS (B) DE LINFÓCITOS T REGULADORES.

FIGURA 10. COMPARAÇÃO DURANTE 1 ANO DOS GRUPOS DE ADISP VS. IDISP VS. IDCEV QUANTO AO NÚMERO DE LINFÓCITOS TOTAIS.

FIGURA 11. COMPARAÇÃO DURANTE 1 ANO DOS GRUPOS DE ADISP VS. IDISP VS. IDCEV QUANTO AO NÚMERO DE LINFÓCITOS T (A), T CD4 ${ }^{+}$(C) E T CD8 ${ }^{+}$(E), E AINDA, PERCENTUAIS DE LINFÓCITOS T (B), T CD4 ${ }^{+}$(D) E T CD8 ${ }^{+}$(F).

FIGURA 12. COMPARAÇÃO DURANTE 1 ANO DOS GRUPOS DE ADISP VS. IDISP VS. IDCEV QUANTO AO NÚMERO (A) E PERCENTUAL DE LINFÓCITOS B.

FIGURA 13. COMPARAÇÃO DURANTE 1 ANO DOS GRUPOS DE ADISP VS. IDISP VS. IDCEV QUANTO AO NÚMERO DE LINFÓCITOS T NAIVE (A), TMEMÓRIA CENTRAL (B), T MEMÓRIA EFETORA (C) E T MEMÓRIA EFETORA RA ${ }^{+}$(D).

FIGURA 14. COMPARAÇÃO DURANTE 1 ANO DOS GRUPOS DE ADISP VS. IDISP VS. IDCEV QUANTO AO PERCENTUAL DE LINFÓCITOS T NAIVE (A), TMEMÓRIA CENTRAL (B), T MEMÓRIA EFETORA (C) E T MEMORIA EFETORA RA ${ }^{+}$(D).

FIGURA 15. COMPARAÇÃO DURANTE 1 ANO DOS GRUPOS DE ADISP VS. IDISP VS. IDCEV QUANTO AO NÚMERO DE LINFÓCITOS T REGULADORES (A) E T REGULADORES CD39+ (B)..

FIGURA 16. COMPARAÇÃO DURANTE 1 ANO DOS GRUPOS DE ADISP VS. IDISP VS. IDCEV QUANTO AO PERCENTUAL DE LINFÓCITOS T REGULADORES (A) E T REGULADORES CD39+ (B).............66 FIGURA 17. COMPARAÇÃO DURANTE 1 ANO DOS GRUPOS DE ADISP VS. IDISP VS. IDCEV QUANTO AO NÚMERO DE LINFÓCITOS B NAIVE (A), B MEMÓRIA (B) E B REGULADORES (C)... .68

FIGURA 18. COMPARAÇÃO DURANTE 1 ANO DOS GRUPOS DE ADISP VS. IDISP VS. IDCEV QUANTO AO PERCENTUAL DE LINFÓCITOS B NAIVE (A), B MEMÓRIA (B) E B REGULADORES (C). 70 


\section{Sumário}

1. INTRODUÇÃO

1.1. ENVELHECIMENTO POPULACIONAL E AUMENTO DA DEMANDA POR TRANSPLANTE RENAL........1

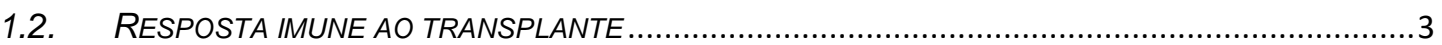

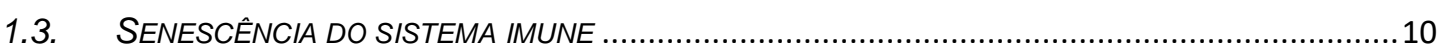

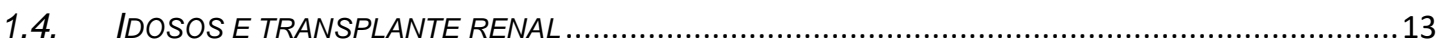

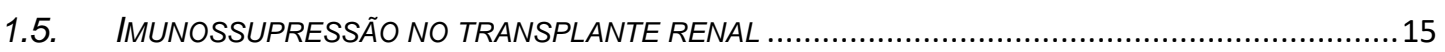

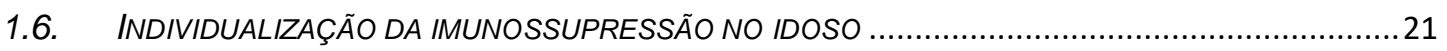

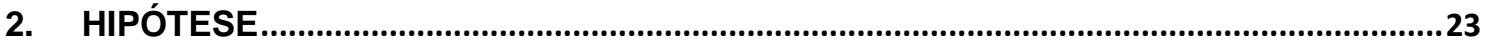

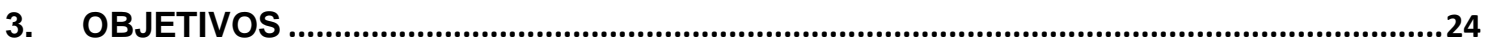

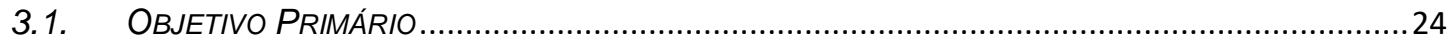

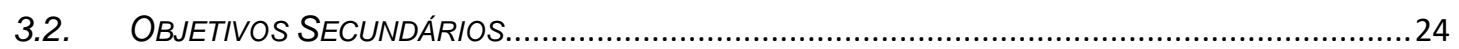

4. METODOLOGIA

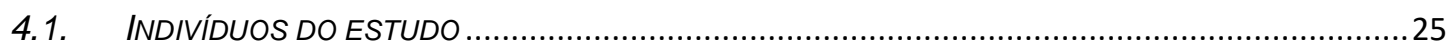

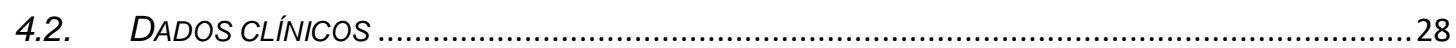

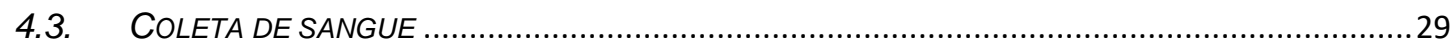

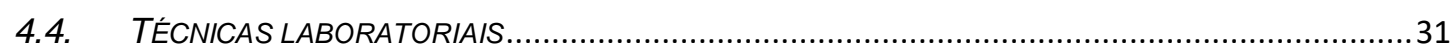

4.4.1. Separação e congelamento das células mononucleares do sangue periférico...31

4.4.2. Descongelamento das células mononucleares do sangue ................................... 32

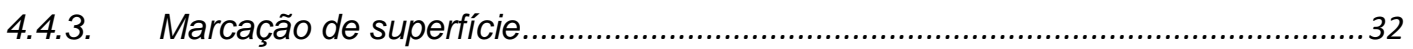

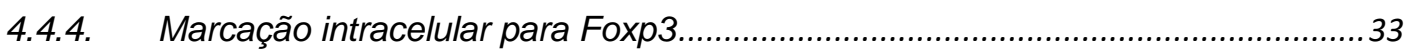

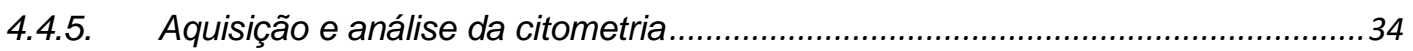

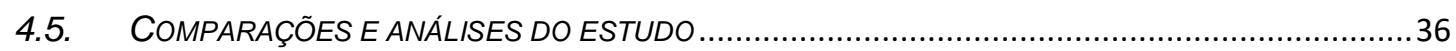

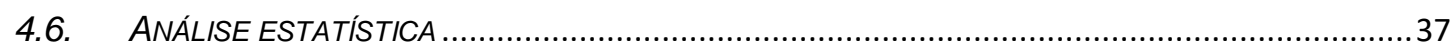

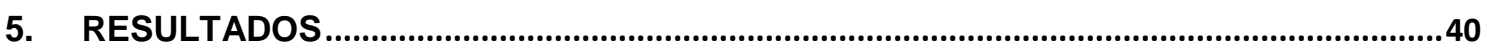

5.1. ANÁLISE DOS EFEITOS DE DOENÇA RENAL CRÔNICA E ENVELHECIMENTO …............................40

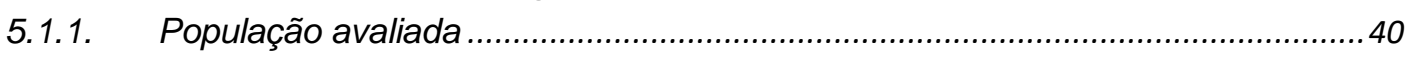

5.1.2. Efeitos do envelhecimento nas populações linfocitárias ...................................... 42

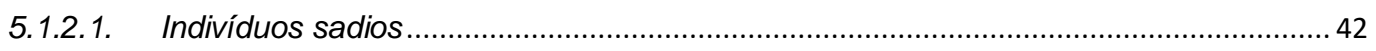

5.1.2.2. Indivíduos com doença renal crônica....................................................................... 42

5.1.3. Efeitos da doença renal crônica nas subpopulações linfocitárias.......................... 43

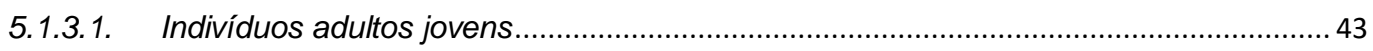

5.1.3.2. Indivíduos idosos .................................................................................................... 43

5.1.4. A interação de envelhecimento e doença renal crônica nas populações

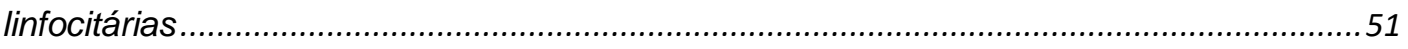

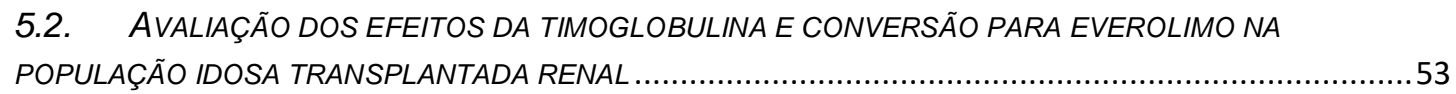

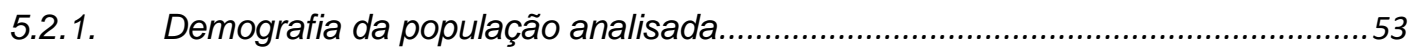

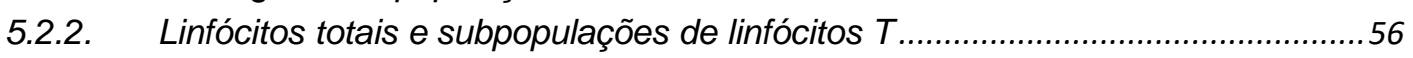

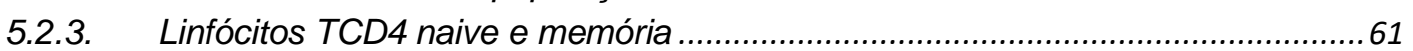

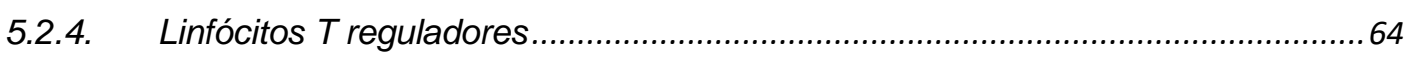

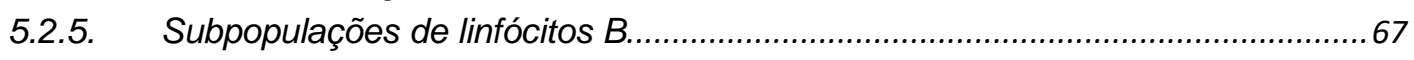

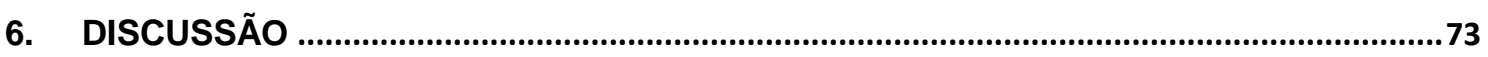

6.1. EFEITOS DE DOENÇA RENAL CRÔNICA E ENVELHECIMENTO NAS POPULAÇÕES LINFOCITÁRIAS .......73 
6.2. EFEITO DAS MEDICAÇÕES IMUNOSSUPRESSORAS NAS SUBPOPULAÇÕES LINFOCITÁRIAS DE

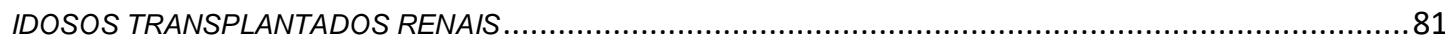

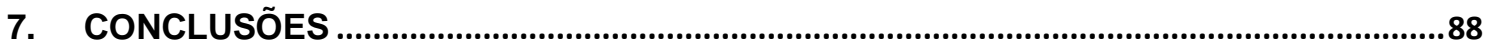

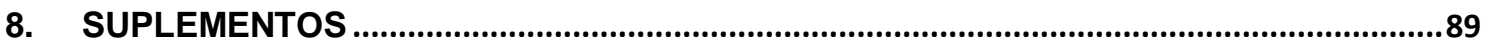

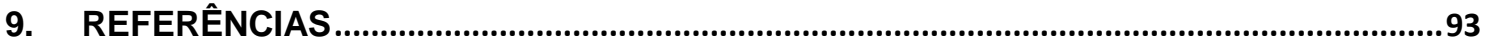


Freitas GRR. Efeitos do uso de globulina antitimócito e de everolimo nas subpopulações de linfócitos $T$ e $B$ do sangue periférico em receptores idosos de transplante renal [tese]. São Paulo: Faculdade de Medicina, Universidade de São Paulo; 2019.

Introdução: Apesar do número crescente de idosos transplantados renais, poucos estudos descrevem os efeitos de imunossupressores ou as alterações imunológicas desta população. Receptores idosos apresentam menor incidência de rejeição aguda, mas maior incidência de complicações infecciosas e neoplasias. Neste estudo avaliamos os efeitos da doença renal crônica e do envelhecimento no sistema imune de idosos candidatos a transplante, bem como efeitos da indução com globulina antitimócito (ATG) e da conversão precoce para everolimo após o transplante. Materiais e métodos: $\mathrm{Na}$ situação basal comparamos 4 grupos: a- voluntários adultos jovens sadios (AdS) $(n=14$, 26 $\pm 2 a n o s) ; ~ b-$ voluntários idosos sadios (IdS) ( $n=15,79 \pm 7$ anos); c- pacientes adultos jovens com doença renal crônica (AdDRC) ( $n=18,36 \pm 7$ anos) e; dpacientes idosos com doença renal crônica (IdDRC) ( $n=31,65 \pm 3$ anos) antes de transplante renal. $\mathrm{Na}$ avaliação após transplante, comparamos três grupos de pacientes transplantados: a- adultos jovens ( $n=20,36 \pm 7$ anos) em uso de imunossupressão padrão (AdISP), (prednisona, tacrolimo e micofenolato sódico); b- idosos em uso de imunossupressão padrão (IdISP) ( $n=35,65 \pm 3$ anos) ou c- Idosos em imunossupressão padrão convertidos precocemente para everolimo (IdCEv) ( $n=16,65 \pm 3 a n o s)$. Todos os pacientes transplantados receberam indução com dose única de ATG $2,0 \mathrm{mg} / \mathrm{Kg}$. Foram avaliadas as populações de linfócitos $T$ e $B$ periféricos de perfis naive, memória e regulador nas análises basais e nos grupos de transplante após $0 \mathrm{~d}, 30 \mathrm{~d}, 60 \mathrm{~d}$ e $365 \mathrm{~d}$ do transplante. Resultados: Envelhecimento e doença renal crônica apresentaram efeito aditivo em reduzir os números de linfócitos T [AdS $=1737(1446-1933)$ vs. IdS $=1172(934-1360) \quad$ vs. $\quad A d D R C=1238(847-1599) \quad$ vs. $\quad I d D R C=718(484-$ 993)cels $/ \mathrm{mm}^{3}$, DRC $p<0,001$ e envelhecimento $p<0,001$ ], afetando populações memória, naive e reguladoras, mas sem efeito sinérgico. Envelhecimento [Linfócitos $T$ memória central - AdS $=6,7(5-8,5)$ vs. IdS=9,2(6,7-11,9) vs. AdDRC=5,9(3,3-8,8) vs. IdDRC $=7,7(5,2-12,4) \%, D R C p=0,39$ e envelhecimento $\mathrm{p}=0,02$ ] e doença renal crônica [Linfócitos T memória efetora - $\mathrm{AdS}=28,2(16,6$ $39,3)$ vs. IdS=31,2(23,5-43,5) vs. $A d D R C=34(25,6-45,7)$ vs. $\operatorname{IdDRC}=39,6(27,4-$ $47,6) \%$, DRC $p=0,03$ e envelhecimento $p=0,19]$ resultaram em maiores percentuais de linfócitos memória, mas efeitos opostos nas populações $T$ reguladoras $[\mathrm{AdS}=11,8(9,8-13,2)$ vs. IdS $=18,3(12,1-21,5)$ vs. $\mathrm{AdDRC}=7,3(3,2-$ 11) vs. $I d D R C=11(5,8-16) \%$, DRC $p=0,02$ e envelhecimento $p=0,04]$, com maiores percentuais associados ao envelhecimento e menores percentuais associados à doença renal crônica. A ocorrência simultânea de envelhecimento e doença renal crônica também resultou em maior percentual de células $B$ reguladoras $[\mathrm{AdS}=6,2(5,2-8,2)$ vs. IdDRC $=9,9(6,5-13,9) \%, \mathrm{p}=0,016]$. Os idosos apresentaram queda nos números dos linfócitos totais no pós-transplante recente [1310(1000-16000) vs. 910 (700-11980)cels $\left./ \mathrm{mm}^{3}, p=0,0012\right]$, mas com recuperação dos números com 1 ano [IdISP $=1130(460-1325), \quad p=0,0,625$; IdCEv=1410(805-1895) cels $\left./ \mathrm{mm}^{3}, \quad p>0,9999\right]$. Os adultos jovens não apresentaram mudanças nos números de linfócitos totais nos períodos avaliados [2100(1630-2400) vs. $1960(1270-2970)$ vs. $\left.1850(1590-2120) \mathrm{cels} / \mathrm{mm}^{3}\right]$. Tanto 
em idosos [8,2(5,3-12,9) vs. 6,7(4,4-11)\%, $\mathrm{p}=0,049]$ como em adultos jovens $[6,2(3,8-10,8)$ vs. $5,3(2,5-7,3) \%, p=0,036]$, os percentuais de linfócitos $T$ de memória central apresentaram redução transitória no pós-transplante recente com recuperação após 1 ano. No transplante tardio, idosos em imunossupressão padrão apresentavam maiores percentuais de linfócitos $\mathrm{T}$ de memória central $[21,2(10,9-28)$ vs. 8,6(5-13,5)\%, $p=0,048]$ e menores percentuais de linfócitos $T$ com reexpressão de RA comparado [7,2 (5,5-11,4) vs. 15,7(9,1-30,2)\%, $p=0,048]$ a adultos jovens. Os linfócitos $T$ reguladores apresentaram redução em seus valores percentuais tanto nos adultos jovens $[1,29(0,45-1,85)$ vs. $0,84(0,18-$ $1,82) \%, p=0,038]$ como nos idosos $[2,1(1,23-3,51)$ vs. $1,69(0,8-2,66) \%$, $\mathrm{p}=0,028$ ], entretanto, no transplante tardio nos idosos [IdISP $=2,04(0,88-2,42) \%$, $p=0,062$ e IdCEv $=0,83(0,41-1,09) \%, p=0,19]$ houve recuperação dos valores basais, enquanto nos adultos jovens os percentuais permaneceram reduzidos $[0,86(0,7-1,34) \%, p=0,016]$. Adultos jovens $[8,33(5,56-11,2)$ vs. $14,1(9,37-$ $18,95) \%, p=0,0008]$ e idosos $[6,41(3,46-8,93)$ vs. $11,5(6,46-18,8) \%, p<0,0001]$ apresentaram elevação transitória do percentual de linfócitos B com 30 dias, com elevação de números [adultos jovens - 43,98(22,57-52,21) vs. 97(37,99$123,2) \mathrm{cels} / \mathrm{mm} 3, \mathrm{p}=0,0003$ e idosos - 21,35(9,56-30,34) vs. 25,93(16,51$45,72)$ cels $/ \mathrm{mm} 3, p=0,0129$ ] e percentuais [adultos jovens - 28,2(19,25-34,88) vs. $31(22,85-37,85) \%, p=<0,0001$ e idosos $-22,5(15,4-33,78)$ vs. $31,2(20,7-$ $36,5) \%, p=0,0002$ ] de linfócitos $B$ memória, bem como redução transitória do percentual de linfócitos $B$ reguladores [adultos jovens - 7,93(5,09-10,45) vs. $4,46(3,03-5,26) \%, p<0,0001$ e idosos $-9,94(6,46-14,1)$ vs. $7,12(4,53-8,93) \%$, $\mathrm{p}<0,0001]$. Conclusões: Observamos menores números absolutos de várias subpopulações linfocitárias e polarização imunológica para perfil memória tanto para envelhecimento quanto doença renal crônica. Envelhecimento se associou a perfil mais imuno-regulador, com aumento nos percentuais de linfócitos $T$ reguladores, contrastando com doença renal crônica que reduziu os percentuais de linfócitos $T$ reguladores. O tempo para reestabelecimento das contagens linfocitárias após o uso da globuina anti-timocitos sugere que as doses habituais de ATG nos idosos deve ser reconsiderada, independente da imunossupressão de manutenção escolhida. Neste estudo, não observamos efeito favorável da ATG ou da conversão para everolimo no perfil de linfócitos reguladores. Ainda, a ATG afetou de maneira relevante as populações memória. Envelhecimento favoreceu a ocorrência de linfócitos $T$ reguladores em momentos tardios do transplante e este achado ocorreu independentemente da imunossupressão de manutenção

Descritores: Transplante de rim; Linfócitos T; Linfócios B; Senescencia celular; Envelhecimento; Everolimo; Tacrolimo. 
Freitas GRR. Antithymocyte globulin and everolimus effects on $T$ and $B$ peripheral lymphocyte profile in the elderly, kidney-transplant recipients [thesis]. São Paulo: "Faculdade de Medicina, Universidade de São Paulo"; 2019.

Introduction: Despite the growing number of kidney transplants in elderly recipients, few studies describe immunosuppression effects and immunological changes in this population. Elderly kidney transplant recipients have lower acute rejection rates, but higher occurrence of neoplasms and infection complications. We evaluated the aging effects on the immune system of these recipients, as well as induction with thymoglobulin and early everolimus conversion effects in this same population. Materials and methods: In the baseline we compared 4 groups: a- healthy adult controls (HAd) $(n=14,26 \pm 2$ years); b- healthy elderly control (HEld) $(n=15,79 \pm 7$ years); c- adults with chronic kidney disease (AdCKD) $(n=18$, $36 \pm 7 y e a r s)$ and; $d$ - elderly with chronic kidney disease (EldCKD) $(n=31$, $65 \pm 3$ years) before kidney transplantation. After transplantation, we compared three groups of transplanted patients: a- young adults ( $n=20,36 \pm 7 y e a r s)$ in standard immunosuppression (AdSI), (prednisone, tacrolimus e mycophenolate sodium); b- elderly in standard immunosuppression (EldSI) ( $n=35,65 \pm 3$ years) and c- elderly in standard immunosuppression with early everolimus conversion (EldEC) ( $n=16,65 \pm 3$ years). All patients received thymoglobulin (ATG) $2 \mathrm{mg} / \mathrm{Kg}$ as a single dose. We evaluated peripheral $T$ and $B$ lymphocytes subpopulations counts and percentages, considering naive, memory and regulatory profiles at baseline and in transplanted individuals at 0d, 30d, 60d and 365d after transplantation. Results: Aging and CKD resulted in decrease of T lymphocyte counts [HAd=1737(1446-1933) vs. $\mathrm{HEld}=1172(934-1360)$ vs. AdCKD=1238(8471599) vs. EldCKD $=718(484-993) \mathrm{cell} s / \mathrm{mm}^{3}, C K D \mathrm{p}<0,001$ and aging $\left.p<0,001\right]$, affecting naive, memory and regulatory populations. Aging and CKD presented additive effects in lymphocyte counts, but no sinergic effects. Aging [T central memory lymphocytes - $\mathrm{HAd}=6,7(5-8,5)$ vs. $\mathrm{HEld}=9,2(6,7-11,9) \quad$ vs. $A d C K D=5,9(3,3-8,8)$ vs. $E l d C K D=7,7(5,2-12,4) \%, C K D p=0,39$ and aging $\mathrm{p}=0,02]$ and $C K D$ [T effector memory lymphocytes - $H A d=28,2(16,6-39,3)$ vs. HEld $=31,2(23,5-43,5)$ vs. AdCKD $=34(25,6-45,7)$ vs. EldCKD=39,6(27,4-47,6)\%, $C K D p=0,03$ and aging $p=0,19]$ were both associated with higher percentages of memory lymphocytes but opposite effects on regulatory $\mathrm{T}$-cells [HAd $=11,8(9,8$ $13,2)$ vs. HEld $=18,3(12,1-21,5)$ vs. $A d C K D=7,3(3,2-11)$ vs. EldCKD $=11(5,8-$ $16) \%, C K D p=0,02$ and aging $p=0,04]$, with higher percentages with aging and lower percentages with CKD. The co-occurrence of aging and CKD correlated with higher percentages of regulatory B-cells $[\mathrm{HAd}=6,2(5,2-8,2)$ vs. EldCKD $=9,9(6,5-13,9) \%, p=0,016]$. Elderly patients presented decrease in total lymphocyte counts early after transplantation [1310(1000-16000) vs. 910 (70011980)cells $/ \mathrm{mm}^{3}, \quad p=0,0012$ ], with return to baseline within 1 year of transplantation $\quad[E l d S I=1130(460-1325), \quad p=0,0,625 ; \quad E l d E C=1410(805-$ 
1895)cells $\left./ \mathrm{mm}^{3}, \mathrm{p}>0,9999\right]$. The young adults had no changes in lymphocyte counts [2100(1630-2400) vs. $1960(1270-2970)$ vs. $\left.1850(1590-2120) \mathrm{cells} / \mathrm{mm}^{3}\right]$. Both, elderly $[8,2(5,3-12,9)$ vs. $6,7(4,4-11) \%, p=0,049]$ and young adults $[6,2(3,8$ $10,8)$ vs. $5,3(2,5-7,3) \%, p=0,036]$, presented decrease in central memory Tlymphocytes percentages early after transplantation, with return to baseline within 1 year. Elderly in standard immunosuppression presented higher percentages of central memory T-cells $[21,2(10,9-28)$ vs. $8,6(5-13,5) \%, p=0,048]$ and lower percentages of effector memory $\mathrm{T}$-cells with RA reexpression $[7,2(5,5-$ $11,4)$ vs. $15,7(9,1-30,2) \%, p=0,048$ ] later after transplantation compared to adult recipients. In elderly $[2,1(1,23-3,51)$ vs. $1,69(0,8-2,66) \%, p=0,028]$ and young adults $[1,29(0,45-1,85)$ vs. $0,84(0,18-1,82) \%, p=0,038]$, regulatory T-cells percentages decreased in early transplantation, but while in elderly the percentages returned to baseline within one year [EldSI=2,04(0,88-2,42)\%, $\mathrm{p}=0,062$ e EldEC $=0,83(0,41-1,09) \%, \mathrm{p}=0,19]$, in young adults the percentages remained lower than baseline late after transplantation[0,86(0,7-1,34)\%, $\mathrm{p}=0,016]$. Both, young adults $[8,33(5,56-11,2)$ vs. $14,1(9,37-18,95) \%, p=0,0008]$ and elderly $[6,41(3,46-8,93)$ vs. $11,5(6,46-18,8) \%, p<0,0001]$ presented an elevation in $B$ cells percentage within 30 days, with rise in counts [young adults - 43,98(22,57-52,21) vs. $97(37,99-123,2)$ cells $/ \mathrm{mm} 3, \mathrm{p}=0,0003$ and elderly $21,35(9,56-30,34)$ vs. $25,93(16,51-45,72)$ cells $/ \mathrm{mm} 3, p=0,0129]$ and percentages [young adults $-28,2(19,25-34,88)$ vs. $31(22,85-37,85) \%, p=<0,0001$ and elderly - 22,5(15,4-33,78) vs. $31,2(20,7-36,5) \%, p=0,0002]$ of $B$ memory lymphocytes and lowering of $B$ regulatory percantages [young adults $-7,93(5,09-10,45)$ vs. $4,46(3,03-5,26) \%, p<0,0001$ and elderly $-9,94(6,46-14,1)$ vs. $7,12(4,53-8,93) \%$, $\mathrm{p}<0,0001]$. Conclusions: Lower counts of lymphocyte populations and memory pattern in lymphocyte composition are observed for aging and CKD. Aging presented association with regulatory profile, with higher regulatory T-cells percentages, while CKD resulted in lower percentages of regulatory T-cells. Time to refilling of peripheral lymphocyte counts after thymoglobulin infusion in elderly suggests that ATG in standard dosing should be considered, in spite of immunosuppressive maintenance regimen. We could not observe favoring of ATG or everolimus conversion on regulatory profile, although ATG modified memory lymphocyte percentages. Aging favored regulatory T-cell occurrence in late transplantation in spite of the immunosuppressive regimen.

Descriptors: Kidney transplantation; T lymphocytes; B lymphocytes; Celular senescense; Aging; Everolimus; Tacrolimus. 


\section{Introdução}

\subsection{Envelhecimento populacional e aumento da demanda por transplante renal}

Nos países em desenvolvimento, observa-se progressivo crescimento populacional e o aumento da longevidade. No ano de 2010 a população mundial foi estimada em 6,8 bilhões de habitantes, sendo 770,6 milhões o número de indivíduos com mais de 60 anos, o que corresponde a 11\% da população. Considerando o ritmo atual de crescimento da população, no ano de 2050, a população mundial será de 9,37 bilhões de habitantes. Destes, cerca de 2,1 bilhões (22\%), terão mais de 60 anos, o que corresponde a um aumento de $170 \%$ (CENSUS-BUREAU, 2016). No Brasil, a perspectiva do aumento da população de idosos é ainda maior. No Brasil, no ano de 2010, o número de habitantes foi estimado em 195,5 milhões. Destes, 19,6 milhões (10\%) tinham mais de 60 anos. Em 2050, são previstos 226,3 milhões de habitantes, sendo 66,4 milhões $(29,3 \%)$ com mais de 60 anos. O aumento da população de idosos no Brasil será de $240 \%$ (IBGE, 2014).

Uma característica do envelhecimento populacional é o aumento na prevalência de doenças crônicas, como hipertensão arterial, distúrbios metabólicos e osteodegenerativos. Dentre as doenças crônicas, inclui-se a doença renal crônica (DRC), também cada vez mais diagnosticada em indivíduos com mais de 60 anos (MEIER-KRIESCHE, et al, 2001; SARAN; et al., 2017). Nos Estados Unidos da America (EUA), em 1988, a incidência de DRC dialítica na população idosos foi de 600 casos/milhão de habitantes/ano, aumentando para 1200 em 1997 (MEIER-KRIESCHE; et al, 2001), e para 1300 
no ano de 2014 (SARAN; et al., 2017). A prevalência de DRC em idosos no período de 1996 a 2014 nos EUA aumentou de 3800 para 6200/milhão de habitantes (SARAN; et al., 2017). No Brasil, dados do departamento de informática do sistema único de saúde (DATASUS) também indicaram aumento da prevalência de DRC entre idosos. Entre os anos de 1997 a 2007 o número de idosos recebendo tratamento dialítico aumentou de 15000 para 37000 (147\%) (DATASUS, 2008).

Paralelamente ao envelhecimento populacional e ao aumento do número de idosos com DRC, cresce também o número de idosos candidatos a transplante renal (DANOVITCH; GILL; BUNNAPRADIST, 2007; MEIERKRIESCHE; KAPLAN, 2001). Observamos nos últimos anos crescimento do número de idosos nos serviços de transplante, bem como mudanças em suas características, com aumento paralelo do número de co-morbidades entre os pacientes.

A idade do receptor igual ou superior 60 anos foi considerada uma contraindicação relativa ao transplante renal. Com o aumento do número de idosos em diálise e da demanda pelo transplante renal neste grupo de pacientes, um número progressivamente maior de idosos têm sido submetidos a este procedimento, com resultados de sobrevida e qualidade de vida satisfatórios (HELDAL; et al., 2010). Com estes achados a expectativa é de que cada vez mais transplantes renais sejam realizados em receptores com maior idade.

No Serviço de Transplante Renal do Hospital das Clínicas da Universidade de São Paulo, foram realizados 188, 194 e 189 transplantes renais nos anos de 2016, 2017 e 2018, respectivamente. Dos transplantes realizados 
neste período, 39 (21\%), 50 (26\%) e 43 (23\%) pacientes, respectivamente, apresentavam idade superior a 60 anos.

Com o crescimento da população idosa transplantada e com múltiplas comorbidades, torna-se importante compreender as particularidades desta faixa etária, dentre as quais se destacam as diferenças no sistema imune.

Em primeiro momento, é importante compreender a resposta imunológica dos idosos ao transplante renal e as populações linfocitárias envolvidas. Posteriormente, é interessante estudar as diferenças existentes entre indivíduos idosos e não-idosos quanto à resposta imunológica no transplante e aos efeitos das medicações imunossupressoras. Finalmente, pode-se aventar possíveis implicações das diferenças encontradas para a personalização na condução dos transplantes em pacientes idosos.

\subsection{Resposta imune ao transplante}

Após o transplante renal, ocorre reconhecimento do tecido transplantado pelo sistema imune do receptor podendo se seguir do desencadeamento da resposta imunológica e da rejeição ao enxerto. Participam da rejeição células e mediadores tanto da imunidade inata, quanto da adquirida. As rejeições dos enxertos renais podem ser classificadas em rejeições mediadas por células e em rejeições mediadas por anticorpos, embora ambas possam coexistir.

O mecanismo da rejeição celular aguda envolve o reconhecimento de antígenos do doador pelos linfócitos T do receptor apresentados tanto por células apresentadoras de antígenos do doador (apresentação direta de antígenos) (WARRENS; et al., 1994), como por células apresentadoras de antígenos do 
receptor (apresentação indireta) (BRISCOE; et al, 2002; KRENSKY; et al., 1990; LECHLER; et al 1982; MANDELBROT, 2010). O reconhecimento dos aloantígenos pelos linfócitos $\mathrm{T}$ ocorre mediante a interação do receptor do linfócito T (TCR - do inglês T cell receptor) com moléculas HLA (HLA - do inglês, human leukocyte antigen) íntegras (apresentação direta) ou com fragmentos de peptídeos (apresentação indireta) do doador.

Após ocorrer o reconhecimento do HLA alogênico pelo TCR é iniciada a ativação do linfócito T. Para ser plenamente efetivo e desencadear a proliferação celular, o processo de ativação celular necessita receber três sinais de ativação (HALLORAN, 2004; KUMBALA; et al., 2013; MANDELBROT, 2010). Além do reconhecimento antigênico por meio do TCR, primeiro sinal, um segundo sinal de ativação é desencadeado pela interação de moléculas chamadas coestimuladoras, presentes nas superfícies das células apresentadoras de antígenos, com receptores específicos presentes na superfície dos linfócitos $\mathrm{T}$. A via de co-estímulo mais estudada é a CD28-CD80/CD86 que potencializa a ativação do linfócito T na interação com o antígeno exposto (HALLORAN, 2004; KUMBALA; et al., 2013; MANDELBROT, 2010; SAYEGH; et al., 1998). A ativação das vias 1 e 2 evolui com sinalização intracelular por três cascatas: via da calcineurina, via RAS/MAPK e via NFKB (HALLORAN, 2004; KUMBALA; et al., 2013; MANDELBROT, 2010). Todas as três vias intracelulares culminam no aumento da expressão de CD25 (receptor de IL-2 de alta afinidade) na superfície dos linfócitos e liberação de citocinas, entre elas a interleucina 2 (IL-2) (HALLORAN, 2004; KUMBALA; et al., 2013; MANDELBROT, 2010). A estimulação do CD25 pela IL-2 é o sinal 3, que ativa a via intracelular da 
mammalian target of rapamycin (mTOR) e, por fim, estimula a proliferação celular (HALLORAN, 2004; KUMBALA; et al., 2013; MANDELBROT, 2010).

A rejeição mediada por anticorpos é o processo em que linfócitos B são mais imputados. Após a exposição aos antígenos do enxerto, neste caso as moléculas HLA do doador, ocorre a apresentação destes aos linfócitos T-CD4 do receptor, que por meio de citocinas, ativam os linfócitos B. Os linfócitos B naive, uma vez estimulados, se diferenciam em linfócitos B memória ou em plasmócitos. Os linfócitos $B$ memória são perenes e podem rapidamente se converter em plasmócitos que sintetizam anticorpos anti-HLA quando novamente estimulados. Os plasmócitos formados passam a produzir os anticorpos anti-HLA específicos contra o doador. É, ainda, importante a atuação do sistema complemento para a lesão ocasionada pela rejeição mediada por anticorpos. Os anticorpos anti-HLA não ocasionam lesão tecidual direta, mas, após a fixação de complemento, ocasionam lise celular com lesão direta ou recrutam outras células do sistema imune com perfil citotóxico, como neutrófilos (COLVIN; et al., 2005).

Os linfócitos B são classicamente mais imputados com mecanismos imunológicos relacionados a produção de anticorpos após diferenciação em plasmócitos (DANOVITCH, 2010), mas, também, tem importância como células apresentadoras de antígenos e células de atividade reguladora (MAURI; et al. 2010). Ainda, sabe-se que a presença de anticorpos anti-HLA do doador aumenta a ocorrência de rejeição humoral, mas a cinética destes anticorpos ainda tem sido pouco explorada na literatura (DE CASTRO; et al., 2018).

Os linfócitos memória T e B são aqueles com maior diferenciação e capacidade de rápida resposta a antígenos específicos, sendo consideradas 
células com maior capacidade pró-inflamatória. Maior ocorrrencia de linfócitos T memória em modelos murinos se associam a menor capacidade regulatória dos linfócitos TREG em enxertos de pele (YANG; et al., 2007). Há relato de infiltrados de linfócotos $B$ memória em biópsias de rejeições agudas cortico resistentes em pacientes transplantados (ZARKHIN; et al., 2008)

As subpopulações de linfócitos $T$ são mais comumente diferenciadas pelas expressões de CD45RA e de CCR7. O CD45RA é uma isoforma da proteína panleucocitária CD45, uma proteína tirosina fosfatase transmembrana envolvida em vários processos celulares. A molécula de CD45RA é amplamente expressa nas fases iniciais de diferenciação de linfócitos $T$, sendo positiva para linfócitos T naive. Após diferenciação dos linfócitos T em memória central e efetora a molécula de CD45RA não é mais expressa. Apesar de paradoxal, a molécula de CD45RA é novamente expressa nos linfócitos T memória com reexpressão de RA, também chamados linfócitos $T$ de diferenciação terminal. A função ou mecanismo para o retorno da expressão de CD45RA em linfócitos T de diferenciação terminal é incerto. Já o CCR7 é um receptor transmembrana associado a proteína $\mathrm{G}$ que coordena a quimiotaxia dos linfócitos aos tecidos linfoides. O CCR7 é positivo nos linfócitos T naive e em linfócitos de memória central. A expressão de CCR7 nos linfócitos $T$ naive ocorre devido à sua emigração recente de órgão linfoide secundário, no caso o timo. A expressão de CCR7 nos linfócitos T de memória central é responsável por sua maior afinidade e permanência em tecidos linfoides secundários. Por se tratar de molécula associada a quimiotaxia a órgãos linfoides secundários, o CCR7 é negativo nos linfócitos diferenciados e de maior permanencia periférica, os linfócitos T de memória efetora e memória efetora com reexpressão de RA. Assim, os linfócitos 
$\mathrm{T}$ em sangue periférico mais comumente estudados são os $\mathrm{T}$ naive $\left(\mathrm{CD} 45 \mathrm{RA}^{+} \mathrm{CCR} 7^{+}\right)$, T memória central (TCM - do inglês, $T$ central memory) $\left(\mathrm{CD} 4 \mathrm{RA}^{-} \mathrm{CCR} 7^{+}\right)$, T memória efetora (TEM - do inglês, $T$ effector memory) (CD45RA-CCR7-), T memória efetora com reexpressão de RA (TEMRA - do inglês, $T$ effector memory with $R A$ re-expression) (CD45RA $\left.{ }^{+} \mathrm{CCR} 7^{-}\right)$. Uma importante característica dos linfócitos T de memória efetora com reexpressão de RA é sua baixa expressão de CD28, assim é um linfócito com alta capacidade de estimulação, por necessitar de pouca ou nenhuma ligação a molécula de coestimulo para sua ativação (BENICHOU; et al., 2017). A baixa expressão ou a ausência de CD28 em linfócitos T ocorre naqueles de memória maduros e já previamente estimulados por antígeno associado a co-estimulo, assim, apesar de contraintuitivo, denota população que não mais necessita de co-estimulo para se tornar ativado.

Os linfócitos B atuam como células apresentadoras de antígenos para os linfócitos T (JANEWAY; et al., 1987; RON; et al., 1987), originam plasmócitos responsáveis pela produção de anticorpos HLA específicos contra doador (CLATWORTHY, 2011) e, ainda, possuem atividade reguladora (BLAIR; et al., 2010).

Estudos analisando os perfis de linfócitos B no transplante renal são escassos e sua classificação imunofenotípica amplamente variável na literatura. A classificação imunofenotípica dos linfócitos B pode ser realizada pela classificação Bm1-Bm5, baseada na expressão de lgD e CD38 (BOHNHORST; et al., 2001; PASCUAL; et al., 1994; SANZ; et al.,2008) ou pela classificação $\operatorname{lgD} / \mathrm{CD} 27$, baseada no conceito da grande expressão de CD27 pelos linfócitos B de memória (KLEIN; et al., 1998). Com objetivo de melhor caracterização dos 
linfócitos B pode-se, ainda, combinar as populações definidas nas classificações lgD/CD27 e CD24/CD38 (KAMINSKI; et al., 2012).

No transplante renal é desejável o uso da menor imunossupressão possível. Assim, a busca por biomarcadores associados a evolução do enxerto e identificação de indivíduos com menor demanda de imunossupressão é constante. Dentre potenciais parâmetros para guiar a imunossupressão encontram-se a mensuração dos linfócitos com perfil regulador. Existem células de perfil regulador entre os linfócitos T (TREGs) e entre os linfócitos B (BREGs). Para compreender a importância das células reguladoras na homeostase imunológica, relata-se que alterações numéricas e de função das populações reguladoras se associam ao surgimento de doenças autoimunes como diabetes tipo 1 (LINDLEY; et al., 2005) e artrite reumatoide (EHRENSTEIN; et al., 2004) para as TREGs, e lúpus eritematoso sistêmico (BLAIR; et al., 2010) e artrite reumatoide (MA; et al., 2014) para as BREGs.

Entre receptores de transplante renal, foi observada relação inversa entre a frequência no sangue periférico de populações linfocitárias com fenótipo regulador e ocorrência de rejeição aguda de enxerto renal (SAN SEGUNDO; et al., 2010; SHABIR; et al., 2015). O número de células reguladoras também foi correlacionado com o fenômeno de tolerância operacional (BRAUDEAU; et al., 2007; SILVA; et al., 2012). Pacientes tolerantes operacionais e transplantes estáveis apresentam números de TREGs semelhantes àqueles de indivíduos saudáveis e maiores do que aqueles dos pacientes com rejeição crônica do enxerto renal (BRAUDEAU; et al., 2007). Além disto, os pacientes que apresentam episódios de rejeição aguda e menores taxas de filtração glomerular possuem menor número de TREGs em comparação a controles (SAN 
SEGUNDO; et al., 2010). Entre transplantados renais, a maior representatividade da população BREGs está relacionada a estabilidade de função do enxerto (CHERUKURI; et al., 2014) e à ocorrência de tolerância operacional (SILVA; et al., 2012). Vários fenótipos podem ser considerados para as populações reguladoras TREG e BREG.

A caracterização fenotípica dos linfócitos T reguladores apresentou ampla mudança nos últimos anos, com alguns marcadores passando a ser incluídos nas caracterizações rotineiras desta subpopulação. Os primeiros estudos com TREGs consideravam apenas a alta expressão de CD25, marcador inespecífico que é também expresso em células ativadas. Foi demonstrado que mutações no gene forkhead box P3 (Foxp3), transcrito na proteína scurfina/Foxp3, se associavam, em modelos murinos, à doença inflamatória intestinal e que a correção do nível de expressão de Foxp3 nestes modelos, se associava a resolução da doença. Ainda, em humanos, a mutação de Foxp3 se associa a síndrome IPEX (desregulação imune, poliendocrinopatia, enteropatia, ligada ao X). Em 2003, associou-se a expressão do gene e da proteína Foxp3 em linfócitos com sua função reguladora (HORl; et al., 2003). A expressão de FoxP3 é considerada, na literatura, a principal marcadora das células TREGs. Em 2006, foi demonstrada a baixa expressão do receptor de IL-7 (CD127) nas TREGs de pacientes diabéticos tipo 1 e em murinos. Além disto, demonstrou-se que a expressão de Foxp3 suprime a expressão de CD127 nestas células (LIU; et al., 2006). Assim, a partir de 2006, passou a ser frequente o uso da baixa expressão ou ausência de CD127 na caracterização dos TREGs. Dentro da população TREG pode, ainda, haver subpopulações com diferentes propriedades. Destacamos a positividade para CD39+ como marcador de população TREG de 
maior atividade (DWYER; et al., 2010). Atualmente, a maioria dos estudos consideram os marcadores CD25, CD127 e Foxp3 em combinação para caracterização dos TREGs. No entanto, pelas mudanças descritas, a caracterização dos TREGs nos estudos é heterogênea.

Por outro lado, as células B com atividade reguladora são, ainda, pouco estudadas. A caracterização fenotípica dos BREGs envolve a alta expressão de CD38 e CD24 (BLAIR; et al., 2010). Os BREGs apresentam capacidade supressora sobre células T efetoras in vitro (BLAIR; et al., 2010). O principal mecanismo pelo qual os BREGs exercem a função reguladora envolve a produção de IL-10 (FILLATREAU; et al., 2002). A capacidade da produção de IL10 proporcionalmente a TNF- $\alpha$ parece ser determinante de seu efeito regulador (CHERUKURI; et al., 2014).

Nos idosos transplantados, não há trabalhos caracterizando as mudanças específicas das populações de linfócitos T e B no decorrer do tratamento, assim como não há trabalhos avaliando os diferentes efeitos das medicações imunossupressoras nestas populações.

Devido ao crescente número de idosos transplantados, a melhor caracterização do comportamento de seu sistema imunológico torna-se relevante.

\subsection{Senescência do sistema imune}

Diversas modificações no sistema imune são observadas com o envelhecimento. A involução do timo é característica do envelhecimento e responsável pela redução da liberação de linfócitos T pelo timo, em especial, a 
população T naive (CCR7+CD45RA+) (GREGG; et al., 2005; SIMONE; et al., 2008). A redução da contribuição tímica para manutenção quantitativa do repertório T periférico culmina em expansão homeostática das células que estão na periferia (GREGG; et al., 2005; MORO-GARCÍA; et al., 2013; SIMONE; et al., 2008), aumento de sobrevida de células $T$ naive existentes e clonalidade de células com fenótipo memória (GREGG; et al., 2005; MORO-GARCíA; et al., 2013; SIMONE; et al., 2008). Isto não significa maior população T naive e menor população T memória, ao contrário, resulta em menor população T naive que se mantém sem aporte de novos linfócitos tímicos, e aumento da população T memória que mantém expansão semelhante, mas com menor variabilidade fenotípica.

Nos estudos em população idosa sadia, relata-se menor população com fenótipo T naive tanto TCD4+ ${ }^{+}\left(\mathrm{CCR} 7^{+} \mathrm{CD} 45 \mathrm{RA}^{+}\right)$(GREGG; et al., 2005; $\mathrm{KOCH}$; et al., 2008; LEFEBVRE; et al., 2012; SAULE; et al., 2006) como TCD8+ $\left(\mathrm{CCR}^{+}{ }^{+} \mathrm{CD} 45 \mathrm{RA}^{+}\right)(\mathrm{KOCH}$; et al., 2008; LEFEBVRE; et al. 2012; SAULE; et al., 2006), acompanhada de aumento de células $C D 4^{+}$e $C D 8^{+}$do fenótipo memória em todas subpopulações, isto é, de memória efetora (TEM) (CCR7-CD45RA) (SAULE; et al., 2006), de memória central (TCM) $\left(\mathrm{CCR} 7^{+} \mathrm{CD} 45 \mathrm{RA}-\right)(\mathrm{KOCH}$; et al., 2008) e de memória efetora com reexpressão de RA (TEMRA) (CCR7$\left.\mathrm{CD} 4 \mathrm{RA}^{+}\right)(\mathrm{KOCH}$; et al., 2008). Há estudos descrevendo redução numérica dos linfócitos TCD4+ e TCD8+ com o envelhecimento, mais abrupta para os linfócitos TCD8+ (FARIA; et al., 2008; SAULE; et al., 2006). Outros estudos descrevem redução mais pronunciada dos lincócitos $\mathrm{T} \mathrm{CD4}^{+}$, com inversão de relação TCD4+/TCD8+ (FERGUSON; et al., 1995; STRINDHALL; et al., 2007). 
Outro achado da senescência é a perda da expressão de CD28 pelos linfócitos T memória (MORO-GARCÍA; et al., 2013; SAULE; et al., 2006; SIMONE; et al., 2008), molécula relacionada ao co-estímulo destas células T.

Quanto à população de linfócitos $\mathrm{B}$, é descrito redução do número absoluto e percentual com a senescência (CARAUX; et al., 2010; CHONG; et al., 2005; FARIA; et al., 2008; MORBACH; et al., 2010; VENERI; et al., 2007). Há estudos descrevendo redução percentual dos linfócitos B naive $\left(C^{2} 27^{-} \lg D^{+}\right)$ (COLONNA-ROMANO; et al., 2010; MORBACH; et al., 2010) e B reguladores (BREG) (CD24 ${ }^{\mathrm{Hi}} \mathrm{Cd} 38^{\mathrm{Hi}}$ ) (MORBACH; et al., 2010) com o envelhecimento. Outros não observaram tais alterações (CARAUX; et al., 2010). A maioria dos estudos mostra aumento da representatividade das populações de linfócitos B memória switched (SM - do inglês, switched memory) (CD27+lgD-) (CHONG; et al., 2005; COLONNA-ROMANO; et al., 2006; MORBACH; et al., 2010), linfócitos B memória unswitched (UM - do inglês, unswitched memory) $\left(\mathrm{CD}^{2} 7^{+} \lg \mathrm{D}^{+}\right)$ (CHONG; et al., 2005; COLONNA-ROMANO; et al., 2006; MORBACH; et al., 2010) e linfócitos B memória dupla negativa (DN) (CD27-lgD-) (BULATI; et al., 2011; MORBACH; et al., 2010) com o envelhecimento.

Quanto às células reguladoras, na maioria dos estudos observa-se que a população TREG $\left(\mathrm{CD} 4{ }^{+} \mathrm{CD} 25^{\mathrm{Hi}}\right)$ nos idosos apresenta maior percentual que em adultos (FARIA; et al., 2008; GREGG; et al., 2005; LEFEBVRE; et al., 2012). Descreve-se ainda aumento do número absoluto da população TREG, mas sem alterações na razão TREG/TCD4+ (FARIA; et al., 2008). Além disso, as células TREG $\left(\mathrm{CD}^{+}{ }^{+} \mathrm{CD} 25^{+} \mathrm{FoxP}^{+}\right)$de idosos mantém a capacidade de inibir a proliferação de células $T$ efetoras $\left(\mathrm{CD}^{+}{ }^{+} \mathrm{CD} 25\right)$ in vitro (GREGG; et al., 2005; LEFEBVRE; et al., 2012; SIMONE; et al., 2008). 
Considerando o aumento da população idosa com DRC e crescente número de transplantes renais em idosos com as características imunológicas previamente descritas, é importante conhecer as implicações clínicas do sistema imune senil no contexto do transplante.

\subsection{Idosos e transplante renal}

A população idosa transplantada renal apresenta incidência de episódios de rejeição aguda aproximadamente 40\% menor (DANOVITCH; et al., 2007; MEIER-KRIESCHE; et al., 2001; MEIER-KRIESCHE; et al., 2000) do que a de adultos, mas uma mortalidade associada à infecção cerca de seis vezes maior (MEIER-KRIESCHE; et al., 2001; MEIER-KRIESCHE; et al., 2000). Os idosos transplantados apresentam, ainda, maior incidência de neoplasias (JASSAL; et al., 1997).

A idade é considerada fator independente para a ocorrência de disfunção crônica do enxerto (MEIER-KRIESCHE; et al., 2000), mas a dislipidemia (GUIJARRO; et al., 1995; MCLAREN; et al., 2000), a hipertensão arterial (OPELZ; et al., 1998), a presença de reatividade a aloanticorpos e de anticorpos doador específico (ABE; et al., 1997; HALLORAN; 1999) também estão associados.

Apesar da menor incidência de rejeição aguda, os idosos apresentam maior taxa de perda de enxerto quando comparados à população jovem, mesmo excluindo-se as perdas por morte (DANOVITCH; et al., 2007; MEIERKRIESCHE; et al., 2001). A disfunção crônica do enxerto é a principal causa de perda de enxerto entre os idosos transplantados (MEIER-KRIESCHE; et al., 
2000). A disfunção crônica do enxerto se caracteriza por deterioração lenta de sua função sem alterações histológicas específicas de um mecanismo. No entanto, há relatos de que as causas de perda tardia de enxerto são, em sua maioria, identificáveis em biópsias mais precoces (EINECKE; et al., 2009; ELZOGHBY; et al., 2009; NAESENS; et al., 2014), e que a fibrose intersticial e atrofia tubular são habitualmente secundárias a algum evento imunológico (ELZOGHBY; et al., 2009), em destaque, a rejeição crônica mediada por anticorpos, definida como causa de piora de função em até $63 \%$ dos casos de disfunção crônica de enxerto (EINECKE; et al., 2009).

Os estudos clínicos realizados para avaliar a segurança e eficácia de imunossupressão habitualmente não incluem receptores idosos, assim há poucos resultados diretamente aplicáveis para esta população específica. Desta forma, a imunossupressão utilizada nos idosos não é diferente da utilizada na população geral, apesar das características imunológicas distintas deste grupo. A maior taxa de infecções e menor incidência de episódios de rejeição aguda entre idosos transplantados reforçam a necessidade de se pesquisar formas individualizadas de imunossupressão para esta população. Por exemplo, nosso grupo identificou alterações na farmacocinética de tacrolimo e everolimo em idosos, com redução da depuração corpórea total destas drogas (DAVID-NETO; et al., 2016; DAVID-NETO; et al., 2017). O mesmo, no entanto, não ocorreu com ácido micofenólico (ROMANO; et al., 2019). 


\subsection{Imunossupressão no transplante renal}

A imunossupressão habitual em transplantes renais consiste em indução, seguida de imunossupressão de manutenção. A indução pode ser realizada com um anticorpo antagonista de IL-2, habitualmente o basiliximab, um anticorpo monoclonal quimérico dirigido contra a cadeia- $\alpha$ do receptor da interleucina-2 (antígeno CD25), ou anticorpos policlonais contra linfócitos, como a globulina antitimócito (ATG) (DANOVITCH, 2010).

A ATG é um imunobiológico imunossupressor utilizado amplamente na indução de transplantes renais e no tratamento de episódios de rejeição aguda. A ATG é composta de anticorpos policlonais dirigidos a timócitos. Apresenta em sua composição anticorpos contra moléculas comuns a células $\mathrm{T}$ e $\mathrm{B}$, e ainda alguns específicos de células T e B (ZAND, 2006; ZAND; et al., 2005).

A ATG ocasiona rápida depleção do número absoluto das células $T$ $\left(\mathrm{CD3}^{+}\right)$(BOUVY; et al., 2013; KHO; et al., 2012; SEWGOBIND; et al., 2009; TANG; et al., 2012) com recuperação parcial ao longo do tempo em até 02 anos de seguimento (BOUVY; et al., 2013; KHO; et al., 2012; SEWGOBIND; et al., 2009), exceto quando utilizado em baixa dose, registrando-se, nestes casos, recuperação de contagem basal com até 1 ano (KHO; et al., 2012). Os linfócitos TCD4+ são os mais afetados (BOUVY; et al., 2013; GURKAN; et al., 2010; SEWGOBIND; et al., 2009; TANG; et al., 2012), podendo levar até 1,5 anos para apresentar recuperação parcial (BOUVY; et al., 2013; GURKAN; et al., 2010; SEWGOBIND; et al., 2009; TANG; et al., 2012). A depleção dos linfócitos TCD4+ ocorre principalmente às custas da população T naive (BOUVY; et al., 2013; GURKAN; et al., 2010; SEWGOBIND; et al., 2009; TANG; et al., 2012), 
associada à elevação percentual da população T memória (BOUVY; et al., 2013; GURKAN; et al., 2010; SEWGOBIND; et al., 2009). Há estudos em que se relata predomínio de efeito sobre subpopulações de TCM (SEWGOBIND; et al., 2009), outros sobre TEM (BOUVY; et al., 2013; GURKAN; et al., 2010).

As células TCD8 ${ }^{+}$apresentam redução após exposição à ATG (BOUVY; et al., 2013; GURKAN; et al., 2010; SEWGOBIND; et al., 2009; TANG; et al., 2012), ocorrendo recuperação completa em até 6 meses (BOUVY; et al., 2013; GURKAN; et al., 2010). A proporção de células naive e de memória pode se manter (BOUVY; et al., 2013), mas há publicações que relatam elevação tardia da subpopulação memória (GURKAN; et al., 2010).

Após uso da ATG a reconstituição dos linfócitos TCD4+ e TCD8+ ocorre, inicialmente, pela população emigrante tímica naive (GURKAN; et al., 2010) e, posteriormente, pela proliferação homeostática da população $T$ periférica, principalmente do fenótipo memória (BOUVY; et al., 2013; GURKAN; et al., 2010). A presença de emigrantes tímicos apresenta correlação inversa com a idade (GURKAN; et al., 2010).

Alguns estudos mostram que a ATG ocasiona redução da contagem absoluta de TREGs (KRYSTUFKOVA; et al., 2012; SEWGOBIND; et al., 2009) com posterior retorno a valores basais (SEWGOBIND; et al., 2009). Outros trabalhos mostram maior resistência da população TREG à depleção pela ATG e, consequentemente, elevação percentual (GURKAN; et al., 2010; KRYSTUFKOVA; et al., 2012; TANG; et al., 2012).

Estudos in vitro, com cultura de linfócitos de voluntários saudáveis, indicam que a ATG aumenta o percentual de linfócitos TCD4+ com expressão de CD25 de forma dose dependente (LOPEZ; et al., 2006), assim como percentual 
de linfócitos $\mathrm{CD} 4{ }^{+} \mathrm{CD} 25^{+}$com expressão das moléculas associadas a fenótipo regulador, tais como, GITR, CTLA4 e FoxP3 (LOPEZ; et al., 2006). Ao mesmo tempo, linfócitos de pacientes que utilizaram ATG apresentam ex vivo, manutenção da capacidade imunossupressora das TREGs (SEWGOBIND; et al., 2009).

A não interferência da ATG na função imunossupressora da população TREG (SEWGOBIND; et al., 2009), associada à redução da capacidade proliferativa da população T efetores in vitro (SEWGOBIND; et al., 2009), acarreta predomínio da função reguladora do compartimento de linfócitos T após uso de ATG in vivo (SEWGOBIND; et al., 2009).

Há poucos estudos sobre o efeito da ATG na população de linfócitos B e a maioria não avalia as diferentes subpopulações, nem parâmetros funcionais destas células. Em diversos estudos, a exposição à ATG não altera a população de linfócitos B totais (GURKAN; et al., 2010; SEWGOBIND; et al., 2009; TANG; et al., 2012). No entanto, há relato de que altas doses de ATG $(6 \mathrm{mg} / \mathrm{Kg})$ ocasionem redução na população de linfócitos B (KHO; et al., 2012), seguida de rápida recuperação. Gurkan et al demonstraram redução percentual tardia (6 meses após transplante renal) na subpopulação $B$ memória $\left(\mathrm{CD}^{2} 7^{+} \lg \mathrm{D}^{-}\right)$ (GURKAN; et al., 2010), podendo esta ser consequência de efeito tardio da medicação, ou secundária a mudanças nas outras subpopulações linfocitárias (GURKAN; et al., 2010).

A imunossupressão de manutenção pode ser realizada com a combinação das seguintes medicações: prednisona (PRED); inibidores da calcineurina (ICN), tacrolimo (TAC) ou ciclosporina; agentes antiproliferativos, derivados do ácido micofenólico (MPA - do inglês, mycophenolic acid) ou 
azatioprina (AZA); inibidores da mTOR, sirolimo ou everolimo (EVL) (DANOVITCH, 2010).

Para as medicações utilizadas na imunossupressão de manutenção há compreensão do seu mecanismo de ação nos linfócitos, mas não há consenso sobre as populações em que tenham maior atuação, tampouco justificativa fisiopatológica para ação preferencial em alguma subpopulação linfocitária. No entanto, parecer haver subpopulações preferencialmente influenciadas por cada medicação.

Dentre os ICN, o TAC é a medicação de uso mais frequente. Os ICN são amplamente utilizados na imunossupressão, sendo parte do protocolo padrão da maioria dos serviços americanos (HART; et al., 2019). O TAC in vivo e in vitro ocasiona redução de população BREG e da produção da citocina reguladora IL10 (CHUNG; et al., 2014). O efeito do TAC na população TREG é controverso. Há estudos mostrando que o TAC não acarreta mudanças da população TREG in vivo (CHUNG; et al., 2012), outros mostrando que aumenta população TREG in vitro (KOGINA; et al., 2009) ou, até mesmo, reduz população TREG in vitro (MIROUX; et al., 2012). No entanto, o TAC in vitro não inibe a função reguladora das TREGs existentes (MIROUX; et al., 2012).

Os antiproliferativos de maior uso são os derivados do MPA, micofenolato sódico (MPS - do inglês, mycophenolate sodium) ou micofenolato de mofetil, sendo parte da imunossupressão padrão na maior parte dos centros de transplante americanos (HART; et al., 2019). Estudos in vitro indicam que o MPA é capaz de inibir a proliferação de células T naive (CD45RA+CD25) e memória (CD45RO+CD25') (HE; et al., 2011). Após 6 dias de cultivo, as células T com MPA mostraram, ainda, aumento do percentual de células com expressão de 
CTLA-4 e FoxP3 (HE; et al., 2011). Em estudos clínicos, o MPA inibiu a capacidade proliferativa de linfócitos T totais (SANKATSING; et al., 2008) e aumentou a população TREG (CD4+CD25+FoxP3+) (DEMIRKIRAN; et al., 2009). Ademais, O MPA, in vitro, inibe proliferação de linfócitos B e produção de anticorpos (HEIDT; et al., 2008). O MPA é, ainda, capaz de induzir apoptose de linfócitos B in vitro (HEIDT; et al., 2008) e de inibir sua diferenciação em plasmócitos (KARNELL; et al., 2011).

Os inibidores da mTOR são representados pelo sirolimo e pelo EVL. São utilizados na terapia imunossupressora de manutenção de pacientes transplantados renais com menor frequência do que os ICN e do que as drogas antiproliferativas (MATAS; et al., 2014). Inicialmente o uso dos inibidores da mTOR predominava em protocolos de minimização e retirada de ICN ou em conversão por neoplasia ou intolerância a algum dos outros imunossupressores. Entretanto, estudos recentes têm encorajado o uso de inibidores da mTOR desde o início do transplante em associação a doses baixas de ICN (PASCUAL; et al., 2018).

Os estudos dos efeitos dos inibidores da mTOR sobre as populações linfocitárias analisam principalmente a população TREG. Há estudos, in vitro, mostrando que os inibidores da mTOR não reduzem a expressão de Foxp3 como os IC (BAAN; et al., 2005) e favorecem a proliferação das TREG (CD4+CD25+CD127-Foxp3+) (CHEN; et al., 2010). Há, ainda, demonstrações, in vitro, de que os inibidores da mTOR em níveis terapêuticos não inibem ação supressora das TREG $\left(\mathrm{CD}^{+}{ }^{+} \mathrm{CD} 25^{+}\right)$(COENEN; et al., 2006) e induzem conversão de células $T$ CD4 efetoras $\left(\mathrm{CD}^{+}{ }^{+} \mathrm{CD} 25^{-}\right)$periféricas em TREG $\left(\mathrm{CD} 4{ }^{+} \mathrm{CD} 25^{+}{ }^{+} \mathrm{CD} 127\right.$ Foxp3 $\left.^{+}\right)(\mathrm{CHEN}$; et al., 2010). Os estudos, in vivo, avaliando 
a influência dos inibidores da mTOR nas populações linfocitárias encontraram aumento da população TREG $\left(\mathrm{CD} 4^{+} \mathrm{CD} 25^{\mathrm{Hi}}\right.$ e $\mathrm{CD} 4^{+} \mathrm{CD} 25^{+}{ }^{+}$oxp3 $\left.{ }^{+}\right)$(BANSAL; et al., 2013; MORELON; et al., 2010), T CD4+ memória (CD45RA-CCR7 $7^{-1+}$ ) (MORELON; et al., 2010) e B memória $\left(\operatorname{lgD}^{\left.+/-C D 27^{+}\right)}\right.$(MORELON; et al., 2010), bem como, menor população $\mathrm{T}$ CD4 ${ }^{+}$naive $\left(\mathrm{CD} 45 \mathrm{RA}{ }^{+} \mathrm{CCR} 7^{+}\right)(\mathrm{MORELON}$; et al., 2010) e B naive (IgD+CD27-) (MORELON; et al., 2010), sem alterações na população T CD8+ (MORELON; et al., 2010). Os inibidores da mTOR, in vitro, inibem proliferação e produção de anticorpos em culturas de células B (HEIDT; et al., 2008), bem como induzem apoptose de células B (HEIDT; et al., 2008).

Os estudos dos efeitos dos inibidores da mTOR nas diversas subpopulações de linfócitos $B$ de pacientes transplantados são escassos e não encontramos avaliações de seu efeito sobre a população BREG.

Os inibidores da mTOR possuem, ainda, propriedades anti-angiogênicas, inibem crescimento tumoral (GUBA; et al., 2002), reduzem a incidência de neoplasias na população transplantada (KAUFFMAN; et al., 2005) e promovem regressão de hipertrofia miocárdica (PAOLETTI; et al., 2008) associada a mortalidade cardiovascular.

De maneira geral, ATG, MPA e inibidores da mTOR parecem favorecer aumento absoluto e/ou relativo das TREG e os IC reduzir ou não modificar a representatividade absoluta e/ou relativa das TREGs. O efeito destas medicações nas populações BREG não é bem estabelecido, mas MPA e inibidores da mTOR parecem reduzir a produção de anticorpos pelos linfócitos B. 


\subsection{Individualização da imunossupressão no idoso}

Visando favorecer expansão e sobrevivência de linfócitos $T$ e eventualmente B reguladores, bem como buscar esquema de imunossupressão menos agressiva em longo prazo e evitar o uso de altas doses de inibidores da calcineurina em pacientes idosos transplantados renais, propôs-se a realização de protocolo de estudo de imunossupressão nestes pacientes. O Protocolo estudado consta de indução com dose baixa e única de ATG $(2 \mathrm{mg} / \mathrm{Kg})$, administrado em até 24 horas do implante do enxerto renal, seguida de imunossupressão padrão (PRED+TAC+MPS) e conversão precoce de MPS para EVL associada à baixa dose de TAC.

O uso dos inibidores da mTOR possui além dos potenciais efeitos imunológicos nas populações reguladoras, potencial benefício na redução de incidência de neoplasias e de hipertrofia miocárdica comuns na população idosa.

Assim, no Serviço de Transplante Renal do Hospital das Clinicas da Faculdade de Medicina da Universidade de São Paulo (HC-FMUSP), com intuito de avaliar a individualização da imunossupressão na população idosa, iniciou-se um estudo prospectivo aberto randomizado controlado em receptores de transplante renal idosos, com conversão precoce (programada de 1 a 3 meses, 49 \pm 26 dias) da imunossupressão padrão (Pred, TAC e MPS) para os inibidores da mTOR, everolimo (EVL), associado à redução da dose de TAC. O estudo encontra-se em andamento desde 2012 e mantém seguimento dos pacientes já incluídos.

Não há, na literatura, estudos caracterizando simultaneamente efeitos de uremia e envelhecimento no sistema imune, tão pouco da sua interação. Ainda, 
na literatura não há estudos sobre efeitos da ATG e EVL no sistema imune da população idosa.

No presente projeto, o interesse está em avaliar o esquema proposto, com foco nas mudanças imunológicas deste, usando para tal, análises das subpopulações $\mathrm{T}$ e $\mathrm{B}$ efetora e reguladora periféricas ao longo do tempo na população avaliada em até 1 ano de transplante. 


\section{Hipótese}

Nos indivíduos idosos candidatos a transplante renal, a coexistência de senescência e uremia resultam em alterações mais pronunciadas nas subpopulações T e B de sangue periférico do que cada condição isoladamente. A diferente composição das subpopulações $T$ e $B$ de sangue periférico nos idosos após o transplante contribui para que a evolução clínica dos idosos após o transplante seja diferente em relação aos adultos jovens.

A imunossupressão de indução com ATG acompanhada de manutenção com everolimo e exposição reduzida a tacrolimo nos idosos receptores de transplante renal favorece a expansão em sangue periférico de subpopulações de linfócitos T e B com perfil regulador. 


\section{Objetivos}

\subsection{Objetivo Primário}

Determinar se terapia de indução com ATG em dose baixa $(2 \mathrm{mg} / \mathrm{Kg})$ associada à terapia de manutenção com conversão precoce para EVL modifica quantitativamente o perfil linfocitário $\mathrm{T}$ e $\mathrm{B}$, efetor e regulador em até 1 ano do transplante.

\subsection{Objetivos Secundários}

Verificar o efeito de envelhecimento e doença renal crônica nos percentuais e números absolutos das subpopulações linfocitárias T e B efetoras e reguladoras em sangue periférico em indivíduos não transplantados;

Determinar o efeito da baixa dose de ATG nos percentuais e números absolutos das subpopulações de linfócitos $T$ e $B$ efetores e reguladores em sangue periférico nos transplantados renais idosos e adultos jovens com até 1 ano do transplante;

Determinar o efeito da conversão precoce da imunossupressão para EVL nos percentuais e números absolutos das subpopulações de linfócitos $T$ e $B$ efetores e reguladores em sangue periférico nos pacientes idosos transplantados com até 1 ano do transplante renal. 


\section{Metodologia}

\subsection{Indivíduos do estudo}

Este estudo incluiu receptores de transplante renal idosos $(n=35)$ e adultos jovens $(n=20)$ e voluntários idosos sadios $(n=15)$ e adultos jovens sadios $(n=14)$. Os receptores de transplante renal eram participantes de estudo prospectivo, aberto, randomizado e controlado, realizado no Serviço de Transplante Renal do HC-FMUSP com o objetivo de avaliar os efeitos da conversão precoce para EVL associada a indução com baixa dose de ATG em idosos transplantados renais de baixo risco imunológico. O referido estudo clínico se intitula "Imunossupressão no transplante renal do idoso - tempo de repensar" e foi previamente aprovado no comitê de ética do HCFMUSP sob o número CAEE 00898312.4.0000.0068. A subanálise de desfechos imunológicos do referido estudo também foi separadamente submetida e aprovada no comitê de ética do HCFMUSP sob o número CAEE 44943215.0.0000.0068. Todos os pacientes incluídos foram abordados e instruídos sobre os riscos da pesquisa, bem como, concordaram e assinaram o termo de consentimento livre e esclarecido previsto no protocolo.

Foram incluídos 5 grupos de indivíduos neste estudo, dois grupos de voluntários saudáveis e 3 grupos de receptores de transplante renal.

Os grupos de indivíduos saudáveis incluíam somente indivíduos sem doenças crônicas como hipertensão arterial, diabetes e neoplasias, além disso, que não utilizavam medicações de uso continuo, não receberam imunizações ou apresentaram quadros infecciosos próximos à inclusão no estudo. Os voluntários 
saudáveis foram agrupados em adultos jovens sadios, com idade entre 18-45 anos e em idosos sadios, com idade $>60$ anos.

Todos os receptores de transplante renal incluídos foram submetidos ao primeiro transplante renal isolado com doador vivo ou falecido e possuíam painel classe 1 e $2<30 \%$ e não possuíam anticorpo doador específico. Os receptores de transplante renal eram inicialmente divididos em adultos jovens receptores de transplante renal, com idades entre 18-45 anos e idosos receptores de transplante renal, com idade $>60$ anos. Todos adultos jovens receptores de transplante renal receberam apenas imunossupressão padrão e foram incluídos em um único grupo. Os idosos receptores de transplante renal foram divididos em 2 grupos, mas só apresentavam diferença de tratamento/imunossupressão após a conversão para EVL, assim foram considerados separadamente apenas nas análises de efeito do EVL. Os dois grupos de idosos submetidos a transplante renal eram de idosos com imunossupressão padrão e idosos com conversão precoce para EVL.

A imunossupressão de adultos jovens e idosos receptores de transplante renal foi idêntica até 30 dias do transplante. Todos os pacientes receberam terapia de indução com metilprednisolona 500mg antes do implante e ATG dose única $(2 \mathrm{mg} / \mathrm{Kg})$ em até $24 \mathrm{~h}$ após o implante do enxerto renal. A imunossupressão de manutenção inicial foi prednisona $0,5 \mathrm{mg} / \mathrm{Kg} / \mathrm{d}$, tacrolimo $0,2 \mathrm{mg} / \mathrm{Kg} / \mathrm{d}$ e MPS $1440 \mathrm{mg} / \mathrm{d}$. A prednisona teve sua dose rapidamente reduzida para atingir $5 \mathrm{mg} / \mathrm{d}$ em 60 dias. A dose de MPS foi mantida sem alterações, a menos que necessária alteração de dose por motivos clínicos. A dose de tacrolimo foi ajustada para nível sérico entre 8-12ng/mL nos primeiros 30 dias (figura 1). 
Os grupos de adultos jovens receptores de transplante renal e idosos receptores de transplante renal de imunossupressão padrão foram mantidos com mesma imunossupressão de manutenção após 30 dias, recebendo prednisona $5 \mathrm{mg} / \mathrm{d}$, MPS $1440 \mathrm{mg} / \mathrm{d}$ e tacrolimo ajustado para nível sérico de 4$8 \mathrm{ng} / \mathrm{mL}$ (figura 1).

O grupo de idosos receptores de transplante renal de conversão precoce para EVL tiveram sua imunossupressão alterada com 30-90 dias, com introdução de EVL e retirada gradual do MPS. A imunossupressão deste grupo consistiu em prednisona $5 \mathrm{mg} / \mathrm{d}$, EVL ajustado para nível sérico de $3-8 \mathrm{ng} / \mathrm{mL}$ e tacrolimo ajustado para nível sérico de 2-4ng/mL (figura 1).

Os voluntários adultos jovens sadios foram selecionados entre colaboradores do serviço de transplante renal do HC-FMUSP e os idosos saudáveis entre indivíduos com seguimento no ambulatório de geriatria do HCFMUSP. Os voluntários saudáveis foram submetidos a apenas 1 coleta de sangue periférico no momento da inclusão no estudo.

Os receptores de transplante renal foram submetidos a mais de uma coleta de sangue periférico, de acordo com o grupo em que foram incluídos. Todos receptores de transplante renal foram submetidos a uma primeira coleta de sangue em sua admissão hospitalar antes da administração dos agentes imunossupressores e a segunda coleta com 30-60 dias do transplante renal. Sempre que possível os indivíduos receptores de transplante renal também foram submetidos a coleta de sangue periférico entre 365-455 dias do transplante renal (figura 1).

Dentre os receptores de transplante renal, o grupo de intervenção do estudo clínico, isto é, os idosos que foram convertidos precocemente para uso 
de EVL, foram submetidos a uma coleta adicional de sangue periférico com 60120 dias (30 dias após a conversão para EVL).

Não há homogeneidade nos achados sobre as mudanças nas populações linfocitárias ao longo do transplante renal na literatura e não há estudos dos efeitos dos diferentes imnossupressores nas populações linfocitárias dos pacientes idosos. Por não haver dados para embasamento, não foi calculado previamente o tamanho amostral ideal. Trata-se de estudo preliminar que poderá, no entanto, embasar cálculo amostral para estudo futuro.

\subsection{Dados clínicos}

Foram coletadas para análises neste estudo dados clínicos disponíveis no prontuário dos indivíduos do estudo. Para todos os indivíduos do estudo foram avaliados idade, gênero e presença de co-morbidades. Para os pacientes transplantados foram avaliadas características do doador, tempo de isquemia fria, painel classes 1 e 2, compatibilidade de HLA e terapia de imunossupressão empregada.

Foram também coletados dados sobre desfechos clínicos, tais como episódios de rejeição aguda, perda de enxerto, óbito e infecção por citomegalovírus (CMV).

Com 3 meses de seguimento ocorreram 1 óbito no grupo idosos com conversão precoce para everolimo (IdCEv), 1 óbito e 1 episódio de rejeição aguda nos idosos com imunossupressão padrão (IdISP), 1 episódio de rejeição aguda adultos jovens com imunossupressão padrão (AdISP). 
Com 1 ano ocorreram: 1 episódio de rejeição aguda e 1 perda de enxerto entre os IdCEv, 2 infecções por CMV, 3 novos episódios de rejeição aguda, 3 novos óbitos entre os IdISP, 4 infecções por CMV, 6 novos episódios de rejeição aguda, 3 óbitos e 1 perda de enxerto entre os AdISP.

Dos indivíduos com coleta tardia (1 ano), 1 indíviduo no grupo IdISP e 2 no grupo AdISP apresentaram rejeição aguda do enxerto. Não houve infecção por CMV precedendo qualquer das coletas realizadas.

Como o número de eventos foi pequeno, principalmente entre os indivíduos do grupo com everolimo e entre os indivíduos com todas amostras coletadas, optamos por não expor as análises das mesmas.

\subsection{Coleta de sangue}

Foram coletados $45 \mathrm{~mL}$ de sangue periférico dos pacientes e voluntários sadios em tubos contendo heparina sódica (Becton Dickinson-BD, Plymouth, Inglaterra). As amostras de sangue colhidas foram imediatamente processadas no Laboratório de Imunologia I do InCor.

Quanto às coletas dos pacientes, estas sempre foram realizadas antes da realização de hemodiálise na unidade de internação, mas não há dados de quantos pacientes realizaram hemodiálise no mesmo dia da admissão. 
Grupo de adultos jovens e idosos com imunossupressão padrão

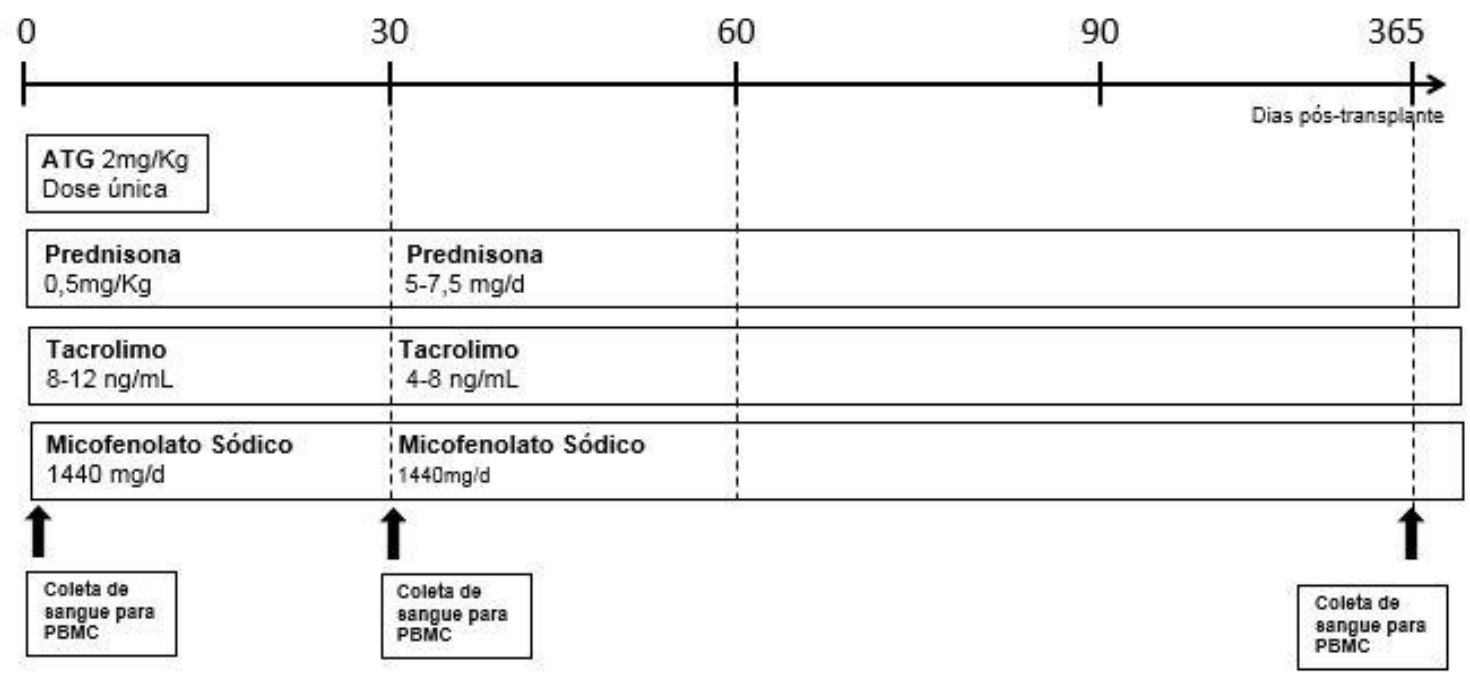

Grupo de idosos com conversão para everolimo

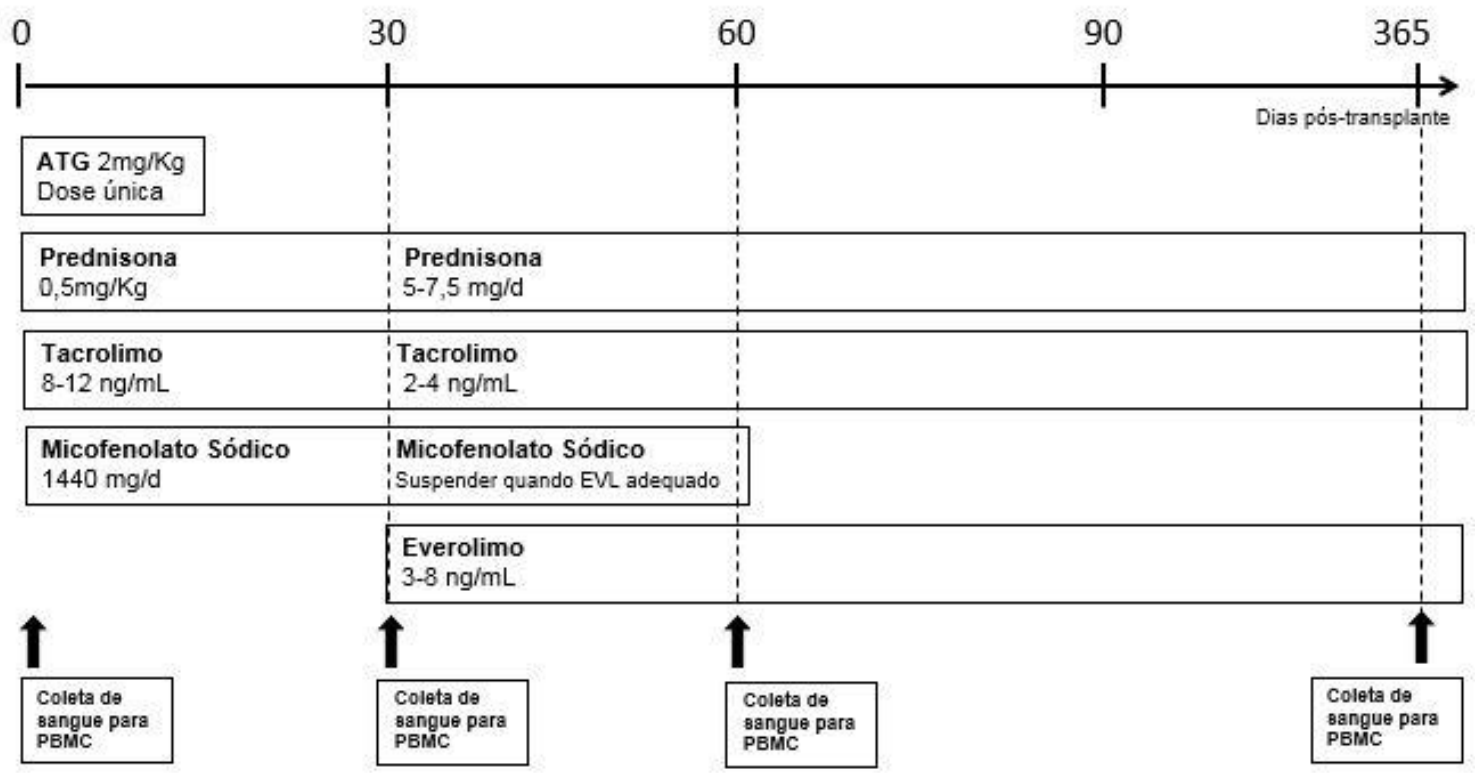

FIGURA 1. Desenho do Estudo - O sangue periférico coletado foi utilizado para realização de hemograma e imunofenotipagem de linfócitos periféricos. PBMC - células mononucleares de sangue periféricos - do inglês, peripheral blood mononuclear cells, ATG, globulina antitimócito. 


\subsection{Técnicas laboratoriais}

\subsubsection{Separação e congelamento das células mononucleares do sangue periférico}

O sangue heparinizado foi diluído 1:2 com solução de salina 0,9\% estéril. Em seguida, esta solução foi homogeneizada e distribuída sobre $12,5 \mathrm{~mL}$ de Ficoll Hypaque (Pharmacia Biotech, Sweden e Hypaque: Urografine 370, Schering, Brasil) previamente depositados em tubos de polipropileno com capacidade para $50 \mathrm{~mL}$. Os tubos foram centrifugados por 25 minutos a $800 \mathrm{~g}$. Após a centrifugação, foi coletada a nuvem de células mononucleares formada entre o Ficoll Hypaque e a salina. A nuvem foi transferida para um tubo previamente identificado e o volume transferido completado com solução salina estéril até atingir $50 \mathrm{~mL}$. Os tubos com nova solução foram centrifugados por 8 minutos a $600 \mathrm{~g}$. Em seguida, o sobrenadante foi desprezado e o botão celular suspenso em RPMI 1640 (Gibco, Grand Island, NY) sem adição de soro e suplementado com $2 \mathrm{mM}$ de L-glutamina (Gibco, Grand Island, NY), $2 \mathrm{mg} / \mathrm{mL}$ de Ciprofloxacino (Kabi, Barueri, SP) e 0,1\% de gentamicina (Santisa Laboratório Farmaceutico S/A, Bauru, SP). Os tubos foram novamente centrifugados por 8 minutos a $600 \mathrm{~g}$. Após a centrifugação, o sobrenadante foi desprezado e o botão celular suspenso em 10mL de RPMI 1640 sem adição de soro e suplementado com $2 \mathrm{mM}$ de L-glutamina (Gibco, Grand Island, NY), $2 \mathrm{mg} / \mathrm{mL}$ de Ciprofloxacino (Kabi, Barueri, SP) e 0,1\% de gentamicina (Santisa Laboratório Farmaceutico S/A, Bauru, SP). Foi realizada a contagem das células mononucleares em câmara de Neubauer utilizando-se o corante vital Azul de Tripan (MCB Manufacturing Chemists Inc., Cincinnati, OH, EUA) e a leitura feita com auxílio do microscópio óptico em aumento de 400x. Após a contagem, as amostras 
foram centrifugadas por 8 minutos a $600 \mathrm{~g}$. Em seguida, o sobrenadante desprezado e o botão celular suspenso em meio de congelamento, elaborado com $90 \%$ de soro fetal bovino (SFB) (Gibco, Grand Island, NY) e 10\% de dimetilsulfóxido (DMSO) (Sigma-Aldrich, St.Louis, MO). As amostras foram imediatamente colocadas em $-80^{\circ} \mathrm{C}$ e, após 24 horas, estocadas em nitrogênio líquido.

\subsubsection{Descongelamento das células mononucleares do sangue}

No momento do descongelamento celular os tubos de criopreservação foram retirados do nitrogênio líquido e levados rapidamente a banho-maria de 37 ำ. Antes do descongelamento completo a suspensão de células foi transferida para um tubo contendo $4 \mathrm{ml}$ de meio RPMl suplementado. As células foram imediatamente centrifugadas a $600 \mathrm{~g}$ por 8 minutos. O sobrenadante foi desprezado e o botão celular de células suspenso em $4 \mathrm{ml}$ de meio RPMI suplementado.

Em seguida, realizada nova contagem em câmara de Neubauer e teste de viabilidade celular com corante vital Azul de Tripan (MCB Manufacturing Chemist Inc. Cincinatti, OH, EUA) em microscópio óptico em aumento de 400x.

\subsubsection{Marcação de superfície}

Após descongelamento, a suspensão de células foi distribuída em tubos de $5 \mathrm{ml}$ de polipropileno e as amostras submetidas à lavagem pela adição de $2 \mathrm{ml}$ de solução tampão, constituída por $2 \%$ de tampão fosfato salino (PBS) (in 
house), $0,02 \%$ de SFB e 0,02\% azida sódica (Labsynth, Diadema, SP), seguida de centrifugação a $800 \mathrm{~g}$ por 5 minutos com posterior descarte do sobrenadante.

Para a marcação de superfície foi realizada a adição de anticorpos monoclonais conjugados com fluorocromos ao botão celular (tabela 1). As amostras foram incubadas em geladeira por 45 minutos. Após incubação as células foram novamente lavadas com solução tampão e centrifugadas a $800 \mathrm{~g}$ por 5 minutos. O sobrenadante foi mais uma vez descartado e o botão celular suspenso em $500 \mu \mathrm{L}$ de solução tampão.

\subsubsection{Marcação intracelular para Foxp3}

Após a marcação de superfície as células foram lavadas em $2 \mathrm{ml}$ de tampão e centrifugadas a $800 \mathrm{~g}$ por 5 minutos a $4 \stackrel{\circ}{\circ} \mathrm{C}$. O sobrenadante foi descartado e, em seguida, as células foram permeabilizadas e fixadas, adicionando-se $1 \mathrm{ml}$ de solução fixação / permeabilização comercial (eBiosciences, San Diego, CA) e incubadas no escuro por 60 minutos em geladeira. A seguir, as células foram lavadas em $2 \mathrm{ml}$ de solução tampão de lavagem para permeabilização (eBiosciences, San Diego, CA) e centrifugadas a $800 \mathrm{~g}$ por 5 minutos, sendo este processo de lavagem repetido mais uma vez. Após segunda lavagem, foi realizada suspensão das células em $100 \mu \mathrm{L}$ de solução tampão de lavagem para permeabilização. A seguir, acrescentado $2,5 \mu \mathrm{L}$ do anticorpo monoclonal para FoxP3 conjugado com fluorocromo (tabela 1) e incubação em geladeira por mais 45 minutos. As células já marcadas foram lavadas com $2 \mathrm{ml}$ de solução tampão de lavagem para permeabilização, 
centrifugadas a $800 \mathrm{~g}$ por 5 minutos e novamente suspensas em $500 \mu \mathrm{L}$ de tampão de lavagem.

Tabela 1. Anticorpos conjugados a fluorocromos utilizados para marcação de superfície e intracelular

\begin{tabular}{ccc}
\hline $\begin{array}{c}\text { Anticorpo } \\
\text { Monoclonal }\end{array}$ & Fluorocromo & Clone \\
\hline CD3 & APC-CY7 & SK7 \\
CD3 & FITC & SK7 \\
CD4 & FITC & OKT4 \\
CD4 & APC & SK3 \\
CD8 & AMCYAN & SK1 \\
CD8 & PE & SK1 \\
CD45 & PerCP-CY5.5 & HLe-1 \\
CD45RA & PE-CY7 & HI100 \\
CCR7 & PE & 3D12 \\
CD25 & PE & BC96 \\
CD127 & PE-CY7 & eBioRDR5 \\
CD39 & APC & A1 \\
CD19 & AMCYAN & HIB19 \\
CD24 & PECY7 & ML5 \\
CD38 & PerCP-CY5.5 & HIT2 \\
Foxp3 & PerCP-Cy5.5 & PCH101 \\
\hline FITC - do inglês fluorescein isothiocyanate, PE - do inglês Phycoerythrin, PerCp - \\
do inglês Peridinin Chlorophyll Protein Complex, APC - do inglês allophycocyanin
\end{tabular}

\subsubsection{Aquisição e análise da citometria}

Após as marcações previamente descritas foram obtidos tubos específicos para cada análise desejada. As células foram adquiridas no citômetro de fluxo modelo FACS Canto II (Beckton \& Dickinson). Para a imunofenotipagem de superfície foram adquiridos até 100.000 eventos na região dos linfócitos, determinadas pelo tamanho e complexidade celular. Já para as amostras com marcação intracelular foram adquiridos até 300.000 eventos na região dos linfócitos. Controles de fluorescencia menos um (FMO do Inglês, fluorescence minus one) foram avaliadas para os marcadores CD127, FoxP3, CD39, CCR7 (CD197) e CD45RA.

Para a análise dos dados adquiridos em citometria foi utilizado o software FlowJo 9.1 (TreeStar Inc, San Carlos, CA). Inicialmente foram excluídos os 
debris celulares e células agrupadas utilizando as distribuições FSC-H vs. FSCA, posteriormente a determinação da região de linfócitos com as variáveis FSCA vs. SSC-A. Em seguida as populações de interesse foram identificadas seguindo as estratégias de análise mostradas nas figuras 2 a 5 .

Os valores percentuais de cada população avaliada foram retirados diretamente do programa e sempre calculadas para representarem o percentual da população de interesse, a saber, linfócitos, linfócitos TCD4, linfócitos TCD4 ${ }^{+} \mathrm{CD} 25^{+}$ou linfócitos $\mathrm{B}$. Os valores absolutos foram calculados a partir da multiplicação do valor percentual que cada subpopulação representava frente aos linfócitos totais pela contagem absoluta de linfócitos do hemograma em mesma coleta.

Foi optado pela classificação dos linfócitos T com marcações por CD45RA e CCR7, dos linfócitos B com marcação por CD38 e CD24, e dos linfócitos T reguladores com marcação por CD127 e FoxP3. A escolha destes marcadores foi baseada na descrição da literatura de efeitos de imunossupressores e de variáveis clínicas utilizando-se desta caracterização fenotípica. A inclusão do marcador CD39 se baseou em recente descrição de subpopulação com maior capacidade reguladora. Assim, o uso desta classificação fenotípica permitiria comparação com diferentes estudos.

As populações linfocitárias avaliadas incluíam linfócitos totais, linfócitos T (CD3) $\left(\mathrm{CD} 45^{+} \mathrm{CD}^{+}\right)$, linfócitos T CD8 (CD8) $\left(\mathrm{CD} 45^{+} \mathrm{CD} 3^{+} \mathrm{CD} 8^{+}\right)$, linfócitos T CD4 (CD4) (CD45 $\left.{ }^{+} \mathrm{CD}^{+}{ }^{+} \mathrm{CD} 4+\right)$, linfócitos $B(C D 19)\left(C D 45^{+} \mathrm{CD} 19^{+}\right)$, linfócitos T CD4 naive $\left(\mathrm{CD}^{+}{ }^{+} \mathrm{CD} 4^{+} \mathrm{CD} 45 \mathrm{RA}^{+} \mathrm{CCR} 7^{+}\right)$, linfócitos $\mathrm{TCM} \quad\left(\mathrm{CD} 3^{+} \mathrm{CD} 4{ }^{+} \mathrm{CD} 45 \mathrm{RA}{ }^{-}\right.$ $\left.\mathrm{CCR}^{+}\right)$, linfócitos TEM $\left(\mathrm{CD}^{+}{ }^{+} \mathrm{CD} 4{ }^{+} \mathrm{CD} 45 \mathrm{RA}{ }^{-C C R 7}{ }^{-}\right)$, linfócitos TEMRA $\left(\mathrm{CD}^{+}{ }^{+} \mathrm{CD} 4^{+} \mathrm{CD} 45 \mathrm{RA}^{+} \mathrm{CCR} 7{ }^{-}\right), 2$ populações de linfócitos T CD4 reguladores 
(TREG) $\quad\left(\mathrm{CD}^{+}{ }^{+} \mathrm{CD} 4^{+}{ }^{+} \mathrm{CD} 25^{+}{ }^{+} \mathrm{CD} 127^{- \text {Foxp3 }^{+}}\right.$e $\quad \mathrm{CD}^{+}{ }^{+} \mathrm{CD} 4^{+} \mathrm{CD} 25^{+} \mathrm{CD} 127^{-}$

Foxp3+CD39+), linfócitos B naive (CD19+CD24IntCD38Int), linfócitos B memória (do inglês B memory - BM) $\left(C D 19^{+} C D 24^{+} C D 38-\right)$ e linfócitos B reguladores (BREG) $\left(\mathrm{CD} 19^{+\mathrm{CD}} 24^{\mathrm{Hi}} \mathrm{CD} 38^{\mathrm{Hi}}\right)$.

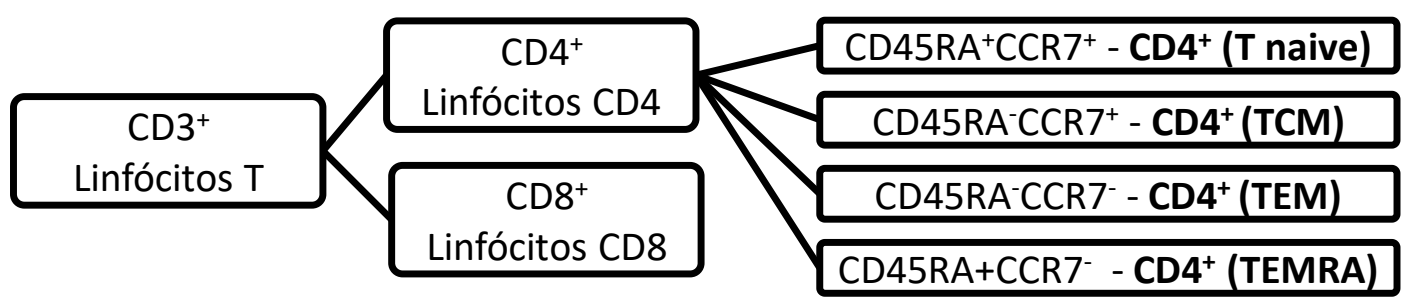

FIGURA 2. Esquema para análise de citometria de fluxo das populações T. TCM memória central, TEM - memória efetora, TEMRA - memória efetora com reexpressão de RA

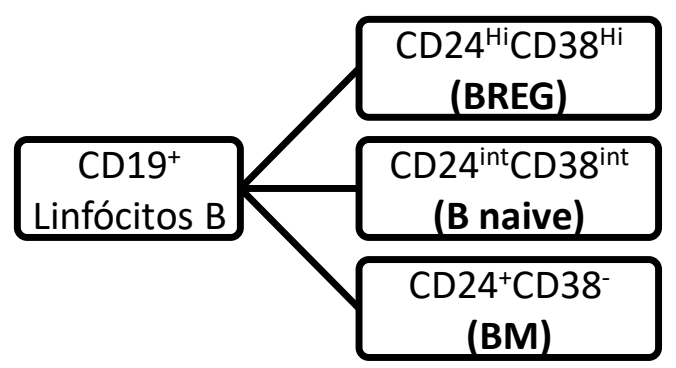

FIGURA 3. Esquema para análise de citometria de fluxo das populações $B$. BREG - B reguladora, $\mathrm{BM}-\mathrm{B}$ memoria.

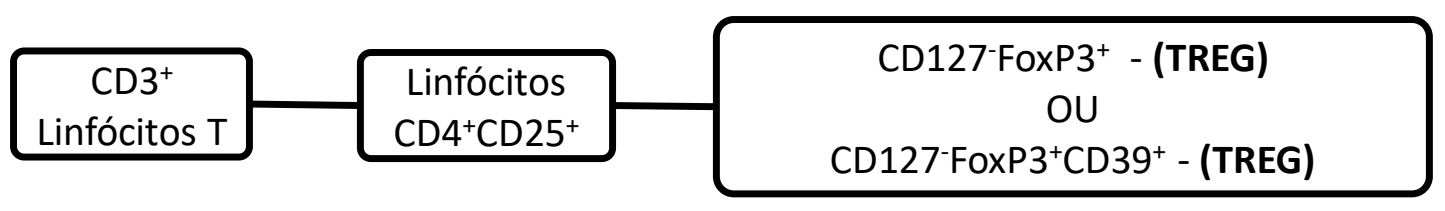

FIGURA 4. Esquema para análise de citometria de fluxo das populações T reguladoras. TREG - T reguladora.

\subsection{Comparações e análises do estudo}

Foram comparados pacientes receptores de transplante renal em situação basal e voluntários saudáveis para avaliar os efeitos da senescência e da doença renal crônica nas subpopulações linfocitárias em primeira análise. Para esta, 
foram consideradas as populações linfocitárias previamente previstas e os percentuais das populações TREGs foram analisadas dentre os linfócitos TCD4 ${ }^{+} \mathrm{CD} 25^{+}$.

Em outra análise foram comparados receptores de transplante renal antes do transplante e após transplante renal. Nesta análise, os receptores foram divididos em 3 grupos: adultos jovens com imunossupressão padrão (AdISP), idosos com imunossupressão padrão (IdISP), idosos com conversão precoce para everolimo (IdCEv). Nesta análise, temos por objetivo avaliar os efeitos da ATG e da conversão para everolimo na população idosa. As comparações foram realizadas entre os grupos nos diferentes tempos do transplante e dentro do próprio grupo considerando as coletas pareadas de cada individuo em diferentes tempos. Relembramos que, nos tempos antes do transplante e com 30 dias de transplante, todos idosos encontravam-se no mesmo grupo de imunossupressão padrão.

\subsection{Análise estatística}

As análises estatísticas e gráficos foram realizados nos programas SPSS 20 (SPSS Inc., Chicago, IL) e GraphPad Prism 6 (GraphPad Software Inc., La Jolla, CA). As diferenças observadas foram consideradas estatisticamente significativas quando o teste de comparação empregado apresentasse $p<0,05$.

As variáveis contínuas foram inicialmente avaliadas quanto à normalidade da distribuição dos dados pelos testes de Kolmogorov-Smirnov ou Shapiro-Wilk. Sempre que uma variável continua apresentasse distribuição dos dados 
diferente da normalidade, realizava-se transformação logarítmica dos dados e os testes para avaliação de normalidade eram novamente aplicados.

Sempre que possível, o dado com distribuição normal foi utilizado para comparação estatística, seja dos valores originais ou dos valores após transformação logarítmica.
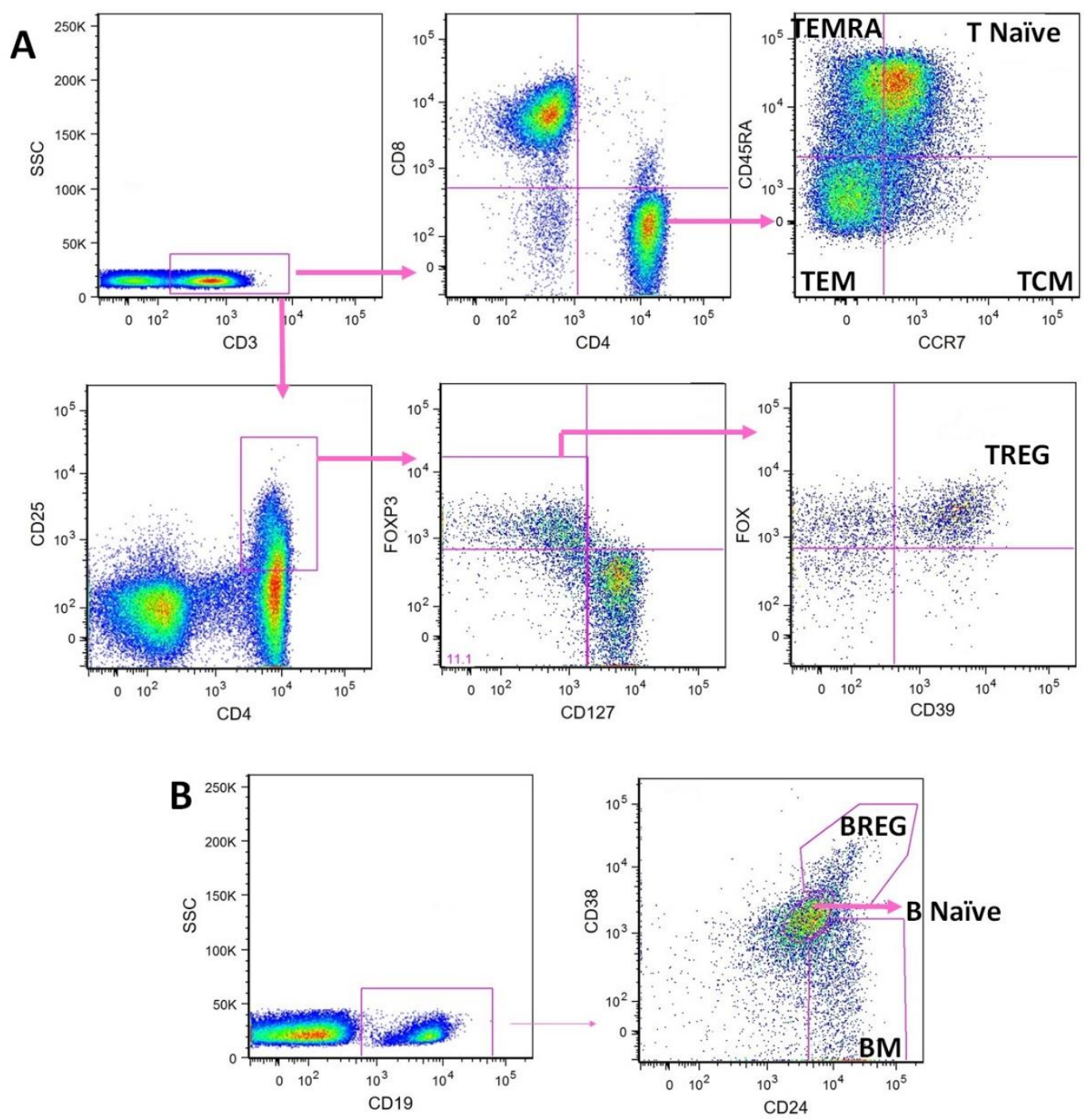

FIGURA 5. Caracterização das subpopulações de linfócitos T e B em citometria. A figura A representa a estratégia de caracterização das subpopulações $T$ e a figura $\mathbf{B}$ da caracterização de linfócitos B. TCM - Linfócito T memória central; TEM - Linfócito T memoria efetora; TEMRA - Linfócito T de memória efetora com reexpressão de RA; TREG- Linfócito T regulador; BM - Linfócito $B$ memória; BREG- Linfócito $B$ regulador. Amostra de representativa de indivíduo voluntário sadio adulto. 
Para comparação de variáveis contínuas, foram utilizados teste $t$ de Student em dados com distribuição normal e o teste de Mann-Whitney para variáveis com distribuição não-normal. Para variáveis contínuas pareadas utilizamos o teste $\mathrm{t}$ de Student pareado quando distribuição normal e teste de Wilcoxon quando distribuição não-normal.

Para avaliar interação entre diferentes variáveis utilizamos ANOVA bifatorial (two-way ANOVA).

As variáveis categóricas foram comparadas utilizando o teste de Qui quadrado ou teste exato de Fisher.

As variáveis contínuas foram apresentadas com medianas (p25-p75) e as categóricas com números absolutos (representatividade \%). 


\section{Resultados}

\subsection{Análise dos efeitos de doença renal crônica e envelhecimento}

\subsubsection{População avaliada}

Por se tratar de análise antes do transplante, foi optado por, nesta análise, referir-se aos indivíduos pré-transplante como indivíduos com doença renal crônica. Nesta análise, foram comparados 4 grupos em diferentes arranjos: voluntários adultos jovens sadios (AdS) ( $n=14)$; voluntários idosos sadios (IdS) $(n=15)$; pacientes adultos jovens com doença renal crônica (AdDRC) $(n=18)$ e pacientes idosos com doença renal crônica (IdDRC) $(n=31)$, os dois últimos grupos, admitidos para primeiro transplante renal.

Como esperado, a idade média foi menor nos adultos jovens comparado aos idosos para ambos, voluntários sadios [ $26 \pm 2$ anos vs. $79 \pm 7$ anos, $p<0,001$ ] e indivíduos com doença renal crônica [36 \pm 7 anos vs. $65 \pm 3$ anos, $p<0,001]$. Voluntários IdS eram mais velhos que os IdDRC $[79 \pm 7$ anos vs. $65 \pm 3$ anos, $p<0,001]$ e os AdDRC eram mais velhos que os voluntários AdS [36 \pm 7 anos vs. $26 \pm 2$ anos $p<0,001]$. Houve maior prevalência de gênero feminino nos voluntários IdS [93\% vs. $64 \%$ vs. $61 \%$ vs. $42 \%$, para IdS, AdS, AdDRC, IdDRC respectivamente, $p=0,01]$. Ainda dentro das expectativas, os grupos de indivíduos com doença renal crônica apresentavam maiores prevalências de hipertensão arterial sistêmica e diabetes mellitus. IdDRC e AdDRC não apresentavam diferenças nas prevalências de hipertensão arterial sistêmica, diabetes mellitus, glomerulopatias e doença renal policística autossômica dominante (tabela 2). 
Todos os indivíduos com doença renal crônica encontravam-se em terapia renal substitutiva ou apresentavam taxa de filtração glomerular estimada pela equação de CKD-EPI (do inglês, Chronic Kidney Disease Epidemiology Collaboration) inferior a $15 \mathrm{ml} / \mathrm{min} / 1,73 \mathrm{~m}^{2}$ com programação para inicio de terapia renal substitutiva.

Os grupos de indivíduos com doença renal crônica não diferiam quanto a tempo de terapia renal substitutiva, prevalência de hemodiálise, índice de massa corporal, albumina, hemoglobina e níveis de paratormônio (tabela 2).

Dados específicos do tratamento em diálise como $\mathrm{Kt} / \mathrm{V}$, duração de sessão de hemodiálise e uso de eritropoietina não foram avaliados.

Tabela 2. Dados demográficos da avaliação basal

\begin{tabular}{|c|c|c|c|c|c|}
\hline & AdS $(n=14)$ & $\operatorname{IdS}(n=15)$ & $\operatorname{AdDRC}(n=18)$ & $\operatorname{IdDRC}(n=31)$ & $P$ \\
\hline Idade (anos) & $26 \pm 2$ & $79 \pm 7^{\mathrm{a}}$ & $36 \pm 7^{b, d}$ & $65 \pm 3^{c, e, f}$ & $<0,001$ \\
\hline Gênero (masculino) n (\%) & $5(36)$ & $1(7)$ & $7(39)^{d}$ & $18(58)^{\mathrm{e}}$ & 0,01 \\
\hline IMC $\left(\mathrm{Kg} / \mathrm{m}^{2}\right)$ & --- & --- & $24(22,4-25,6)$ & $25(22,8-27,2)$ & 0,206 \\
\hline \multicolumn{6}{|l|}{ Comorbidades } \\
\hline HAS n (,\%) & 0 & 0 & $16(89)^{b, d}$ & $31(100), e$ & $<0,001$ \\
\hline Diabetes mellitus n (\%) & 0 & 0 & $3(17)$ & $15(48)^{\mathrm{c}, \mathrm{e}}$ & $<0,001$ \\
\hline Glomerulopatia n (\%) & 0 & 0 & $3(17)$ & $2(7)$ & 0,107 \\
\hline DRPAD n (\%) & 0 & 0 & $1(6)$ & $2(7)$ & 0,41 \\
\hline \multicolumn{6}{|c|}{ Dados da terapia renal substitutive } \\
\hline Tempo TRS (meses) & --- & --- & $32(14-45,5)$ & $36(21-54)$ & $0,23^{\#}$ \\
\hline TRS (HD) n (\%) & --- & --- & $17(94)$ & $28(90)$ & $1,0^{\#}$ \\
\hline \multicolumn{6}{|l|}{ Dados laboratoriais } \\
\hline Albumina & & & $4,4(4,17-4,62)$ & $4,3(3,6-4,7)$ & 0,4 \\
\hline Hemoglobina & & & $12,2(9,9-13,1)$ & $12,6(11-12,9)$ & 0,88 \\
\hline PTH & & & $236(80,5-608)$ & $237(130-574)$ & 0,868 \\
\hline \multicolumn{6}{|c|}{$\begin{array}{l}\text { AdS - Adultos jovens sadios; IdS - idosos sadios; AdDRC - adultos jovens com doença renal crônica; IdDRC - idosos com doença } \\
\text { renal crônica, IMC - indice de massa corporal, HAS - hipertensão arteral sistêmica, DRPAD - doença renal policitsica autossômica } \\
\text { dominante, TRS - terapia renal substitutiva, HD - Hemodiálise, PTH -Paratormonio. } \\
\text { \# Comparação apenas entre IdDRC e AdDRC } \\
\text { Diferença significante }(p<0,05) \text { entre: }{ }^{a} \text { AdS e IdS, }{ }^{\text {b }} \text { AdS e AdDRC },{ }^{\text {c }} \text { AdS e IdDRC, }{ }^{\text {d }} \text { IdS e AdDRC, }{ }^{\mathrm{e}} \text { IdS e IdDRC, }{ }^{\mathrm{f}} \text { AdDRC e }\end{array}$} \\
\hline
\end{tabular}




\subsubsection{Efeitos do envelhecimento nas populações linfocitárias}

\subsubsection{Indivíduos sadios}

Os efeitos do envelhecimento nos indivíduos sadios foram avaliados comparando-se os grupos de voluntários IdS e AdS. Os IdS apresentaram menores números absolutos de linfócitos totais, T, CD4 e CD8 (tabela 3, figura $6 \mathrm{~A}$ ), assim como menores números absolutos (tabela 3, figura 7A) e percentuais de linfócitos TEMRA (tabela 4, figura 7B). Apesar de os valores absolutos de linfócitos TCM e TREG não apresentarem diferença (tabela 3, figura 7A e 9A), maiores percentuais das duas populações foram observadas nos voluntários IdS (tabela 4, figura 7B e 9B). Não foram observadas diferenças nas subpopulações de linfócitos B (tabela 3 e 4, figura 8A e 8B).

\subsubsection{Indivíduos com doença renal crônica}

Para avaliar o efeito do envelhecimento nas subpopulações linfocitárias dos indivíduos com doença renal crônica foram comparados os IdDRC com os AdDRC. Os efeitos do envelhecimento nos indivíduos com doença renal crônica se assemelharam aos observados em indivíduos saudáveis. Os IdDRC apresentavam menores números absolutos de linfócitos totais, T, CD4, CD8 e B (tabela 3, figura 6A), bem como menores números absolutos de linfócitos TEM e TEMRA (tabela 3, figura 7A). Os números absolutos de linfócitos TREG não foram diferentes entre os grupos com doença renal crônica (tabela 3, figura 9A), mas os percentuais destas células entre os linfócitos TCD4 ${ }^{+} C D 25^{+}$dos IdDRC foram maiores que os dos AdDRC (tabela 4, figura 9B). Os IdDRC apresentaram, ainda, menores números absolutos de linfócitos B naive e BM (tabela 3, figura 
8A). Não foram observadas diferenças nos percentuais das subpopulações de linfócitos B entre os grupos (tabela 4, figura 8B).

\subsubsection{Efeitos da doença renal crônica nas subpopulações linfocitárias}

\subsubsection{Indivíduos adultos jovens}

Para avaliar o efeito da doença renal crônica nas subpopulações linfocitárias de adultos jovens foram comparados indivíduos AdDRC e voluntários AdS.

AdDRC apresentaram menores números absolutos de linfócitos totais, $\mathrm{T}$, CD4, CD8 e B (tabela 3, figura 6A). Dentre os linfócitos TCD4 os AdDRC apresentaram menores números absolutos de linfócitos T naive e TEMRA (tabela 3, figura 7A). Ainda, os números absolutos de linfócitos TREG não apresentaram diferença entre os grupos (tabela 3, figura 9A), mas o percentual deste fenótipo entre os linfócitos $\mathrm{CD} 4{ }^{+} \mathrm{CD} 25^{+}$foi menor entre os AdDRC (tabela 4, figura 9B). Os AdDRC também apresentaram menores números absolutos de linfócitos B naive e BM (tabela 3, figura 8A), mas sem diferenças nos percentuais das subpopulações B (tabela 4, figura 8B).

\subsubsection{Indivíduos idosos}

Para avaliar o efeito da doença renal crônica nas subpopulações linfocitárias dos indivíduos idosos foram comparados os grupos IdDRC e IdS. Os indivíduos IdDRC apresentaram menores números absolutos de linfócitos totais, T, TCD4 e B (tabela 3, figura 6A), com menores percentuais de linfócitos $B$ (tabela 4, figura 6B). Entre as células TCD4 os números absolutos de linfócitos 
T naive, TCM, TEMRA e TREG foram menores nos IdDRC (tabela 3, figura 7A e 9A). Os IdDRC apresentavam, ainda, menores percentuais de linfócitos TREG dentre as células $\mathrm{CD} 4{ }^{+} \mathrm{CD} 25^{+}$(tabela 4, figura 9B). Foram observados ainda menores números absolutos de linfócitos B naive, BM e BREG (tabela 3, figura 8A) sem diferenças em seus percentuais (tabela 4, figura 8B). 


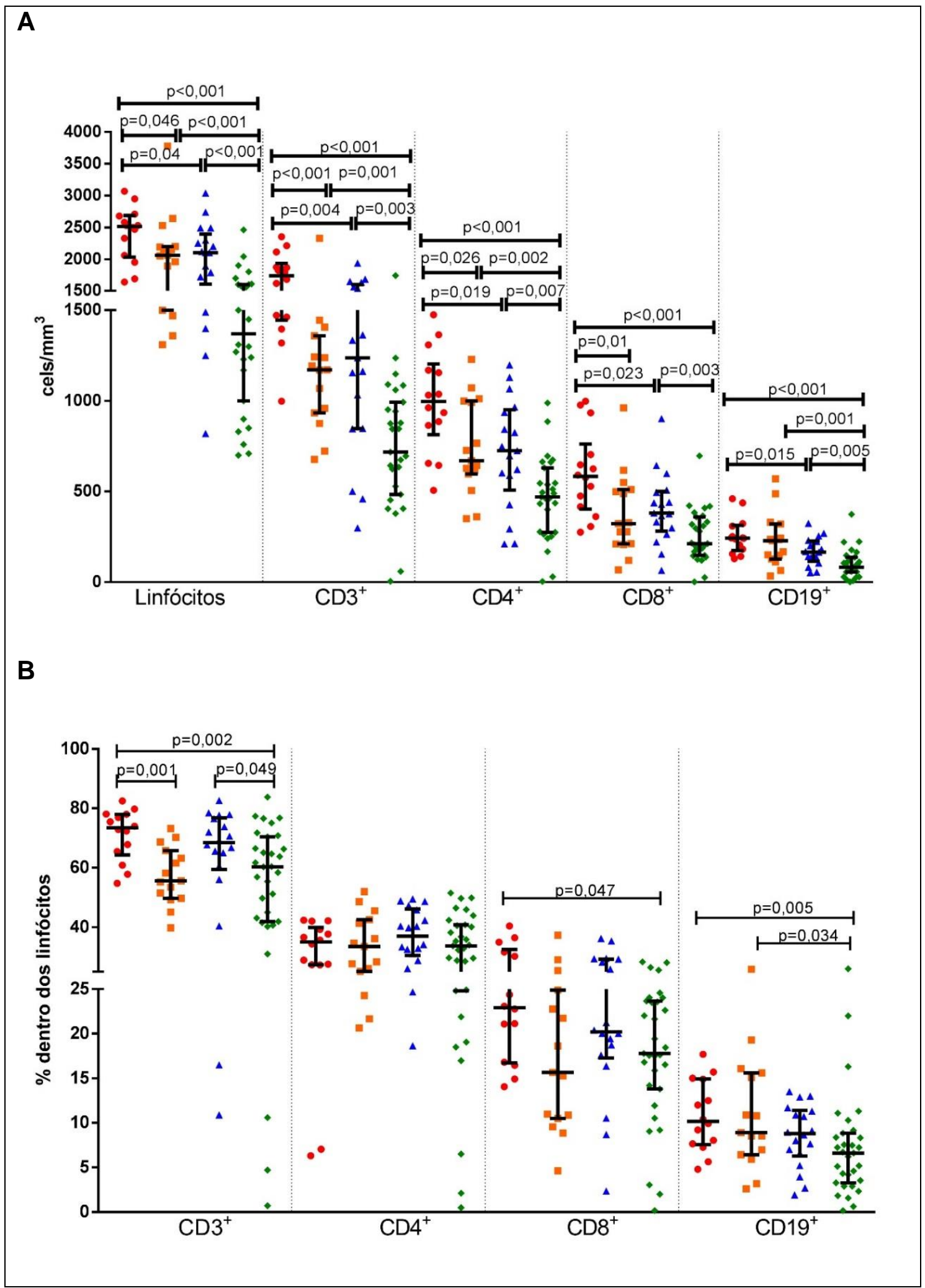

FIGURA 6. Efeitos de doença renal crônica e envelhecimento nos números (A) e percentuais (B) de linfócitos totais, linfócitos T, TCD4, TCD8 e B. Adultos jovens sadios ( $n=14)$ $(\bullet)$, idosos sadios $(n=15)(\square)$, adultos jovens com doença renal crônica $(n=18)(\boldsymbol{\Lambda})$ e idosos com doença renal crônica $(n=31)(\diamond)$. $\mathrm{CD}^{+}-$linfócitos T, CD4 ${ }^{+}-$Linfócitos T auxiliares, $\mathrm{CD}^{+}$ - Linfócitos T citotóxicos, CD19+ - linfócitos B. As barras representam a mediana e os intervalos interquartil. 


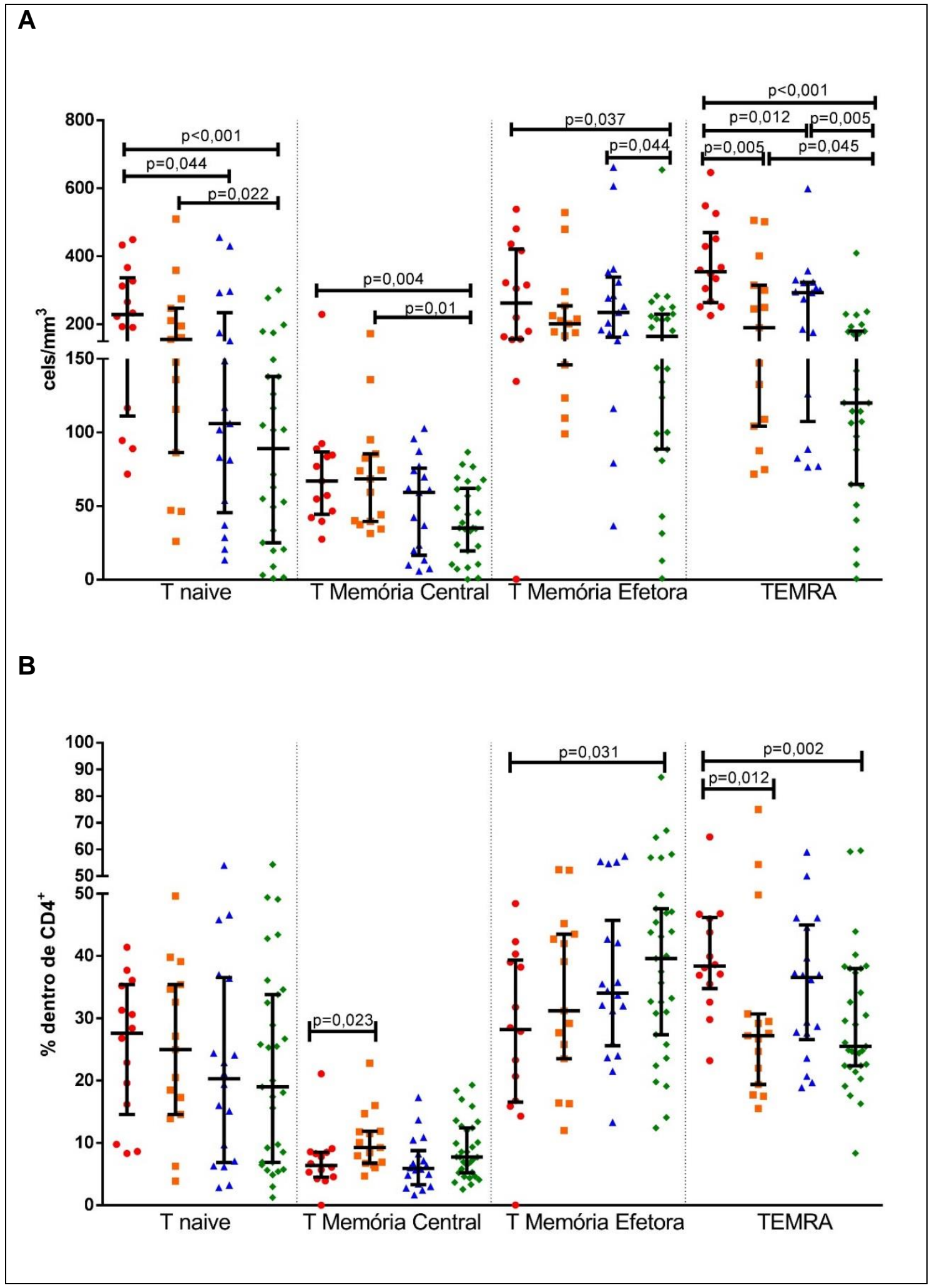

FIGURA 7. Efeitos de doença renal crônica e envelhecimento nos números (A) e percentuais (B) de linfócitos $T$ naive, T memória central, $T$ memória efetora e $T$ memoria efetora com reexpressão de RA. Adultos jovens sadios $(n=14)(\bullet)$, idosos sadios $(n=15)(\square)$, adultos jovens com doença renal crônica $(n=18)(\Delta)$ e idosos com doença renal crônica $(n=31)$ $(\diamond)$. TEMRA - T memoria efetora com reexpressão de RA. As barras representam a mediana e os intervalos interquartil. 


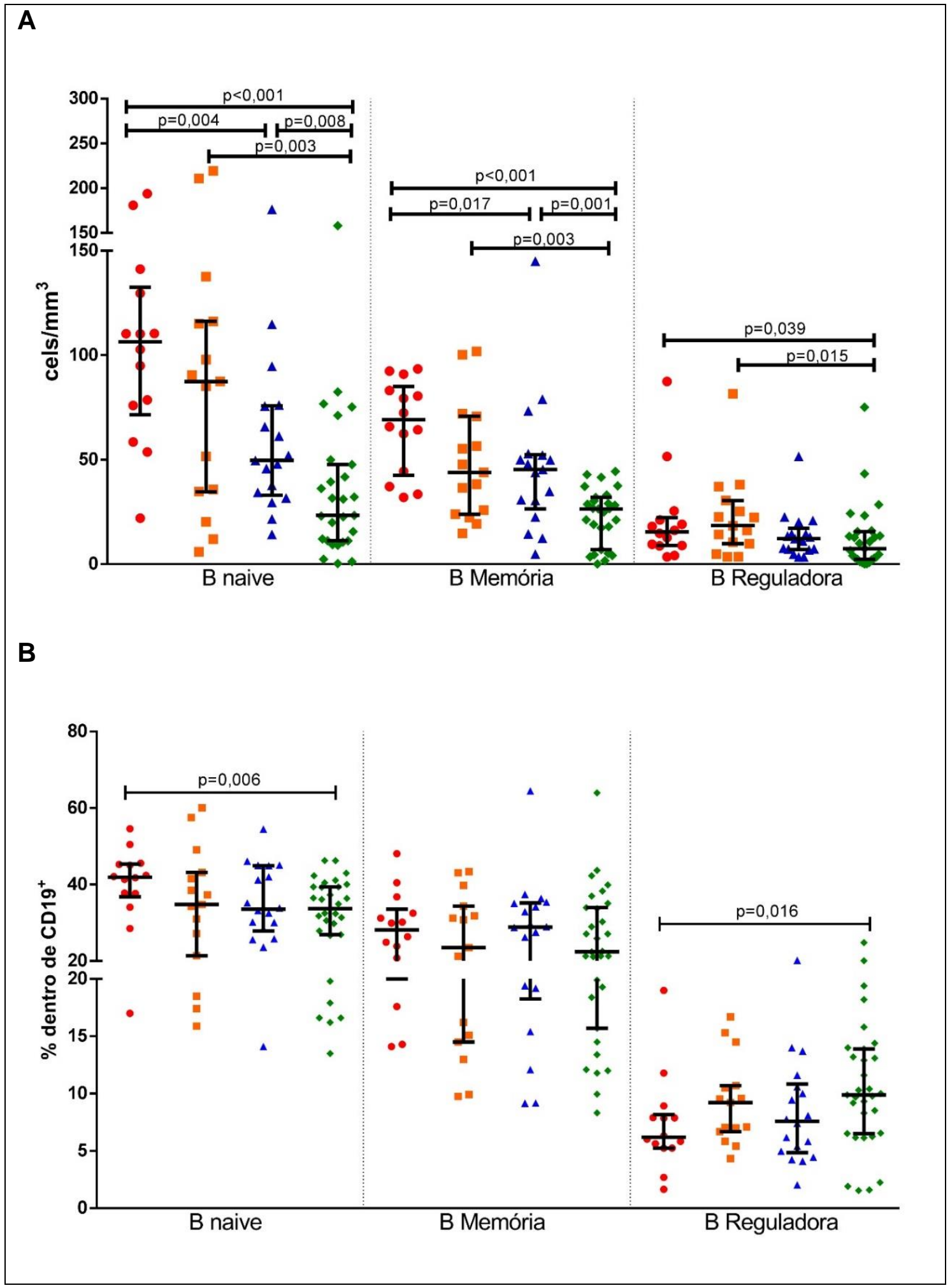

FIGURA 8. Efeitos de doença renal crônica e envelhecimento nos números $(A)$ e percentuais $(B)$ de linfócitos $B$ naive, $B$ memória e $B$ reguladores. Adultos jovens sadios $(n=14)$ $(O)$, idosos sadios $(n=15)(\square)$, adultos jovens com doença renal crônica $(n=18)(\Delta)$ e idosos com doença renal crônica $(n=31)(\diamond)$. As barras representam a mediana e os intervalos interquartil. 


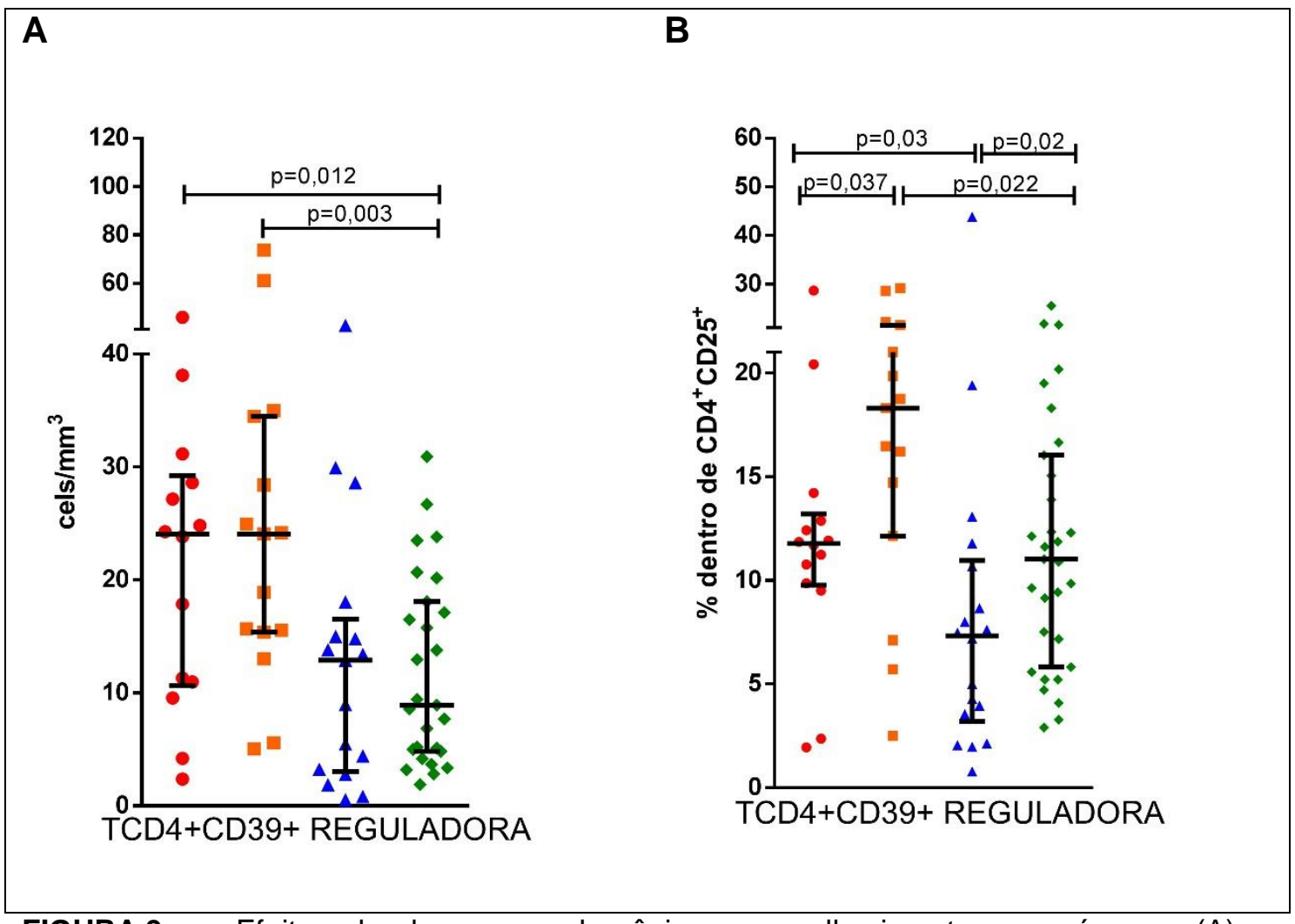

FIGURA 9. Efeitos de doença renal crônica e envelhecimento nos números (A) e percentuais (B) de linfócitos T reguladores. Adultos jovens sadios $(n=14)(\bullet)$, idosos sadios $(n=15)(\square)$, adultos jovens com doença renal crônica $(n=18)(\Delta)$ e idosos com doença renal crônica $(n=31)(\diamond)$. As barras representam a mediana e os intervalos interquartil. 


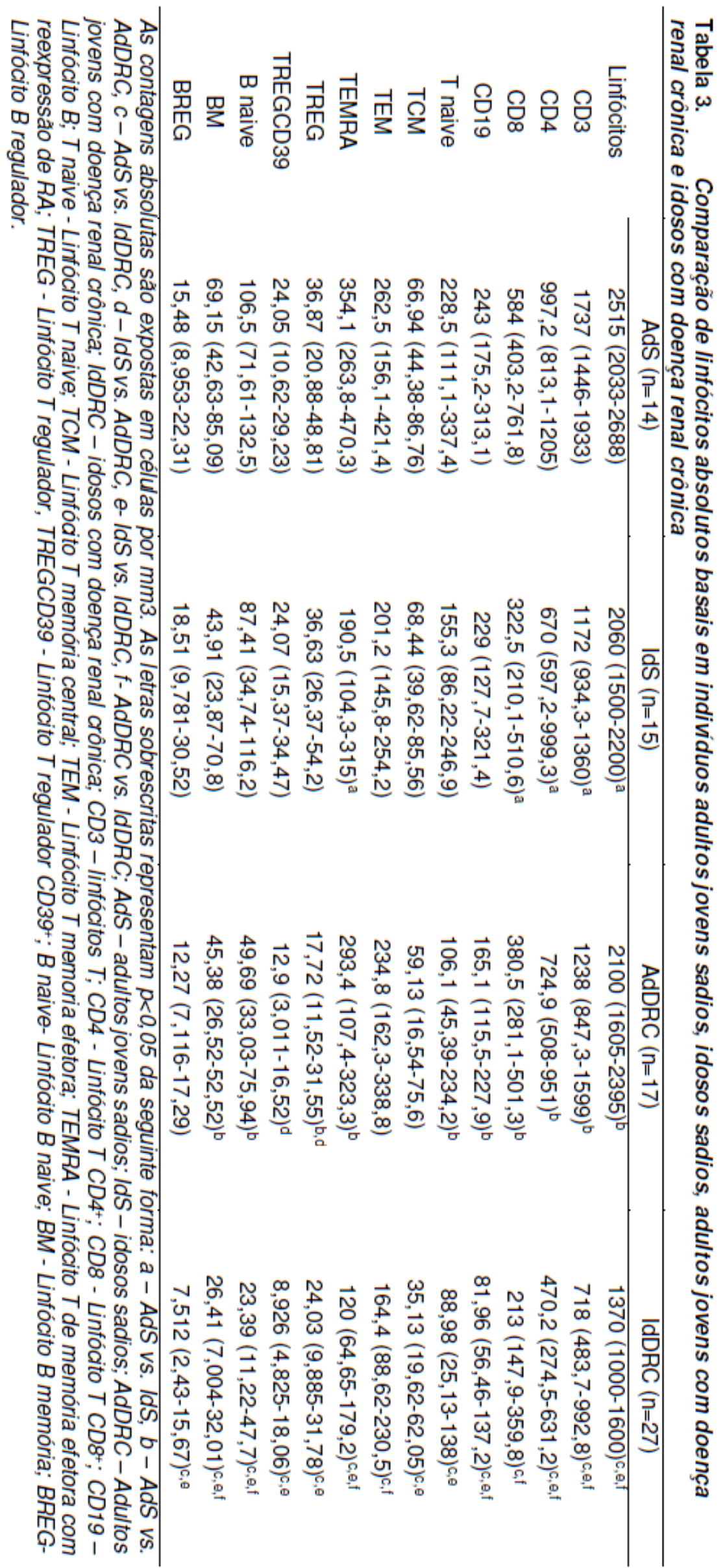




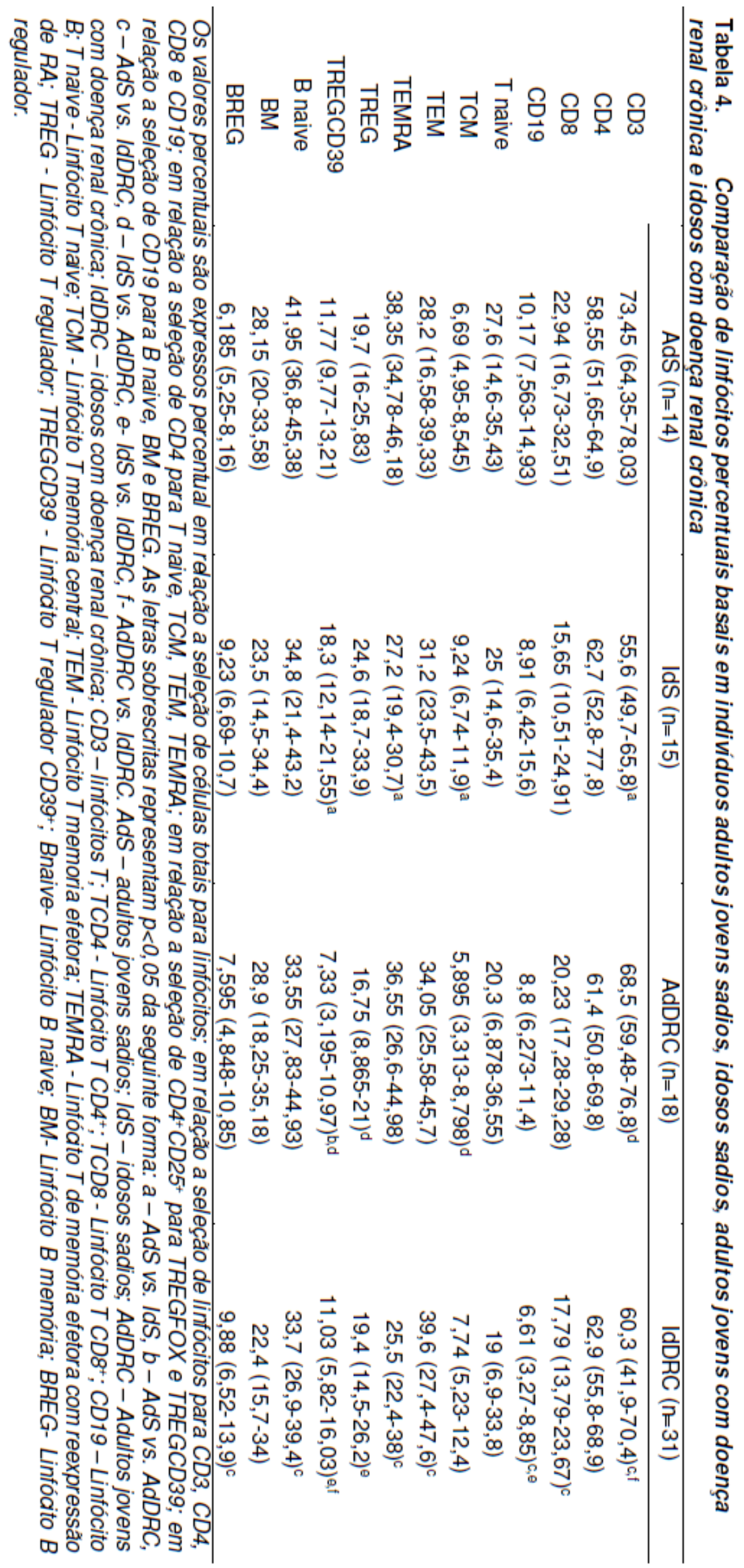




\subsubsection{A interação de envelhecimento e doença renal crônica nas} populações linfocitárias

O efeito da ocorrência concomitante de envelhecimento e doença renal crônica nas subpopulações linfocitárias foi avaliado por comparação de pacientes IdDRC e voluntários AdS. Os IdDRC apresentaram menores números absolutos de linfócitos totais e de todas as subpopulações linfocitárias, T, B, CD4, CD8, T naive, TCM, TEM, TEMRA, TREG, B naive, BM e BREG (tabela 3, figura 6A, 7A, 8A, 9A).

IdDRC apresentaram menores percentuais de linfócitos T, CD8, TEMRA, B e B naive (tabela 4, figura 6B,7B,8B). Apesar de apresentarem menores números absolutos de linfócitos de maneira geral, os IdDRC apresentaram maiores percentuais de linfócitos TEM e BREG (tabela 4, figura 7B, 8B). Os percentuais de linfócitos TREG não diferiram entre os dois grupos (tabela 4, figura 9B).

No objetivo de avaliar os efeitos combinados de envelhecimento e doença renal crônica, além do possível efeito sinérgico destas condições, foi realizada a análise de variância de dupla classificação (two-way ANOVA) considerando os 4 grupos conjuntamente. As variáveis independentes analisadas foram envelhecimento e doença renal crônica.

Consideramos como alterações nas subpopulações linfocitárias atribuíveis a doença renal crônica aquelas que foram encontradas simultaneamente nas análises pareadas (AdS vs. AdDRC e IdS vs. IdDRC). De maneira semelhante, foram atribuídas ao envelhecimento mudanças que também ocorressem simultaneamente nas análises pareadas (AdS vs. IdS e AdDRC vs. IdDRC). Diferenças apresentadas apenas na análise de variância (two-way ANOVA) também foram consideradas relevantes. 
Todas as diferenças encontradas nas análises dos controles pareados dos efeitos do envelhecimento e da doença renal crônica foram também observadas na análise de variância (two-way ANOVA). Não foi observado efeito sinérgico de envelhecimento e doença renal crônica nos números absolutos ou valores percentuais das diferentes subpopulações linfocitárias (tabela 5). Na análise da variância, mais uma vez, foi observado efeito do envelhecimento e da doença renal crônica sobre os percentuais de linfócitos TREGs, mas com mudanças opostas em seus valores. $O$ envelhecimento resultou em maiores valores percentuais de linfócitos TREG, enquanto a doença renal crônica em menores valores percentuais de linfócitos TREGs.

$\mathrm{Na}$ análise de variância, foi possível documentar novas diferenças atribuíveis ao envelhecimento e à doença renal crônica não detectadas nas análises anteriores. Envelhecimento se associou a menores números absolutos de linfócitos T naive e BM, com menores percentuais de linfócitos TCD8 e TEMRA, além de maiores percentuais de linfócitos TCM. Pacientes com doença renal crônica apresentaram menores números absolutos de linfócitos T naive, TCM, BM and BREG, associado a menores percentuais de linfócitos B e maiores percentuais de linfócitos TEM (tabela 5). 
Tabela 5. Análise de variância (ANOVA) bifatorial para DRC, idade e interação idadexDRC

\begin{tabular}{|c|c|c|c|c|c|c|}
\hline & \multicolumn{3}{|c|}{ Absolutos } & \multicolumn{3}{|c|}{ Percentuais } \\
\hline & Idade $^{a}$ & DRC & $\begin{array}{l}\text { Idade } x \\
\text { DRC }^{b}\end{array}$ & Idade $^{a}$ & DRC & $\begin{array}{l}\text { Idadex } \\
\text { DRC }^{b}\end{array}$ \\
\hline $\begin{array}{l}\text { Linfócitos totais } \\
\text { Subpopulacão: }\end{array}$ & $<0,001$ & $<0,001$ & 0,2 & --- & --- & --- \\
\hline$T$ & $<0.001$ & $<0.001$ & 0.64 & 0.009 & 0,17 & 0,51 \\
\hline TCD4 & $<0,001$ & $<0,001$ & 0,95 & 0,18 & 1,0 & 0,62 \\
\hline T CD8 & $<0,001$ & 0,001 & 0,45 & 0,007 & 0,41 & 0,41 \\
\hline B & 0,06 & $<0,001$ & 0,38 & 0,65 & 0,02 & 0,53 \\
\hline$T$ naive & 0,04 & 0,003 & 0,96 & 0,95 & 0,34 & 0,95 \\
\hline TCM & 0,41 & 0,001 & 0,76 & 0,02 & 0,39 & 0,62 \\
\hline TEM & 0,054 & 0,37 & 0,53 & 0,19 & 0,03 & 0,79 \\
\hline TEMRA & $<0,001$ & $<0,001$ & 0,55 & 0,02 & 0,26 & 0,56 \\
\hline TREG & 0,52 & $<0,001$ & 0,35 & 0,04 & 0,02 & 0,54 \\
\hline$B$ naive & 0,06 & $<0,001$ & 0,69 & 0,12 & 0,11 & 0,64 \\
\hline BM & 0,001 & $<0,001$ & 0,61 & 0,38 & 0,96 & 0,94 \\
\hline BREG & 0,98 & 0,04 & 0,79 & 0,07 & 0,32 & 0,94 \\
\hline
\end{tabular}

DRC - doença renal crônica, TCM - linfócito T memória central, TEM - Linfócito T de memória efetora, TEMRA - memória T efetora com reexpressão de RA, TREG - Linfócitos T reguladores, BM - linfócitos B memória, BREG - linfócitos B reguladores. Os valores de $p$ são apresentados para cada variável analisada. $\mathrm{P}<0,05$ foi considerado significante.

a As categorias etárias de adultos (18-45 anos) e idosos (>60 anos) foram utilizadas

b Interação entre idade e DRC no modelo estatístico

\subsection{Avaliação dos efeitos da timoglobulina e conversão para} everolimo na população idosa transplantada renal

\subsubsection{Demografia da população analisada}

Nesta análise, foram avaliados os efeitos da indução com ATG e da conversão precoce para everolimo nas subpopulações de linfócitos periféricos de pacientes idosos. Para esta análise comparamos 3 grupos: a- adultos jovens receptores de transplante renal com imunossupressão padrão (AdISP) (PRED+TAC+MPS) $(n=20)$, b- idosos receptores de transplante renal com imunossupressão padrão (IdISP) ( $n=19)$ e c- idosos receptores de transplante renal com conversão precoce para everolimo (IdCEv) ( $n=16)$. Os pacientes idosos foram randomizados nos grupos de imunossupressão padrão ou conversão precoce para everolimo no momento da inclusão. Os pacientes idosos antes da conversão recebiam imunossupressão padrão. Assim, todos os pacientes idosos foram considerados em conjunto antes da conversão para everolimo. 
Todos os pacientes incluídos na análise dos efeitos de envelhecimento e doença renal crônica foram incluídos nesta fase da avaliação de imunossupressores, 18 indivíduos no grupo AdISP, 16 no grupo IdISP, 15 no grupo IdCEv. Houve ainda inclusão de 2 indivíduos no grupo AdISP e 3 no grupo IdISP, não avaliados previamente por material biológico insuficiente para análise, e 1 indivíduo no grupo IdCEv não avaliado previamente por não ter realizado coleta de amostra na situação basal.

Os AdISP eram mais jovens que os dois grupos de idosos (36 \pm 7 vs. $65 \pm 3$, p $<0,0001$ e vs. $65 \pm 3$ anos, $p<0,0001$ ), enquanto os grupos de idosos não diferiam quanto à idade. Os grupos não diferiam também quanto a gênero, prevalência de hipertensão arterial sistêmica ou diabetes mellitus. Hemodiálise foi a modalidade de terapia renal substitutiva mais comum e o tempo médio de terapia renal susbtitutiva foi semelhante entre os grupos de AdISP, IdISP e IdCEv (30,5 vs. 38 vs. 33,5 meses, $\mathrm{p}=0,06)$. O número de disparidades HLA e o maior valor de reatividade contra painel (classes 1 e 2) também foi semelhante entre os grupos. Os idosos receberam com maior frequência transplante de doador falecido ( 45 vs. $100, p<0,0001$ e vs. $87,5 \%$, $p<0,0001)$. Dentre os doadores falecidos, o percentual de doadores com critério expandido foi maior nos dois grupos de idosos, mas sem diferença estatística entre os grupos (22,2 vs. 57,9 vs. $42,9 \%$, AdISP, IdISP e IdCEv, respectivamente, AdISP vs. IdISP $p=0,07$, AdISP vs. IdCEv $p=0,3$, IdISP vs. IdCEv $p=0,6$ ), assim como o tempo de isquemia fria (24 vs. 26 . vs. 24 horas, AdISP, IdISP e IdCEv, respectivamente, $p=0,44$ ) (tabela 6 ).

O grupo AdISP possuía 20, 17 e 7 amostras coletadas nos dias 0, 30 e 365 respectivamente. O grupo IdISP possuía 34, 33 e 5 amostras coletadas nos dias 0, 30 e 365 respectivamente. $O$ grupo IdCEv possuia 14 e 5 amostras coletadas nos dias 
60 e 365 respectivamente. As amostras programadas para coleta nos tempos $30 \mathrm{~d}$ e $365 d$ foram coletadas com $32 \pm 7 d$ e $386 \pm 82 d$, enquanto a amostra de $60 d$ foi coletada com $32 \pm 4 d$ da conversão para EVL. Todos os receptores idosos encontravam-se em imunossupressão padrão nos dias 0 e 30. 
Tabela 6. Características dos receptores agrupados por idade e imunossupressão

\begin{tabular}{lccc}
\hline Características & AdISP $(\mathrm{n}=20)$ & IdISP $(\mathrm{n}=19)$ & IdCEv $(\mathrm{n}=16)$ \\
\hline Idade & $36 \pm 7$ & $65 \pm 3^{\mathrm{a}}$ & $65 \pm 3^{\mathrm{b}}$ \\
Gênero masculino $\mathrm{n}(\%)$ & $8(40)$ & $10(52,6)$ & $10(62,5)$ \\
Comorbidades $\mathrm{n}(\%)$ & & & \\
$\quad$ HAS & $18(90)$ & $19(100)$ & $16(100)$ \\
$\quad$ DM & $4(20)$ & $11(57,9)$ & $6(37,5)$ \\
Doença de base n (\%) & & & \\
$\quad$ Nefropatia diabética & $3(15)$ & $10(52,6)$ & $4(25)$ \\
Doença vascular & $1(5)$ & $5(26,3)$ & $4(25)$ \\
Glomerulopatia & $3(15)$ & $1(5,3)$ & $1(6,2)$ \\
DRPAD & $1(5)$ & $1(5,3)$ & $1(6,2)$ \\
Outras & $12(60)$ & $2(10,5)$ & $6(37,5)$ \\
HD n (\%) & $19(95)$ & $16(84,2)$ & $16(100)$ \\
Tempo de TRS (meses) & $30,5(14-39,25)$ & $38(21-54)$ & $33,5(20,75-49,75)$ \\
PRA & $0(0-0)$ & $26(10,5-43)$ & $18(5,75-39,25)$ \\
Disparidades HLA & $4(3-4,75)$ & $2(2-4)$ & $3(2-3,75)$ \\
Doador falecido $n$ (\%) & $9(45)$ & $19(100)^{\mathrm{a}}$ & $14(87,5)^{\mathrm{b}}$ \\
Doador de critério expandido $\mathrm{n}(\%)$ & $2(22,2)$ & $11(57,9)$ & $6(42,9)$ \\
Tempo de isquemia fria (horas) & $24(22-33,5)$ & $26(21-28)$ & $24(21,5-27,5)$ \\
\hline
\end{tabular}

AdISP - Adultos jovens com imunossupressão padrão, IdISP - idosos com imunossupressão padrão, IdCEv- Idosos com conversão para everolimo, $\mathrm{n}$ - número, HAS - Hipertensão arterial sistêmica, DM - diabetes mellitus, DRPAD - doença renal policística autossômica dominante, HD - hemodiálise, TRS - terapia renal substitutiva, PRA - reatividade a painel calculado, HLA - do inglês Human leukocyte antigen.

Diferenças significativas entre: ${ }^{a}$ AdISP vs. IdISP; b AdISP vs. IdCEv.

\subsubsection{Linfócitos totais e subpopulações de linfócitos $T$}

Os AdISP apresentaram maiores números absolutos de linfócitos totais antes do transplante [2100(1630-2400) vs. 1310(1000-1600), $p<0,0001]$, e com 30 dias de transplante [1960(1270-2970) vs. $910(700-1198), p<0,0001]$ comparado aos IdISP (tabela 7, figura 10). Com um ano de seguimento os AdISP comparados aos IdISP apresentavam maiores números absolutos de linfócitos totais [1850(1590-2120) vs. 1130(460-1325), $p=0,018]$, mas não apresentavam diferenças em comparação aos IdCEv [vs. 1410(850-1895), $p=0$,268] (tabela 7, figura 10). Ainda, IdISP apresentaram redução do número de linfócitos totais com 30 dias do transplante [1310(1000-16000) 
vs. 910 (700-11980), $p=0,0012]$, mas, na comparação de 365 dias e basal, não havia diferença no número de linfócitos totais no grupo IdISP [1130(460-1325), $p=0,0,625]$ e no de IdCEv [1410(805-1895), p>0,9999] (tabela 7, figura 10).

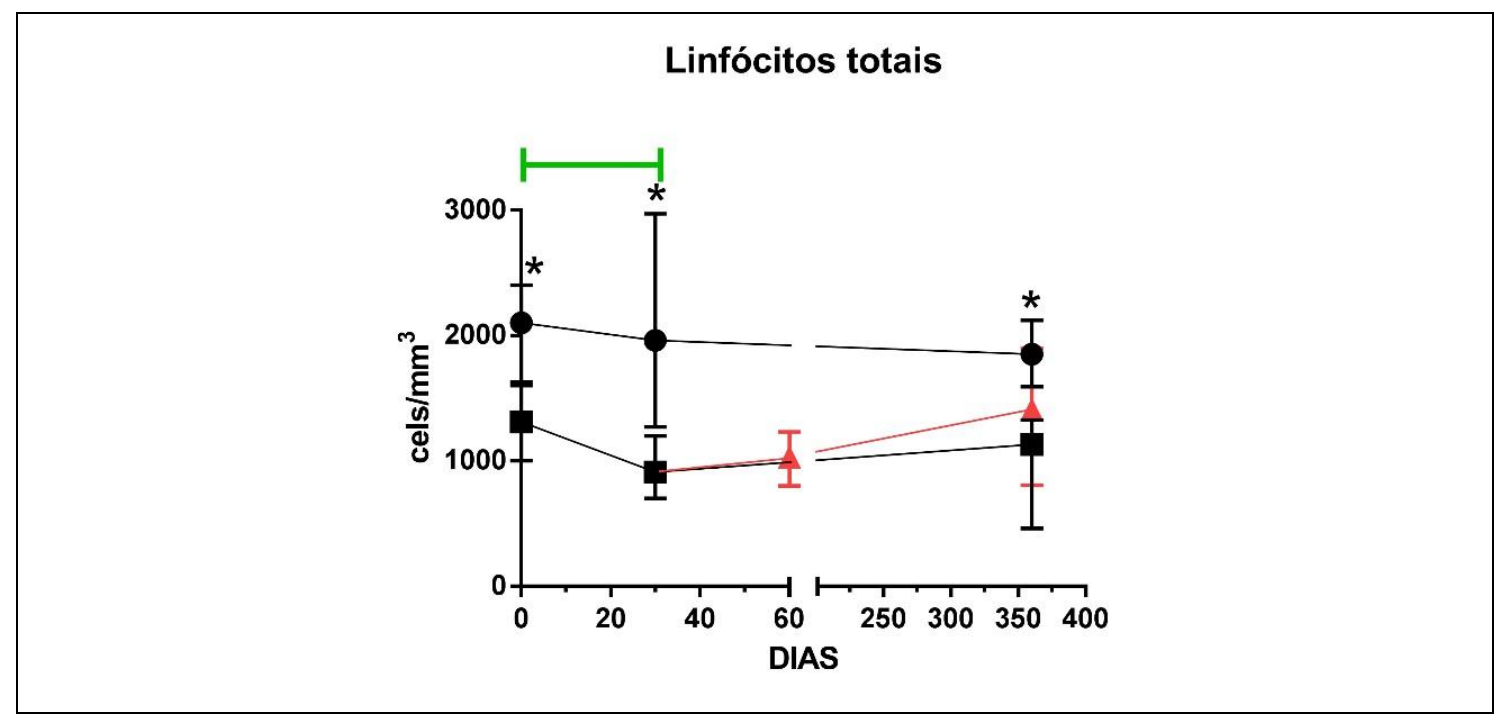

FIGURA 10. Comparação durante 1 ano dos grupos de AdISP $(\bullet)$ vs. IdISP (ロ) vs. IdCEv (A) quanto ao número de linfócitos totais. AdISP - adultos jovens transplantados renais com imunossupressão padrão, IdISP - idosos transplantados renais com imnunossupressão padrão, IdCEv - idosos transplantados renais convertidos para everolimo.

* Diferenças estatísticas $(p<0,05)$ na comparação de AdISP vs. IdISP.

A linha continua verde se refere a diferença no grupo IdISP em diferentes tempos.

As mesmas variações intragrupo e intergrupo nos números absolutos de linfócitos totais também estavam presentes nos linfócitos T e TCD4 (tabela 7, figura 11A e 11C). A ocorrência de mesmas alterações nos números absolutos dos linfócitos totais, T e TCD4 sugerem maior relevância nas variações de linfócitos TCD4 nas contagens linfocitárias.

Os números absolutos de linfócitos TCD8 foram maiores nos AdISP comparado aos IdISP antes do transplante e com 30 dias de transplante. Com um ano de transplante os AdISP apresentavam maiores números absolutos de linfócitos TCD8 comparado aos IdISP, mas semelhantes aos IdCEv. Nenhum dos grupos apresentou variações dos números de linfócitos TCD8 ao longo do tempo (tabela 7, figura 11E). 
Apesar das mudanças nos números absolutos de linfócitos T e TCD4, apenas os linfócitos T apresentavam maiores percentuais nos AdISP comparado aos IdISP antes do transplante, sem outras diferenças entre os grupos ao longo do tempo (tabela 8, figura 11B e 11D). Os percentuais de linfócitos T e TCD4 também não apresentaram oscilações em cada grupo ao longo do tempo (tabela 8, figura 11B e 11D). Os AdISP apresentaram elevação do percentual de linfócitos TCD8 com 1 ano comparado a situação pré-transplante (tabela 8, figura 11F). Aos 30 dias os AdISP apresentavam maiores percentuais de linfócitos TCD8 comparado aos IdISP, mas, esta diferença não foi encontrada em outros períodos avaliados (tabela 8, figura 11F). 


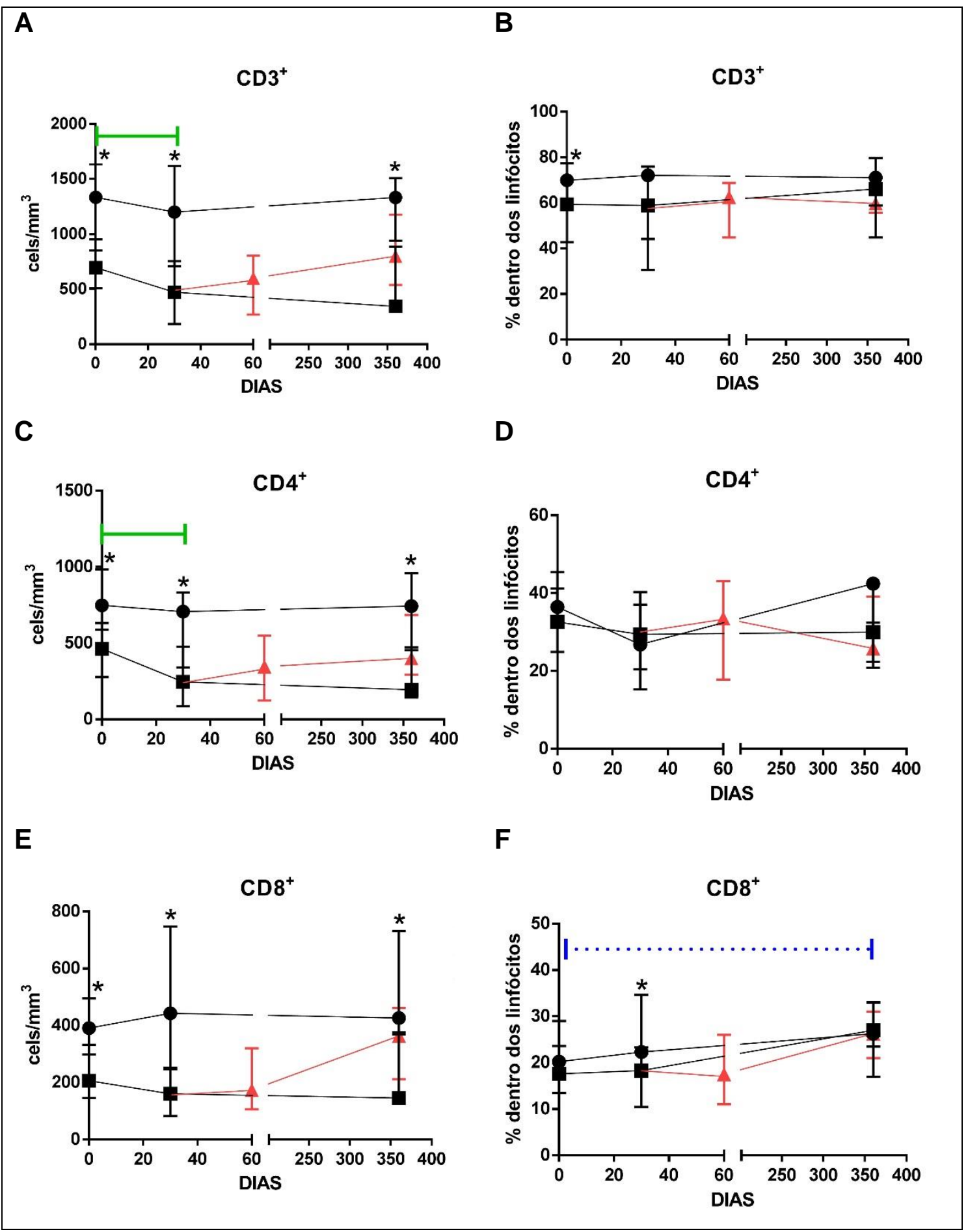

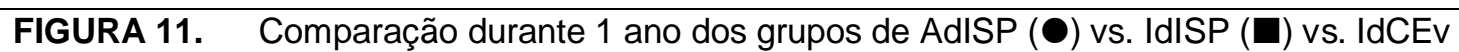
( $\Delta$ ) quanto ao número de linfócitos $\mathrm{T}(\mathrm{A}), \mathrm{T} \mathrm{CD4}^{+}(\mathrm{C})$ e $\mathrm{T} \mathrm{CD}^{+}(\mathrm{E})$, e ainda, percentuais de linfócitos $\mathrm{T}(\mathrm{B}), \mathrm{T} \mathrm{CD}^{+}(\mathrm{D})$ e $\mathrm{T} \mathrm{CD8} 8^{+}(\mathrm{F})$. AdISP - adultos jovens transplantados renais com imunossupressão padrão, IdISP - idosos transplantados renais com imnunossupressão padrão, IdCEv - idosos transplantados renais convertidos para everolimo, $\mathrm{CD}^{+}$- linfócitos $\mathrm{T}$, CD4+- linfócitos T auxiliadores, $\mathrm{CD}^{*+}$ - Linfócitos T citotóxicos,

* Diferenças estatísticas $(p<0,05)$ na comparação de AdISP vs. IdISP.

A linha pontilhada azul se refere a diferenças no grupo de AdISP em diferentes tempos. As linhas continuas verdes se referem a diferenças no grupo IdISP em diferentes tempos. 
Os AdISP apresentavam, antes do transplante, maior número de linfócitos $\mathrm{B}$ que os IdISP [165 (106-225) vs. 76 (51-137), p=0,005] e com 30 dias de transplante esta diferença ainda persistia [276 (143-430) vs. 101 (58-177), $p=0,002$ ], mas, com 1 ano do trasnsplante os AdISP, IdISP e IdCEv não apresentavam diferenças no número de linfócitos B [129 (107-381) vs. 41 (29-110) vs. 78 (56-189), repectivamente] (tabela 7, figura 12A). Os AdISP apresentaram elevação transitória no número de linfócitos $B$ com 30 dias do transplante (tabela 7, figura 12A). Ao longo do período de transplante avaliado, AdISP e idosos de ambos os grupos não apresentavam diferenças nos percentuais de linfócitos B (tabela 8, figura 12B). Entratanto, AdISP e IdISP apresentaram elevação transitória do percentual de linfócitos B com 30 dias de transplante (tabela 8 , figura 12B).

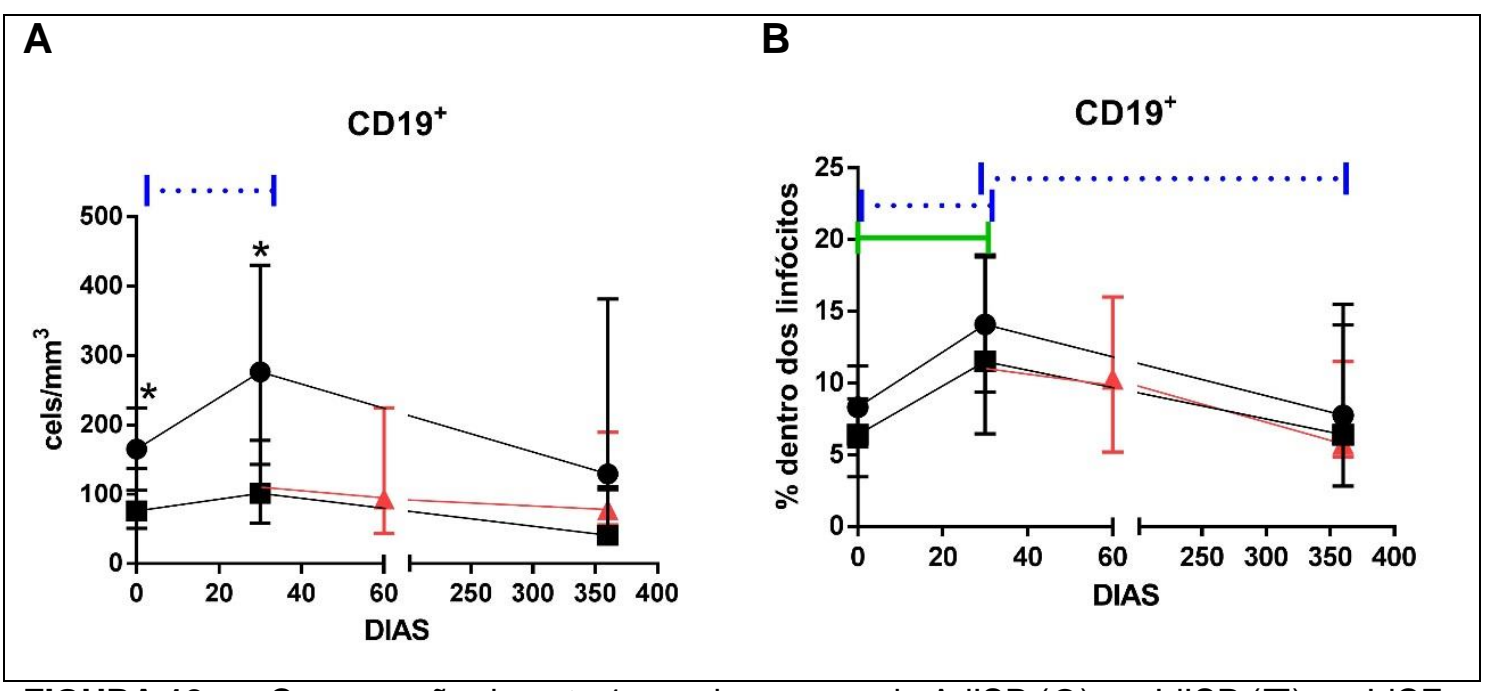

FIGURA 12. Comparação durante 1 ano dos grupos de AdISP $(\bullet)$ vs. IdISP $(\mathbf{\square})$ vs. IdCEv (A) quanto ao número $(A)$ e percentual de linfócitos B. AdISP - adultos jovens transplantados renais com imunossupressão padrão, IdISP - idosos transplantados renais com imnunossupressão padrão, IdCEv - idosos transplantados renais convertidos para everolimo. * Diferenças estatísticas $(p<0,05)$ na comparação de AdISP vs. IdISP.

As linhas pontilhadas azuis se referem a diferenças no grupo de AdISP em diferentes tempos. A linha continua verde se refere a diferenças no grupo IdISP em diferentes tempos. 


\subsubsection{Linfócitos TCD4 naive e memória}

Os números absolutos de linfócitos TCM apresentaram apenas variações dicretas (tabela 7, figura 13B). As variações nos números absolutos dos linfócitos $T$ naive, TEM e TEMRA foram semelhantes as ocorridas nos números absolutos dos

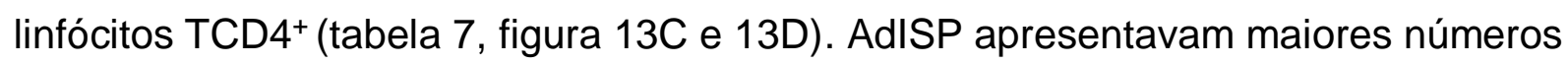
absolutos de linfócitos T naive, TEM e TEMRA comparado ao grupo de IdISP na situação basal e com 30 dias do transplante, esta diferença se mantinha com 1 ano para linfócitos TEM e TEMRA entre AdISP e IdISP (tabela 7, figura 13A, 13C, 13D). Ao completar 1 ano não havia diferenças nos números de linfócitos TEM e TEMRA comparando AdISP e IdCEv, ou grupo IdISP com IdCEv (tabela 7, figura 13C e 13D). Ainda, com 1 ano, os números de linfócitos $T$ naive não apresentavam qualquer diferença na comparação entre os 3 grupos (tabela 7, figura 13A). AdISP e IdISP apresentaram, com 30 dias do transplante, uma redução transitória nos números absolutos de linfócitos TEM (tabela 7, figura 13C). 


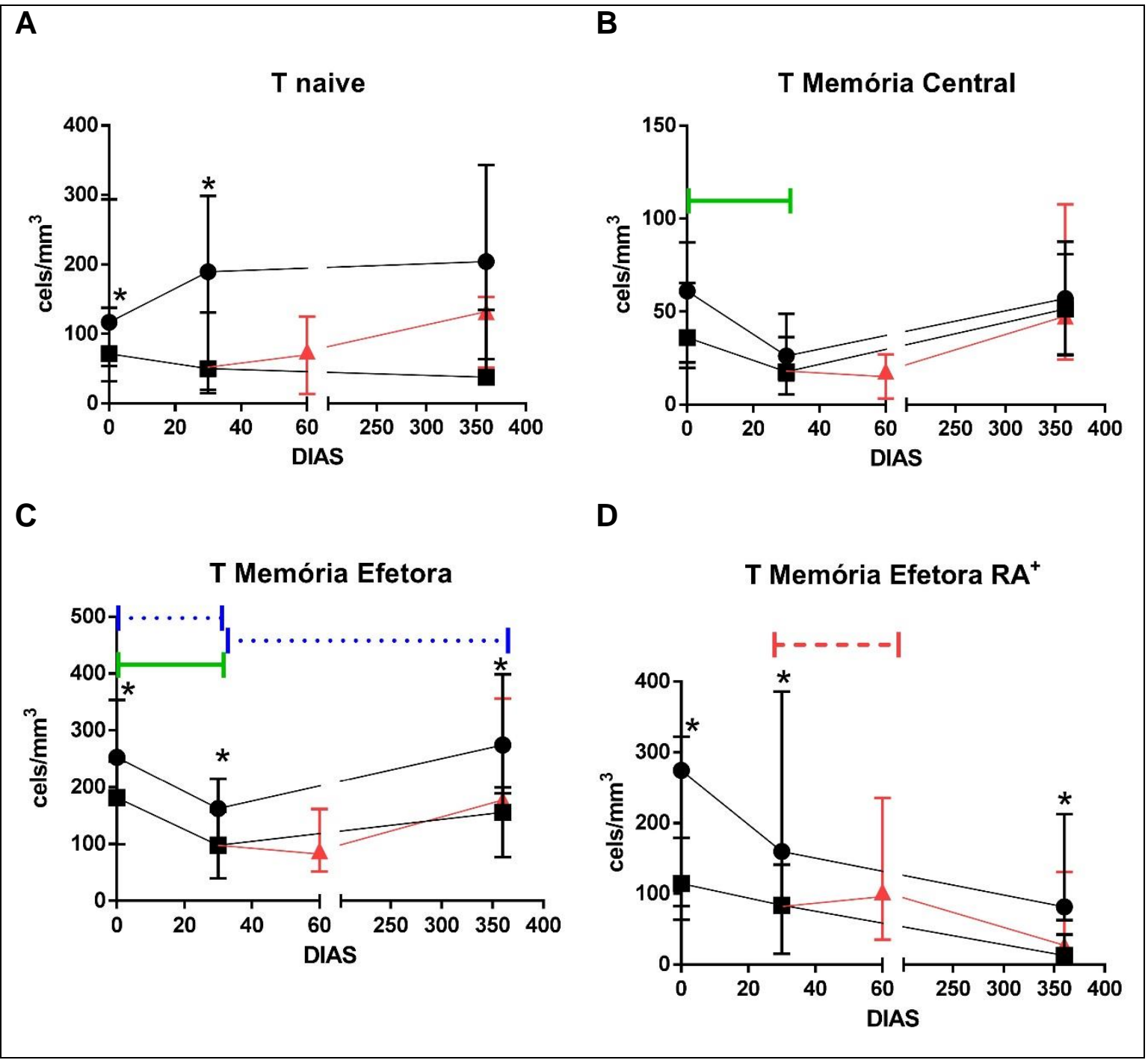

FIGURA 13. Comparação durante 1 ano dos grupos de $\operatorname{AdISP}(\bullet)$ vs. IdISP $(\mathbf{\square})$ vs. IdCEv ( $(\mathbf{\Delta})$ quanto ao número de linfócitos $T$ naive $(A)$, Tmemória central (B), T memória efetora (C) e T memória efetora $\mathrm{RA}^{+}(\mathrm{D})$. AdISP - adultos jovens transplantados renais com imunossupressão padrão, IdISP - idosos transplantados renais com imnunossupressão padrão, IdCEv - idosos transplantados renais convertidos para everolimo.

* Diferenças estatísticas $(p<0,05)$ na comparação de AdISP vs. IdISP.

As linhas pontilhadas azuis se referem a diferenças no grupo de AdISP em diferentes tempos. As linhas continuas verdes se referem a diferenças no grupo IdISP em diferentes tempos. A linha interrompida vermelha se refere a diferenças no grupo IdCEv em diferentes tempos.

Os percentuais das subpopulações de linfócitos $T$ apresentaram mudanças mais evidentes nos linfócitos TCM (tabela 8, figura 14B). Os percentuais de linfócitos T naive não apresentaram diferenças entre os grupos nos vários pontos analisados, bem como não variaram em cada grupo ao longo do tempo (tabela 8, figura 14A). 0 percentual dos linfócitos TEM e TEMRA não apresentaram variações ao longo do tempo em cada grupo (tabela 8, figura 14C e 14D). Aos 30 dias, IdISP apresentavam 
maiores percentuais de linfócitos TEM que os AdISP. Por outro lado, com um ano, os AdISP apresentavam maiores percentuais de linfócitos TEMRA comparativamente a IdISP (tabela 8, figura 14C e 14D). Os percentuais dos linfócitos TCM apresentaram queda transitória com 30 dias, tanto para AdISP como para IdISP, alteração mantida com 60 dias na análise de IdCEv (tabela 8, figura 14B). Os percentuais de linfócitos TCM antes do transplante eram semelhantes para AdISP e IdISP, mas, em um ano os IdISP apresentavam maiores percentuais de linfócitos TCM comparados a população AdISP (tabela 8, figura 14B). 


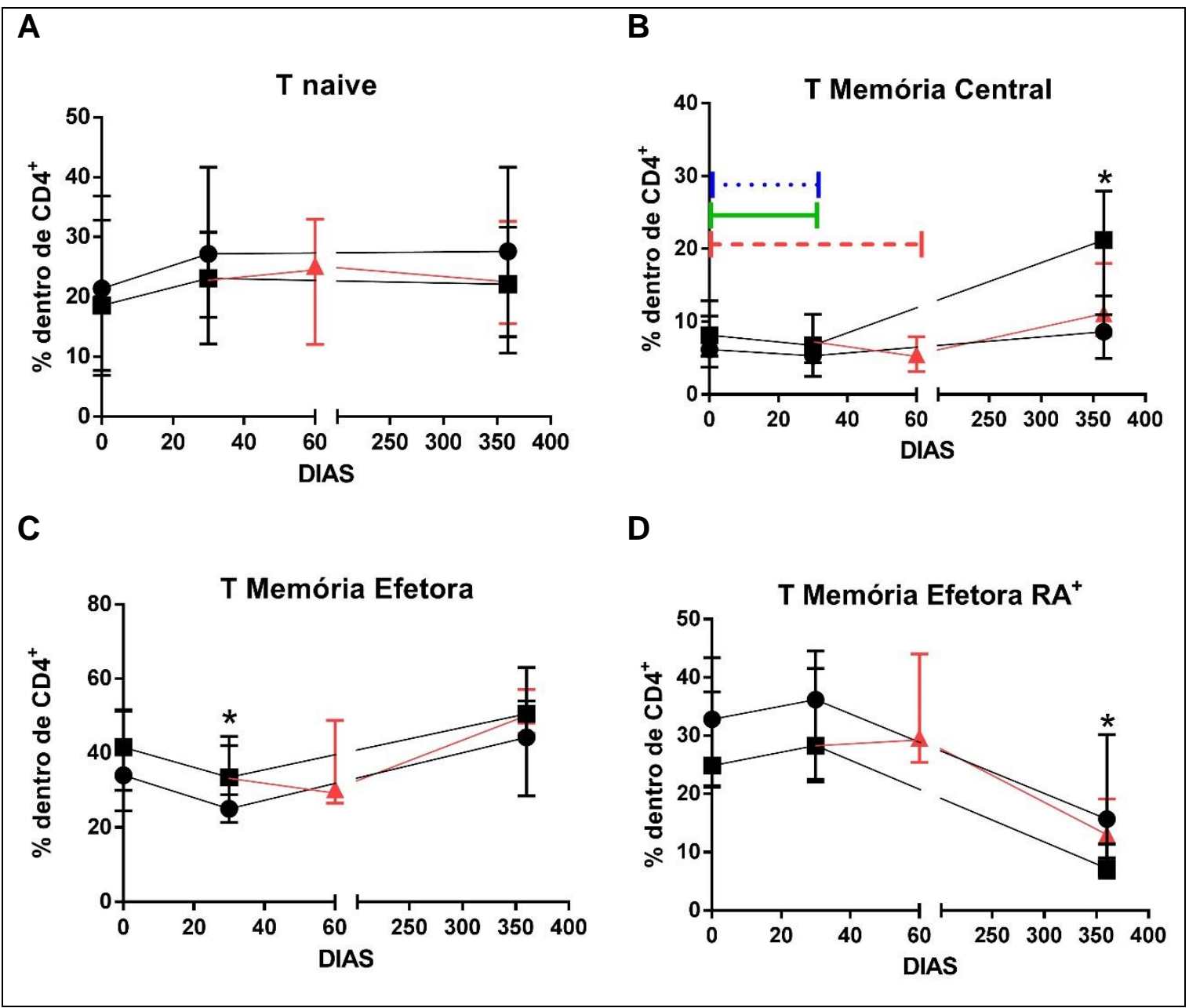

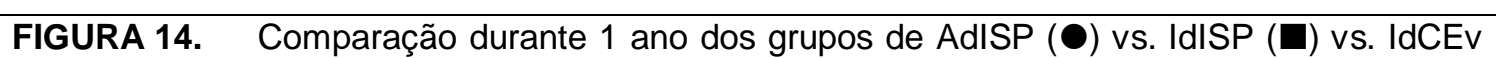
(A) quanto ao percentual de linfócitos $T$ naive $(A)$, Tmemória central $(B)$, T memória efetora (C) e $\mathrm{T}$ memoria efetora $\mathrm{RA}^{+}$(D). AdISP - adultos jovens transplantados renais com imunossupressão padrão, IdISP - idosos transplantados renais com imnunossupressão padrão, IdCEv - idosos transplantados renais convertidos para everolimo.

* Diferenças estatísticas $(p<0,05)$ na comparação de AdISP vs. IdISP.

A linha pontilhada azul se refere a diferença no grupo de AdISP em diferentes tempos. A linha continua verde se refere a diferenças no grupo IdISP em diferentes tempos. A linha interrompida vermelha se refere a diferenças no grupo IdCEv em diferentes tempos.

\subsubsection{Linfócitos $T$ reguladores}

Os números absolutos dos linfócitos TREG do fenótipo CD127-FoxP3+ não diferiram entre os grupos em nenhum dos pontos avaliados (tabela 7, figura 15A). Nas avaliações intra-grupo ao longo do tempo, os IdISP apresentaram redução transitória nos números de linfócitos TREG CD127-FoxP3 ${ }^{+}$com 30 dias do transplante (tabela 7, figura 15A). Para o fenótipo de linfócitos TREG CD127-FoxP3+CD39+ também não houve diferença nos números absolutos entre os grupos ao longo dos temos 
analisados (tabela 8, figura 15B). Entretanto, os IdISP apresentaram redução transitória nos números de linfócitos TREG CD127-FoxP3+CD39+ com 30 dias, diferença que se manteve na análise de 60 dias dos IdCEv, ocorrendo recuperação dos valores basais em ambos grupos de idosos com 1 ano (tabela 7, figura 15B). Os números de linfócitos TREG CD127-FoxP3+CD39+ dos AdISP apresentou redução com 30 dias e se mantinha reduzida em comparação ao basal com 1 ano do transplante (tabela 7, figura 15B).

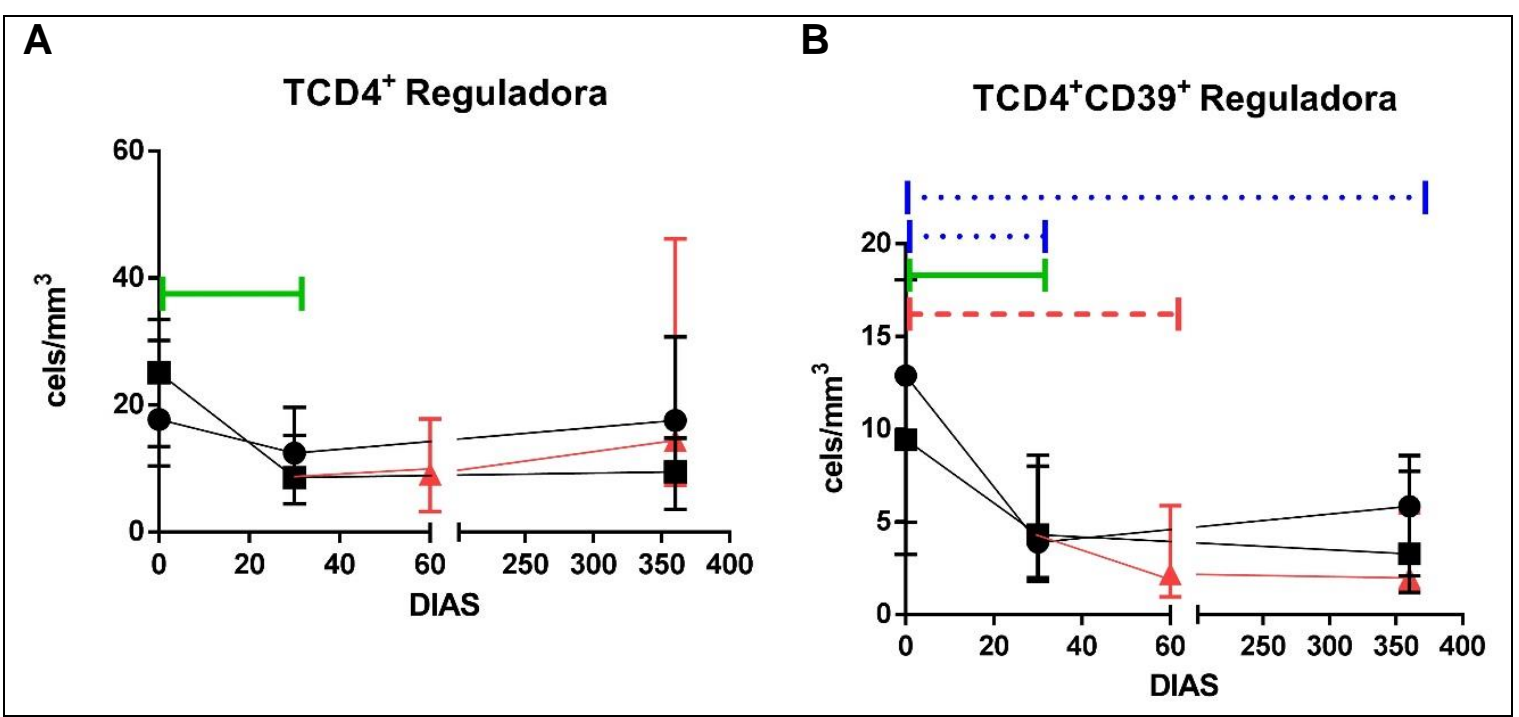

FIGURA 15. Comparação durante 1 ano dos grupos de AdISP (O) vs. IdISP ( $\mathbf{\square})$ vs. IdCEv (A) quanto ao número de linfócitos T reguladores $(A)$ e T reguladores CD39+ $(B)$. AdISP - adultos jovens transplantados renais com imunossupressão padrão, IdISP - idosos transplantados renais com imnunossupressão padrão, IdCEv - idosos transplantados renais convertidos para everolimo.

* Diferenças estatísticas $(p<0,05)$ na comparação de AdISP vs. IdISP.

As linhas pontilhadas azuis se referem a diferenças no grupo de AdISP em diferentes tempos. As linhas continuas verdes se referem a diferenças no grupo IdISP em diferentes tempos. A linha interrompida vermelha se refere a diferenças no grupo IdCEv em diferentes tempos.

Os pacientes IdISP, quando comparados aos AdISP, apresentaram maiores percentuais de linfócitos TREG em ambos os fenótipos analisados, CD127-FoxP3+ e $\mathrm{TCD}^{+}{ }^{+} \mathrm{CD} 39^{+}$na situação basal e com 30 dias do transplante (tabela 8, figura 16A e 16B). Com um ano do transplante, IdISP e AdISP não apresentavam diferenças nos 
percentuais de linfócitos TREGs (tabela 8, figura 16A e 16B). Tanto nos IdISP quanto nos AdISP foi observada redução nos percentuais de ambos fenótipos de linfócitos TREG com 30 dias de transplante (tabela 8, figura 16A e16B). Os IdCEv mantinham reduzidos os percentuais com 60 dias para o fenótipo $\mathrm{TCD}^{+}{ }^{+} \mathrm{CD} 39^{+}$(tabela 8 , figura 16B). O maior achado deste estudo foi a mantida redução dos percentuais dos linfócitos TREGs do fenótipo TCD4+CD39+ na avaliação de um ano dos pacientes AdISP, enquanto nos pacientes idosos em ambos os grupos, IdISP e IdCEv, os percentuais de linfócitos TREGs não diferiam dos valores basais (tabela 8, figura 16B).

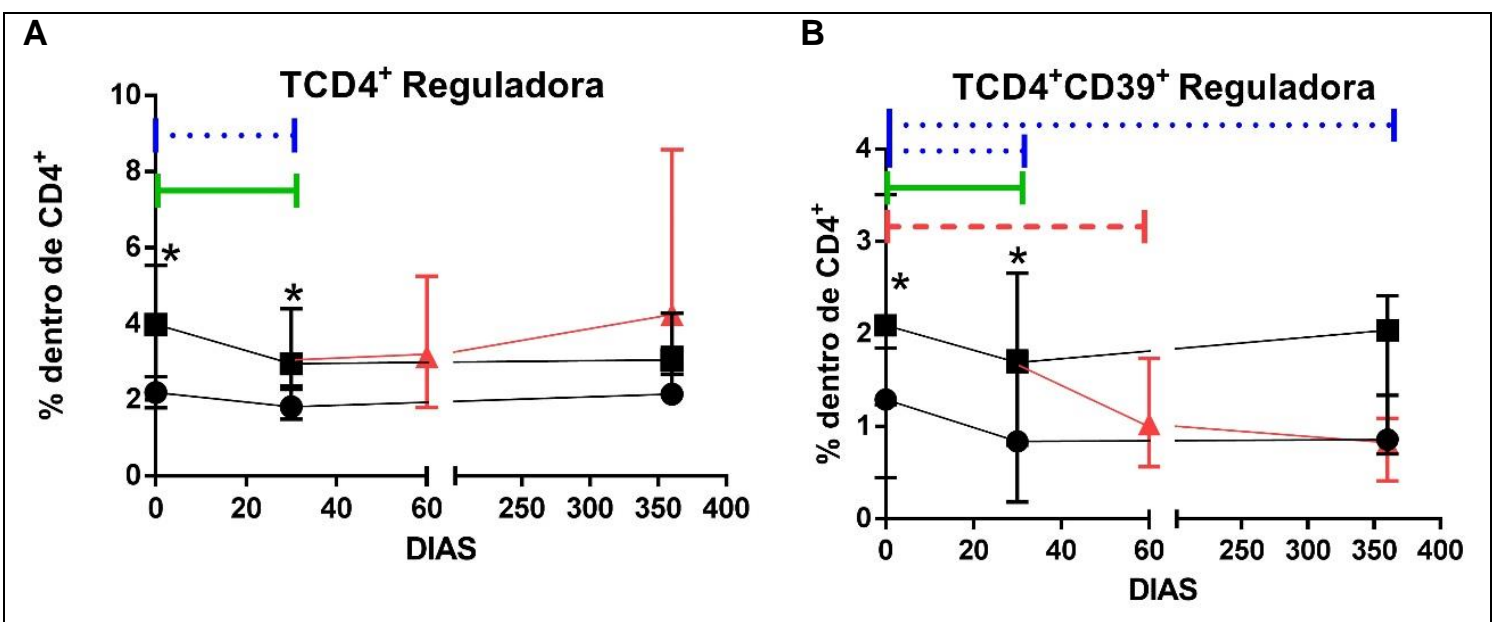

FIGURA 16. Comparação durante 1 ano dos grupos de AdISP $(\bullet)$ vs. IdISP $(\mathbf{\square})$ vs. IdCEv $(\Delta)$ quanto ao percentual de linfócitos T reguladores $(A)$ e T reguladores CD39+ $(B)$. AdISP adultos jovens transplantados renais com imunossupressão padrão, IdISP - idosos transplantados renais com imnunossupressão padrão, IdCEv - idosos transplantados renais convertidos para everolimo.

* Diferenças estatísticas $(p<0,05)$ na comparação de AdISP vs. IdISP.

As linhas pontilhadas azuis se referem às diferenças no grupo de AdISP em diferentes tempos. As linhas continuas verdes se referem às diferenças no grupo IdISP em diferentes tempos. A linha interrompida vermelha se refere às diferenças no grupo IdCEv em diferentes tempos. 


\subsubsection{Subpopulações de linfócitos $B$}

Dentre as subpopulações de linfócitos $B$, as alterações em números absolutos foram mais proeminentes nos linfócitos B naive e B memória (tabela 7, figura 17A e 17B). AdISP apresentavam maiores números de linfócitos $B$ naive antes do transplante e com 30 dias de transplante (tabela 7, figura 17A), comparado a IdISP. Os AdISP apresentaram uma elevação dos números de linfócitos B naive com 30 dias [165 (106-225) vs. 276 (143-430), $p=0,0013]$ com retorno aos valores basais com 1 ano (tabela 7, figura 17A). Ao final de 1 ano de transplante, não haviam diferenças nos números de linfócitos B naive entre os 3 grupos avaliados (tabela 7, figura 17A). AdISP, comparativamente aos IdISP, apresentaram maiores números absolutos de linfócitos B memória antes do transplante e com 30 dias do transplante, entretanto, com 1 ano, os AdISP mantinham maiores números de linfócitos B memória comparados aos IdISP, mas semelhantes aos IdCEv (tabela 7, figura 17B). Tanto AdISP [44 (23-52) vs. 97 (38-123), p=0,0003] como IdISP [21 (10-30) vs. 26 (17-46), $p=0,0129]$ apresentaram elevação transitória dos números de linfócitos $B$ memória com 30 dias de transplante (tabela 7, figura 17B). Em todos os tempos avaliados, os números de linfócios BREG não diferiam entre os grupos (tabela 7, figura 17C). Apenas no grupo IdCEv houve uma redução transitória do número de linfócitos BREG com 60 dias [7 (3-24) vs. 4 (1-9), $p=0,0024]$ (tabela 7, figura 17C). 


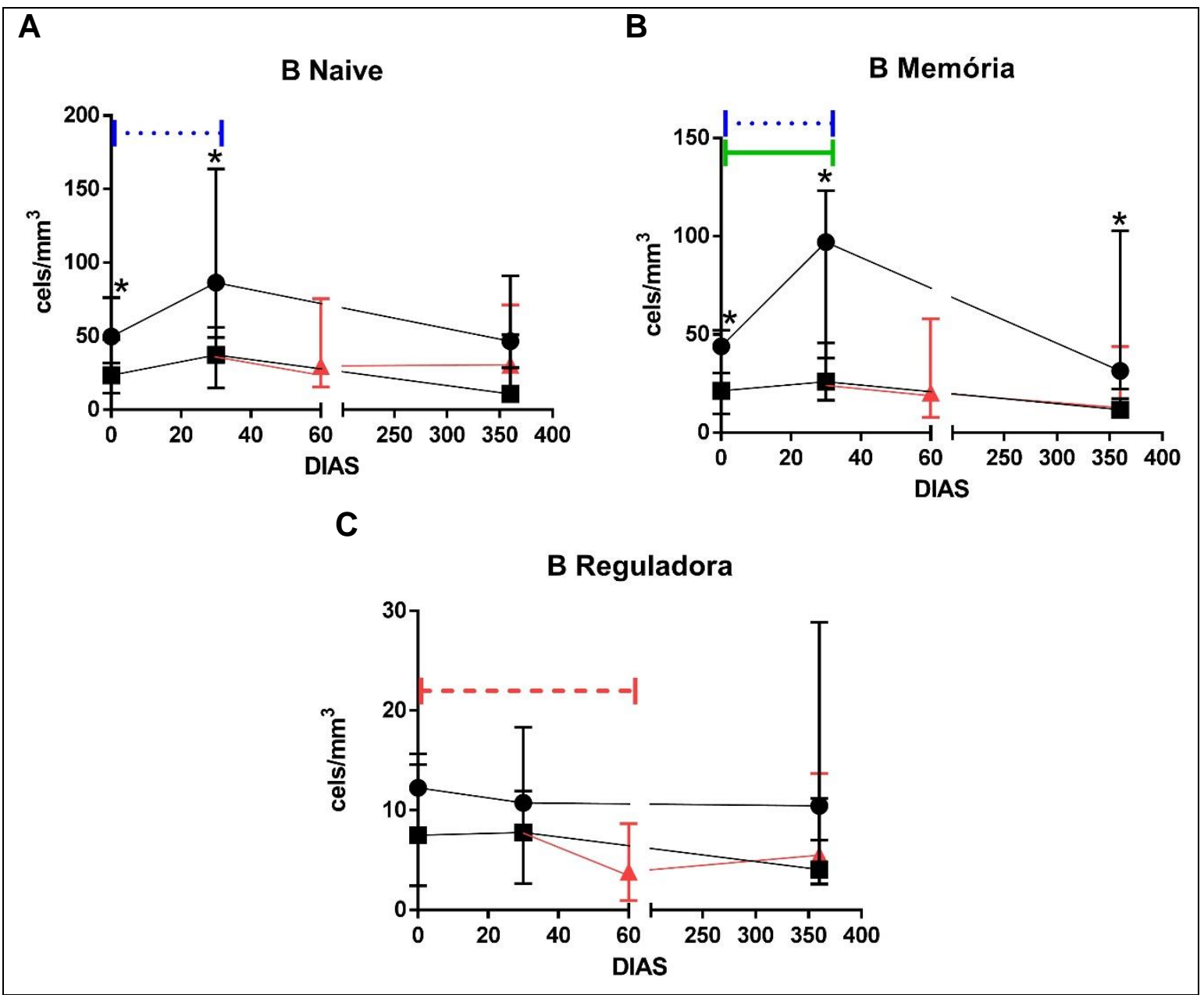

FIGURA 17. Comparação durante 1 ano dos grupos de AdISP $(\bullet)$ vs. IdISP $(\mathbf{\square})$ vs. IdCEv ( $\mathbf{A})$ quanto ao número de linfócitos $B$ naive $(A), B$ memória $(B)$ e $B$ reguladores (C). AdISP - adultos jovens transplantados renais com imunossupressão padrão, IdISP - idosos transplantados renais com imnunossupressão padrão, IdCEv - idosos transplantados renais convertidos para everolimo. * Diferenças estatísticas $(p<0,05)$ na comparação de AdISP vs. IdISP.

As linhas pontilhadas azuis se referem às diferenças no grupo de AdISP em diferentes tempos. $A$ linha continua verde se refere às diferenças no grupo IdISP em diferentes tempos. A linha interrompida vermelha se refere às diferenças no grupo IdCEv em diferentes tempos.

Os percentuais de linfócitos B naive não apresentaram variação ao longo do tempo em nenhum dos grupos e também não houve diferenças entre os grupos em nenhum dos momentos analisados (tabela 8, figura 18A). Os percentuais de linfócitos B memória não apresentavam diferença entre os grupos em nenhum dos pontos analisados (tabela 8, figura 18B). Mas, tanto os AdISP como os IdISP apresentaram elevação transitória do percentual de linfócitos B memória com 30 dias de transplante (tabela 8, figura 18B). Ainda, no grupo IdCEv, o aumento do percentual de linfócitos $B$ 
memória se mantinha na avaliação com 60 dias de transplante (tabela 8, figura 18B). Tanto nos AdISP quanto nos IdISP foi observada redução no percentual de linfócitos BREG com 30 dias do transplante (tabela 8, figura 18C). Com 1 ano do transplante, os percentuais de linfócitos BREG apresentaram recuperação posterior nos idosos de ambos os grupos, mas se mantinham reduzidos comparados a situação basal nos AdISP (tabela 8, figura 18C). Ainda, no grupo IdCEv foi observada uma nova redução nos percentuais de linfócitos BREG com 60 dias, com diferenças dos valores neste período comparativamente a situação basal e a 30 dias de transplante (tabela 8, figura 18C). Os percentuais de linfócitos BREG não diferiam entre AdISP e IdISP antes do transplante, nem com 1 ano de transplante, seja comparado a IdISP ou a IdCEv (tabela 8, figura 18C). Entretanto, com 30 dias do transplante, IdISP apresentavam maiores percentuais de linfócitos BREG comparado aos AdISP no memo momento (tabela 8, figura 18C). 


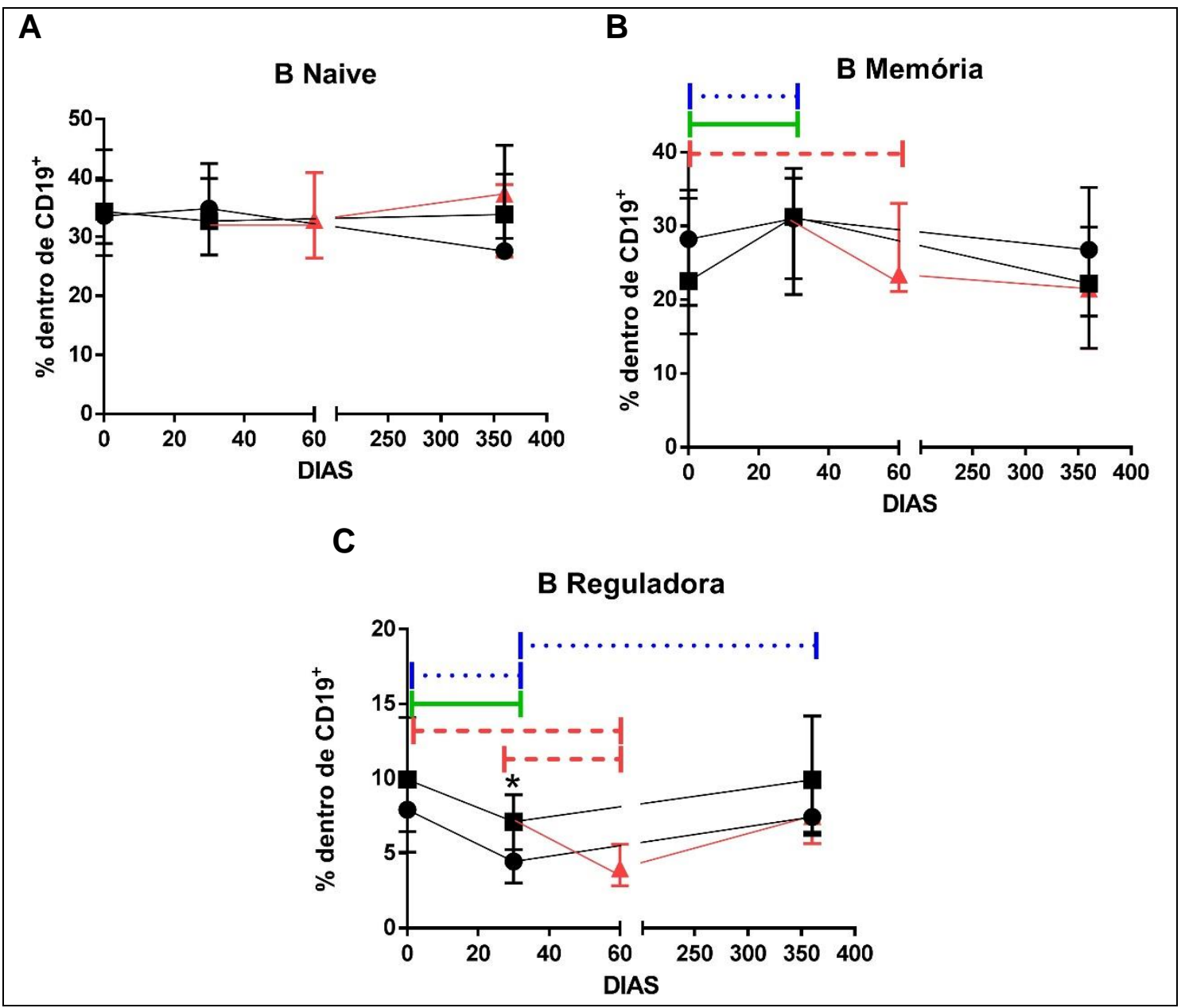

FIGURA 18. Comparação durante 1 ano dos grupos de AdISP $(\bullet)$ vs. IdISP $(\mathbf{\square})$ vs. IdCEv (A) quanto ao percentual de linfócitos $B$ naive (A), B memória (B) e B reguladores (C). AdISP - adultos jovens transplantados renais com imunossupressão padrão, IdISP - idosos transplantados renais com imnunossupressão padrão, IdCEv - idosos transplantados renais convertidos para everolimo.

* Diferenças estatísticas $(p<0,05)$ na comparação de AdISP vs. IdISP.

As linhas pontilhadas azuis se referem às diferenças no grupo de AdISP em diferentes tempos. As linhas continuas verdes se referem às diferenças no grupo IdISP em diferentes tempos. As linhas interrompidas vermelhas se referem às diferenças no grupo IdCEv em diferentes tempos. 


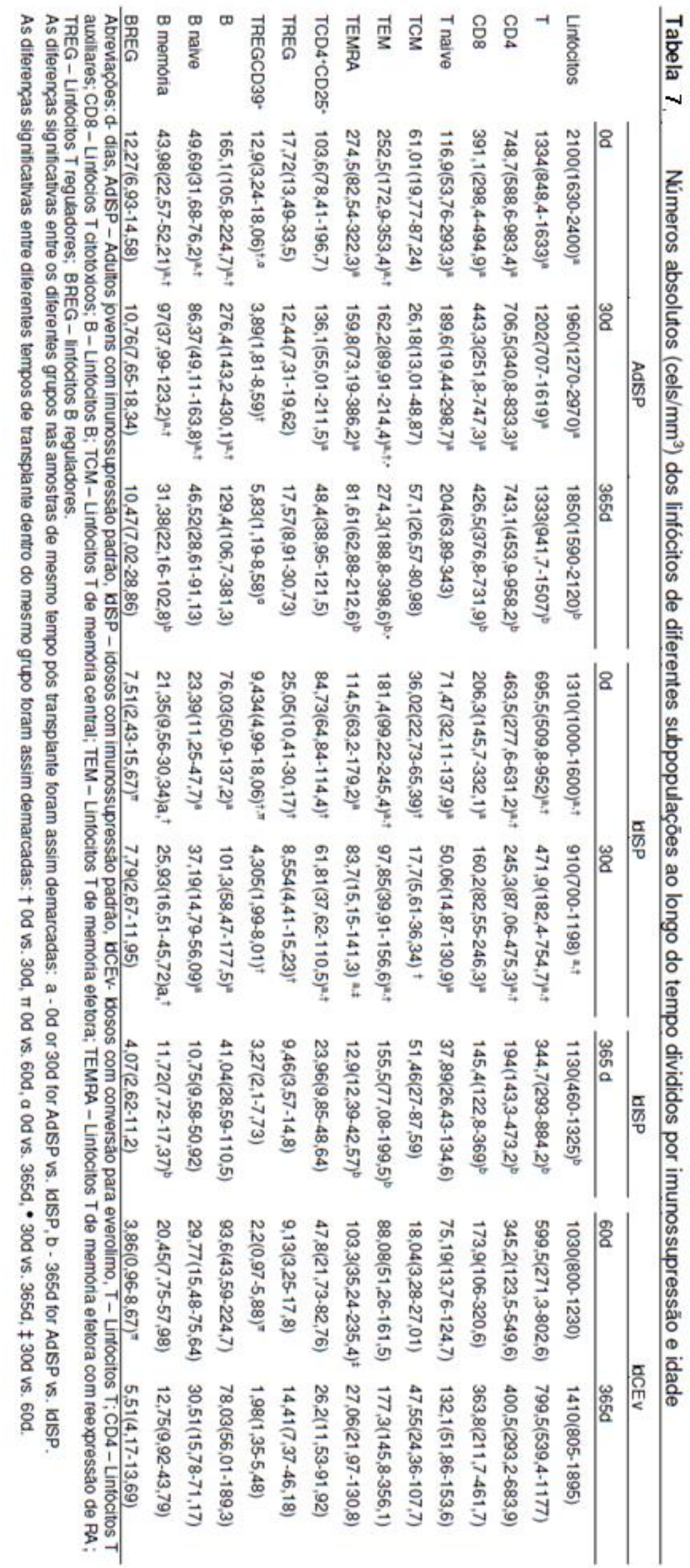




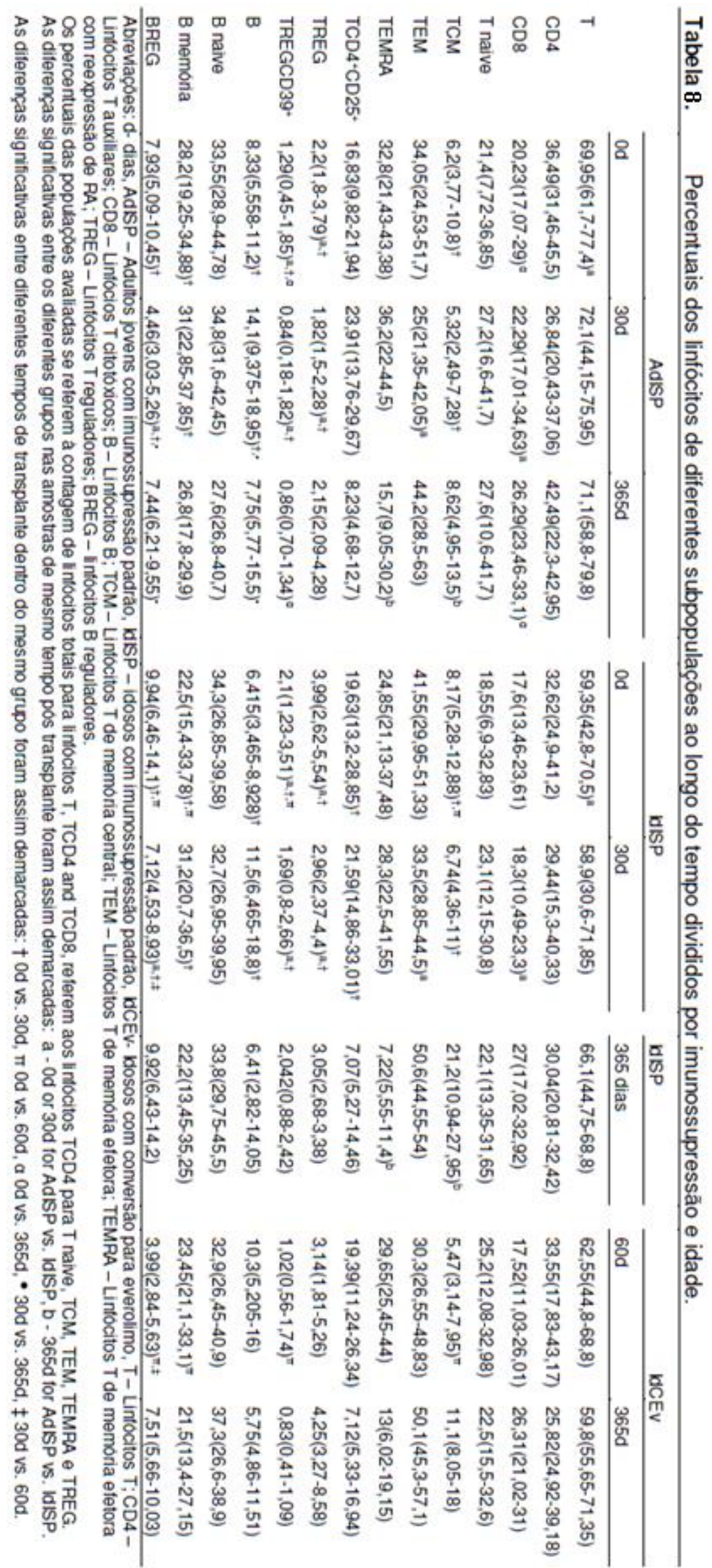




\section{Discussão}

\subsection{Efeitos de doença renal crônica e envelhecimento nas} populações linfocitárias

Neste estudo, analisamos subpopulações de linfócitos circulantes em idosos e adultos jovens com doença renal crônica na admissão para transplante renal e em grupo controle de voluntários sadios com objetivo de avaliar se doença renal crônica e envelhecimento alteram quantitativamente o perfil de diferenciação e maturação dos linfócitos $\mathrm{T}$ e $\mathrm{B}$ de sangue periférico. Envelhecimento modificou o perfil das subpopulações de linfócitos de indivíduos com doença renal crônica de maneira semelhante ao observado nos indivíduos sem doença renal crônica. Envelhecimento foi associado a redução global nos números absolutos de linfócitos totais, TCD4 e TCD8. As alterações observadas nas subpopulações linfocitárias foram mais evidentes nas subpopulações de linfócitos TCD4, com menores números absolutos de linfócitos $T$ naive e TEMRA e maiores percentuais de linfócitos TCM. Envelhecimento se associou, ainda, a maiores percentuais de linfócitos TREGs sem mudanças em seus números absolutos. Nas subpopulações de linfócitos $B$, o envelhecimento resultou em menores números absolutos de linfócitos BM com percentuais sem alterações.

Os achados deste estudo nas subpopulações T estão em acordo com a literatura que descreve idosos com menores populações T naive (GREGG; et al., 2005; KOCH; et al., 2008; LEFEBVRE; et al., 2012; SAULE; et al., 2006), maiores populações TCM (KOCH; et al., 2008) e maiores percentuais de linfócitos TREG (FARIA; et al., 2008; GREGG; et al., 2005; LEFEBVRE; et al., 2012). Não foram observadas diferenças nos números e percentual de linfócitos TEM, nem nos números 
absolutos de TREG, enquanto outros autores relatam maiores números absolutos e percentuais de linfócitos TEM (SAULE; et al., 2006), e maiores números absolutos de linfócitos TREG (GREGG; et al., 2005b). Apesar de algumas diferenças nas mudanças do perfil de linfócitos encontradas neste estudo não reproduzirem a literatura, estes resultados ainda amparam que, mesmo entre os indivíduos idosos com doença renal crônica, ocorre uma mudança nas subpopulações de linfócitos T para perfil memória em conjunto com aumento nas populações de perfil regulador.

A literatura relata que envelhecimento se associa a menores números absolutos e percentuais de linfócitos B (CARAUX; et al., 2010; CHONG; et al., 2005; FARIA; et al., 2008; MORBACH; EICHHORN; et al., 2010; VENERI; et al., 2007), com maiores percentuais de linfócitos BM (BULATI; et al., 2011; CHONG; et al., 2005; COLONNA-ROMANO; et al., 2006; MORBACH; et al., 2010). A literatura é divergente nas alterações do envelhecimento nas populações de linfócitos B naive e BREG, podendo seus percentuais estarem inalterados (CARAUX; et al., 2010) ou diminuídos (MORBACH; et al., 2010). Os achados nas subpopulações de linfócitos B deste trabalho não permitem conclusões dos efeitos do envelhecimento nesta subpopulação. As alterações observadas nas subpopulações de linfócitos B foram pequenas, sendo possivelmente um indicativo da necessidade de maior amostra para detectar diferenças entre os grupos e, assim, esclarecer se envelhecimento tem impactos nas subpopulações de linfócitos B.

Os achados deste estudo e de outros autores colaboram para a seguinte hipótese: a atrofia tímica nos idosos ocasiona redução no aporte tímico de linfócitos emigrantes tímicos, responsáveis pelo reestabelecimento do repertório de linfócitos T naive periféricos (BERZINS; et al., 2002; GREGG; et al., 2005; LYNCH; et al., 2009) e, consequente, ocorre a proliferação de linfócitos $\mathrm{T}$ periféricos mantendo 
parcialmente as contagens linfocitárias (BERZINS; et al., 2002; GREGG; et al., 2005; MORO-GARCÍA; et al., 2013; NAYLOR; et al., 2005). O resultado final é um aumento nos linfócitos T com perfil memória. Este fenômeno é, ainda, relevante no envelhecimento mesmo se houver doença renal crônica superposta.

Neste estudo, doença renal crônica se associou com redução global nos números absolutos de linfócitos totais, TCD4 e TCD8. Nas subpopulações de linfócitos TCD4 foi observada menor contagem absoluta de linfócitos T naive, TCM e TEMRA, com maiores percentuais de linfócitos TEM. Os menores percentuais de linfócitos TREG em doença renal crônica foram destoantes dos achados relacionados ao envelhecimento. Nos indivíduos com doença renal crônica, os linfócitos B apresentaram menores números absolutos em seus números totais e em todas subpopulações avaliadas.

Os efeitos da doença renal crônica descritos neste estudo estão em acordo com outros autores que também descrevem menores números absolutos de linfócitos totais (CHUNG; et al., 2012; FERNÁNDEZ-FRESNEDO; et al., 2000; KIM; et al., 2012; LISOWSKA; et al., 2014; LITJENS; et al., 2006; YOON; et al., 2006), linfócitos T (FERNÁNDEZ-FRESNEDO; et al., 2000; HENDRIKX; et al., 2009; LITJENS; et al., 2006) e linfócitos TCD4 (FERNÁNDEZ-FRESNEDO; et al., 2000; HENDRIKX; et al., 2009; LISOWSKA; et al., 2014; LITJENS; et al., 2006; YOON; et al., 2006), sem alterações nos percentuais de linfócitos T (FERNÁNDEZ-FRESNEDO; et al., 2000; LITJENS; et al., 2006), TCD4 (FERNÁNDEZ-FRESNEDO; et al., 2000; LISOWSKA; et al., 2014) e TCD8 (FERNÁNDEZ-FRESNEDO; et al., 2000; LITJENS; et al., 2006; YOON; et al., 2006), mas menores números absolutos de linfócitos T naive (LITJENS; et al., 2006; YOON; et al., 2006), menores números absolutos de linfócitos TCM (LITJENS; et al., 2006; YOON; et al., 2006) e maiores percentuais de linfócitos TEM 
(CHUNG; et al., 2012). No entanto, divergimos de outros autores que descrevem números absolutos mantidos de linfócitos TCD8 (FERNÁNDEZ-FRESNEDO; et al., 2000; LITJENS; et al. 2006; YOON; et al., 2006), menores percentuais de linfócitos T naive (CHUNG; et al., 2012; LISOWSKA; et al., 2014), e maiores percentuais de linfócitos TCM (CHUNG; et al., 2012). Neste estudo, encontramos menores percentuais de linfócitos TREG em pacientes com doença renal crônica, achado em acordo com estado mais pró-inflamatório desta condição. No entanto, este achado é divergente do de outros autores que descrevem números absolutos de linfócitos TREG sem mudanças (LISOWSKA; et al., 2014) ou menores (HENDRIKX; et al., 2009) e sem alterações nos percentuais de linfócitos TREG (AFZALI; et al., 2013; HENDRIKX; et al., 2009; KIM; et al., 2012; LIN; et al., 2012; LISOWSKA; et al., 2014). Vale relembrar que nos últimos anos houve importante mudança na caracterização fenotípica dos linfócitos T reguladores, com a descrição da proteína FoxP3 (HORI; et al., 2003), descrição da baixa expressão ou ausência de expressão de CD127 (LIU; et al., 2006), além da descrição de novos marcadores, como CD39 para população TREG de maior atividade (DWYER; et al., 2010). Os vários estudos são heterogêneos em suas definições, dificultando comparações acuradas.

Os achados deste estudo em linfócitos B na doença renal crônica convergem com a literatura descrevendo menores números absolutos de linfócitos B totais (FERNÁNDEZ-FRESNEDO; et al., 2000; HENDRIKX; et al., 2009; LITJENS; et al., 2006) e menores percentuais (FERNÁNDEZ-FRESNEDO; et al., 2000) com percentuais de linfócitos B naive e BREG mantidos (KIM; et al., 2012). Enquanto neste estudo não foram observadas mudanças nos percentuais de linfócitos BM, outros autores descrevem menores percentuais desta subpopulação (KIM; et al., 2012). 
As divergências de alguns resultados neste estudo podem estar relacionadas às diferenças no perfil de indíviduos com doença renal crônica incluídos nas diferentes referências. A diferença da média de idade entre os adultos jovens e idosos com doença renal crônica foi de 30 anos (35 vs. 65 anos) enquanto nos outros estudos os indivíduos com doença renal crônica encontravam-se todos entre a quarta e quinta década de vida (CHUNG; et al., 2012; FERNÁNDEZ-FRESNEDO; et al., 2000; KIM; et al., 2012; LIN; et al., 2012; LITJENS; et al., 2006; YOON; et al., 2006). Além disto, em vários estudos foram incluídos indivíduos com doença renal ainda sem terapia renal substitutiva (CHUNG; et al., 2012; FERNÁNDEZ-FRESNEDO; et al., 2000; KIM; et al., 2012; LISOWSKA; et al., 2014; LITJENS; et al., 2006) e vários destes pacientes não eram, necessariamente, elegíveis para transplante renal (CHUNG; et al., 2012; FERNÁNDEZ-FRESNEDO; et al., 2000; KIM; et al., 2012; LISOWSKA; et al., 2014; LITJENS; et al. 2006; YOON; et al. 2006). Ainda, indivíduos de outros estudos apresentavam tempo em terapia renal substitutiva com grande variabilidade (FERNÁNDEZ-FRESNEDO; et al., 2000; LISOWSKA; et al., 2014). Os pacientes deste estudo compunham grupamento de idosos e adultos jovens, todos em terapia renal substitutiva por período médio de 3 anos e elegíveis a transplante renal.

Os achados deste estudo corroboram para o conceito de senescência precoce no compartimento de linfócitos T com mudança favorecendo perfil memória nos pacientes com doença renal. Doença renal crônica ocasiona declínio precoce de função tímica (BETJES; et al., 2011), aumento de linfócitos T memória com diferenciação terminal (BETJES; et al., 2011; MEIJERS; et al., 2012) e maior ocorrência de apoptose dos linfócitos T naive (BETJES; et al., 2011). Essas mudanças no perfil de linfócitos semelhantes às do envelhecimento caracterizam senescência precoce do sistema imune (BETJES; et al., 2011; MEIJERS; et al., 2012) afetando o 
compartimento T. Nos indivíduos com doença renal crônica os linfócitos B apresentam redução nos números absolutos sem mudanças no seu perfil. Nos idosos com doença renal crônica, no entanto, o envelhecimento ainda tem importantes efeitos.

Apesar de descrevermos achados comuns aos de outros autores sobre efeitos de doença renal crônica e envelhecimento nas subpopulações linfocitárias, este estudo analisa simultaneamente ambos efeitos em número de fenótipos além do habitualmente descrito. A novidade desta análise é a avaliação da ocorrência concomitante dos dois eventos, demonstrando que esta combinação resulta em maior redução no número de todos linfócitos, mas sem efeito sinérgico destas variáveis, e ainda, com pouca mudança nos percentuais destas subpopulações, exceto por maior percentual de linfócitos BREG.

Como estas alterações nas subpopulações linfocitárias podem ser consideradas para a prática clínica do transplante renal de idosos com doença renal crônica?

Deve-se considerar que maiores números de linfócitos BREG e TREG se correlacionam com menores incidências de rejeição aguda (SAN SEGUNDO; et al., 2010; SHABIR; et al., 2015), tolerância operacional (SILVA; et al., 2012), e maiores taxas de filtração glomerular (SAN SEGUNDO; et al., 2010). As subpopulações BREG tembém tem efeito protetor ao enxerto renal (CHERUKURI; et al., 2014). Estes achados têm implicações na escolha da imunossupressão dos idosos receptores de transplante renal. Timoglobulina, in vivo, ocasiona redução nos números absolutos de linfócitos TREG (SEWGOBIND; et al., 2009) com elevação de seus percentuais (GURKAN; et al., 2010; LOPEZ; et al., 2006). Os inibidores da calcineurina impedem a indução de linfócitos TREG in vitro (BAAN; et al., 2005) de maneira dose dependente (MIROUX; et al., 2012), por outro lado, os inibidores da mTOR ocasionam geração de 
linfócitos TREG in vitro (CHEN; et al., 2010) e expansão de linfócitos TREG em estudos clínicos (MORELON; et al., 2010). Estudos e informações sobre o efeito das drogas imunossupressoras nas populações de linfócitos BREG ainda são limitados. Os inibidores da calcineurina (CHUNG; et al., 2014; LATORRE; et al., 2016) e da mTOR (LATORRE; et al., 2016) parecem resultar em redução das populações de linfócitos BREG, enquanto o belatacept parece favorecer a expansão das populações de linfócitos BREG (LEIBLER; et al., 2014).

Talvez os receptores idosos possam se beneficiar de menores doses e menores níveis séricos dos imuossupresores (DAVID-NETO; et al., 2016; DAVIDNETO; et al., 2017) com adequado controle de rejeição aguda e infecção. Uso de menor imunossupressão que poupe células com perfil regulador poderia ser estratégia que tire proveito do perfil linfocitário dos idosos sustentando incidência de rejeição aguda adequada e menor ocorrência de infecções. Esta estratégia é compatível com o uso de baixa dose de tacrolimo associado a inibidor da mTOR, estratégia proposta em análise clínica do presente estudo (DAVID-NETO E, 2016).

Apesar da amostra relativamente pequena, que pode ter influenciado a discriminação de diferenças estatísticas, o tamanho amostral é semelhante a de outros estudos com avaliação de subpopulações linfocitárias (BRAUDEAU; et al., 2007; GREGG; et al., 2005; KOCH; et al., 2008; LISOWSKA; et al., 2014; PAHL; et al., 2010; YOON; et al., 2006). Para considerarmos efeito atribuível a cada variável consideramos apenas significante as diferenças que ocorreram simultaneamente em ambos grupamentos de comparação de cada condição. Na análise dos agrupamentos com doença renal crônica (AdS vs. AdDRC e IdS vs. IdDRC) as diferenças nas idades dos grupos ocorreu de maneira oposta, no grupo de adultos, os sadios apresentavamse mais jovens e no de idosos, os sadios apresentavam-se mais velhos que suas 
contrapartes, assim, reforçando que as diferenças são atribuíveis à doença renal crônica. Nas analises agrupadas dos efeitos do envelhecimento (AdS vs. IdS e AdDRC vs. IdDRC) foram observadas as diferenças de idade de mesmo sentido, mas, mais estreita entre os indivíduos com doença renal crônica, assim diferenças encontradas simultaneamente nos controles saudáveis reforçam o efeito do envelhecimento nas análises de indivíduos com doença renal crônica. Ainda, as mesmas diferenças encontradas nas análises agrupadas estavam presentes na análise de variância. Conforme exposto, consideramos o tamanho amostral pequeno e número de controles não ideal, mas as conclusões se sustentam.

Concluindo, estes dados demonstram que envelhecimento e doença renal crônica resultam em menor número absoluto de linfócitos com polarização para perfil memória, divergindo quanto aos efeitos nas células TREGs. Os esquemas de imunossupressão em receptores idosos que preservem linfócitos TREGs e BREGs talvez possam melhorar resultados clínicos nesta população, mas um estudo clínico é necessário para avaliar esta possibilidade. 


\subsection{Efeito das medicações imunossupressoras nas}

\section{subpopulações linfocitárias de idosos transplantados renais}

Como mencionado anteriormente, o efeito do envelhecimento nas populações linfocitárias é ainda relevante nos pacientes com doença renal crônica (FREITAS; et al., 2019), uma linfopenia relativa associada a maiores percentuais de células com perfil memória e células T reguladoras (FARIA; et al., 2008; GREGG; et al., 2005; LEFEBVRE; et al., 2012) era esperada (FREITAS; et al., 2019).

Neste estudo, observou-se uma redução do número absoluto de linfócitos nos idosos, mas não nos adultos jovens no pós-transplante recente. Esta observação sugere que indução com menor dose de ATG associada a imunossupressão padrão resulte em maiores efeitos nos idosos nos primeiros meses de transplante. O maior efeito nos idosos pode ser resultado de maior apoptose de linfócitos T nos idosos ou à menor capacidade de repopulação linfocitária nestes indivíduos. Não existem estudos sobre os diferentes efeitos da ATG ou da imunossupressão de manutenção nas subpopulações linfocitárias conforme idade do receptor. Os dados atuais sugerem que os linfócitos oligoclonais senescentes são mais resistentes à apoptose (MOROGARCÍA; et al., 2012), apresentam menor capacidade proliferativa (MORO-GARCÍA; et al., 2012), e, ainda, que idosos tem menor produção de linfócitos tímicos (GREGG; et al., 2005; MORO-GARCÍA; et al., 2013; SIMONE; et al., 2008). Com estes achados de outros estudos, é mais provável que indução com ATG e imunossupressão padrão nos idosos requeira um maior período para reestabelecimento dos números de linfócitos pré-transplante. Com um ano de imunossupressão padrão, tanto nos idosos quanto nos adultos jovens houve retorno dos números de linfócitos aos valores basais. O retorno dos números de linfócitos aos valores basais sugere que o fator de maior influência nos números absolutos esteja relacionado ao uso da ATG e não aos efeitos 
dos imunossupressores de manutenção. Há relatos de que a intensidade e duração da linfodepleção induzida pelo uso da ATG ocorre de maneira dose dependente (KHO; et al., 2012), reforçando a maior susceptibilidade dos idosos aos efeitos das mesmas doses da ATG comparativamente aos adultos jovens.

As variações intra-grupo nas subpopulações de linfócitos T CD4 indicam uma maior importância da imuossupressão nestes linfócitos, em acordo com o predomínio de anticorpos dirigidos à estas células nas formulações de ATG (POPOW; et al., 2013).

Não houve mudanças nos percentuais de linfócitos T naive ao longo do tempo. O achado descrito foi inesperado, considerando que um efeito nesta subpopulação é frequentemente descrito (BOUVY; et al., 2013; GURKAN; et al., 2010; SEWGOBIND; et al., 2009; TANG; et al., 2012). Entretanto, é importante dastacar que os achados da literatura consideram doses habituais de ATG $(6 \mathrm{mg} / \mathrm{Kg}$ ) (GURKAN; et al., 2010; SEWGOBIND; et al., 2009; TANG; et al., 2012) ou análises in vitro (LOPEZ; et al., 2006). Indução com baixa dose de ATG com qualquer esquema de manutenção parece não alterar os percentuais de linfócitos $T$ naive nos momentos precoces ou tardios do transplante. Não há estudos da imunossupressão padrão na subpopulação de linfócitos $T$ naive ao longo do tempo, nem do impacto da ATG ou da imunossupressão de manutenção nos linfócitos T naive nos diferentes grupos etários.

Não eram esperados efeitos nos percentuais de linfócitos TEM e TEMRA considerando que os linfócitos memória são mais resistentes a indução com ATG in vivo (TANG; et al., 2012). No entanto, com 30 dias, o percentual dos linfócitos TEM nos idosos, não se elevou, mas se tornou maior que nos adultos jovens. Esta alteração foi atribuída a maior resistência dos linfócitos T memória à ATG em imunossupressão 
baseada em inibidores de calcineurina (TANG; et al., 2012), além da maior resistência à apoptose dos linfócitos de idosos (MORO-GARCÍA; et al., 2012).

As alterações nos percentuais de linfócitos TCM ocorreram de maneira inesperada no pós-transplante recente, com queda dos percentuais em idosos e adultos jovens. A resistência relativa dos linfócitos memória aos imunossupressores (BOUVY; et al., 2013; GURKAN; et al., 2010; SEWGOBIND; et al., 2009) não foi observada com 30 e 60 dias do transplante. Mas, os percentuais de linfócitos TCM se tornaram aumentados nos idosos em imunossupressão padrão com 1 ano, sem a manutenção dos maiores percentuais de linfócitos TEM, podendo, este efeito, decorrer de uma resposta imune mais acentuada dependente de linfócitos memória dos idosos após o transplante, primeiramente na subpopulação de TEM e depois na subpopulação de TCM.

Curiosamente, com 30 dias, os idosos apresentaram redução nos números absolutos de linfócitos $\mathrm{TCD} 4{ }^{+} \mathrm{CD} 25^{+}$com aumento nos seus percentuais. Esse padrão de alteração não foi observado nos adultos jovens. Com 1 ano, ambos grupos de idosos, apresentaram números absoludos e percentuais de linfócitos CD4+CD25+ semelhantes à condição basal. Esses achados sugerem que os linfócitos T ativados dos idosos se encontram em plena atividade com 30 dias do transplante. A expressão de CD25+ não é exclusiva dos linfócitos TREGs, ao contrário, os linfócitos T ativados apresentam grande expressão deste marcador (HOSONO; et al., 2003; POULTON; et al., 1988). Os achados descritos são condizentes com o esperado, demonstrando que a resposta imunológica é mais evidente no período do pós-transplante recente entre os idosos, mesmo que utilizada indução com ATG e imunossupressão padrão. Nos adultos jovens, a elevação transitória dos percentuais de linfócitos TCD4+CD25+ talvez tenham ocorrido em período mais precoce considerando o reestabelecimento 
linfocitário mais rápido neste grupo, justificando a não ocorrência desta alteração nas amostras avaliadas.

Protocolos de expansão de linfócitos TREG in vitro habitualmente se baseiam na exposição a inibidores da mTOR (BATTAGLIA; et al., 2012; SCOTTÀ; et al., 2013), assim como há estudos clínicos associando uso de inibidores da mTOR com aumento das populações de linfócitos TREG (BANSAL; et al., 2013; MORELON; et al., 2010). No entanto, os dados clínicos do uso de inibidores da mTOR geralmente avaliam protocolos de conversão e comparam imunossupressão baseada no uso de inibidores da calcineurina com imunossupressão baseada em inibidores da mTOR (BANSAL; et al., 2013). Há, ainda, um estudo de conversão para monoterapia com inibidor da mTOR com estes achados (HENDRIKX; et al., 2009). Não temos notícias de estudos avaliando, especificamente, os efeitos dos inibidosres da mTOR em idosos, nem dos efeitos da imunossupressão de manutenção com uso da combinação de inibidores da mTOR e inibidores da calcineurina. Baseado nos estudos atuais, não é possível predizer os efeitos do uso da combinação everolimo e tacrolimo nas populações linfocitárias dos idosos, mas, a expectativa é de favorecimento da população de linfócitos TREG.

Terapia linfodepletora com ATG se associa ao favorecimento da população TREG in vitro (LOPEZ; et al., 2006) e in vivo associada ao uso de terapia de imunossupressão padrão com inibidor da calcineurina (GURKAN; et al., 2010; KRYSTUFKOVA; et al., 2012; SEWGOBIND; et al., 2009; TANG; et al., 2012). Indução com ATG em diferentes idades ou com uso da combinação de inibidores da mTOR e inibidores de calcineurina não foram relatados.

Neste estudo, idosos e adultos jovens apresentaram números absolutos de linfócitos TREG semelhantes antes do transplante, mas com maiores percentuais de 
linfócitos TREG no grupo de idosos, dado previamente publicado pelo nosso grupo, encontrando maior perfil regulador entre idosos, mesmo com doença renal crônica (FREITAS; et al., 2019). Os números absolutos dos linfócitos TREG para ambos fenótipos estudados apresentaram redução em 30 dias no grupo de idosos, associada a redução de seus percentuais para idosos e adultos jovens. Entre os idosos, houve persistência do decremento nos percentuais de linfócitos TREG do fenótipo TCD4 ${ }^{+} \mathrm{CD} 39^{+}$com 60 dias, mesmo quando da conversão para uso de inibidor de mTOR. Com um ano, os percentuais dos linfócitos TREG não apresentavam diferenças comparativamente à situação basal em ambos os grupos de idosos. Entre os adultos jovens houve decremento persistente nos percentuais de linfócitos TREG do fenótipo TCD4+CD39+ com um ano. Como não ocorreu a esperada expansão de linfócitos TREG nos períodos iniciais do transplante renal, acreditamos que seja resultado do uso concomitante do inibidor de calcineurina. A manutenção de percentuais de linfócitos TREGs com um ano entre ambos grupos de idosos sugere que este efeito seja atribuível à idade e não às medicações imunossupressoras empregadas

Os jovens transplantados apresentavam maiores números de linfócitos B, refletidos em maiores números de linfócitos $B$ naive e $B$ memória em situação basal e com 30 dias de transplante. Apresentavam, ainda, tanto jovens quanto idosos, elevação percentual transitória dos linfócitos B e B memória com 30 dias de transplante. O Aumento absoluto dos linfócitos B memória também resultou em aumento em seu percentual com 30 dias de transplante. Na população BREG observou-se redução transitória de percentuais nos adultos e idosos com 30 dias, além de maiores percentuaisde BREGs nos idosos com 30 dias. 
As alterações descritas no compartimento de linfócitos B ocorreram de maneira mais evidente no transplante precoce e parecem refletir uma resposta imunológica mais importante no compartimento de linfócitos B nestes momentos. A resposta inicial mais proeminente dos linfócitos B possivelmente atribui-se ao efeito predominante da ATG nas populações T. A ocorrência de maior população BREG nos idosos comparativamente aos jovens com 30 dias pode ser relacionada a um perfil mais regulador dos idosos em fases iniciais. A literatura é pouco acertiva sobre as variações das populações de linfócitos B após o transplante. Há relatos de redução do número de linfócitos B (KHO; et al., 2012) com uso de ATG em doses habituais e de redução tardia da população B memória (GURKAN; et al., 2010). Tanto inibidores da calcineurina (CHUNG; et al., 2014; LATORRE; et al., 2016) como inibidores da mTOR (LATORRE; et al., 2016) parecem também reduzir as populações BREG. Sobre variações de linfócitos $B$ após transplante em diferentes faixas etárias desconhecemos fontes.

Com os resultados deste estudo e poucas fontes da literatura não é possível conclusões assertivas sobre a cinética dos linfócitos B nos pacientes idosos após o transplante, tampouco é possível inferir sobre os efeitos dos diferentes imunossupressores.

O presente estudo tem um tamanho amostral pequeno que pode ter influenciado a discriminação das diferenças estatísticas. No entanto, considerando a análise sem precedente na literatura avaliando o efeito das drogas imunossupressoras nas subpopulações linfocitárias de diferentes grupos etários associada a resultados instigantes, considetramos trabalho digno de atenção

Este trabalho prospectivo sobre variações nas populações linfocitárias reforça que os efeitos habitualmente descritos para as drogas imunossupressoras in vitro e 
na conversão, in vivo, não são claramente observadas com uso de indução e imunossupressão tripla habituais.

Os resultados do uso de indução com baixa dose de ATG e conversão precoce para everolimo combinado a baixa dose de tacrolimo não resultou em expansão das populações de linfócitos TREG. Ainda assim, o envelhecimento favoreceu a manutenção das populações de linfócitos TREG no transplante tardio independentemente da imunossupressão de manutenção utilizada. O maior impacto da ATG nos números de linfócitos dos pacientes idosos e maior tempo para reestabelecimento destes linfócitos é uma novidade à literatura e suscita a consideração de que a dose de ATG nos idosos talvez deva ser reconsiderada, independentemente da imunossupressão de manutenção escolhida. 


\section{CONCLUSÕES}

Senescência e uremia resultam em menores contagens absolutas das várias subpopulações linfocitárias. Quanto às populações reguladoras, uremia e senescência apresentam efeitos divergentes, com a senescência mais favorável a um perfil regulador. Observamos, ainda, que não há interação entre as duas variáveis, mas um efeito aditivo da sua co-ocorrência.

O uso de indução com baixa dose de ATG e conversão precoce para everolimo combinado a baixa dose de tacrolimo não resultou em expansão das populações de linfócitos reguladores para linfócitos T ou B. Entretanto, o envelhecimento, por si, favoreceu a manutenção das populações de linfócitos TREG no transplante tardio, bem como populações BREG nos momentos iniciais do transplante.

ATG ocasionou mudanças mais drásticas nos números de linfocitos dos pacientes idosos, possivelmente por necessitarem de maior tempo para reestabelecimento das populações periféricas.

Os achados desta casuística e da literatura sugerem que a combinação de senescência e uremia em conjunto resulte em alterações imunológicas específicas nos idosos candidatos ao transplante renal. Ainda, os efeitos das medicações imunossupressoras avaliadas, ATG e EVL, são diferentes entre idosos e adultos. A preocupação com individualização da imunossupressão dos idosos é amplamente justificada por estes achados. Consideramos, ainda, que é necessária a melhor compreenção dos efeitos dos agentes imunosssuopressores no sistema imunologico dos idosos durante o seguimento do transplantado renal. 


\section{SUPLEMENTOS}

As múltiplas comparações realizadas não foram totalmente descritas no texto e as diferenças expostas nas tabelas 7 e 8 apenas se estatisticamente significantes. Os resultados pormenorizados as avaliações estatísticas estão disponíveis nas tabelas suplementares 1,2 e 3 expostas abaixo. 


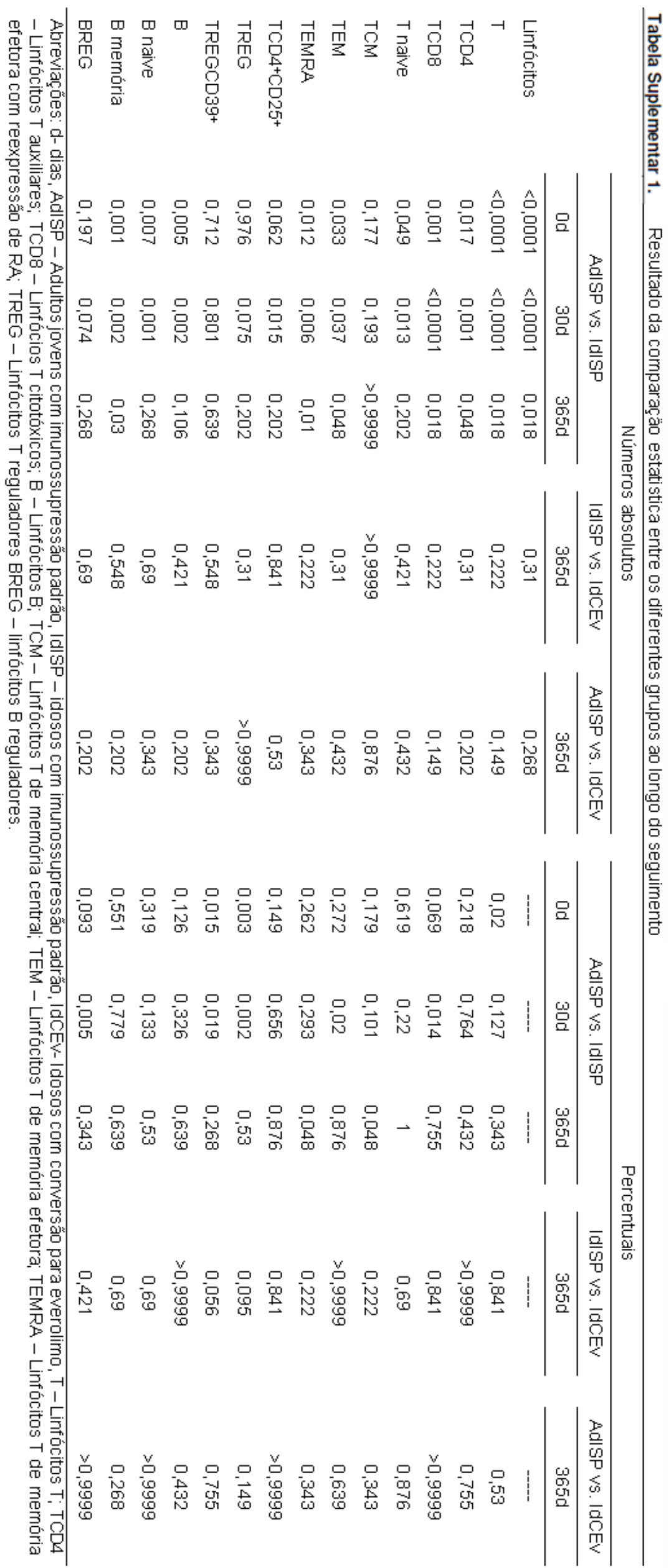




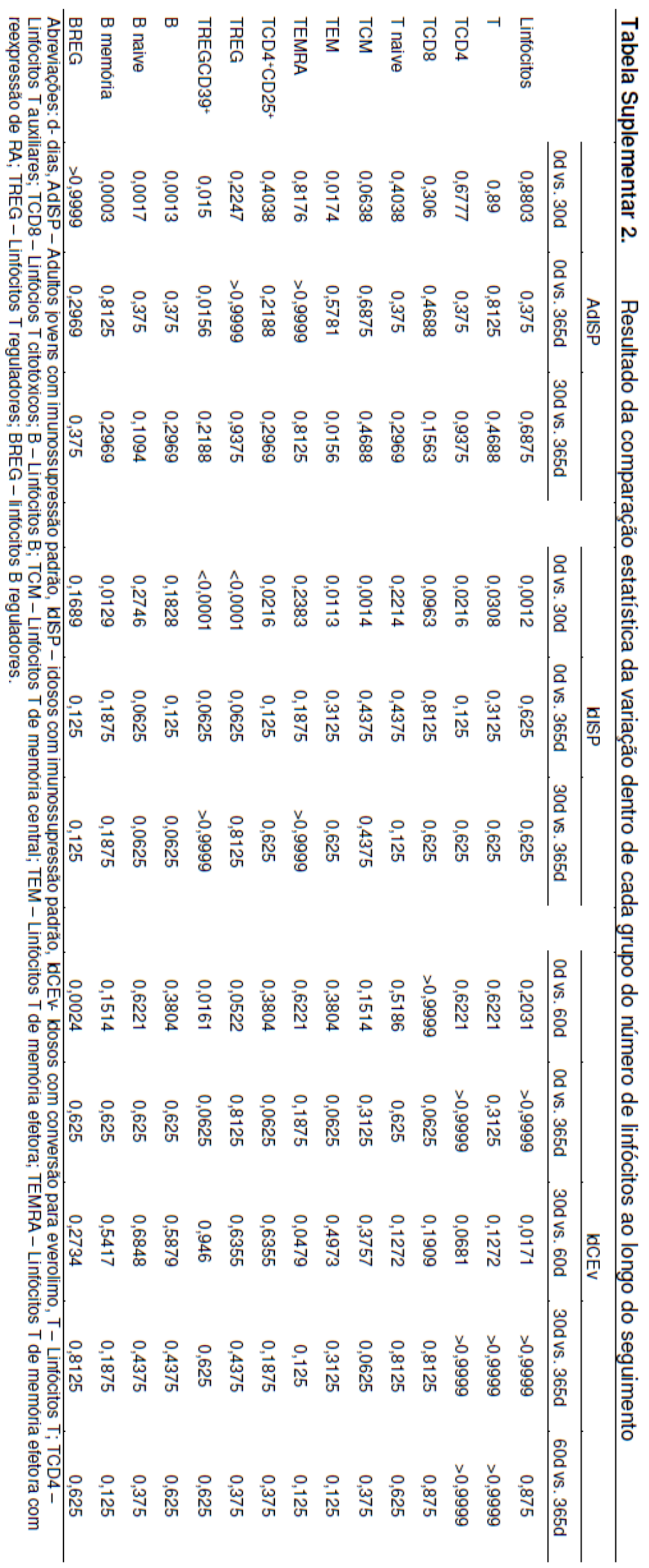




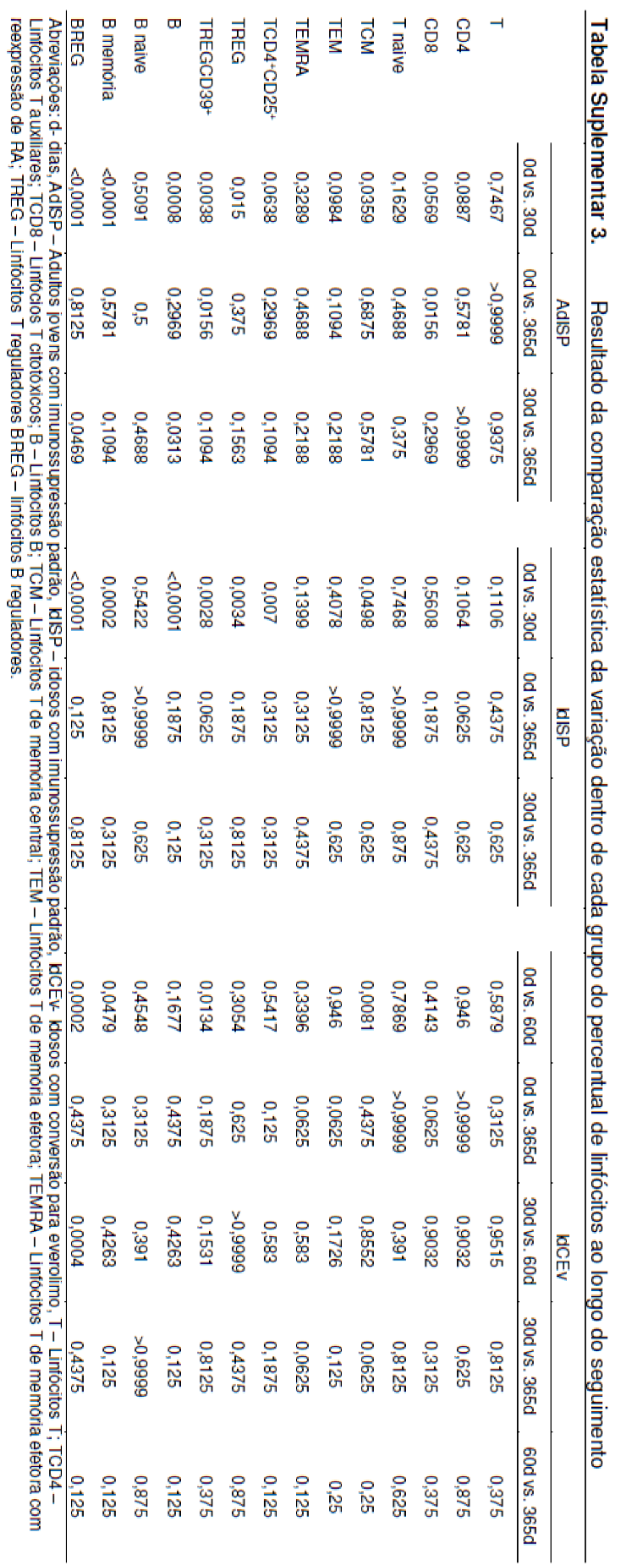




\section{REFERÊNCIAS}

ABE, M.; KAWAI, T.; FUTATSUYAMA, K.; TANABE, K. et al. Postoperative production of anti-donor antibody and chronic rejection in renal transplantation. Transplantation, 63, n. 11, p. 1616-1619, Jun 1997. ISSN 0041-1337. Disponível em: < http://www.ncbi.nlm.nih.gov/pubmed/9197356 >.

AFZALI, B.; EDOZIE, F. C.; FAZEKASOVA, H.; SCOTTÀ, C. et al. Comparison of regulatory T cells in hemodialysis patients and healthy controls: implications for cell therapy in transplantation. Clin J Am Soc Nephrol, 8, n. 8, p. 1396-1405, Aug 2013. ISSN 1555-905X. Disponível em: < https://www.ncbi.nlm.nih.gov/pubmed/23580782 >.

BAAN, C. C.; VAN DER MAST, B. J.; KLEPPER, M.; MOL, W. M. et al. Differential effect of calcineurin inhibitors, anti-CD25 antibodies and rapamycin on the induction of FOXP3 in human T cells. Transplantation, 80, n. 1, p. 110-117, Jul 2005. ISSN 0041-1337. Disponível em: < http://www.ncbi.nlm.nih.gov/pubmed/16003241 >.

BANSAL, D.; YADAV, A. K.; KUMAR, V.; MINZ, M. et al. Deferred pre-emptive switch from calcineurin inhibitor to sirolimus leads to improvement in GFR and expansion of T regulatory cell population: a randomized, controlled trial. PLoS One, 8, n. 10, p. e75591, 2013. ISSN 1932-6203. Disponível em: < http://www.ncbi.nlm.nih.gov/pubmed/24146762 >.

BATTAGLIA, M.; STABILINI, A.; TRESOLDI, E. Expanding human T regulatory cells with the mTORinhibitor rapamycin. Methods Mol Biol, 821, p. 279-293, 2012. ISSN 1940-6029. Disponível em: < https://www.ncbi.nlm.nih.gov/pubmed/22125072 >.

BENICHOU, G.; GONZALEZ, B.; MARINO, J.; AYASOUFI, K. et al. Role of Memory T Cells in Allograft Rejection and Tolerance. Front Immunol, 8, p. 170, 2017. Disponível em: < https://www.ncbi.nlm.nih.gov/pubmed/28293238 >.

BERZINS, S. P.; ULDRICH, A. P.; SUTHERLAND, J. S.; GILL, J. et al. Thymic regeneration: teaching an old immune system new tricks. Trends Mol Med, 8, n. 10, p. 469-476, 2002. Disponível em: < https://www.ncbi.nlm.nih.gov/pubmed/12383769 >.

BETJES, M. G.; LANGERAK, A. W.; VAN DER SPEK, A.; DE WIT, E. A. et al. Premature aging of circulating T cells in patients with end-stage renal disease. Kidney Int, 80, n. 2, p. 208-217, Jul 2011. ISSN 15231755. Disponível em:<https://www.ncbi.nlm.nih.gov/pubmed/21525849 >.

BLAIR, P. A.; NOREÑA, L. Y.; FLORES-BORJA, F.; RAWLINGS, D. J. et al. CD19(+)CD24(hi)CD38(hi) B cells exhibit regulatory capacity in healthy individuals but are functionally impaired in systemic Lupus Erythematosus patients. Immunity, 32, n. 1, p. 129-140, Jan 2010. ISSN 1097-4180. Disponível em: < http://www.ncbi.nlm.nih.gov/pubmed/20079667 >. 
BOHNHORST, J.; BJØRGAN, M. B.; THOEN, J. E.; NATVIG, J. B. et al. Bm1-Bm5 classification of peripheral blood $B$ cells reveals circulating germinal center founder cells in healthy individuals and disturbance in the B cell subpopulations in patients with primary Sjögren's syndrome. J Immunol, 167, n. 7, p. 36103618, Oct 2001. ISSN 0022-1767. Disponível em: < http://www.ncbi.nlm.nih.gov/pubmed/11564773 $>$.

BOUVY, A. P.; KHO, M. M.; KLEPPER, M.; LITJENS, N. H. et al. Kinetics of homeostatic proliferation and thymopoiesis after rATG induction therapy in kidney transplant patients. Transplantation, 96, n. 10, p. 904-913, Nov 2013. ISSN 1534-6080. Disponível em: < http://www.ncbi.nlm.nih.gov/pubmed/23985721 >.

BRAUDEAU, C.; RACAPE, M.; GIRAL, M.; LOUIS, S. et al. Variation in numbers of CD4+CD25highFOXP3+ T cells with normal immuno-regulatory properties in long-term graft outcome. Transpl Int, 20, n. 10, p. 845-855, Oct 2007. ISSN 0934-0874. Disponível em: < http://www.ncbi.nlm.nih.gov/pubmed/17854443 >.

BRISCOE, D. M.; SAYEGH, M. H. A rendezvous before rejection: where do T cells meet transplant antigens? Nat Med, 8, n. 3, p. 220-222, Mar 2002. ISSN 1078-8956. Disponível em: < http://www.ncbi.nlm.nih.gov/pubmed/11875489 >.

BULATI, M.; BUFFA, S.; CANDORE, G.; CARUSO, C. et al. B cells and immunosenescence: a focus on IgG+IgD-CD27- (DN) B cells in aged humans. Ageing Res Rev, 10, n. 2, p. 274-284, Apr 2011. ISSN 18729649. Disponível em: < http://www.ncbi.nlm.nih.gov/pubmed/21185406 >.

CARAUX, A.; KLEIN, B.; PAIVA, B.; BRET, C. et al. Circulating human B and plasma cells. Age-associated changes in counts and detailed characterization of circulating normal CD138- and CD138+ plasma cells. Haematologica, 95, n. 6, p. 1016-1020, Jun 2010. ISSN 1592-8721. Disponível em: < http://www.ncbi.nlm.nih.gov/pubmed/20081059 >.

CENSUS-BUREAU. International Data Base. 2016. Disponível em: https://www.census.gov/population/international/data/idb/informationGateway.php. Acesso em: 01/03/2017.

CHEN, J. F.; GAO, J.; ZHANG, D.; WANG, Z. H. et al. CD4+Foxp3+ regulatory T cells converted by rapamycin from peripheral $\mathrm{CD} 4+\mathrm{CD} 25(-)$ naive $\mathrm{T}$ cells display more potent regulatory ability in vitro. Chin Med J (Engl), 123, n. 7, p. 942-948, Apr 2010. ISSN 0366-6999. Disponível em: < http://www.ncbi.nlm.nih.gov/pubmed/20497692 >.

CHERUKURI, A.; ROTHSTEIN, D. M.; CLARK, B.; CARTER, C. R. et al. Immunologic human renal allograft injury associates with an altered IL-10/TNF- $\alpha$ expression ratio in regulatory B cells. J Am Soc Nephrol, 25, n. 7, p. 1575-1585, Jul 2014. ISSN 1533-3450. Disponível em: < http://www.ncbi.nlm.nih.gov/pubmed/24610932 >.

CHONG, Y.; IKEMATSU, H.; YAMAJI, K.; NISHIMURA, M. et al. CD27(+) (memory) B cell decrease and apoptosis-resistant CD27(-) (naive) B cell increase in aged humans: implications for age-related 
peripheral B cell developmental disturbances. Int Immunol, 17, n. 4, p. 383-390, Apr 2005. ISSN 09538178. Disponível em: < http://www.ncbi.nlm.nih.gov/pubmed/15724062 >.

CHUNG, B. H.; KIM, K. W.; KIM, B. M.; PIAO, S. G. et al. Dysregulation of Th17 cells during the early post-transplant period in patients under calcineurin inhibitor based immunosuppression. PLoS One, 7, n. 7, p. e42011, 2012. ISSN 1932-6203. Disponível em: < http://www.ncbi.nlm.nih.gov/pubmed/22848688 >.

CHUNG, B. H.; KIM, K. W.; SUN, I. O.; CHOI, S. R. et al. Increased interleukin-17 producing effector memory T cells in the end-stage renal disease patients. Immunol Lett, 141, n. 2, p. 181-189, Jan 2012. ISSN 1879-0542. Disponível em: < https://www.ncbi.nlm.nih.gov/pubmed/22004873 >.

CHUNG, B. H.; KIM, K. W.; YU, J. H.; KIM, B. M. et al. Decrease of immature B cell and interleukin-10 during early-post-transplant period in renal transplant recipients under tacrolimus based immunosuppression. Transpl Immunol, 30, n. 4, p. 159-167, May 2014. ISSN 1878-5492. Disponível em: $\langle$ http://www.ncbi.nlm.nih.gov/pubmed/24709525 $>$.

CLATWORTHY, M. R. Targeting B cells and antibody in transplantation. Am J Transplant, 11, n. 7, p. 1359-1367, Jul 2011. ISSN 1600-6143. Disponível em: < http://www.ncbi.nlm.nih.gov/pubmed/21668625 >.

COENEN, J. J.; KOENEN, H. J.; VAN RIJSSEN, E.; HILBRANDS, L. B. et al. Rapamycin, and not cyclosporin A, preserves the highly suppressive CD27+ subset of human CD4+CD25+ regulatory T cells. Blood, 107, n. 3, p. 1018-1023, Feb 2006. ISSN 0006-4971. Disponível em: < http://www.ncbi.nlm.nih.gov/pubmed/16210336 >.

COLONNA-ROMANO, G.; AQUINO, A.; BULATI, M.; DI LORENZO, G. et al. Memory B cell subpopulations in the aged. Rejuvenation Res, 9, n. 1, p. 149-152, 2006. ISSN 1549-1684. Disponível em: < http://www.ncbi.nlm.nih.gov/pubmed/16608412 >.

COLONNA-ROMANO, G.; BUFFA, S.; BULATI, M.; CANDORE, G. et al. B cells compartment in centenarian offspring and old people. Curr Pharm Des, 16, n. 6, p. 604-608, 2010. ISSN 1873-4286. Disponível em: < http://www.ncbi.nlm.nih.gov/pubmed/20388070 >.

COLVIN, R. B.; SMITH, R. N. Antibody-mediated organ-allograft rejection. Nat Rev Immunol, 5, n. 10, p. 807-817, Oct 2005. ISSN 1474-1733. Disponível em: < https://www.ncbi.nlm.nih.gov/pubmed/16175181 >.

DANOVITCH, G. Handbook of Kidney Transplantation. Sexta Edição. Philadelphia: Wolters Kluwer, 2017.

DANOVITCH, G. M.; GILL, J.; BUNNAPRADIST, S. Immunosuppression of the elderly kidney transplant recipient. Transplantation, 84, n. 3, p. 285-291, Aug 2007. ISSN 0041-1337. Disponível em: < http://www.ncbi.nlm.nih.gov/pubmed/17700150 >. 
DATASUS. Indicadores de morbidade e fatores de risco. 2008. Disponível em: \&amp;lt;span style=\&amp;quot;font-size:12.0pt Disponível em: mso-bidi-language:ARSA\&amp;quot;\&amp;gt;http://tabnet.datasus.gov.br/cgi/deftohtm.exe?idb2008/d22.def.

DAVID-NETO E, A. F., RAMOS F, TRIBONI A, ALTONA M, COELHO V, GALANTE N, LEMOS F. Everolimus/Low Tacrolimus(TAC) Compared to MPA/RegularTAC for Renal Transplantation in the Elderly Recipient - Preliminary Analysis of the nEverOld Trial. [abstract]. Am J Transplant. 16 (suppl 3) 2016.

DAVID-NETO, E.; AGENA, F.; RAMOS, F.; TRIBONI, A. H. et al. Longitudinal Pharmacokinetics of Everolimus when Combined with Low-level of Tacrolimus in Elderly Renal Transplant Recipients. Transplantation, Oct 2016. ISSN 1534-6080. Disponível em: < https://www.ncbi.nlm.nih.gov/pubmed/27798513 >.

DAVID-NETO, E.; ROMANO, P.; KAMADA TRIBONI, A. H.; RAMOS, F. et al. Longitudinal Pharmacokinetics of Tacrolimus in Elderly Compared With Younger Recipients in the First 6 Months After Renal Transplantation. Transplantation, 101, n. 6, p. 1365-1372, Jun 2017. ISSN 1534-6080. Disponível em: < https://www.ncbi.nlm.nih.gov/pubmed/27482958 >.

DE CASTRO, M. C. R.; BARBOSA, E. A.; SOUZA, R. P.; AGENA, F. et al. The Kinetics of Anti-HLA Antibodies in the First Year after Kidney Transplantation: In Whom and When Should They Be Monitored? J Transplant, 2018, p. 8316860, 2018. ISSN 2090-0007. Disponível em: < https://www.ncbi.nlm.nih.gov/pubmed/29850195 >.

DEMIRKIRAN, A.; SEWGOBIND, V. D.; VAN DER WEIJDE, J.; KOK, A. et al. Conversion from calcineurin inhibitor to mycophenolate mofetil-based immunosuppression changes the frequency and phenotype of CD4+FOXP3+ regulatory T cells. Transplantation, 87, n. 7, p. 1062-1068, Apr 2009. ISSN 1534-6080. Disponível em: < http://www.ncbi.nlm.nih.gov/pubmed/19352129 $>$.

DWYER, K. M.; HANIDZIAR, D.; PUTHETI, P.; HILL, P. A. et al. Expression of CD39 by human peripheral blood CD4+ CD25+ T cells denotes a regulatory memory phenotype. Am J Transplant, 10, n. 11, p. 2410-2420, Nov 2010. ISSN 1600-6143. Disponível em: < https://www.ncbi.nlm.nih.gov/pubmed/20977632 >.

EHRENSTEIN, M. R.; EVANS, J. G.; SINGH, A.; MOORE, S. et al. Compromised function of regulatory T cells in rheumatoid arthritis and reversal by anti-TNFalpha therapy. J Exp Med, 200, n. 3, p. 277-285, Aug 2004. ISSN 0022-1007. Disponível em: < http://www.ncbi.nlm.nih.gov/pubmed/15280421 >

EINECKE, G.; SIS, B.; REEVE, J.; MENGEL, M. et al. Antibody-mediated microcirculation injury is the major cause of late kidney transplant failure. Am J Transplant, 9, n. 11, p. 2520-2531, Nov 2009. ISSN 1600-6143. Disponível em: < http://www.ncbi.nlm.nih.gov/pubmed/19843030 >. 
EL-ZOGHBY, Z. M.; STEGALL, M. D.; LAGER, D. J.; KREMERS, W. K. et al. Identifying specific causes of kidney allograft loss. Am J Transplant, 9, n. 3, p. 527-535, Mar 2009. ISSN 1600-6143. Disponível em: < http://www.ncbi.nlm.nih.gov/pubmed/19191769 >.

FARIA, A. M.; DE MORAES, S. M.; DE FREITAS, L. H.; SPEZIALI, E. et al. Variation rhythms of lymphocyte subsets during healthy aging. Neuroimmunomodulation, 15, n. 4-6, p. 365-379, 2008. ISSN 1423-0216. Disponível em: < http://www.ncbi.nlm.nih.gov/pubmed/19047812 >.

FERGUSON, F. G.; WIKBY, A.; MAXSON, P.; OLSSON, J. et al. Immune parameters in a longitudinal study of a very old population of Swedish people: a comparison between survivors and nonsurvivors. J Gerontol A Biol Sci Med Sci, 50, n. 6, p. B378-382, Nov 1995. ISSN 1079-5006. Disponível em: < http://www.ncbi.nlm.nih.gov/pubmed/7583794 >.

FERNÁNDEZ-FRESNEDO, G.; RAMOS, M. A.; GONZÁLEZ-PARDO, M. C.; DE FRANCISCO, A. L. et al. B lymphopenia in uremia is related to an accelerated in vitro apoptosis and dysregulation of $\mathrm{BCl}-2$. Nephrol Dial Transplant, 15, n. 4, p. 502-510, Apr 2000. ISSN 0931-0509. Disponível em: < https://www.ncbi.nlm.nih.gov/pubmed/10727545 >.

FILLATREAU, S.; SWEENIE, C. H.; MCGEACHY, M. J.; GRAY, D. et al. B cells regulate autoimmunity by provision of IL-10. Nat Immunol, 3, n. 10, p. 944-950, Oct 2002. ISSN 1529-2908. Disponível em: < http://www.ncbi.nlm.nih.gov/pubmed/12244307 >.

FREITAS, G. R. R.; DA LUZ FERNANDES, M.; AGENA, F.; JALUUL, O. et al. Aging and End Stage Renal Disease Cause A Decrease in Absolute Circulating Lymphocyte Counts with A Shift to A Memory Profile and Diverge in Treg Population. Aging Dis, 10, n. 1, p. 49-61, Feb 2019. ISSN 2152-5250. Disponível em: <https://www.ncbi.nlm.nih.gov/pubmed/30705767 >.

GREGG, R.; SMITH, C. M.; CLARK, F. J.; DUNNION, D. et al. The number of human peripheral blood CD4+ CD25high regulatory T cells increases with age. Clin Exp Immunol, 140, n. 3, p. 540-546, Jun 2005. ISSN 0009-9104. Disponível em: < http://www.ncbi.nlm.nih.gov/pubmed/15932517>

GUBA, M.; VON BREITENBUCH, P.; STEINBAUER, M.; KOEHL, G. et al. Rapamycin inhibits primary and metastatic tumor growth by antiangiogenesis: involvement of vascular endothelial growth factor. Nat Med, 8, n. 2, p. 128-135, Feb 2002. ISSN 1078-8956. Disponível em: < http://www.ncbi.nlm.nih.gov/pubmed/11821896 >.

GUIJARRO, C.; MASSY, Z. A.; KASISKE, B. L. Clinical correlation between renal allograft failure and hyperlipidemia. Kidney Int Suppl, 52, p. S56-59, Dec 1995. ISSN 0098-6577. Disponível em: < http://www.ncbi.nlm.nih.gov/pubmed/8587285 >.

GURKAN, S.; LUAN, Y.; DHILLON, N.; ALLAM, S. R. et al. Immune reconstitution following rabbit antithymocyte globulin. Am J Transplant, 10, n. 9, p. 2132-2141, Sep 2010. ISSN 1600-6143. Disponível em: < http://www.ncbi.nlm.nih.gov/pubmed/20883548 >. 
HALLORAN, P. F. Immunosuppressive drugs for kidney transplantation. N Engl J Med, 351, n. 26, p. 2715-2729, Dec 2004. ISSN 1533-4406. Disponivel em: < http://www.ncbi.nlm.nih.gov/pubmed/15616206 >.

HALLORAN, P. F.; MELK, A.; BARTH, C. Rethinking chronic allograft nephropathy: the concept of accelerated senescence. J Am Soc Nephrol, 10, n. 1, p. 167-181, Jan 1999. ISSN 1046-6673. Disponível em: < http://www.ncbi.nlm.nih.gov/pubmed/9890324 >.

HART, A.; SMITH, J. M.; SKEANS, M. A.; GUSTAFSON, S. K. et al. OPTN/SRTR 2017 Annual Data Report: Kidney. Am J Transplant, 19 Suppl 2, p. 19-123, Feb 2019. ISSN 1600-6143. Disponível em: < https://www.ncbi.nlm.nih.gov/pubmed/30811893 >.

HE, X.; SMEETS, R. L.; KOENEN, H. J.; VINK, P. M. et al. Mycophenolic acid-mediated suppression of human CD4+ T cells: more than mere guanine nucleotide deprivation. Am J Transplant, 11, n. 3, p. 439449, Mar 2011. ISSN 1600-6143. Disponível em:<http://www.ncbi.nlm.nih.gov/pubmed/21342445 >.

HEIDT, S.; ROELEN, D. L.; EIJSINK, C.; VAN KOOTEN, C. et al. Effects of immunosuppressive drugs on purified human B cells: evidence supporting the use of MMF and rapamycin. Transplantation, 86, n. 9, p. 1292-1300, Nov 2008. ISSN 1534-6080. Disponível em: < http://www.ncbi.nlm.nih.gov/pubmed/19005412 >.

HELDAL, K.; HARTMANN, A.; GROOTENDORST, D. C.; DE JAGER, D. J. et al. Benefit of kidney transplantation beyond 70 years of age. Nephrol Dial Transplant, 25, n. 5, p. 1680-1687, May 2010. ISSN 1460-2385. Disponível em: < http://www.ncbi.nlm.nih.gov/pubmed/20038521 >.

HENDRIKX, T. K.; VAN GURP, E. A.; MOL, W. M.; SCHOORDIJK, W. et al. End-stage renal failure and regulatory activities of CD4+CD25bright+FoxP3+ T-cells. Nephrol Dial Transplant, 24, n. 6, p. 19691978, 2009. Disponível em:<https://www.ncbi.nlm.nih.gov/pubmed/19193737 >.

HENDRIKX, T. K.; VELTHUIS, J. H.; KLEPPER, M.; VAN GURP, E. et al. Monotherapy rapamycin allows an increase of CD4 CD25 FoxP3 T cells in renal recipients. Transpl Int, 22, n. 9, p. 884-891, Sep 2009. ISSN 1432-2277. Disponível em: <https://www.ncbi.nlm.nih.gov/pubmed/19453998 >.

HORI, S.; NOMURA, T.; SAKAGUCHI, S. Control of regulatory T cell development by the transcription factor Foxp3. Science, 299, n. 5609, p. 1057-1061, Feb 2003. ISSN 1095-9203. Disponível em: < http://www.ncbi.nlm.nih.gov/pubmed/12522256 >.

HOSONO, M.; DE BOER, O. J.; VAN DER WAL, A. C.; VAN DER LOOS, C. M. et al. Increased expression of T cell activation markers (CD25, CD26, CD40L and CD69) in atherectomy specimens of patients with unstable angina and acute myocardial infarction. Atherosclerosis, 168, n. 1, p. 73-80, May 2003. ISSN 0021-9150. Disponível em: < https://www.ncbi.nlm.nih.gov/pubmed/12732389 >. 
IBGE. Projeção da População do Brasil por sexo e idade: 2000-2060. 2014. Disponível em: http://www.ibge.gov.br/home/estatistica/populacao/projecao da populacao/2013/default tab.sht m. Acesso em: 01/03/2017.

JANEWAY, C. A.; RON, J.; KATZ, M. E. The B cell is the initiating antigen-presenting cell in peripheral lymph nodes. J Immunol, 138, n. 4, p. 1051-1055, Feb 1987. ISSN 0022-1767. Disponível em: < http://www.ncbi.nlm.nih.gov/pubmed/3100626 >.

JASSAL, S. V.; OPELZ, G.; COLE, E. Transplantation in the elderly: a review. Geriatr Nephrol Urol, 7, n. 3, p. 157-165, 1997. ISSN 0924-8455. Disponível em: < http://www.ncbi.nlm.nih.gov/pubmed/9493037 >.

KAMINSKI, D. A.; WEI, C.; QIAN, Y.; ROSENBERG, A. F. et al. Advances in human B cell phenotypic profiling. Front Immunol, 3, p. 302, 2012. ISSN 1664-3224. Disponível em: < http://www.ncbi.nlm.nih.gov/pubmed/23087687 >.

KARNELL, J. L.; KARNELL, F. G.; STEPHENS, G. L.; RAJAN, B. et al. Mycophenolic acid differentially impacts B cell function depending on the stage of differentiation. J Immunol, 187, n. 7, p. 3603-3612, Oct 2011. ISSN 1550-6606. Disponível em: < http://www.ncbi.nlm.nih.gov/pubmed/21873529 >.

KAUFFMAN, H. M.; CHERIKH, W. S.; CHENG, Y.; HANTO, D. W. et al. Maintenance immunosuppression with target-of-rapamycin inhibitors is associated with a reduced incidence of de novo malignancies. Transplantation, 80, n. 7, p. 883-889, Oct 2005. ISSN 0041-1337. Disponível em: < http://www.ncbi.nlm.nih.gov/pubmed/16249734 >.

KHO, M. M.; BOUVY, A. P.; CADOGAN, M.; KRAAIJEVELD, R. et al. The effect of low and ultra-low dosages Thymoglobulin on peripheral T, B and NK cells in kidney transplant recipients. Transpl Immunol, 26, n. 4, p. 186-190, Jun 2012. ISSN 1878-5492. Disponível em: < http://www.ncbi.nlm.nih.gov/pubmed/22410573 >.

KIM, K. W.; CHUNG, B. H.; JEON, E. J.; KIM, B. M. et al. B cell-associated immune profiles in patients with end-stage renal disease (ESRD). Exp Mol Med, 44, n. 8, p. 465-472, Aug 2012. ISSN 2092-6413. Disponível em: < https://www.ncbi.nlm.nih.gov/pubmed/22617684 >.

KLEIN, U.; RAJEWSKY, K.; KÜPPERS, R. Human immunoglobulin (Ig)M+lgD+ peripheral blood B cells expressing the CD27 cell surface antigen carry somatically mutated variable region genes: CD27 as a general marker for somatically mutated (memory) B cells. J Exp Med, 188, n. 9, p. 1679-1689, Nov 1998. ISSN 0022-1007. Disponível em: < http://www.ncbi.nlm.nih.gov/pubmed/9802980 >.

KOCH, S.; LARBI, A.; DERHOVANESSIAN, E.; OZCELIK, D. et al. Multiparameter flow cytometric analysis of CD4 and CD8 T cell subsets in young and old people. Immun Ageing, 5, p. 6, 2008. ISSN 1742-4933. Disponível em: < http://www.ncbi.nlm.nih.gov/pubmed/18657274 >. 
KOGINA, K.; SHODA, H.; YAMAGUCHI, Y.; TSUNO, N. H. et al. Tacrolimus differentially regulates the proliferation of conventional and regulatory CD4(+) T cells. Mol Cells, 28, n. 2, p. 125-130, Aug 2009. ISSN 0219-1032. Disponível em: < http://www.ncbi.nlm.nih.gov/pubmed/19714314 >.

KRENSKY, A. M.; WEISS, A.; CRABTREE, G.; DAVIS, M. M. et al. T-lymphocyte-antigen interactions in transplant rejection. N Engl J Med, 322, n. 8, p. 510-517, Feb 1990. ISSN 0028-4793. Disponível em: < http://www.ncbi.nlm.nih.gov/pubmed/2405272 >.

KRYSTUFKOVA, E.; SEKERKOVA, A.; STRIZ, I.; BRABCOVA, l. et al. Regulatory T cells in kidney transplant recipients: the effect of induction immunosuppression therapy. Nephrol Dial Transplant, 27, n. 6, p. 2576-2582, Jun 2012. ISSN 1460-2385. Disponível em: < http://www.ncbi.nlm.nih.gov/pubmed/22167587 >.

KUMBALA, D.; ZHANG, R. Essential concept of transplant immunology for clinical practice. World J Transplant, 3, n. 4, p. 113-118, Dec 2013. ISSN 2220-3230. Disponível em: < http://www.ncbi.nlm.nih.gov/pubmed/24392315 >.

LATORRE, I.; ESTEVE-SOLE, A.; REDONDO, D.; GIEST, S. et al. Calcineurin and mTOR inhibitors have opposing effects on regulatory $T$ cells while reducing regulatory $B$ cell populations in kidney transplant recipients. Transpl Immunol, 35, p. 1-6, Mar 2016. ISSN 1878-5492. Disponível em: < https://www.ncbi.nlm.nih.gov/pubmed/26836476 >.

LECHLER, R. I.; BATCHELOR, J. R. Restoration of immunogenicity to passenger cell-depleted kidney allografts by the addition of donor strain dendritic cells. J Exp Med, 155, n. 1, p. 31-41, Jan 1982. ISSN 0022-1007. Disponível em: < http://www.ncbi.nlm.nih.gov/pubmed/7033437 >.

LEFEBVRE, J. S.; HAYNES, L. Aging of the CD4 T Cell Compartment. Open Longev Sci, 6, p. 83-91, Jan 2012. ISSN 1876-326X. Disponível em: < http://www.ncbi.nIm.nih.gov/pubmed/24839469 >.

LEIBLER, C.; MATIGNON, M.; PILON, C.; MONTESPAN, F. et al. Kidney transplant recipients treated with belatacept exhibit increased naïve and transitional B cells. Am J Transplant, 14, n. 5, p. 1173-1182, May 2014. ISSN 1600-6143. Disponível em: < https://www.ncbi.nlm.nih.gov/pubmed/24730563 >.

LIN, W. X.; CHRISTIANSEN, D.; FU, L. L.; ROBERTS, M. A. et al. Foxp3+ T cells in peripheral blood of renal transplant recipients and clinical correlations. Nephrology (Carlton), 17, n. 4, p. 415-422, May 2012. ISSN 1440-1797. Disponível em: < https://www.ncbi.nlm.nih.gov/pubmed/22308996 >.

LINDLEY, S.; DAYAN, C. M.; BISHOP, A.; ROEP, B. O. et al. Defective suppressor function in CD4(+)CD25(+) T-cells from patients with type 1 diabetes. Diabetes, 54, n. 1, p. 92-99, Jan 2005. ISSN 0012-1797. Disponível em: < http://www.ncbi.nlm.nih.gov/pubmed/15616015 >.

LISOWSKA, K. A.; DĘBSKA-ŚLIZIEŃ, A.; JASIULEWICZ, A.; BRYL, E. et al. Influence of hemodialysis on circulating CD4(low)CD25 (high) regulatory $T$ cells in end-stage renal disease patients. Inflamm Res, 
63, n. 2, p. 99-103, Feb 2014. ISSN 1420-908X. Disponível em: < https://www.ncbi.nlm.nih.gov/pubmed/24189710 >.

LITJENS, N. H.; VAN DRUNINGEN, C. J.; BETJES, M. G. Progressive loss of renal function is associated with activation and depletion of naive T lymphocytes. Clin Immunol, 118, n. 1, p. 83-91, 2006. Disponível em: < https://www.ncbi.nlm.nih.gov/pubmed/16257266 >.

LIU, W.; PUTNAM, A. L.; XU-YU, Z.; SZOT, G. L. et al. CD127 expression inversely correlates with FoxP3 and suppressive function of human CD4+ T reg cells. J Exp Med, 203, n. 7, p. 1701-1711, Jul 2006. ISSN 0022-1007. Disponível em: < http://www.ncbi.nlm.nih.gov/pubmed/16818678>.

LOPEZ, M.; CLARKSON, M. R.; ALBIN, M.; SAYEGH, M. H. et al. A novel mechanism of action for antithymocyte globulin: induction of CD4+CD25+Foxp3+ regulatory T cells. J Am Soc Nephrol, 17, n. 10, p. 2844-2853, Oct 2006. ISSN 1046-6673. Disponível em: < http://www.ncbi.nlm.nih.gov/pubmed/16914538 >.

LYNCH, H. E.; GOLDBERG, G. L.; CHIDGEY, A.; VAN DEN BRINK, M. R. et al. Thymic involution and immune reconstitution. Trends Immunol, 30, n. 7, p. 366-373, 2009. Disponível em: < https://www.ncbi.nlm.nih.gov/pubmed/19540807 >.

MA, L.; LIU, B.; JIANG, Z.; JIANG, Y. Reduced numbers of regulatory B cells are negatively correlated with disease activity in patients with new-onset rheumatoid arthritis. Clin Rheumatol, 33, n. 2, p. 187195, Feb 2014. ISSN 1434-9949. Disponível em: < http://www.ncbi.nlm.nih.gov/pubmed/23949637 >.

MANDELBROT, D. Transplantation Immunobiology. In: DANOVITCH, G. (Ed.). Handbook of Kidney Transplantation. 5 ed. Philadelphia: Lippincott Williams \&amp; Wilkins, 2010. v. 1, cap. 2, p. 19-35.

MATAS, A. J.; SMITH, J. M.; SKEANS, M. A.; THOMPSON, B. et al. OPTN/SRTR 2012 Annual Data Report: kidney. Am J Transplant, 14 Suppl 1, p. 11-44, Jan 2014. ISSN 1600-6143. Disponível em: < https://www.ncbi.nlm.nih.gov/pubmed/24373166 >.

MAURI, C.; BLAIR, P. A. Regulatory B cells in autoimmunity: developments and controversies. Nat Rev Rheumatol, 6, n. 11, p. 636-643, Nov 2010. ISSN 1759-4804. Disponível em: < https://www.ncbi.nlm.nih.gov/pubmed/20856268 >.

MCLAREN, A. J.; FUGGLE, S. V.; WELSH, K. I.; GRAY, D. W. et al. Chronic allograft failure in human renal transplantation: a multivariate risk factor analysis. Ann Surg, 232, n. 1, p. 98-103, Jul 2000. ISSN 00034932. Disponível em: <http://www.ncbi.nlm.nih.gov/pubmed/10862201 >.

MEIER-KRIESCHE, H. U.; KAPLAN, B. Immunosuppression in elderly renal transplant recipients: are current regimens too aggressive? Drugs Aging, 18, n. 10, p. 751-759, 2001. ISSN 1170-229X. Disponível em: < http://www.ncbi.nlm.nih.gov/pubmed/11735622 >. 
MEIER-KRIESCHE, H. U.; OJO, A.; HANSON, J.; CIBRIK, D. et al. Increased immunosuppressive vulnerability in elderly renal transplant recipients. Transplantation, 69, n. 5, p. 885-889, Mar 2000. ISSN 0041-1337. Disponível em: < http://www.ncbi.nlm.nih.gov/pubmed/10755545 >.

MEIER-KRIESCHE, H. U.; OJO, A. O.; CIBRIK, D. M.; HANSON, J. A. et al. Relationship of recipient age and development of chronic allograft failure. Transplantation, 70, n. 2, p. 306-310, Jul 2000. ISSN 00411337. Disponível em: < http://www.ncbi.nlm.nih.gov/pubmed/10933154 >.

MEIJERS, R. W.; LITJENS, N. H.; DE WIT, E. A.; LANGERAK, A. W. et al. Uremia causes premature ageing of the T cell compartment in end-stage renal disease patients. Immun Ageing, 9, n. 1, p. 19, Sep 2012. ISSN 1742-4933. Disponível em: < https://www.ncbi.nlm.nih.gov/pubmed/22971545 >.

MIROUX, C.; MORALES, O.; GHAZAL, K.; OTHMAN, S. B. et al. In vitro effects of cyclosporine A and tacrolimus on regulatory T-cell proliferation and function. Transplantation, 94, n. 2, p. 123-131, Jul 2012. ISSN 1534-6080. Disponível em: < http://www.ncbi.nlm.nih.gov/pubmed/22743548 >.

MORBACH, H.; EICHHORN, E. M.; LIESE, J. G.; GIRSCHICK, H. J. Reference values for B cell subpopulations from infancy to adulthood. Clin Exp Immunol, 162, n. 2, p. 271-279, Nov 2010. ISSN 1365-2249. Disponível em: < http://www.ncbi.nlm.nih.gov/pubmed/20854328 >.

MORELON, E.; LEFRANÇOIS, N.; BESSON, C.; PRÉVAUTEL, J. et al. Preferential increase in memory and regulatory subsets during T-lymphocyte immune reconstitution after Thymoglobulin induction therapy with maintenance sirolimus vs cyclosporine. Transpl Immunol, 23, n. 1-2, p. 53-58, May 2010. ISSN 1878-5492. Disponível em: < http://www.ncbi.nlm.nih.gov/pubmed/20406686 >.

MORO-GARCÍA, M. A.; ALONSO-ARIAS, R.; LÓPEZ-LARREA, C. Molecular mechanisms involved in the aging of the T-cell immune response. Curr Genomics, 13, n. 8, p. 589-602, Dec 2012. ISSN 1389-2029. Disponível em: <https://www.ncbi.nlm.nih.gov/pubmed/23730199 >.

MORO-GARCÍA, M. A.; ALONSO-ARIAS, R.; LÓPEZ-LARREA, C. When Aging Reaches CD4+ T-Cells: Phenotypic and Functional Changes. Front Immunol, 4, p. 107, 2013. ISSN 1664-3224. Disponível em: < http://www.ncbi.nlm.nih.gov/pubmed/23675374 >.

NAESENS, M.; KUYPERS, D. R.; DE VUSSER, K.; EVENEPOEL, P. et al. The histology of kidney transplant failure: a long-term follow-up study. Transplantation, 98, n. 4, p. 427-435, Aug 2014. ISSN 1534-6080. Disponível em: <http://www.ncbi.nlm.nih.gov/pubmed/25243513 $>$.

NAYLOR, K.; LI, G.; VALLEJO, A. N.; LEE, W. W. et al. The influence of age on T cell generation and TCR diversity. J Immunol, 174, n. 11, p. 7446-7452, 2005. Disponível em: < https://www.ncbi.nlm.nih.gov/pubmed/15905594 >.

OPELZ, G.; WUJCIAK, T.; RITZ, E. Association of chronic kidney graft failure with recipient blood pressure. Collaborative Transplant Study. Kidney Int, 53, n. 1, p. 217-222, Jan 1998. ISSN 0085-2538. Disponível em: < http://www.ncbi.nlm.nih.gov/pubmed/9453022 >. 
PAHL, M. V.; GOLLAPUDI, S.; SEPASSI, L.; GOLLAPUDI, P. et al. Effect of end-stage renal disease on Blymphocyte subpopulations, IL-7, BAFF and BAFF receptor expression. Nephrol Dial Transplant, 25, n. 1 p. 205-212, Jan 2010. ISSN 1460-2385. Disponível em: < https://www.ncbi.nlm.nih.gov/pubmed/19684120 >.

PAOLETTI, E.; AMIDONE, M.; CASSOTTANA, P.; GHERZI, M. et al. Effect of sirolimus on left ventricular hypertrophy in kidney transplant recipients: a 1-year nonrandomized controlled trial. Am J Kidney Dis, 52, n. 2, p. 324-330, Aug 2008. ISSN 1523-6838. Disponível em: < http://www.ncbi.nlm.nih.gov/pubmed/18585837 >.

PASCUAL, J.; BERGER, S. P.; WITZKE, O.; TEDESCO, H. et al. Everolimus with Reduced Calcineurin Inhibitor Exposure in Renal Transplantation. J Am Soc Nephrol, 29, n. 7, p. 1979-1991, Jul 2018. Disponível em: < https://www.ncbi.nlm.nih.gov/pubmed/29752413 >.

PASCUAL, V.; LIU, Y. J.; MAGALSKI, A.; DE BOUTEILLER, O. et al. Analysis of somatic mutation in five B cell subsets of human tonsil. J Exp Med, 180, n. 1, p. 329-339, Jul 1994. ISSN 0022-1007. Disponível em: < http://www.ncbi.nlm.nih.gov/pubmed/8006591 >.

POPOW, I.; LEITNER, J.; GRABMEIER-PFISTERSHAMMER, K.; MAJDIC, O. et al. A comprehensive and quantitative analysis of the major specificities in rabbit antithymocyte globulin preparations. Am J Transplant, 13, n. 12, p. 3103-3113, Dec 2013. ISSN 1600-6143. Disponível em: < https://www.ncbi.nlm.nih.gov/pubmed/24168235 >

POULTON, T. A.; GALLAGHER, A.; POTTS, R. C.; BECK, J. S. Changes in activation markers and cell membrane receptors on human peripheral blood $\mathrm{T}$ lymphocytes during cell cycle progression after $\mathrm{PHA}$ stimulation. Immunology, 64, n. 3, p. 419-425, Jul 1988. ISSN 0019-2805. Disponível em: < https://www.ncbi.nlm.nih.gov/pubmed/3261709 >.

ROMANO, P.; AGENA, F.; DE ALMEIDA REZENDE EBNER, P.; MASSAKAZU SUMITA, N. et al. Longitudinal Pharmacokinetics of Mycophenolic Acid in Elderly Renal Transplant Recipients Compared to a Younger Control Group: Data from the nEverOld Trial. Eur J Drug Metab Pharmacokinet, 44, n. 2, p. 189-199, 04 2019. ISSN 2107-0180. Disponível em: < https://www.ncbi.nlm.nih.gov/pubmed/30229398 >.

RON, Y.; SPRENT, J. T cell priming in vivo: a major role for B cells in presenting antigen to T cells in lymph nodes. J Immunol, 138, n. 9, p. 2848-2856, May 1987. ISSN 0022-1767. Disponível em: < http://www.ncbi.nlm.nih.gov/pubmed/2952725 >.

SAN SEGUNDO, D.; FERNÁNDEZ-FRESNEDO, G.; RUIZ, J. C.; RODRIGO, E. et al. Two-year follow-up of a prospective study of circulating regulatory $T$ cells in renal transplant patients. Clin Transplant, 24, n. 3, p. 386-393, 2010 May-Jun 2010. ISSN 1399-0012. Disponível em: < http://www.ncbi.nlm.nih.gov/pubmed/19744094 >.

SANKATSING, S. U.; PRINS, J. M.; YONG, S. L.; ROELOFSEN, J. et al. Mycophenolate mofetil inhibits Tcell proliferation in kidney transplant recipients without lowering intracellular dGTP and GTP. Transpl 
Int, 21, n. 11, p. 1066-1071, Nov 2008. ISSN 0934-0874. Disponível em: < http://www.ncbi.nlm.nih.gov/pubmed/18699845 >.

SANZ, I.; WEI, C.; LEE, F. E.; ANOLIK, J. Phenotypic and functional heterogeneity of human memory B cells. Semin Immunol, 20, n. 1, p. 67-82, Feb 2008. ISSN 1044-5323. Disponível em: < http://www.ncbi.nlm.nih.gov/pubmed/18258454 >.

SARAN, R.; ROBINSON, B.; ABBOTT, K. C.; AGODOA, L. Y. et al. US Renal Data System 2016 Annual Data Report: Epidemiology of Kidney Disease in the United States. Am J Kidney Dis, 69, n. 3S1, p. A7-A8, Mar 2017. ISSN 1523-6838. Disponível em: < https://www.ncbi.nlm.nih.gov/pubmed/28236831 >.

SAULE, P.; TRAUET, J.; DUTRIEZ, V.; LEKEUX, V. et al. Accumulation of memory T cells from childhood to old age: central and effector memory cells in $\mathrm{CD} 4(+)$ versus effector memory and terminally differentiated memory cells in CD8(+) compartment. Mech Ageing Dev, 127, n. 3, p. 274-281, Mar 2006. Disponível em:< http://www.ncbi.nlm.nih.gov/pubmed/16352331 >

SAYEGH, M. H.; TURKA, L. A. The role of T-cell costimulatory activation pathways in transplant rejection. N Engl J Med, 338, n. 25, p. 1813-1821, Jun 1998. ISSN 0028-4793. Disponível em: < http://www.ncbi.nlm.nih.gov/pubmed/9632449 >.

SCOTTÀ, C.; ESPOSITO, M.; FAZEKASOVA, H.; FANELLI, G. et al. Differential effects of rapamycin and retinoic acid on expansion, stability and suppressive qualities of human CD4(+)CD25(+)FOXP3(+) T regulatory cell subpopulations. Haematologica, 98, n. 8, p. 1291-1299, Aug 2013. ISSN 1592-8721. Disponível em: < https://www.ncbi.nlm.nih.gov/pubmed/23242600 >.

SEWGOBIND, V. D.; KHO, M. M.; VAN DER LAAN, L. J.; HENDRIKX, T. K. et al. The effect of rabbit antithymocyte globulin induction therapy on regulatory $T$ cells in kidney transplant patients. Nephrol Dial Transplant, 24, n. 5, p. 1635-1644, May 2009. ISSN 1460-2385. Disponível em: < http://www.ncbi.nlm.nih.gov/pubmed/19176684 >.

SHABIR, S.; GIRDLESTONE, J.; BRIGGS, D.; KAUL, B. et al. Transitional B lymphocytes are associated with protection from kidney allograft rejection: a prospective study. Am J Transplant, 15, n. 5, p. 1384-1391, May 2015. ISSN 1600-6143. Disponível em: < https://www.ncbi.nlm.nih.gov/pubmed/25808898 >.

SILVA, H. M.; TAKENAKA, M. C.; MORAES-VIEIRA, P. M.; MONTEIRO, S. M. et al. Preserving the B-cell compartment favors operational tolerance in human renal transplantation. Mol Med, 18, p. 733-743, 2012. ISSN 1528-3658. Disponível em: < http://www.ncbi.nlm.nih.gov/pubmed/22252714 >.

SIMONE, R.; ZICCA, A.; SAVERINO, D. The frequency of regulatory CD3+CD8+CD28- CD25+ T lymphocytes in human peripheral blood increases with age. J Leukoc Biol, 84, n. 6, p. 1454-1461, Dec 2008. ISSN 0741-5400. Disponível em: < http://www.ncbi.nlm.nih.gov/pubmed/18780874 >.

STRINDHALL, J.; NILSSON, B. O.; LÖFGREN, S.; ERNERUDH, J. et al. No Immune Risk Profile among individuals who reach 100 years of age: findings from the Swedish NONA immune longitudinal study. 
Exp Gerontol, 42, n. 8, p. 753-761, Aug 2007. ISSN 0531-5565. Disponível em: < http://www.ncbi.nlm.nih.gov/pubmed/17606347 >.

TANG, Q.; LEUNG, J.; MELLI, K.; LAY, K. et al. Altered balance between effector T cells and FOXP3+ HELIOS+ regulatory T cells after thymoglobulin induction in kidney transplant recipients. Transpl Int, 25, n. 12, p. 1257-1267, Dec 2012. ISSN 1432-2277. Disponível em: < http://www.ncbi.nlm.nih.gov/pubmed/22994802 >.

VENERI, D.; FRANCHINI, M.; VELLA, A.; TRIDENTE, G. et al. Changes of human B and B-1a peripheral blood lymphocytes with age. Hematology, 12, n. 4, p. 337-341, Aug 2007. ISSN 1607-8454. Disponível em: < http://www.ncbi.nlm.nih.gov/pubmed/17654062 >.

WARRENS, A. N.; LOMBARDI, G.; LECHLER, R. I. Presentation and recognition of major and minor histocompatibility antigens. Transpl Immunol, 2, n. 2, p. 103-107, Jun 1994. ISSN 0966-3274. Disponível em: < http://www.ncbi.nlm.nih.gov/pubmed/7953301 >.

YANG, J.; BROOK, M. O.; CARVALHO-GASPAR, M.; ZHANG, J. et al. Allograft rejection mediated by memory T cells is resistant to regulation. Proc Natl Acad Sci U S A, 104, n. 50, p. 19954-19959, Dec 2007. ISSN 1091-6490. Disponível em: < https://www.ncbi.nlm.nih.gov/pubmed/18042727 >.

YOON, J. W.; GOLLAPUDI, S.; PAHL, M. V.; VAZIRI, N. D. Naïve and central memory T-cell lymphopenia in end-stage renal disease. Kidney Int, 70, n. 2, p. 371-376, Jul 2006. ISSN 0085-2538. Disponível em: < https://www.ncbi.nlm.nih.gov/pubmed/16738532 >.

ZAND, M. S. B-cell activity of polyclonal antithymocyte globulins. Transplantation, 82, n. 11, p. 13871395, Dec 2006. ISSN 0041-1337. Disponível em: < http://www.ncbi.nlm.nih.gov/pubmed/17164703 $>$.

ZAND, M. S.; VO, T.; HUGGINS, J.; FELGAR, R. et al. Polyclonal rabbit antithymocyte globulin triggers Bcell and plasma cell apoptosis by multiple pathways. Transplantation, 79, n. 11, p. 1507-1515, Jun 2005. ISSN 0041-1337. Disponível em: < http://www.ncbi.nlm.nih.gov/pubmed/15940039 >.

ZARKHIN, V.; KAMBHAM, N.; LI, L.; KWOK, S. et al. Characterization of intra-graft B cells during renal allograft rejection. Kidney Int, 74, n. 5, p. 664-673, Sep 2008. ISSN 1523-1755. Disponível em: < https://www.ncbi.nlm.nih.gov/pubmed/18547992 >. 
Apêndices 


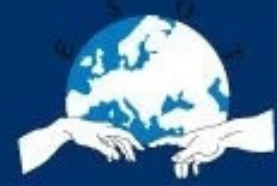

Official Journal of the European Society for Organ Transplantation,

the European Liver and Intestine Transplant Association and the German Transplantation Society
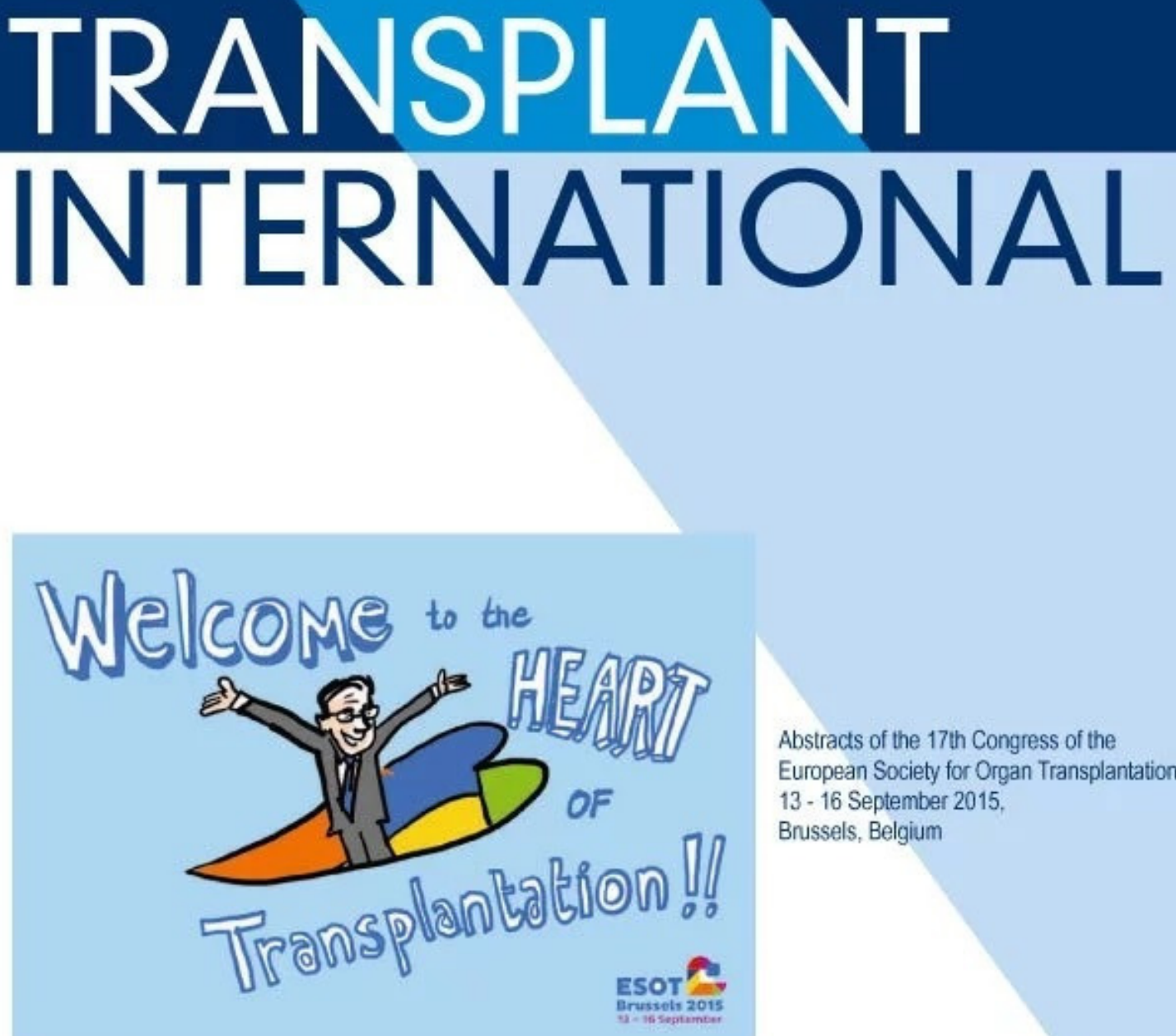

Abstracts of the 17th Congress of the

European Society for Organ Transplantation

13 - 16 September 2015 ,

Brussels, Belgium

\section{Disponível em:}

https://onlinelibrary.wiley.com/toc/14322277/2015/28/S4

WILEY

Blackwell 
003 CLINICAL IMMUNOSUPPRESSION \& BIOLOGICALS

\section{P599 TACROLIMUS ASSOCIATED BY EVEROLIMUS OR MYCOPHENOLIC ACID IN ELDERLY RENAL TRANSPLANT RECIPIENTS BY THE UPLC-LCMS/MS}

Paschoalina Romano ${ }^{1}$, Fabiana Agena ${ }^{1}$, Persio A. R. Ebner ${ }^{1}$, Francine Brambate Carvalhinho Lemos ${ }^{1}$, Nairo M. Sumita ${ }^{1}$, Maria E. Mendes ${ }^{1}$, Nilo Duarte $^{1}$, Elias David-Neto ${ }^{1}$, Geraldo Freitas ${ }^{2}$

${ }^{1}$ Hospital das Clinicas FMUSP; ${ }^{2}$ Hospital das Clinicas da Faculdade de Medicina da Universidade de São Paulo

Introduction: Tacrolimus is indispensable to maintain stable levels of these drugs, avoiding graft rejection. Low lewel or toxicity in high level it is important individual treatment. Everolimus facilitated reduction of Tacrolimus concentrations to levels below those previously investigated, with low rates of biopsyproven acute rejection (BPAR) and graft loss.
Objective: The aim of this study was to evaluate the analytical performance of Tacrolimus (TAC) UPLC-MS/MS in human whole blood of elderly transplant recipients associated by Everolimus (EVL) or enteric-coated mycophenolate sodium (EC-MPS)

Materials and Methods: Specime collection in EDTA whole blood tubes collection. Sample preparation of Whole blood standards, controls and patient samples $(50 \mu \mathrm{l})$ were treated with $0.1 \mathrm{~m}$ zinc sulphate) in methanol $(20 \mu \mathrm{l})$ and acetonitrile $(500 \mu \mathrm{l})$, vortexed for $1 \mathrm{~min}$, centrifuged $(5 \mathrm{~min}$ at $800 \mathrm{~g})$ and supernatant was injected $(20 \mu \mathrm{l})$. An initial evaluation was performed on the TAC, EVL and EC-MPS in UPLC-MS/MS method included precision, accuracy and analytical reportable range. We analyses $12 \mathrm{~h}$ pharmacokinetics (PK) (0 to 720 min.) of total TAC, EVL and EC-MPS in 38 elderly renal recipients (6171 years range). They are randomized by group TAC/ EVL and TAC/ EC-MPS. They had a measured after three months of renal transplantation. The analyses of the PK revealed the area under the curve to TAC/EC-MPS group were $\mathrm{AUC}=125.9 \pm 73.9 \mathrm{ng} . \mathrm{h} / \mathrm{ml}$ and $\mathrm{Cmax}$ were $17.50 \pm 12.5 \mathrm{ng} / \mathrm{ml}$ and TAC/ EVL group $A U C=102.8 \pm 52.99 \mathrm{ng} . \mathrm{h} / \mathrm{ml}$ and Cmax were $14.27 \pm 10.35 \mathrm{ng} /$ $\mathrm{ml}(\mathrm{p}>0.05)$

Conclusion: Tacrolimus in the human whole blood is not statically different when associated by Everolimus or MPA in elderly stable recipients. 


\section{Resumos dos trabalhos apresentados no:}

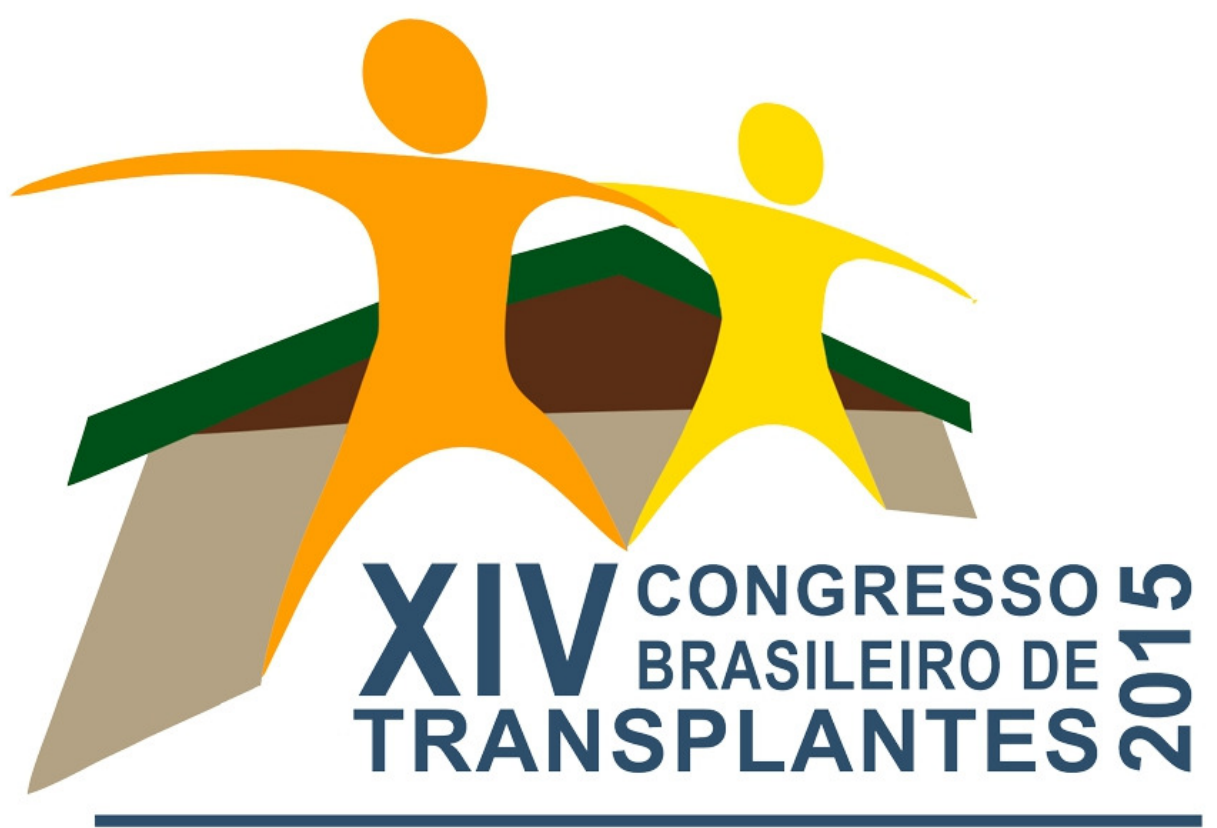

XIV Congresso Luso-Brasileiro de Transplantes XIII Encontro de Enfermagem em Transplantes V Encontro Multi Disciplinar em Transplantes Fórum de Histocompatibilidade da ABH

Disponível em:

http://congressoabto.org.br/2015/trabalhos/anais-congressoabto-gramado-2015.pdf

\section{ANAIS}


ORAL 088 Everolimo versus micofenolato em receptores de transplante renal de doadores com critérios expandidos (DCE) recebendo globulina anti- timócito e tacrolimo

ÁREA: RIM

INSTITUIÇÃO:

Hospital do Rim, Universidade Federal de São Paulo

\author{
AUTORES: \\ Tedesco-Silva, Hélio \\ Ferreira, Alexandra N \\ Cristelli, Marina $\mathrm{P}$ \\ Viana, Laila A \\ Basso, Geovana \\ Felix, Maria Júlia $\mathrm{P}$ \\ Hiramoto, Liliane L \\ Aguiar, Wilson $\mathrm{F}$ \\ Franco, Marcello F \\ Felipe, Claudia R \\ Medina-Pestana, José
}

Introdução: Receptores de rins de doadores expandidos apresentam elevado risco para função tardia do enxerto (FTE) e rejeição aguda (RA). O regime imunossupressor ideal para esses pacientes ainda não foi definido. Objetivos: comparar a eficácia e segurança de everolimo e micofenolato em receptores de transplante de DCE que receberam indução com globulina anti timócito (rATG), tacrolimo e prednisona. Métodos: Estudo prospectivo, randomizado, de centro único desenhado para inclusão de 200 pacientes (1:1) para receber terapia de indução com rATG, prednisona e introdução tardia de tacrolimo (dia 7) e everolimo (grupo EVR) ou micofenolato sódico (grupo MPS). Análises preliminares foram realizadas com 84 pacientes randomizados ( $N=44$, EVR $\mathrm{e}$ $\mathrm{N}=40$, MPS). Estratégia preemptiva foi utilizada para infecção de CMV. Resultados: Não houve diferença na média do índice de perfil do doador do rim (KDPI), e na média do índice de risco do doador do rim (KDRI), comparando os grupos EVR e MPS. Não houve diferença nas principais características demográficas, exceto na incidência de diabetes melitus. Não houve diferença na incidência de FTE, mas uma tendência para menor duração de FTE $(98 \pm 75$ vs $65 \pm 51$ dias, $p=0057)$ no grupo MPS. A incidência do primeiro episódio de infecção por CMV foi menor no grupo EVR (13 vs $87 \%, p=0,000)$. Além disso, $43 \%$ dos pacientes do grupo MPS com CMV desenvolveram pelo menos um evento de recorrência de CMV. Elevada incidência de RA tratada ou RA confirmada por biópsia foi observada no grupo EVR. Não houve diferença na função renal com 6 meses de seguimento. Conclusões: Essa análise preliminar indica que pacientes recebendo EVR apresentam menor risco para infecção por CMV, mas uma tendência de maior incidência de RA comparados aos pacientes tratados com MPS.

\section{ORAL 089 Análise comparativa de subpopulações linfocitárias T e B de idosos transplantados renais antes do transplante}

\section{ÁREA: RIM}

INSTITUIÇÃO:

Universidade de

São Paulo - USP

\section{AUTORES: \\ Galante, NZ \\ Freitas, GRR \\ Agena, $F$ \\ Triboni, AHK \\ Ramos, $F$ \\ Fernandes, ML \\ Colenci, S \\ Jabuul, O \\ Jacob-Filho, $\mathrm{W}$ \\ Coelho, $\mathrm{V}$ \\ David-Neto, E}

Não há estudos de caracterização de subpopulações(Subpop) de linfócitos(Linf) em idosos(Id) receptores de transplante renal(TxR), objetivo deste estudo. Caracterizamos as Subpop de linf em Id antes do TxR(IdTxR,65 $\pm 4 a, n=9)$ comparando os resultados com receptores não Id antes do TxR(nldTxR; $32 \pm 7 a, n=9)$, não idosos saudáveis(nldS, $25 \pm 2 a, n=11)$ e Id saudáveis(IdS, $79 \pm 6 a, n=5)$. Determinamos por citometria as populações de Linf: T CD4+ naïve (TN)(CD4+CD45RA+CCR7+), T CD4+ memória central (MC)(CD45RA-CCR7+), T CD4+ memória efetora (ME)(CD45RA-CCR7-), T CD8+ memória efetora RA+ (TEMRA)(CD4-CD45RA+CCR7-), T reguladora (Treg) (CD4+CD25+CD127loFOXP3+), B reguladora (Breg)(CD24hiCD38hi). A contagem de Linf foi menor em IdTxR que em nldS (1517vs2372 cels $/ \mathrm{mm} 3 ; p<0,05)$, e que em IdS e nldTxR (1517vs2044vs2296 cels/mm3, p=NS) IdTxR apresentaram menor população TN que nldTxR, IdS e nldS (9vs16vs 25 vs24 \%,p<0,05) IdTxR comparados a nldS apresentaram maior frequência de ME (59vs29\%,p<0,05) e TEMRA (82vs61 $\%, p<0,05)$ IdTxR tendiam a maior população ME (59vs42vs42\%, $p=N S$ ) e TEMRA (82vs80vs77 \%,p=NS) comparado a nIdTxR e IdS IdTxR apresentaram frequência de MC similar a nldTxR (6vs5 \%) e tendendo a menor que IdS e nldS (5vs9vs7 \%, p=NS) IdTxR apresentaram frequência de Treg comparável aos outros grupos, e frequência de Breg similar a nIdTxR (7vs7,8 \%,p=NS) e tendendo a maior que IdS e nldS (7vs5,9vs5,8 $\%, p=N S$ ). Os IdTxR apresentaram menor população de Linf totais, menor percentual de TN, maior frequência de ME e TEMRA, mas frequência semelhante de Treg IdTxR apresentaram maior população Breg comparado a IdS e nldS, mas semelhante a nldTxR Os IdTxR apresentam composição de Subpop linfocitárias de outros grupos, ressaltando a importância de avaliar diferentes esquemas imunossupressores. 


\section{Transplante renal em receptores idosos: comparação de resultados entre doadores vivos e falecidos}

ÁREA: RIM

INSTITUIÇÃO:

Hospital U̧niversitário

Ciências Médicas

(HUCM) / Faculdade

de Ciências Médicas

de Minas Gerais

(FCMMG) / Fundação

Educacional Lucas

Machado (FELUMA)

\section{AUTORES:}

Trindade, LGF

Lasmar, MF

Giordano, LFC

Vianna, HR

Reis, FCL, Cunha, OC

Lasmar, EP
Introdução: Pacientes idosos representam um terço da população em diálise no Brasil. Com isso, torna-se relevante analisar os resultados do transplante (Tx) neste grupo, de acordo com o tipo de doador. Métodos: Estudo retrospectivo que avaliou ao final de 12 meses resultados de pacientes igual ou acima de 60 anos submetidos a Tx, entre 11/2008 a 06/2013. Resultados: Foram feitos 307 Tx, 26 em pacientes idosos, sendo 17 de doador falecido (DF) e 9 doador vivo (DV). A idade média em anos do receptor foi de $62,6 \pm 2,2$ no grupo $D V$ e $64,2 \pm 5,2$ no grupo $D F(p=0,24)$. A idade média em anos do doador foi $38,9 \pm 10,0$ no grupo DV e $42,9 \pm 9,4$ no grupo DF ( $p=0,25)$. O grupo DF possuía um maior número de pacientes em hemodiálise $(94,1 \%$ vs $66,7 \%, p=0,03)$. Nenhum paciente no grupo DV apresentou função retardada do enxerto enquanto $43,8 \%$ apresentaram no grupo DF $(p=0,03)$. O tempo de isquemia fria no grupo DF foi em média $17,6 \pm 7,3$ horas. Rejeição aguda ocorreu em $18,8 \%$ no grupo DF e $12,5 \%$ no DV $(p=1,0)$. A sobrevida do paciente e enxerto em 12 meses foram iguais nos grupos, 93,8\% no grupo DF e $77,8 \%$ no grupo DV ( $p=0,53$ ). A causa dos dois óbitos no grupo DV e do único óbito no grupo DF foi infecciosa, e nenhum deles recebeu alta hospitalar após o Tx. O grupo DV apresentou melhor função renal $(\mathrm{ClCr}=60,6 \mathrm{ml} / \mathrm{min}$ vs $\mathrm{ClCr}=46,9 \mathrm{ml} / \mathrm{min}$, $p=0,02)$ ao final de 12 meses. Os pacientes do grupo DF apresentaram maior taxa de internação $(68,8 \%$ vs $57,1 \%, p=0,6)$ troca de IMS $(56,3 \%$ vs $33,3 \%, p=0,4)$, infecção por citomegalovírus ( $18,1 \%$ vs $11,1 \%, p=1)$, infecção urinária $(50 \%$ vs $22,2 \%, p=0,3)$ e diabetes pós-transplante $(6,3 \%$ vs $0 \%, p=1,0)$. Conclusão: Transplante renal em pacientes idosos deve ser encorajado, seja com doador vivo ou falecido, mesmo que este último apresente um maior número de complicações.

\section{ORAL 091 Análise do efeito da indução com timoglobulina nas subpopulações linfocitárias T e B em idosos transplantados renais em protocolo de conversão precoce para everolimo}

\begin{abstract}
ÁREA: RIM
INSTITUIÇÃO:

Universidade de

São Paulo - USP
\end{abstract}

\author{
AUTORES: \\ Freitas, GRR \\ Fernandes, ML \\ Agena, $F$ \\ Triboni, AHK \\ Ramos, $F$ \\ Lemos, FBC \\ Nahas, WC \\ David-Neto, E \\ Coelho, $\mathrm{V}$ \\ Galante, NZ
}

Não há estudos sobre efeito diferencial da timoglobulina (ATG) em subpopulações linfocitárias de Idosos (Ids) receptores de transplante renal (TxR), motivando este estudo. Estudamos o efeito de indução com baixa dose de ATG nas contagens de linfócitos T e $B$ naive, memória e reguladores (reg) em $I d s(n=8 ; 62 \pm 3 a)$ e não idosos (nlds)(n=8;33 $\pm 7 a)$ receptores de TxR em protocolo de conversão precoce para everolimo (EVL) Coletamos amostras de sangue no pré-TxR, 1 mês pós-TxR e 1 mês após conversão. Todos receberam dose única de ATG $(2 \mathrm{mg} / \mathrm{Kg})$, tacrolimo, prednisona e micofenolato, este suspenso após introdução de EVL. Contagem de linfócitos totais(LT) pré-TxR era menor em Ids que nlds(1225;700-1700vs2490;1400-3200 cels/mm3;p<005) e LT reduziram com 1 Mês nos Ids (700;380-1500 cels/mm3,p<005), mas não nos nlds (2805;710-3250 cels/mm3,p=NS), permanecendo reduzida nos Ids com 1 mês após conversão(885;370-1030 cels/mm3). Somente Ids apresentaram redução absoluta das Tregs CD4+CD25+CD127-FoxP3+(17,62;6,58-31,85vs7,81;2,63-19,25vs9,66;3,68-22,59 cels/mm3), no entanto, ambos, Ids e nlds apresentaram redução percentual dos Treg CD39+(CD4+CD25+CD127-CD39+FoxP3+) Ids e nlds apresentaram redução percentual de Breg(CD19+CD24hiCD38hi); Ids:(108; 16-20)vs(757; 226-115) vs(4; 127-88)\% cels, e nlds(742; 411-14)vs(446; 255-648)\% cels,p<005). Os nlds apresentaram elevação absoluta e percentual de linfócitos $B$ naive e $T$ CD8+ 1 mês pós-TxR A razão Breg/ Bmemória(CD19+CD24intCD38-) se reduziu em ambos, Ids(078; 004-202)vs(037; 005128) vs $(020 ; 003-077) p<005)$ e nlds $(039 ; 015-15) v s(019 ; 007-04 ; p<005)$. ATG dose baixa reduziu de maneira sustentada os $\mathrm{LT}$, Treg e Breg nos Ids, sem reestabelecimento após conversão. O efeito do ATG é mais pronunciado nos Ids comparado aos nlds. 


\section{Monitorização dos anticorpos Anti-HLA durante o primeiro ano do transplante renal: correlação com episódios de rejeição aguda}

ÁREA: RIM

\section{INSTITUIÇÃO:}

Hospital Geral de

Bonsucesso -

Rio de Janeiro- RJ,

Laboratório de

Histocompatibilidade

e Criopreservacao da

UERJ - Rio de Janeiro - RJ

\section{AUTORES:}

Glasberg, Denise Segenreich

Monteiro de Carvalho, Deise DB

Matuck, Tereza

Holanda, Maria Izabel N

Borela, Alvaro

Christiani, Luiz Fernando

Porto, Luis Cristovao

\begin{abstract}
Introdução: A associação entre a presença de DSA, em pcts com prova cruzada negativa, e a ocorrência de rejeição mediada por anticorpos (RMA) e menor sobrevida do enxerto já foi demonstrada. Estimar a relevância clínica desses acs, em um receptor, é um grande desafio e portanto novas estratégias de monitorização imunológica são necessárias. Objetivo: Monitorar a presença de DSA, bem como a variação dos seus títulos durante o primeiro ano do transplante, e correlacionar com rejeição aguda e função do enxerto ao final deste. Método: Foram analisados 389 soros de 71 pcts incluídos. A pesquisa de DSA foi realizada por SAFB nas amostras: pré-tx, 14, 30, 90, 180 e 365 d após o transplante. Os pcts foram separados em 3 grupos de diferentes riscos imunológicos (pré-tx): A) DSA-, B)DSA+ com MFI >1000e<5000 e C) DSA+ com MFI>5000. Resultados: 15 pcts apresentaram DSA pré-tx. RMA foi mais frequente no grupo $C(p=0,02)$. De acordo com a variação dos títulos de DSA pós-tx os pcts foram novamente agrupados: I) permaneceu DSA- $(n=50)$, II) diminuiu ou manteve títulos $(n=13)$ e III) aumentou títulos $(n=8), 6$ DSA de novo 3 pcts do grupo I e um pct do grupo II apresentaram rejeição aguda celular. Não se observou oscilação significativa nos títulos de acs durante esses eventos. Nenhum pct desses grupos apresentou RMA. RMA ocorreu em 2 pcts do grupo III, ambos com aumento do DSA MFI. Não foi observada diferença significativa na TFG entre os grupos. Entretanto, observou-se uma diferença na TFG entre os pcts que apresentaram ou não rejeição aguda, sendo menor nos primeiros $(p=0,04)$. Conclusão: A monitorização prospectiva dos acs pode ajudar a identificar pcts em maior risco de RMA, e o aumento do MFI deve ser interpretado como um sinal de alerta, sobretudo em pcts previamente sensibilizados.
\end{abstract}

\section{ORAL 116 Avaliação de perfil imunológico de pacientes sensibilizados transplantados renais com longo tempo de função de enxerto por análise descritiva de subpopulações linfocitárias B e T periféricas}

ÁREA: RIM

INSTITUIÇÃO:

Universidade de

São Paulo - USP

\section{AUTORES: \\ Galante, NZ \\ Fernandes, ML \\ Agena, $F$ \\ Triboni, AHK \\ Freitas, GRR \\ Aguirre, AR \\ Nahas, WC \\ Coelho, $\mathrm{V}$ \\ David-Neto, E}

Descrevemos neste estudo as subpopulações de linfócitos (Linf) T e B de pacientes sensibilizados (PSens) receptores de transplante renal (TxR) com função estável do enxerto. Quantificamos a composição basal das subpopulações de linfócitos $T$ e B em PSens receptores de TxR com função do enxerto estável (TFG $>29 \mathrm{~mL} / \mathrm{min}$ ) recrutados para estudo clínico prospectivo de conversão tardia de imunossupressão (IS) padrão com tacrolimo(TAC)/ micofenolato(MPS)/ prednisona(PRED) para IS quádrupla com TAC/MPS/PRED/ sirolimo. Utilizando citometria de fluxo realizamos a contagem absoluta e percentual das seguintes subpopulações de Linf: CD4+ naïve (CD3+CD4+CD45RA+CCR7+), T CD4+ memória central (MC) (CD3+CD4+CD45RACCR7+), T CD4+ memória efetora (ME) (CD3+CD4+CD45RA-CCR7-), T CD8+ memória efetora RA+ (TEMRA) (CD3+CD4+CD45RA+CCR7-), T reguladora (reg) (CD3+CD4+CD25+CD127loFOXP3+), B naïve (CD19+CD24loCD38lo) B memória (Bmem)(CD19+CD24loCD38-) e Bregs (CD19+CD24hiCD38hi). Todos pacientes $(n=10)$ eram mulheres, idade $435 \pm 105$ anos, maioria caucasiana $(n=8)$, receptora de primeiro TxR $(n=9)$ de doador falecido $(n=6)$, apresentando $4 \pm 16$ anos do TxR. Vários apresentavam PRA elevado (20-70\%) $(n=7)$, gestações $(n=10)$ e transfusões sanguíneas $(n=6)$ prévias à época do TxR. Encontramos valores percentuais dos linfócitos T CD4+ naïve, MC, ME de 66, 36 e 649\% das células CD3+CD4+, dos T CD8+ TEMRA de 682\% das células CD3+CD8+, dos Tregs de 26,4\% das células CD3+CD4+CD25+, das B naïve, Bmem e Bregs de 88, 235 e $88 \%$ das células CD19+. O número absoluto das mesmas subpopulações de Linf foram respectivamente 31, 15, 234, 93, 7, 26, 23 e 5 cels/mm3. Os PSens receptores de TxR com longo tempo de função de enxerto estável apresentam predomínio do fenótipo memória nas subpopulações de linfócitos T e B. 


\section{ORAL 117 Transplante renal com doador abo incompatível? Experiência de um programa organizado no Brasil}

\author{
ÁREA: RIM \\ INSTITUIÇÃO: \\ Núcleo de Transplantes - \\ Hospital Samaritano de \\ São Paulo
}

\section{AUTORES: \\ Castro MCR \\ Malafronte $P$ \\ Silva EF \\ Cunha MFM \\ Baptista-Silva JC \\ Luzzi JR \\ Camargo MFC}

$25 \%$ dos doadores vivos analisados para transplante (tx) renal são incompatíveis no sistema ABO. Entre 2012-14, através do PROADI-SUS (MS), 25 renais crônicos foram avaliados para tx com doador $A B O$ incompatível após consentimento informado. O tempo em diálise foi de 72 meses $+/-16,20$ pacientes $(80 \%)$ apresentavam sensibilização antiHLA, 12 com $P R A>50 \% .12$ pacientes foram excluídos e 4 ainda estão em avaliação para tx. 9 foram transplantados, 3 com doador falecido ABO compatível antes do preparo, e 6 com doadores $\mathrm{ABO}$ incompatíveis após preparo. Dos 6 pacientes transplantados com doadores $A B O$ incompatíveis tinham as seguintes características: 5 eram mulheres, 4 eram retransplantes, 2 priorizados por falta de acesso vascular. A idade variou de 29 a 61 anos, 5 eram do tipo sanguíneo $O$ e um $B$ ( 5 doadores tipo $A, 1$ do tipo $B$, todos parentes) e 2 tinham anticorpo anti-HLA contra o doador em títulos baixos. O título de isoaglutininas antes do preparo variou de $1 / 32$ a 1/256. Os pacientes foram tratados com Rituximab e $42+/-23$ sessões de plasmaferese (PF), para reduzir títulos de isoaglutininas para $<1 / 16$. Os tx foram realizados com Timoglobulina, Tacrolimo, Micofenolato e Prednisona. 3 pacientes elevaram os títulos de isoaglutininas no pós-tx (1 deles com rejeição à biópsia) e receberam respectivamente de 1, 2 e 14 sessões de PF. 3 bx foram realizadas entre 7-14 dias pós-tx e revelaram: NTA (2) e 1 rejeição Banff IB, todas C4d positivo. O tempo de seguimento varia de 3-26 meses, não ocorreram óbitos nem perdas de enxerto, a creatinina é de $14+/-09 \mathrm{mg} / \mathrm{dl}$ e as últimas dosagens de isoaglutininas variam de $1 / 2$ a $1 / 32$. Concluímos que o tx renal com doador $A B O$ incompatível é seguro em nosso meio, com bons resultados. A análise de custo, em parceria com a Fundação Getúlio Vargas está em curso.

ORAL 118

\section{Hipercalcemia após o transplante renal: um fator de risco para disfunção do enxerto ainda negligenciado?}

\section{ÁREA: RIM}

\section{INSTITUIÇÃO:}

Hospital das Clínicas

da Faculdade de

Medicina da USP

\section{AUTORES: \\ Araujo, MJCLN \\ Custodio, MR \\ Ramalho, JAM \\ Moyses, $\mathrm{R}$ \\ Nahas, W \\ David-Neto, E}

Objetivos: Avaliar prevalência de HiCa após Tx renal e identificar fatores associados. Material e Método: Análise retrospectiva de prontuário dos Tx renais ocorridos entre 2007 e 2013 no serviço do HC-FMUSP. Dados do pré, 1 e 4 anos após o Tx foram avaliados. $\mathrm{HiCa}$ foi definida como cálcio iônico (Cai) $>5,3 \mathrm{mg} / \mathrm{dl}$. As análises foram realizadas naqueles com filtração glomerular estimada (MDRD)> $30 \mathrm{ml} / \mathrm{min} 1$ ano após o Tx para evitar a influência da disfunção renal no metabolismo ósseo. Resultados: Ocorreram $1167 \mathrm{Tx}$ renais. Analisamos os dados de 729 pacientes com MDRD $>30 \mathrm{ml} / \mathrm{min}$ e dados de Cai após 1 ano de Tx. HiCa foi diagnosticada em 31\% da amostra. Pacientes com HiCa já apresentavam no pré Tx níveis de Cai, FA, P, Mg e PTH mais elevados. Não houve diferença entre os grupos em relação à idade no Tx, sexo e diabetes, mas o grupo HiCa tinha maior tempo em diálise. Após 1 ano, além da $\mathrm{HiCa}$, tinham níveis mais elevados de FA, PTH e mais baixos de P e MDRD (52,8 vs 56,7 ml/min). Após 4 anos, pacientes com HiCa, ainda apresentavam Cai e PTH mais altos, e MDRD mais baixo do que o grupo com Cai adequado. Discussão e Conclusões: Mesmo em amostra com função do enxerto adequada, encontramos alta prevalência de HiCa 1 ano após o Tx. Pior controle do HPT no pré-tx parece ter sido o principal fator contribuinte. Além disto, a associação de $\mathrm{HiCa}$ com menor MDRD sugere que ela possa influenciar negativamente a função do enxerto a longo prazo. 


\section{[:HIC,Alill 20017}

A M ERICAN $T r \bar{a} n s p l a n t$ C O N G R S S April 29 - May 3, 2017 * McCormick Place * Chicago, IL

Disponível em: https://onlinelibrary.wiley.com/toc/16006143/2017/17/S3 
CITATION INFORMATION: Montanari E, Pimenta J, Schuurman H.-J, Meier J, Meyer R, Balaphas A, Sidibé J, Thomas A, Passemard S, Gerber-Lemaire S, Gonelle-Gispert C, Buhler L. Beneficial Effects of Human Mesenchymal Stromal Cells on Porcine Hepatocytes Viability and Albumin Secretion Am J Transplant. 2017;17 (suppl 3).

\section{Abstract\# D17 \\ Senescence and Uremia Effects in Circulating T Cells Diverge in TREG Population and Cause T Cell Shift to a Memory Profile. G. Freitas, ${ }^{1}$ M. Fernandes, ${ }^{1}$ F. Agena, ${ }^{1}$ O. Jabuul,,${ }^{2}$ V. Coelho, ${ }^{3}$ F. Lemos, ${ }^{1}$ F. Ramos, ${ }^{1}$ A. Triboni, ${ }^{1}$ E. David-Neto, ${ }^{1}$ N. Galante. ${ }^{1 ~}{ }^{2}$ Renal Transplantation Service, University of Sao Paulo, Sao Paulo, Brazil; ${ }^{2}$ Department of Geriatrics, University of Sao Paulo, Sao Paulo, Brazil, ${ }^{3}$ Laboratory of Immunology, InCor, University of Sao Paulo, Sao Paulo, Brazil.}

Elderly kidney transplant recipients(EKtx) have higher malignancies and infections rates, but lower acute rejection incidence. Senescence seems to result in shift to memory profile and uremia in premature immunological aging. Understanding combined senescence and uremia effects in immune system can improve EKtx immunosuppression individualization.

We analyzed senescence and uremia effects in circulating lymphocyte subpopulations, comparing healthy young $(\mathrm{HY})(\mathrm{n}=14,26 \pm 2 \mathrm{y})$, healthy elderly $(\mathrm{n}=15,79 \pm 7 \mathrm{y})$, young kidney transplant recipients $(\mathrm{n}=17,36 \pm 7 \mathrm{y})$ and $\operatorname{EKtx}(\mathrm{n}=27,65 \pm 3 \mathrm{y})$ before transplant. We analyzed the following phenotypes: TEMRA $\left(\mathrm{CD} 4^{+} \mathrm{CCR} 7^{-} \mathrm{CD} 45 \mathrm{RA}^{+}\right)$, naive $\left(\mathrm{CD} 4{ }^{+} \mathrm{CCR} 7^{+} \mathrm{CD} 45 \mathrm{RA}^{+}\right)$, central memory $(\mathrm{TCM})\left(\mathrm{CD} 4^{+} \mathrm{CCR} 7^{+} \mathrm{CD} 45 \mathrm{RA}^{-}\right)$ and effector memory (TEM) $\left(\mathrm{CD}^{+} \mathrm{CCR} 7^{-} \mathrm{CD}^{2} 5 \mathrm{RA}^{-}\right) \mathrm{T}$ cells, regulatory $\mathrm{T}$ cells (TREG) $\left(\mathrm{CD} 4{ }^{+} \mathrm{CD} 25^{+} \mathrm{CD} 127-\mathrm{FOXP}^{+} \mathrm{CD} 39^{+}\right)$, naïve $\left(\mathrm{CD} 19^{+} \mathrm{CD} 24^{\text {int }} \mathrm{CD} 38^{\text {int }}\right)$, memory $\left(\mathrm{CD} 19^{+} \mathrm{CD} 24^{\mathrm{hi}} \mathrm{CD} 38^{\mathrm{lo}}\right)$ and regulatory(BREG)(CD19+ $\left.\mathrm{CD} 24^{\mathrm{Hi}} \mathrm{CD} 38^{\mathrm{Hi}}\right) \mathrm{B}$ cells. Percentages and absolute lymphocyte counts were compared by Mann Whitney and Two-Way ANOVA.

Senescence and uremia correlated with lower absolute counts for B and T lymphocytes, affecting many subpopulations with memory, naïve and regulatory profiles. Senescence and uremia resulted in higher percentage of memory subsets, the former in TCM $\left[\mathrm{F}(1,72)=6.2, \mathrm{p}=0.02, \eta^{2}=0.08\right]$ and the latter in $\operatorname{TEM}[\mathrm{F}(1,72)=4.7$, $\left.\mathrm{p}=0.03, \eta^{2}=0.06\right]$. We found opposing effects on Treg: higher percentage in senescence $\left[F(1,72)=4.4, p=0.04, \eta^{2}=0.06\right]$ and lower in uremia $[F(1,72)=5.7, p=0.02$, $\left.\eta^{2}=0.07\right]$. Senescence and uremia presented additive effects on absolute cell counts, lowering total $\mathrm{T}$ and $\mathrm{B}$ cell subpopulations, but without interaction. Combined effect of senescence and uremia also resulted in higher BREG percentage [EKtx-10(7-14)\% of CD19 vs. HY-6(5-8) $\%$ of CD $19, \mathrm{p}=0.02]$.

Senescence and uremia are responsible for global decrease of absolute lymphocyte counts and percentage shift to T memory profile, but opposing effects on TREG percentage. Combination of senescence and uremia induces cumulative effects on lymphocyte counts, but do not interact. These encourage tailoring EKTx immunosuppression, favoring a selective control of memory $\mathrm{T}$ cells whith preservation of TREGs and BREGs.

CITATION INFORMATION: Freitas G, Fernandes M, Agena F, Jabuul O, Coelho V, Lemos F, Ramos F, Triboni A, David-Neto E, Galante N. Senescence and Uremia Effects in Circulating T Cells Diverge in TREG Population and Cause T Cell Shift to a Memory Profile Am J Transplant. 2017;17 (suppl 3).

\footnotetext{
Abstract\# D18

Technically Successful Miniaturization of Blood Hemofilters for an Artificial Kidney via Bioengineering Techniques. R. Forbes, ${ }^{1} \mathrm{C}$. Kensinger, ${ }^{1}$ S. Karp, ${ }^{1}$ J. Groszek, ${ }^{1}$ A. Buck, ${ }^{2}$ D. Colvin, ${ }^{2}$ S. Roy, ${ }^{3}$ W. Fissell. ${ }^{1}$ Vanderbilt University Medical Center, Nashville; ${ }^{2}$ Institute of Imagine Science, Vanderbilt University, Nashville; ${ }^{3}$ University of California San Francisco, San Francisco.

Background: Creating flow channel pathways for an implantable artificial kidney with minimal risk of thrombosis is particularly difficult when miniaturizing into a multilayer bio-hybrid device. Computational modeling and in vitro imaging facilitated rapid iterative development of a low-thrombosis blood conduit with sequentially narrower flow channels.

Methods: Following preclinical implantation trials of hemofilter cartridges, correlations between low shear rates in silico and areas of clot nucleation in vivo led to modification of flow path geometry. Computational fluid dynamics simulations were validated by flow field imaging in vitro. Designs that eliminated recirculation and stasis were machined from medical grade polycarbonate and implanted into six Class A dogs for 30 days. We implanted two cartridges for each of the following
} flow channel pathway sizes: $500 \mu \mathrm{m}, 750 \mu \mathrm{m}$, and $1000 \mu \mathrm{m}$.

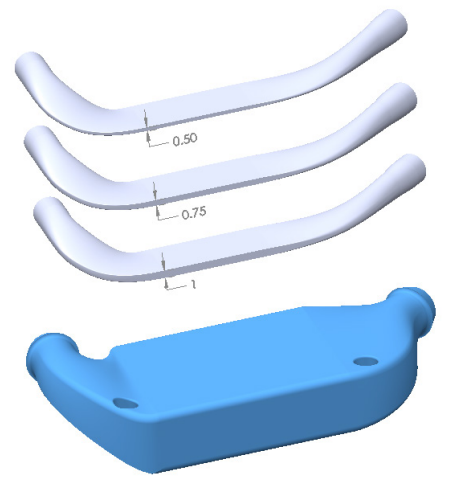

Serial Doppler ultrasound examination verified patency of blood conduits. All dogs were maintained on acetylsalicylic acid. At postoperative day 30 , the devices were harvested and examined for evidence of thrombosis.

Results: Optimized designs had a smaller cross sectional area, helical inflow and a larger angle outflow tract. No surgical complications were identified. No hemolysis or distal embolization was noted. The optically transparent cartridges had no visible thrombosis at any flow channel pathway size

Explants of Blood Flow Conduits at 500 um, 750 um , and 1000 um
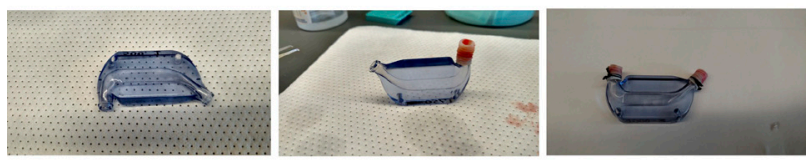

a) 500 um Device post Explant

b) 750 um Device post Explant

C) 1000 um Device post Explant

Conclusions: Meticulous attention to the flow fields in a blood contacting device can reduce thrombosis and eliminate the need for systemic anticoagulation, even as miniaturization of the device with narrower flow channels is undertaken.

CITATION INFORMATION: Forbes R, Kensinger C, Karp S, Groszek J, Buck A, Colvin D, Roy S, Fissell W. Technically Successful Miniaturization of Blood Hemofilters for an Artificial Kidney via Bioengineering Techniques Am J Transplant. 2017;17 (suppl 3).

DISCLOSURES: Roy, S.: Ownership interest, Silicon Kidney, LLC. Fissell, W.: Ownership interest, Silicon Kidney, LLC.

\section{Abstract\# D19}

Biodistribution of Adipose Derived Regenerative Cells Administered via the Renal Artery in Novel Rat Transplant Model. R. Ghita, ${ }^{1,2}$ R. Lathan, ${ }^{2}$ D. Hillyard, ${ }^{2}$ P. Mark,,${ }^{1,2}$ M. Clancy. ${ }^{1,2}{ }^{l}$ Glasgow Renal and Transplant Unit, Queen Elizabeth University Hospital Glasgow, Glasgow, United Kingdom; ${ }^{2}$ Institute of Cardiovascular and Medical Sciences, University of Glasgow, Glasgow, United Kingdom.

Introduction:

A novel rodent model of ischaemia- reperfusion injury (IRI) has shown significant improvement in renal function and histology after administration of adipose derived regenerative cells (ADRCs). However the exact mechanism on how these regenerative cells ameliorate IRI is not fully understood. Our research aims to identify the biodistribution - spacial and temporal post therapeutic administration of ADRCs. Methods:

ADRCs were extracted from the inguinal fat of the Fisher 344 rat, labelled with a near infrared lipophilic dye, DiR, and injected via the renal artery of our surgical IRI rat model. Whole body imaging was performed using the IVIS spectrum imaging system. Organs (kidneys, heart, lung, brain, spleen, liver) were then removed and imaged at various time points and also imaged post ClearT2 tissue clearance. Results:

Alone, DiR labelled cells strongly fluoresced. Whole body scanning of the rat post $\mathrm{ADRC}$ injection at various timepoints demonstrated no signal from DiR-labelled ADRCs. However, high ADRC cell numbers $\left(>2 \times 10^{\wedge} 5\right)$ were detected in various ex vivo organs at early time points. Low cell numbers $\left(<2 \times 10^{\wedge} 5\right)$ were undetectable. Clearing the ex vivo organs with ClearT2 did not improve visibility in select tissues. Discussion:

Histology and cytometry will be performed to refine localization of injected ADRCs. Data will support our experiments that investigate microenviromental effects of ADRCs.

CITATION INFORMATION: Ghita R, Lathan R, Hillyard D, Mark P, Clancy M. Biodistribution of Adipose Derived Regenerative Cells Administered via the Renal Artery in Novel Rat Transplant Model Am J Transplant. 2017;17 (suppl 3). 


\section{Abstract\# D102}

Overweight Kidney Transplant Recipients Are at Risk of Being Overdosed Following Standard Bodyweight-Based Tacrolimus Dosing. D. Hesselink, ${ }^{1}$ L. Andrews, ${ }^{2}$ B. de Winter, ${ }^{2}$ J. Tang, ${ }^{3}$ N. Shuker,${ }^{2}$ R. Bouamar, ${ }^{2}$ R. van Schaik, ${ }^{4}$ B. Koch, ${ }^{2}$ T. Van Gelder. ${ }^{1}$ Internal Medicine, Erasmus MC, Rotterdam, Netherlands, ${ }^{2}$ Hospital Pharmacy, Erasmus MC, Rotterdam, Netherlands; ${ }^{3}$ Laboratory Medicine, West China Hospital of Sichuan University, Chengdu, China; ${ }^{4}$ Clinical Chemistry, Erasmus MC, Rotterdam, Netherlands.

Bodyweight-based dosing of tacrolimus (Tac) is considered standard care, even though the available evidence is thin. An increasing proportion of transplant recipients is overweight, prompting the question if the starting dose should always be based on bodyweight.

The aim of this study was to investigate whether a Tac starting dose based on bodyweight leads to the achievement of Tac target whole-blood predose concentrations $\left(\mathrm{C}_{0}\right)$ in overweight patients on day 3 after transplantation. This was defined as the first steady state concentration attained after five unaltered Tac doses. This is a post-hoc analysis of a randomized-controlled trial investigating whether adaptation of the Tac starting dose according to CYP $3 A 5$ genotype increases the proportion of kidney transplant recipients reaching the target Tac predose concentration. In this trial, patients were randomized to receive Tac in either the standard, bodyweight-based dose of $0.20 \mathrm{mg} / \mathrm{kg} / \mathrm{day}$ according to the package insert, or to a dose based on their CYP $3 A 5$ genotype. For the analysis, the data were divided into three groups: the standard-dose group, the genotype-based group, and all patients scaled to the standard bodyweight dose. The correlation between Tac $\mathrm{C}_{0}$ and bodyweight (or BMI) was investigated by calculating the goodness of fit. Dosing guidelines were calculated using linear regression lines.

Data was available for 203 kidney transplant recipients with a median BMI of 25.6 (range 17.2-42.2) and bodyweight of $78.9 \mathrm{~kg}$ (range 37.6-123.1). More than 50\% of the overweight or obese patients had a tacrolimus predose concentration above the target range of $10-15 \mathrm{ng} / \mathrm{mL}$. The CYP3A5 non-expressers tended to be above target when they weighed more than $67.5 \mathrm{~kg}$ or had a BMI of 24.5 or higher. If the BMI is $25-30$, only $85 \%$ of the standard dose $(0.2 \mathrm{mg} / \mathrm{kg} / \mathrm{day})$ should be prescribed to reach the target concentration, and if the BMI is $30-35$ we propose $75 \%$ of the standard dose. The dosing guideline for patients with an unknown genotype was validated using the FDCC dataset.

This study demonstrates that dosing tacrolimus solely on bodyweight results in overexposure in more than half of overweight or obese patients.

CITATION INFORMATION: Hesselink D, Andrews L, de Winter B, Tang J, Shuker N, Bouamar R, van Schaik R, Koch B, Van Gelder T. Overweight Kidney Transplant Recipients Are at Risk of Being Overdosed Following Standard Bodyweight-Based Tacrolimus Dosing Am J Transplant. 2017;17 (suppl 3).

DISCLOSURES: Hesselink, D.: Other, Astellas Pharma BV, Lecture fee, consulting fee and grant support, Bristol-Myers Squibb, Lecture fee, consulting fee and grant support, Chiesi Pharmaceuticals, Lecture fee, consulting fee and grant support, MSD Pharmaceuticals, Lecture fee, consulting fee and grant support, Novartis Pharma B.V. Lecture fee, consulting fee and grant support, Roche Pharma, Lecture fee, consulting fee and grant support. Van Gelder, T.: Consulting fee, Sandoz Pharma, Novartis Pharma BV, Roche Pharma, Teva Pharma, Other, Chiesie Pharmaceuticals, Lecture fee, Astellas Pharma BV, Consulting and lecture fees.

\section{Abstract\# D103}

Single-Center, Prospective, Open Label Pilot Study to Investigate the Effectiveness of Everolimus Associated with Mycophenolic Acid and Prednisone in Adult Patients Submitted to an Allograft Renal Transplant with Calcineurin Inhibitor Withdrawl on Week 16th. L. Giordano, ${ }^{1,2}$ M. Lasmar, ${ }^{1,2}$ H. Vianna, ${ }^{1,2}$ E. Lasmar. ${ }^{1,2}{ }^{2}$ Renal Transplant Unit, Hospital Universitário Ciências Médicas de Minas Gerais, Belo Horizonte, Minas Gerais, Brazil; ${ }^{2}$ Nephrology Department, Rede Mater Dei de Saúde, Belo Horizonte, Minas Gerais, Brazil.

Although CI have proven efficacy in kidney transplantation worldwide, they are drugs with nephrotoxic potential and may contribute to chronic renal allograft nephropathy. As a result, there is an interest in developing regimens that involve CI withdrawal or minimization.

This study acessed whether everolimus, introduced on the 16th post-transplant week in place of tacrolimus and combined with mycophenolate acid and prednisone reduced the incidence of chronic allograft nephropathy and presented similar renal function at one year measured by creatinine levels compared to a control group mantained on tacrolimus + mycophenolate acid + prednisone.

The study population was composed of 28 kidney transplant patients considered of low immunological risk and defined as follows: recipients of a first kidney transplant (living or deceased donor), with PRA $<10 \%$ and no pre-transplant DSA. Additionally, the patients had to present stable creatinine levels and absence of immunological events during the first three months post-renal transplant.

In this study, 15 patients were randomized to the tacrolimus arm and 13 to recieve everolimus. At the end of 12 months of transplantation, a protocol allograft biopsy was performed.
At one year, creatinine levels were similar in both groups $(1.19 \mathrm{mg} / \mathrm{dL}$ in the everolimus arm vs. $1.44 \mathrm{mg} / \mathrm{dL}$ in the tacrolimus arm; $\mathrm{p}=0.133$ ).

The graft rejection rate in either arm was exactly the same: $7.1 \%(\mathrm{p}=0.644)$. Regarding graft loss, we did not observe any loss in the everolimus group. In the tacrolimus group, two patients $(7.1 \%)$ lost the kidney graft, a difference that was not statistically significant $(p=0.78)$. There were no deaths in either group during the study.

Three patients in the tacrolimus arm had considerable interstitial fibrosis and tubular atrophy $(20-40 \%)$ in biopsy samples. In the everolimus arm, only one patient presented similar findings. In the tacrolimus arm, biopsy disclosed in one patient signs of calcineurin toxicity $(9.1 \%)$.

In low immunological risk patients with initial triple immunosuppression, replacing tacrolimus for everolimus on the 16th week resulted in a similar kidney function and rejection rates in a one year follow-up.

CITATION INFORMATION: Giordano L, Lasmar M, Vianna H, Lasmar E. Single-Center, Prospective, Open Label Pilot Study to Investigate the Effectiveness of Everolimus Associated with Mycophenolic Acid and Prednisone in Adult Patients Submitted to an Allograft Renal Transplant with Calcineurin Inhibitor Withdrawl on Week 16th Am J Transplant. 2017;17 (suppl 3).

DISCLOSURES: Giordano, L.: Grant/Research Support, Novartis, Scientific Medical Investigator. Lasmar, M.: Grant/Research Support, Novartis, Scientific Medical Investigator. Vianna, H.: Grant/Research Support, Novartis, Scientific Medical Investigator. Lasmar, E.: Grant/Research Support, Novartis, Scientific Medical Investigator.

\section{Abstract\# D104}

A Critical Analysis of Equations for MPA Exposure in Patients Under EC-MPS and Tacrolimus. E. David-Neto, A. Triboni, F. Ramos, F. Agena, P. Romano, G. Freitas. Hospital das Clinicas FMUSP, Sao Paulo, Brazil. Mycophenolic acid(MPA) PK, from enteric-coated mycophenolate sodium(EC-MPS) has a broad range of Tmax avoiding the use a single concentration to calculate the area-under-the-time-concentration curve(AUC). Either for research or for clinical MPA monitoring, a complete AUC is troublesome for the patients(pts). We have developed abbreviated equations in 59 adult( $54 \pm 16 \mathrm{y})$ pts (29males,43whites) with 171 complete MPA-AUC ${ }_{0-12 h}$, under TAC/EC-MPS using 59 curves measured at mean of $31 \pm 4$ days after transplant, to develop the equations, and the remaining 112 performed at a mean of $109 \pm 59 \mathrm{~d}$ for validation. We also compared our results with 5 other equations(4 with EMIT) available in the literature, comparing estimated AUC(eAUC) with measured AUC(mAUC), bias and 10\%/30\% accuracy. MPA was measured by UPLC MS-MS. EMIT data was transformed using Emit $=1.012$ HPLC +0.244 . The eAUCs that measure MPA up to 6hours, had an acceptable low bias with more results in the $10-30 \%$ range than those up to $4 \mathrm{~h}$. A highly adequate eAUC is obtained with $8 \mathrm{~h}$ of blood collection. This analysis offers blood sampling alternatives depending on the precision needed.

\begin{tabular}{|c|c|c|c|c|c|c|}
\hline & Equations & eAUC & p & Bias & $30 \%$ & $10 \%$ \\
\hline Emit (MPA) & $\begin{array}{l}\mathrm{mAUC}=56 \pm 36 \mu \mathrm{g}^{\star} \mathrm{hr} / \\
\mathrm{mL}\end{array}$ & & & & & \\
\hline $\begin{array}{l}\text { Sanchez Ther } \\
\text { Drug Monit, } \\
2012\end{array}$ & $\begin{array}{l}11.15+0.68 \times \mathrm{x} 1+0.45 \mathrm{xC} \\
1.5+0.57 \mathrm{xC} 2+8.16 \mathrm{xC} 4\end{array}$ & $57 \pm 35$ & NS & $+1 \pm 19$ & 74 & 29 \\
\hline $\begin{array}{l}\text { Yao Ther } \\
\text { Drug Monit, } \\
2015\end{array}$ & $\begin{array}{l}10.44+0.7 \times C 1+1.22 \times C 2 \\
+1.75 \times C 4+4.36 \times C 6\end{array}$ & $55 \pm 29$ & 0.026 & $-2.5 \pm 14$ & 79 & 40 \\
\hline $\begin{array}{l}\text { Sommerer } \\
\text { Br J Clin } \\
\text { Pharmacol, } \\
2010 \\
\end{array}$ & $\begin{array}{l}11.5+0.99 \times \mathrm{xC} 0+1.56 \mathrm{xC} \\
1+0.74 \times \mathrm{C} 2+0.87 \mathrm{xC} 3+ \\
2.09 \mathrm{xC} 4\end{array}$ & $49 \pm 25$ & 0.000 & $-7 \pm 16$ & 78 & 29 \\
\hline $\begin{array}{l}\text { Huang } \\
\text { Int J Clin } \\
\text { Pharmacol } \\
\text { Ther, 2016 } \\
\end{array}$ & $\begin{array}{l}22.13+1.7 \times C 0.5+0.61 \times C \\
1.5+0.78 \times C 2+1.83 \times C 4\end{array}$ & $52 \pm 21$ & 0.025 & $-3 \pm 19$ & 67 & 23 \\
\hline $\begin{array}{l}\text { (UPLC MS- } \\
\text { MS) (MPA) }\end{array}$ & $\begin{array}{l}\mathrm{mAUC}=53 \pm 34 \mu \mathrm{g} * \mathrm{hr} / \\
\mathrm{mL}\end{array}$ & eAUC & p & Bias & $30 \%$ & $10 \%$ \\
\hline $\begin{array}{l}\text { HC- } \\
\text { FMUSP } \\
\text { gh }\end{array}$ & $\begin{array}{l}0,081+0,661 \times \mathrm{xC} 0+0,564 \\
\mathrm{xC} 1.5+0,768 \mathrm{xC} 2+1,60 \\
0 \mathrm{xC} 3+1,560 \times \mathrm{xC} 4+2,421 \\
\mathrm{xC} 6+3,590 \times \mathrm{xC} 8 \\
\end{array}$ & $53 \pm 34$ & NS & $0 \pm 14$ & 96 & 56 \\
\hline $\begin{array}{l}\text { HC- } \\
\text { FMUSP }_{6 h}\end{array}$ & $\begin{array}{l}1,044+2,150 \times \mathrm{C} 0.33+0 \\
, 601 \times \mathrm{C} 1.5+0,836 \mathrm{xC} 2+ \\
1,107 \times \mathrm{C} 3+2,337 \mathrm{xC} 4+3 \\
, 454 \times \mathrm{C} 6\end{array}$ & $55 \pm 36$ & NS & $+2.2 \pm 16$ & 90 & 44 \\
\hline $\begin{array}{l}\text { HC- } \\
\text { FMUSP }_{4 h}\end{array}$ & $\begin{array}{l}-1,844+1,683 \times \mathrm{C} 0+1,83 \\
6 \mathrm{xC} 0,66+0,752 \times \mathrm{CC} 1.5+ \\
0,924 \times \mathrm{C} 22+0,380 \times \mathrm{C} 3+5 \\
, 852 \times \mathrm{C} 4\end{array}$ & $60 \pm 42$ & 0.002 & $+6.6 \pm 22$ & 73 & 36 \\
\hline $\begin{array}{l}\text { Li Am J } \\
\text { Nephrol, } 2013\end{array}$ & $\begin{array}{l}-3.63+8.35 \mathrm{xC} 4+17.04 \mathrm{x} \\
\mathrm{C} 7+13.74 \mathrm{xC} 12\end{array}$ & $121 \pm 94$ & 0.000 & $69 \pm 68$ & 11 & 4 \\
\hline
\end{tabular}

CITATION INFORMATION: David-Neto E, Triboni A, Ramos F, Agena F, Romano P, Freitas G. A Critical Analysis of Equations for MPA Exposure in Patients Under EC-MPS and Tacrolimus Am J Transplant. 2017;17 (suppl 3). 


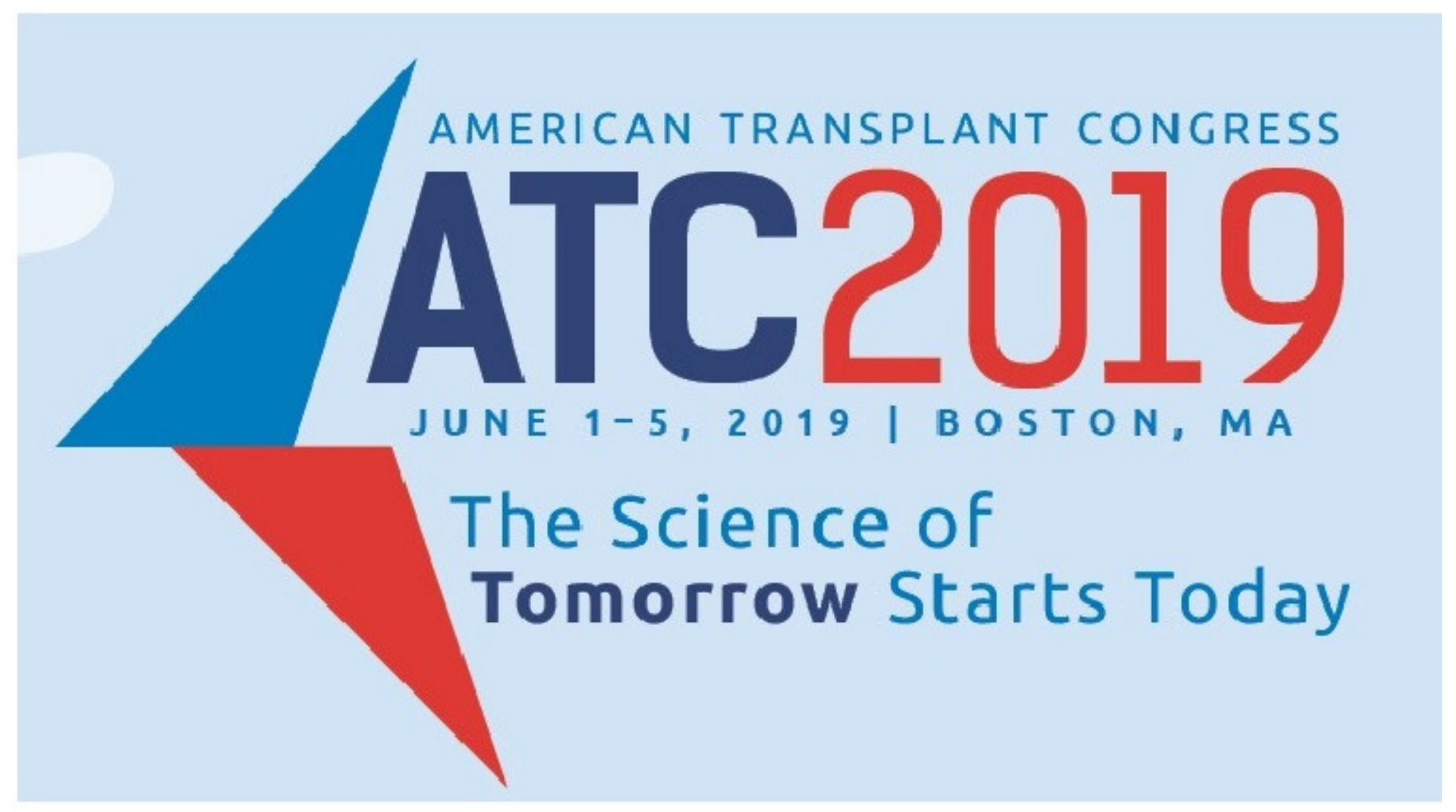

Disponível em:

https://onlinelibrary.wiley.com/toc/16006143/2019/19/S3 
POSTER SESSION D: LYMPHOCYTE BIOLOGY: SIGNALING, CO-STIMULATION, REGULATION

validated by qPCR in an independent set of patients. To analyze the genome-wide expression of CD8 $+\mathrm{T}$ lymphocytes isolated, we enrolled an independent cohort of 4 CAMR patients and 4 control subjects. The remaining patients were employed to validate the microarray data by qPCR.

Results: Gene expression profiles of CD8+ T cells revealed that triacylglycerol biosynthesis ( $p=2.69 \mathrm{E}-3)$ was the main dysregulated canonical pathway. Among the main diseases and bio-functions pathways, deregulation of the lipid metabolism features the CAMR patients. In this setting we observed a significant change in the genes related to the release of prostaglandins $(\mathrm{p}=5.3 \mathrm{E}-5)$, in particular prostaglandin E2 ( $p=2.95 \mathrm{E}-4)$, and the release of eicosanoids $(\mathrm{p}=4.41 \mathrm{E}-4)$. The main genes involved in these metabolic pathways were $\mathrm{CERK}(\mathrm{FC}=-2.7), \mathrm{HMGB} 1(\mathrm{FC}=+2.02)$, LPIN1 $(\mathrm{FC}=+2.07)$, NAMPT $(\mathrm{FC}=+2.39)$, TNFSF10 $(\mathrm{FC}=+2.07)$. All the changes in the expression of these genes in CAMR vs control patients was confirmed by qPCR $(\mathrm{p}<0.05)$.

Conclusions: In conclusion, our data would suggest a significant change in CD8+ activation in CAMR patients mainly characterized by a marked deregulation of lipid-related metabolic pathways. This observation may suggest that metabolic alterations may influence immune response in CAMR as already described for autoimmune diseases.

CITATION INFORMATION: Pontrelli P., Rascio F., Accetturo M., Castellano G., Simone S., Stallone G., Gesualdo L., Grandaliano G. Gene Expression Profiles in CD8+ T Cells in Chronic Antibody-Mediated Rejection (CAMR) of Kidney Transplantation Am J Transplant. 2019;19(suppl 3).

DISCLOSURES: P. Pontrelli: None. F. Rascio: None. M. Accetturo: None. G. Castellano: None. S. Simone: None. G. Stallone: None. L. Gesualdo: None. G. Grandaliano: None.

\section{Abstract\# D142 \\ Sphingosine 1-Phosphate Receptors and CCR7 Sequentially Coordinate T Cell Migration.}

Y. Xiong ${ }^{1}$, W. Piao ${ }^{1}$, C. Brinkman 1 , J. Kulinski ${ }^{2}$, A. Olivera ${ }^{2}$, A. Cartier ${ }^{3}$,

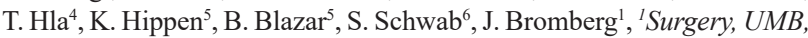
Baltimore, MD, ${ }^{2} \mathrm{NIH}$, Bethesda, MD, ${ }^{3}$ Boston Children's hospital, Boston, MA, ${ }^{4}$ Boston Children's hospital, Boston, MD, ${ }^{5}$ U.Minnesota, Minneapolis, $M N,{ }^{6} N Y U, N Y, N Y$

Purpose: CCR7 plays critical roles in T cell migration to CCL21 across lymphatic endothelial cells from tissues to lymph nodes (LN). S1PR1 and S1PR4 are also required by $\mathrm{T}$ cells for $\mathrm{S} 1 \mathrm{P}$-driven afferent lymphatic migration. However, the distinct roles of CCR7 and S1PRs on T cell LN homing have not been defined yet. We hypothesized that CCR7 and S1PRs have unique roles on T cell transendothelial migration (TEM).

Methods: CD4 T cells were adoptively transferred into mice, and migration to afferent lymphatics and draining LN (dLN) measured. Mouse primary lymphatic endothelial cells (LEC) and LEC lines were used to assess migration, chemokine signals, adhesion molecules and S1PR and CCR7 function in vitro. Specific pharmacologic and genetic blockade were employed.

Results: S1P, but not CCL19, promoted T cell interaction with LEC to enhance TEM. VCAM-1, not ICAM-1, promoted T cell migration toward S1P. An S1PR1 antagonist increased migration through VCAM-1, suggesting S1PR1 regulated binding and/or release of T cells from adhesion. In contrast, an S1PR4 inhibitor blocked migration, so S1PR4 was responsible for migration to VCAM-1. S1PR1 regulated migration distances but not velocities, while S1PR4 regulated both distances and velocities. S1P driven TEM was dependent on both chemotaxis and chemokinesis, and both S1PR1 and S1PR4 were required for chemotaxis and chemokinesis. Both S1PR1 and S1PR4 were required for T cell migration toward S1P or S1P plus CCL19. Kinetic analyses showed that S1PR1 and S1PR4 engaged T cell migration at early time points, while CCR7 was required at later time points. Although both S1P and CCL19 regulated T cell mobility, S1P-driven migration of CD4 T cells preferentially utilized transcellular rather than paracellular trafficking compared to CCL19. S1PR1 and S1PR4 antagonist treatment reduced the percentage of transcellular migration toward S1P. Conclusions: S1PRs and CCR7 play unique roles in T cell TEM migration. S1PRs initiate T cell-LEC interactions at early time points, while CCR7 drives T cells migration at these and later time points. S1PRs drive a unique transendothelial path compared to CCR7. These findings resolve uncertainties about why so many chemokines and receptors are required for migration, and point to new therapeutic approaches to regulate migration and immunity.

CITATION INFORMATION: Xiong Y., Piao W., Brinkman C., Kulinski J., Olivera A., Cartier A., Hla T., Hippen K., Blazar B., Schwab S., Bromberg J. S. Sphingosine 1-Phosphate Receptors and CCR7 Sequentially Coordinate T Cell Migration Am J Transplant. 2019;19(suppl 3).

DISCLOSURES: Y. Xiong: None. W. Piao: None. C. Brinkman: None. J. Kulinski: None. A. Olivera: None. A. Cartier: None. T. Hla: None. K. Hippen: None. B. Blazar: None. S. Schwab: None. J. Bromberg: None.

\section{Abstract\# D143}

Thymoglobulin Induction with Tacrolimus and Everolimus Maintenance Therapy in Elderly Kidney Transplantation Results in Prolonged Lymphocyte Depletion and Do Not Favor Regulatory Profile.

E. David-Neto ${ }^{1}$, G. Ramos de Freitas ${ }^{1}$, M. Fernandes ${ }^{1}$, F. Agena ${ }^{1}$, F. Brambate Carvalhinho Lemos ${ }^{1}$, F. Jota de Paula', V. Coelho' ${ }^{2}$ N. Zocoler Galante ${ }^{1},{ }^{1}$ Renal Transplantation Service, Hospital das Clínicas - University of São Paulo School of Medicine, Sao Paulo, Brazil, ${ }^{2}$ Laboratory of Immunology - LIM 19, Heart Institute - University of São Paulo School of Medicine, Sao Paulo, Brazil

Purpose: Despite the growing number of elderly kidney transplant (Ktx) recipientes few studies describe the effects of immunosuppression on this group. We evaluated the immunological effects of rabbit antithymocyte globulin (rATG) induction and early everolimus(EVL) conversion in elderly individuals.

Methods: We compared three groups of KTx patients: a- Non-Elderly ( $\mathrm{n}=20,36 \pm 7 \mathrm{y}$ ) receiving standard immunosuppression (SIS) (prednisone, tacrolimus and mycophenolate sodium) (Non-Elderly); b- Elderly receiving SIS ( $\mathrm{n}=35,65 \pm 3 \mathrm{y}$ ) (Elderly SIS) or c- Elderly SIS with early mycophenolate to EVL conversion (EEC) (Elderly EEC) $(\mathrm{n}=16,65 \pm 3 \mathrm{y})$. At 365 days(d) elderly ISIS were 19 , since 16 were converted to EVL. All with a single dose of rATG $2,0 \mathrm{mg} / \mathrm{Kg}$. Naïve, memory and regulatory peripheral blood T lymphocytes were analyzed at $0 \mathrm{~d}, 30 \mathrm{~d}$ and $365 \mathrm{~d}$ after Ktx.

Results: Elderly SIS presented lowering of lymphocyte absolute counts within 30 days(d) [1310(1000-16000) vs. 910 (700-11980) cells $\left./ \mathrm{mm}^{3}, \mathrm{p}=0.0012\right]$, but within $365 \mathrm{~d}$ there was no difference compared to baseline neither in Elderly SIS [1130(4601325) cells $\left./ \mathrm{mm}^{3}, \mathrm{p}=0.62\right]$ nor in those switched to Elderly EEC [1410(805-1895) cells $/ \mathrm{mm}^{3}, \mathrm{p}>0.99$ ] groups. Non-Elderly absolute counts did not change over time [2100(1630-2400) vs $1960(1270-2970)$ vs $1850(1590-2120)$ cells $\left./ \mathrm{mm}^{3}\right]$. T central memory percentages decreased within $30 \mathrm{~d}$ for Non-Elderly [6.2(3.77-10.8) vs $5.32(2.49-7.28) \%$ of $\left.\mathrm{CD}^{+}, \mathrm{p}=0.036\right]$ and Elderly SIS $[8.17(5.28-12.88)$ vs 6.74(4.36$11) \%$ of $\mathrm{CD}^{+}, \mathrm{p}=0.05$ ], but at $365 \mathrm{~d}$ returned to baseline. At $365 \mathrm{~d}$ Elderly SIS presented higher percentages of $\mathrm{T}$ central memory cells compared to Non-Elderly [21.2(10.94-27.95) vs 8.62(4.95-13.5) \% of $\left.\mathrm{CD}^{+}, \mathrm{p}=0.048\right]$, but lower percentages of TEMRA cells [7.22(5.55-11.4) vs $15.7(9.05-30.2) \%$ of $\left.\mathrm{CD}^{+}, \mathrm{p}=0.048\right]$. Regulatory CD $39^{+} \mathrm{T}$ cells (TREG) percentages decreased within 30d in Elderly SIS [2.01(1.23$3.51)$ vs $1.69(0.8-2.66) \%$ of $\left.\mathrm{CD}^{+}, \mathrm{p}=0.0028\right]$ and Non-Elderly $[1.29(0.45-1.85)$ vs $0.84(0.18-1.82) \%$ of $\left.\mathrm{CD}^{+}, \mathrm{p}=0.0038\right]$ and within $365 \mathrm{~d}$ returned to baseline in Elderly SIS and EEC groups. In Non-Elderly regulatory $\mathrm{CD} 39^{+} \mathrm{T}$ cells remained decreased at $356 \mathrm{~d}$ [vs $0.86(0.70-1.34) \%$ of $\left.\mathrm{CD}^{+}, \mathrm{p}=0.0156\right]$ ].

Conclusions: Lymphocyte repopulation time after rATG suggests that usual rATG dose in elderly recipient should be revised in spite of the maintenance immunosuppression regimen. In this study, it was not observed a favorable effect of rATG or EVL conversion on TREG profile. Otherwise, rATG affected memory subsets. Aging favored TREG maintenance on late transplantation period and seemed to occur despite of maintenance immunosuppression.

CITATION INFORMATION: David-Neto E., Ramos de Freitas G. R., Fernandes M. d. L., Agena F., Brambate Carvalhinho Lemos F., Jota de Paula F., Coelho V., Zocoler Galante N. Thymoglobulin Induction with Tacrolimus and Everolimus Maintenance Therapy in Elderly Kidney Transplantation Results in Prolonged Lymphocyte Depletion and Do Not Favor Regulatory Profile Am J Transplant. 2019;19(suppl 3). DISCLOSURES: E. David-Neto: None. G. Ramos de Freitas: None. M. Fernandes: None. F. Agena: None. F. Brambate Carvalhinho Lemos: None. F. Jota de Paula: None. V. Coelho: None. N. Zocoler Galante: None.

\section{Abstract\# D144 \\ Inhibition of Th1 and Th17 Cell Differentiation and Prolonged Graft Survival through NFAT Pathway Downregulation.}

C. Dai ${ }^{1}$, R. Tan 1 , B. Yang ${ }^{1}$, J. Markmann', D. Chen ${ }^{1}$, L. Wei ${ }^{1}$, Z. Chen ${ }^{1}$, ${ }^{1}$ Institute of Organ Transplantation, Wuhan, China, ${ }^{2}$ Division of Transplantation, Boston, American Samoa

Purpose: Extracts Aglaia (family Meliaceae) plants, specially Rocaglamide are used treatment strategy of autoimmune Inflammatory disease and allergic disease in traditional medicine in many Asia countries. Lots of autoimmune Inflammatory disease have been associated with promotion of $\mathrm{T}$ cell activity and cytokines, particularly IL-4 and IL-6 in vivo. Recently, many studies have demonstrated that purification rocaglamide are immunosuppressive that suppress levels of the Th1-type cytokine IFN- $\gamma$, IL-2 and IL-6 in peripheral blood T cells. Therefore, we hypothesized that rocaglamide prolong graft survival time in the heart transplantation model. We also found that rocaglamide can down-regulate the Th-1 cells, Th-17 cells and memory $\mathrm{T}$ cells in the spleen as well as Lymph nodes, which is been associated with the suppressive of rocaglamide inhibit NF-AT activation in T cells.

Methods: Recipients were treated with PBS $(\mathrm{n}=6)$ and rocaglamide $(\mathrm{n}=8)$ for survival studies. Heart grafts were monitored until they stopped beating. grafts were performed, and recipients were sacrificed on days 7 for histological ,MLR,ELISA and flow cytometric analyse.

Results: The administration of rocaglamide significantly prolonged the grafts from 7 to 25 days (median survival), compared to control group ( $\mathrm{P}<0.001)$. On day 7 post-transplant, grafts of mice treated with rocaglamide showed a significantly 


\title{
Aging and End Stage Renal Disease Cause A Decrease in Absolute Circulating Lymphocyte Counts with A Shift to A Memory Profile and Diverge in Treg Population
}

\author{
Geraldo Rubens Ramos Freitas ${ }^{1,2}$, Maria da Luz Fernandes², Fabiana Agena ${ }^{2}$, Omar Jaluul ${ }^{3}$, \\ Sérgio Colenci Silva ${ }^{3}$, Francine Brambate Carvalhinho Lemos ${ }^{2}$, Verônica Coelho ${ }^{4}$, Elias David- \\ Neto $^{2}$, Nelson Zocoler Galante, ${ }^{2, *}$
}

${ }^{1}$ Division of Nephrology, and ${ }^{2}$ Renal Transplant Service, Hospital das Clinicas, University of Sao Paulo School of Medicine, Sao Paulo, Brazil. ${ }^{3}$ Division of Geriatrics, Hospital das Clinicas, University of Sao Paulo School of Medicine, Sao Paulo, Brazil. ${ }^{4}$ Laboratory of Immunology, Heart Institute, University of Sao Paulo School of Medicine. Institute for Investigation in Immunology, Sao Paulo, Brazil.

[Received January 10, 2018; Revised March 6, 2018; Accepted March 18, 2018]

\begin{abstract}
There is a growing number of elderly kidney transplant (Ktx) recipients. Elderly recipients present lower acute rejection rates but higher incidence of infection and malignancies. Aging per se seems to result in a shift to memory profile and chronic kidney disease (CKD) in premature immunological aging. Understanding aging and CKD effects on the immune system can improve elderly Ktx immunosuppression. We analyzed the effects of aging and CKD in the immune system, comparing healthy adults (HAd) (n=14, 26 $\pm 2 y$ ), healthy elderly (HEld) $(n=15,79 \pm 7 y)$, end stage renal disease (ESRD) adults $($ EnAd) $(n=18,36 \pm 7 y)$ and ESRD elderly (EnEld) $(n=31,65 \pm 3 y)$ prior to $K t x$ regarding their naïve, memory and regulatory $T$ and $B$ peripheral lymphocytes. Aging and ESRD presented additive effect decreasing absolute numbers of $B$ and T-lymphocytes, affecting memory, naive and regulatory subsets without synergic effect. Both resulted in higher percentages of $T$ memory subsets and opposing effects on regulatory $T$ (TREG) subsets, higher percentage in aging and lower in ESRD. Combined effect of aging and ESRD also resulted in higher regulatory B cell percentages. In addition to global lymphopenia and $\mathrm{TCD4}^{+}$memory shift in both aging and ESRD, aging shifts to an immunoregulatory profile, inducing a increase in TREG percentages, contrasting with ESRD that decreases TREGs. Differential immunosuppression regimens for elderly Ktx may be required. (ClinicalTrials.gov number: NTC01631058).
\end{abstract}

Key words: T lymphocytes, B lymphocytes, Chronic Kidney Disease, Kidney transplantation, Immune senescence.

A challenge in kidney transplantation is to improve the short- and long-term outcomes for elderly recipients. The rates of infection [1] and malignancy [2] after transplantation are significantly higher among elderly recipients and acute rejection episodes are less frequently reported [3].

Although these events are often attributed to overimmunosuppression with lower clearance of drugs [4, 5], aging influences many aspects of the immune system, including lymphocyte counts, subset differentiation and function.

Studies with healthy volunteers have shown that aging is followed by a progressive T-cell lymphopenia in peripheral blood, with accumulation of memory $\mathrm{T}$ lymphocytes in contrast to naive T-cells $[6,7]$. T-cells with cell surface expression of regulatory markers have also shown to be more frequent among healthy elderly [8].

*Correspondence should be addressed to: Dr. Nelson Zocoler Galante, Serviço de Transplante Renal-Hospital das Clínicas-Faculdade de Medicina da Universidade de São Paulo, Brasil. Email: nelson.galante@hc.fm.usp.br

Copyright: () 2018 Freitas GRR et al. This is an open-access article distributed under the terms of the Creative Commons Attribution License, which permits unrestricted use, distribution, and reproduction in any medium, provided the original author and source are credited. 
Information about the effect of aging on Blymphocytes is conflicting. In most studies B-cell lymphopenia is a common finding among healthy elderly $[9,10]$, but both age-related increase $[10,11]$ and decrease $[12,13]$ in B-cells with memory phenotype have been reported. Little is available about the effects of aging among B-cells with expression of regulatory markers.

End stage renal disease (ESRD) also induces phenotype and functional changes in peripheral lymphocytes. Although most studies agree that a T-cell lymphopenia accompanies the progressive loss of renal function [14-16], the numbers of naive T-cells have been reported to be reduced $[17,18]$ or unchanged $[16]$ among ESRD. There is also no agreement regarding the frequencies of memory T-cells among uremic patients. Chung et al. reported that central memory and effector memory T-lymphocytes accumulate in peripheral blood of uremic patients as compared to healthy controls [18], whereas Yoon et al. showed a significant reduction of the same populations among uremic patients [17]. Also, the numbers of regulatory T-cells have been reported to be decreased compared to healthy controls, but with unchanged relative percentages [15]. Also, a decrease in naive B-cell population has been reported [19], as well as a reduction in the percentage of memory and regulatory B-cells in uremic patient [20].

Recently lymphocyte profiles have been associated with allograft outcomes. Memory subsets of $\mathrm{T}$ cells have been related to acute rejection occurrence and resistance to tolerance induction in graft recipients [21, 22]. Among $\mathrm{TCD}^{+}$memory lymphocytes, subpopulations can be predominantly found in lymphoid tissue ( $\mathrm{T}$ central memory) or in non-lymphoid tissue ( $\mathrm{T}$ effector memory), but their specific roles modifying allograft outcomes is still poor defined. Greater interstitial infiltration of B cells with $\mathrm{CD}_{27} 7^{+}$(memory) and $\mathrm{CD} 38^{+}$expression are commonly found in acute cellular rejection of kidney allografts and correlate with lower steroid response [23]. The higher occurrence of regulatory $\mathrm{T}$ cells $\left(\mathrm{CD} 4{ }^{+} \mathrm{CD} 25^{+} \mathrm{FoxP} 3^{+}\right)$correlates with stable graft function and immune tolerance occurrence [24], greater glomerular filtration rates and lower acute rejection incidence [25]. Also, relative higher regulatory B cells $\left(\mathrm{CD} 19^{+} \mathrm{CD} 24^{\mathrm{Hi}} \mathrm{CD} 38^{\mathrm{Hi}}\right)$ occurrence relates to stable graft function [26] and operational tolerance [27].

Elderly recipients present different clinical outcomes compared to younger counterparts and both, ESRD and aging may change lymphocyte subsets profile. Characterizing the lymphocyte subset changes in ESRDaging co-occurrence would help to understand these clinical discrepancies.

Lymphocyte subset characterization, patient selection, degree of renal dysfunction and disease definition among available studies is quite variable, making comparisons difficult. Also, the effects of aging or chronic kidney disease (CKD) were assessed separately in different studies and no studies analyzed the T- and Bcell compartment simultaneously.

In this study, we analyzed, all together, the effects of aging and ESRD in the subsets of peripheral blood $\mathrm{T}$ and B lymphocytes. The comprehension of these variables effects on lymphocyte profile may be determinant to immunosuppression individualization of elderly kidney transplant recipients.

\section{MATERIAL AND METHODS}

\section{Study design and population}

This is a cross-sectional study to investigate aging and ESRD related quantitative changes in peripheral blood Tand B-cell maturation stages comparing healthy subjects (healthy elderly and healthy younger adults) with ESRD patients (elderly and younger adults).

Healthy subjects and ESRD patients were enrolled at our hospital from September 2012 to July 2015. Fourteen healthy adults ( $>18$ and $\leq 45$ years) (HAd) and 15 healthy elderly ( $>60$ years) (HEld) participated in this study. Selfreports of health were used to assess the health condition of HAd. All HEld are volunteers regularly followed at the outpatient unit of the Geriatric Division of our institution and free of chronic illness, such as systemic arterial hypertension ( $\mathrm{SAH})$, diabetes mellitus (DM), malignancy or psychiatric disorders. All healthy subjects also did not present chronic viral infections or had presented acute illness or been vaccinated for at least 60 days. Healthy subjects were free of any medication for at least 6 months.

Forty-nine patients with ESRD, already on dialysis, were recruited at hospital admission for their first kidney transplantation. Eighteen were younger ESRD adult patients (EnAd), and 31 were ESRD elderly patients (EnEld). The elderly recipients were those included in the nEverOld study [28] (Clinical Trials identifier: NTC01631058).

The study was approved by institutional board of ethics in research. All individuals provided informed consent prior to enrollment.

\section{Blood collection and cell preparation}

A sample of $20 \mathrm{~mL}$ of heparinized whole blood was collected from healthy subjects at study recruitment, and immediately prior to kidney transplantation from ESRD patients. Total leukocyte and lymphocyte counts were performed according to standard methods. Peripheral blood mononuclear cells (PBMC) were separated by Ficoll density gradient centrifugation and cryopreserved for further analysis. 

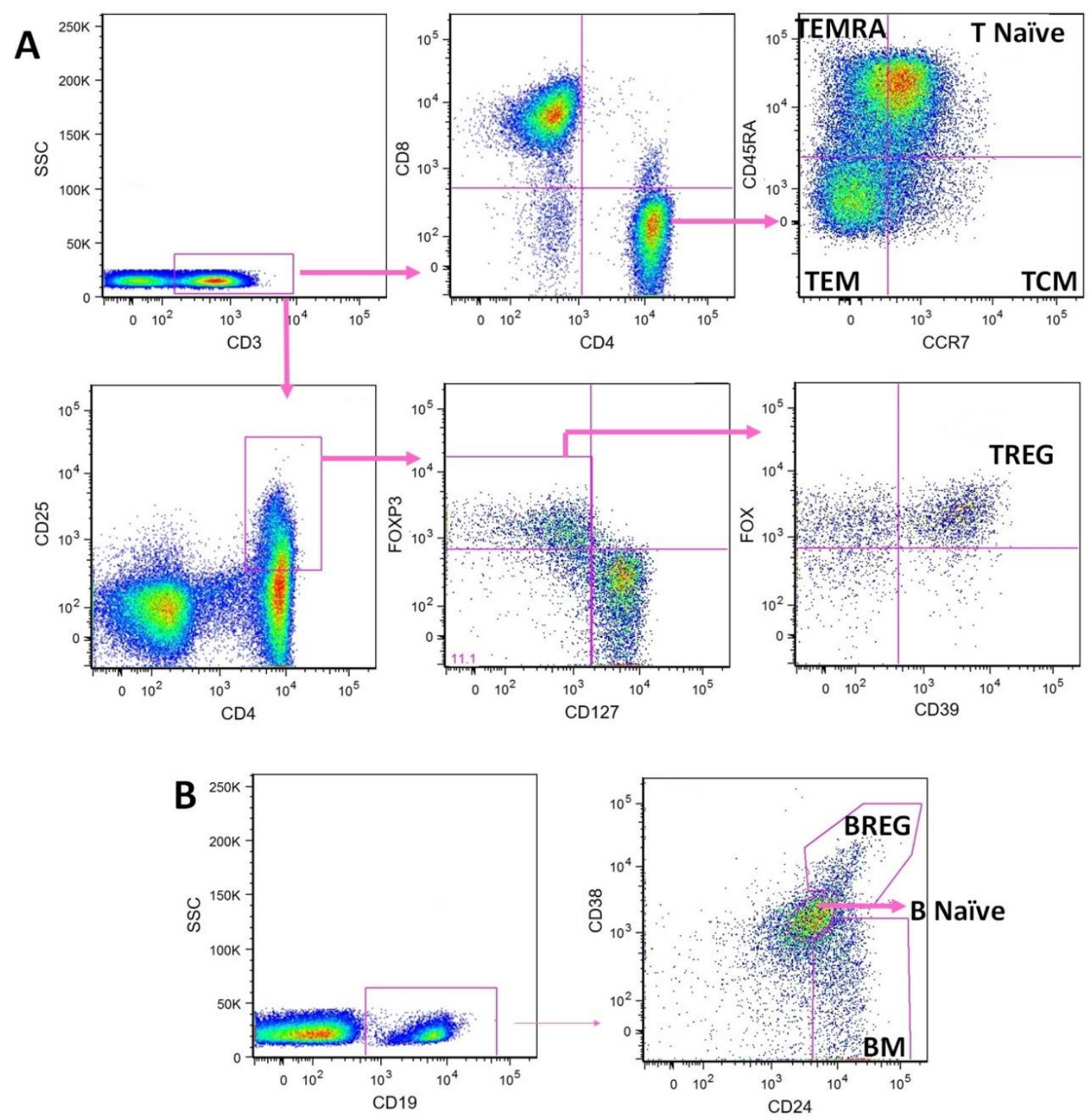

Figure 1. Flow cytometry characterization of peripheral blood $\mathbf{T}$ and $\mathbf{B}$ cell subsets. Fluorescence minus one (FMO) controls were set up for CD127, FoxP3, CD39, CCR7 (CD197) and CD45RA. Panel A represents the strategy for $\mathrm{T}$ cell subsets characterization and panel B for B cell subsets characterization. TCM - T central memory, TEM - T effector memory, TEMRA - T effector memory with RA reexpression, TREG - regulatory $\mathrm{T}$ cells, BM - B memory, BREG - regulatory B cells.

Flow cytometry identification of T- and B-lymphocytes subpopulations

PBMC were thawed, washed, and then stained with titrated mouse anti-human monoclonal antibodies. AntiCD4-fluorescein isothiocyanate (FITC) (OKT4), antiCD19-FITC (HIB19), anti-CCR7 (CD197)Phycoerythrin (PE) (3D12), anti-CD45RA-PE-Cy7 (HI100), anti-CD25-PE (BC96), anti-CD127-PE-Cy7
(RDR5), anti-FoxP3-Peridinin Chlorophyll Protein Complex (PerCp)-Cy5.5 (PCH101) and anti-CD39allophycocyanin (APC) (A1) antibodies were from eBiosciences (San Diego, CA, USA). Anti-CD3-APCCy7 (SK7), anti-CD8-AmCyan (SK1), anti-CD24-PECy7 (ML5), anti-CD38-PerCp-Cy5.5 (HIT2) and BD Multitest $^{\mathrm{TM}}$ CD3/CD8/CD45/CD4 [anti-CD3-FITC (SK7), anti-CD8-PE (SK1), anti-CD45-PerCP (2D1 (HLe-1)) and anti-CD4-APC (SK3)] were from BD 
Biosciences (Heidelberg, Germany). For intra-cellular staining of FOXP3, cells were washed, fixed and permeabilized with Foxp3 staining buffer from eBioscience (San Diego, CA, USA) immediately after surface-staining. At least $0.5 \times 10^{5}$ events in the lymphocyte region were acquired. Fluorescence minus one (FMO) controls were set up for CD127, FoxP3, CD39, CCR7 (CD197) and CD45RA markers.

Table 1. Demographic data.

\begin{tabular}{|c|c|c|c|c|c|}
\hline & HAd $(n=14)$ & HEld $(n=15)$ & $\operatorname{EnAd}(n=18)$ & EnEId $(n=31)$ & $\mathrm{P}$ \\
\hline Age (years) & $26 \pm 2$ & $79 \pm 7^{\mathrm{a}}$ & $36 \pm 7^{\mathrm{b}, \mathrm{d}}$ & $65 \pm 3^{\mathrm{c}, \mathrm{e}, \mathrm{f}}$ & $<0.001$ \\
\hline Gender (Male) n (\%) & $5(36)$ & $1(7)$ & $7(39)^{\mathrm{d}}$ & $18(58)^{\mathrm{e}}$ & 0.01 \\
\hline BMI $\left(\mathrm{Kg} / \mathrm{m}^{2}\right)$ & --- & --- & $24(22.4-25.6)$ & $25(22.8-27.2)$ & $0.206^{\#}$ \\
\hline \multicolumn{6}{|l|}{ Comorbidities } \\
\hline SAH n $(\%)$ & 0 & 0 & $16(89)^{\mathrm{b}, \mathrm{d}}$ & $31(100)^{, \mathrm{e}}$ & $<0.001$ \\
\hline Diabetes mellitus n (\%) & 0 & 0 & $3(17)$ & $15(48)^{\mathrm{c}, \mathrm{e}}$ & $<0.001$ \\
\hline Glomerulopathy n (\%) & 0 & 0 & $3(17)$ & $2(7)$ & 0.107 \\
\hline ADPKD n (\%) & 0 & 0 & $1(6)$ & $2(7)$ & 0.41 \\
\hline \multicolumn{6}{|l|}{ Renal replacement data } \\
\hline Time on RRT (months) & --- & --- & $32(14-45.5)$ & $36(21-54)$ & $0.23^{\#}$ \\
\hline RRT (HD) n (\%) & --- & --- & $17(94)$ & $28(90)$ & $1.0^{\#}$ \\
\hline \multicolumn{6}{|l|}{ Laboratorial data } \\
\hline Albumin & --- & --- & $4.4(4.17-4.62)$ & $4.3(3.6-4.7)$ & $0.4^{\#}$ \\
\hline Hemoglobin & --- & --- & $12.2(9.9-13.1)$ & $12.6(11-12.9)$ & $0.88^{\#}$ \\
\hline PTH & --- & --- & $236(80.5-608)$ & $237(130-574)$ & $0.868^{\#}$ \\
\hline
\end{tabular}

HAd - healthy adults; HEld - healthy elderly; EnAd - end stage renal disease adult patients; EnEld - end stage renal disease elderly patients, BMI - body mass index, SAH - systemic arterial hypertension, ADPKD - Autosomal dominant polycystic kidney disease, RRT - renal replacement therapy, HD - hemodialysis, PTH - parathyroid hormone.

${ }^{\#}$ Comparison of EnAd and EnEld only

a Significant difference between: ${ }^{\mathrm{a}} \mathrm{HAd}$ and HEld; ${ }^{\mathrm{H} A d}$ and EnAd; ${ }^{\mathrm{H}} \mathrm{HAd}$ and EnEld; ${ }^{\mathrm{H}} \mathrm{HEld}$ and EnAd; ${ }^{\mathrm{e}} \mathrm{HEld}$ and EnEld; fEnAd and EnEld.

Flow cytometry was performed in FACSCanto-II (BD Biosciences) cytometer. We used FlowJo 9.1 software (TreeStar Inc, San Carlos, CA, USA) for analysis. After exclusion of cell doublets and debris, sequential gating of PBMC was performed in the lymphocyte region. The gating strategies used to define $\mathrm{T}$ - and B-cell subsets are shown in Figure 1. The lymphocyte evaluated were $\mathrm{T}\left(\mathrm{CD} 45^{+} \mathrm{CD} 3^{+}\right)$, TCD8 $\left(\mathrm{CD} 45^{+} \mathrm{CD}^{+}{ }^{+} \mathrm{CD} 8^{+}\right), \quad \mathrm{TCD} 4 \quad\left(\mathrm{CD} 45^{+} \mathrm{CD}^{+}{ }^{+} \mathrm{CD} 4^{+}\right), \quad \mathrm{B}$ $\left(\mathrm{CD} 19^{+}\right)$and the subpopulations TCD4 naive $\left(\mathrm{CD}^{+}\right.$ $\mathrm{CD} 4{ }^{+} \mathrm{CCR} 7{ }^{+} \mathrm{CD} 45 \mathrm{RA}^{+}$) (T naive), TCD4 central memory (TCM) $\left(\mathrm{CD}^{+}{ }^{+} \mathrm{CD} 4{ }^{+} \mathrm{CCR} 7{ }^{+} \mathrm{CD} 45 \mathrm{RA}^{-}\right)$, TCD4 effector memory (TEM) $\left(\mathrm{CD}^{+}{ }^{+} \mathrm{CD} 4{ }^{+} \mathrm{CCR} 7^{-} \mathrm{CD} 45 \mathrm{RA}^{-}\right), \quad \mathrm{TCD} 4$ effector memory with RA reexpression (TEMRA) $\left(\mathrm{CD} 3{ }^{+} \mathrm{CD} 4^{+} \mathrm{CCR} 7{ }^{-} \mathrm{CD} 45 \mathrm{RA}^{+}\right)$, regulatory TCD4 (TREG) $\left(\mathrm{CD} 3{ }^{+} \mathrm{CD} 4{ }^{+} \mathrm{CD} 25^{\mathrm{hi}} \mathrm{CD} 127-{ }^{-}\right.$oxP $\left.3{ }^{+} \mathrm{CD} 39^{+}\right), \quad \mathrm{B}$ naive $\left(\mathrm{CD} 19^{+} \mathrm{CD} 24^{\text {int }} \mathrm{CD} 38^{\text {int }}\right), \quad \mathrm{B}$ memory $(\mathrm{BM})$ $\left(\mathrm{CD} 19^{+} \mathrm{CD} 24^{+} \mathrm{CD} 38^{-}\right)$and regulatory $\mathrm{B}$ cells (BREG) $\left(\mathrm{CD} 19^{+} \mathrm{CD} 24^{\mathrm{hi}} \mathrm{CD} 38^{\mathrm{hi}}\right)$.
Lymphocyte subsets absolute counts were calculated using the percentages obtained in flow cytometry and the lymphocyte counts achieved in standard method blood counts on fresh blood before PBMC separation. The subset percentages analyzed were referred to total lymphocyte counts for T, TCD4, TCD8 and B cells, to TCD4 cells for T naïve, TCM, TEM and TEMRA, to $\mathrm{CD} 4{ }^{+} \mathrm{CD} 25^{+}$cells for TREG and to $\mathrm{B}$ cells for $\mathrm{B}$ naive, $\mathrm{BM}$ and BREG.

\section{Statistical analysis}

Kolmogorov-Smirnov or Shapiro-Wilk tests were used to test for normal distribution of continuous variables. The non-normally distributed variables underwent logtransformation to normalize the distribution, and the logtransformed data were compared when appropriate. Student's t-test was used to compare normally distributed continuous variables and Mann-Whitney U-test was used for non-normally distributed variables. The Chi-square or 
Fisher's exact test were used to compare nominal variables. Two-way analysis of variance (ANOVA) was used to test for aging vs ESRD interactions. Data are presented as medians and interquartile ranges [median (p25-p75)]. A p value $<0.05$ was considered significant. To evaluate aging effects HAd was compared with HEld and EnAd with EnEld. To evaluate ESRD effects HAd was compared with EnAd and HEld with EnEld.

All analyses were performed with SPSS-20 (IBMCorp., Armonk, NY, USA) and GraphPad Prism 6 software (GraphPad Software Inc., La Jolla, CA, USA).

\section{RESULTS}

\section{Study population}

As expected median age was significantly lower for younger adults compared to elderly for both healthy volunteers [ $26 \pm 2$ vs. $79 \pm 7, \mathrm{p}<0.001]$ and ESRD patients [36 \pm 7 vs. $65 \pm 3, \mathrm{p}<0.001$ ]. HEld were older than EnEld, and EnAd were older than HAd. There was a higher prevalence of female in HEld. As expected, ESRD groups presented a high prevalence of SAH and DM. EnAd and EnEld did not differ in the prevalence of SAH, DM, glomerulopathy and autosomal dominant polycystic kidney disease (Table 1). All patients presented glomerular filtration rate lower than $15 \mathrm{ml} / \mathrm{min} / 1,73 \mathrm{~m}^{2}$ and were all on dialysis. ESRD groups presented similar time on renal replacement therapy, hemodialysis prevalence, body mass index, albumin, hemoglobin and parathyroid hormone levels. Specific dialysis data such as $\mathrm{Kt} / \mathrm{V}$, dialysis session duration or erythropoietin exposure were not available.

\section{The effects of aging in lymphocyte subpopulations}

\section{Healthy Individuals}

The effect of aging in healthy subjects were determined with comparison of HEld with HAd. HEld presented lower absolute counts of total lymphocytes, T, TCD4 and TCD8 lymphocytes (Fig. 2A), as well as lower absolute count (Table 2 and supplementary Fig. 2A) and percentage of TEMRA cells (Fig. 3A). Although the absolute counts of TCM and TREG cells (Table 2 and supplementary Fig. 2A and 2B) did not significantly differ, higher percentages of both populations were observed in the HEld (Fig. 3A and 3B). There were no significant differences among the B-cell subsets (Fig. 2B).

\section{ESRD individuals}

To determine the effect of aging on lymphocyte subpopulations of ESRD patients, we compared EnEld with EnAd. The aging effect in ESRD resembled those in healthy subjects. EnEld presented significant lower absolute counts of total lymphocytes, T, TCD4, TCD8 and B-cells (Fig. 2A), as well as lower absolute counts of TEM and TEMRA (table 2 and supplementary Fig. 2A). The absolute counts of TREG did not significantly differ (table 2 and supplementary Fig. 2B), but the percentages of cells with this phenotype were higher in the CD $4{ }^{+} \mathrm{CD} 25^{+}$population of EnEld (Fig. 3B). Significant lower absolute counts of $\mathrm{B}$ naive and $\mathrm{BM}$ subsets were also observed in EnEld (Table 2 and supplementary Fig. 1B). There were no significant differences in percentages of the B-cell subsets (Fig. 2B).

\section{The effect of ESRD in lymphocyte subpopulations}

Next, we determined the effect of ESRD in lymphocyte subpopulations of adults comparing ESRD patients with healthy subjects. The results of ESRD were very similar to those of aging.

\section{Adult individuals}

We first compared EnAd with HAd. We found that EnAd presented lower absolute counts of total, T, TCD4, TCD8 and B lymphocytes (Fig. 2A and Table 2). Among TCD4 cell subsets, EnAd presented lower absolute counts of T naive and TEMRA cells (Table 2 and supplementary Fig. 2A). Also, the absolute counts of TREG were not significantly different between groups (table 2 and supplementary Fig. 2B) but the percentage of cells with this phenotype was lower among EnAd (Fig. 3B). EnAd also presented lower absolute numbers of $B$ naive and $B M$ cells (Table 2 and supplementary Fig. 1B), but no significant differences among percentages of B-cell subsets (Fig. 2B).

\section{Elderly individuals}

To evaluate the effect of ESRD in lymphocyte subpopulations in the elderly cohorts, we compared EnEld with HEld subjects. EnEld presented lower absolute counts of total lymphocytes, T, TCD4 and B lymphocytes (Fig. 2A and Table 2), with lower B-cell percentage (supplementary Fig. 1A). Among TCD4, the absolute counts of $\mathrm{T}$ naive, TCM, TEMRA and TREG lymphocytes subsets were also lower (table 2 and supplementary Fig. 2A and 2B). EnEld presented a lower percentage of TREG lymphocyte compounds (Fig. 3B). Significant lower absolute counts of $\mathrm{B}$ naive, BM and BREG subsets (Table 2 and supplementary Fig. 1B) were also observed with no percentage differences (Fig. 2B). 


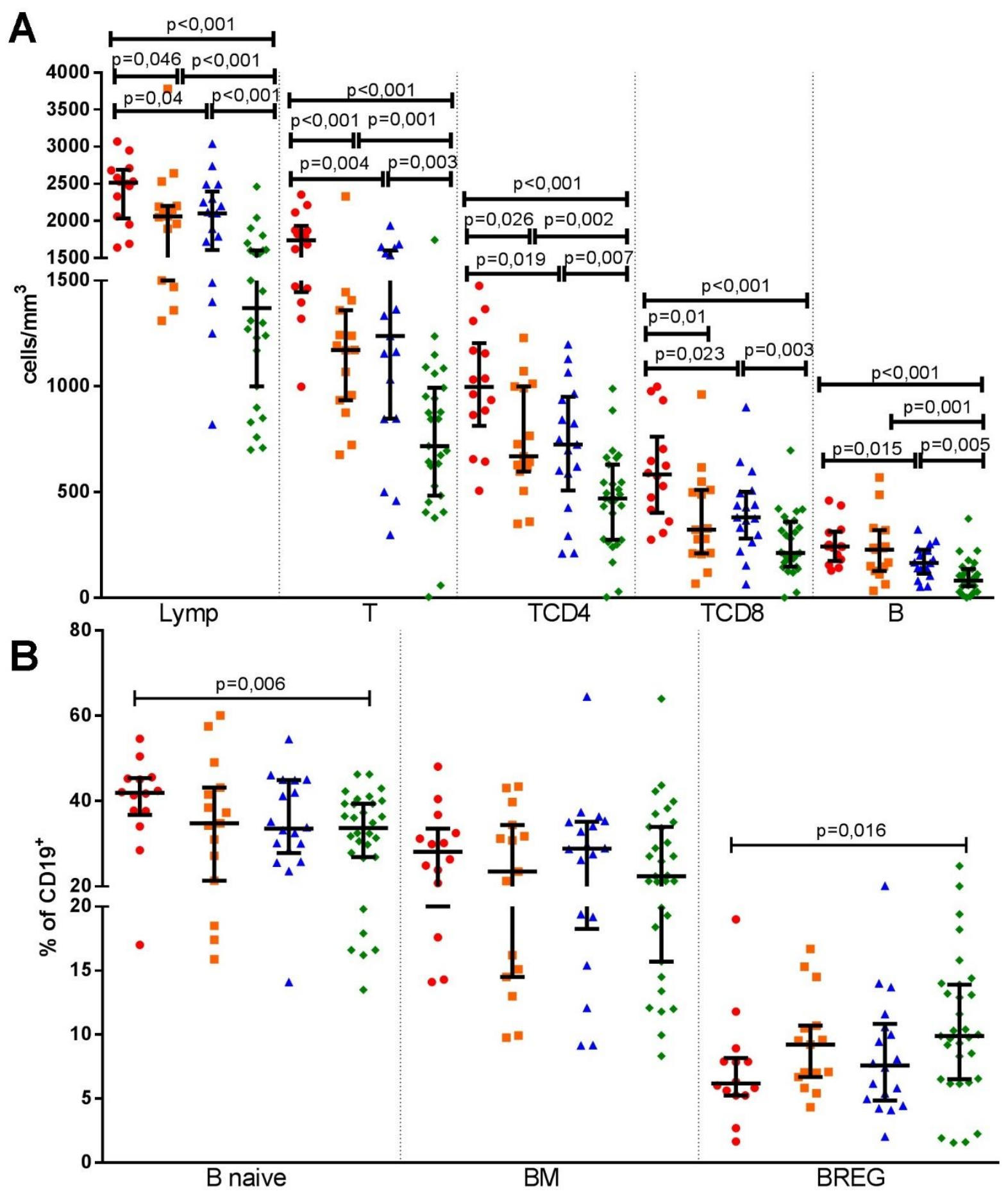

Figure 2. Aging and end stage renal disease effects in absolute total lymphocytes, T-, TCD4-, TCD8- and B- cells (A) and in B-cells subsets percentages $(B)$. Healthy adults $(n=14)(O)$, healthy elderly $(n=15)(\square)$, end stage renal disease adult patients $(n=18)(\boldsymbol{\Delta})$ and end stage renal disease elderly patients $(n=31)(\diamond)$ absolute counts and percentages are shown in the same repeatedly order in each cell subset analysis. Lymp - total lymphocyte, T - T lymphocyte, TCD4 - T helper, TCD8 - T cytotoxic, B - B lymphocyte, BM - B memory, BREG -regulatory B cells. Bars represent median and interquartile ranges. 


\section{The interaction of aging and ESRD in lymphocyte subpopulations}

We further investigated the combined effect of aging and ESRD in lymphocyte subpopulations comparing EnEld with HAd. EnEld presented lower absolute counts of total lymphocytes and all lymphocyte subpopulations, namely T, B, TCD4, TCD8, T naive, TCM, TEM, TEMRA, TREG, B naive, BM and BREG cells (Fig. 2A, supplementary Fig. 1B, 2A, 2B and Table 2).
EnEld also presented lower percentages of T, TCD8, TEMRA, B and B naive lymphocytes (Fig. 2B, Fig. 3A and supplementary 1A). Despite the general lower absolute counts in lymphocyte subpopulations, EnEld presented higher percentage of TEM and BREG lymphocytes (Fig. 2B and 3A). TREG percentages did not differ comparing EnEld with HAd (Fig. 3B).

Table 2. Effects of aging and end stage renal disease in the absolute numbers (cells $/ \mathrm{mm}^{3}$ ) of lymphocyte subpopulations among healthy adults, healthy elderly, adult ESRD patients and elderly ESRD patients.

\begin{tabular}{lllll}
\hline & HAd $(\mathrm{n}=14)$ & HEld $(\mathrm{n}=15)$ & EnAd $(\mathrm{n}=17)$ & EnEld $(\mathrm{n}=27)$ \\
\cline { 2 - 4 } & & & & \\
Total Lymp & $2515(2033-2688)$ & $2060(1500-2200)^{\mathrm{a}}$ & $2100(1605-2395)^{\mathrm{b}}$ & $1370(1000-1600)^{\mathrm{c}, \mathrm{e}, \mathrm{f}}$ \\
T & $1737(1446-1933)$ & $1172(934.3-1360)^{\mathrm{a}}$ & $1238(847.3-1599)^{\mathrm{b}}$ & $718(483.7-992.8)^{\mathrm{c}, \mathrm{e}, \mathrm{f}}$ \\
TCD4 & $997.2(813.1-1205)$ & $670(597.2-999.3)^{\mathrm{a}}$ & $724.9(508-951)^{\mathrm{b}}$ & $470.2(274.5-631.2)^{\mathrm{c}, \mathrm{e}, \mathrm{f}}$ \\
TCD8 & $584(403.2-761.8)$ & $322.5(210.1-510.6)^{\mathrm{a}}$ & $380.5(281.1-501.3)^{\mathrm{b}}$ & $213(147.9-359.8)^{\mathrm{c}, \mathrm{f}}$ \\
B & $243(175.2-313.1)$ & $229(127.7-321.4)$ & $165.1(115.5-227.9)^{\mathrm{b}}$ & $82(56.5-137.2)^{\mathrm{c}, \mathrm{e}, \mathrm{f}}$ \\
T naive & $228.5(111.1-337.4)$ & $155.3(86.2-246.9)$ & $106.1(45.4-234.2)^{\mathrm{b}}$ & $89(25.1-138)^{\mathrm{c}, \mathrm{e}}$ \\
TCM & $66.9(44.4-86.8)$ & $68.4(39.6-85.6)$ & $59.1(16.5-75.6)$ & $35(19.6-62)^{\mathrm{c}, \mathrm{e}}$ \\
TEM & $262.5(156.1-421.4)$ & $201.2(145.8-254.2)$ & $234.8(162.3-338.8)$ & $164.4(88.6-230.5)^{\mathrm{c}, \mathrm{f}}$ \\
TEMRA & $354.1(263.8-470.3)$ & $190.5(104.3-315)^{\mathrm{a}}$ & $293.4(107.4-323.3)^{\mathrm{b}}$ & $120(64.6-179.2)^{\mathrm{c}, \mathrm{e}, \mathrm{f}}$ \\
TREG & $24(10.6-29.2)$ & $24.1(15.4-34.5)$ & $12.9(3-16.5)^{\mathrm{d}}$ & $8.9(4.8-18.1)^{\mathrm{c}, \mathrm{e}}$ \\
B naive & $106.5(71.6-132.5)$ & $87.4(34.7-116.2)$ & $49.7(33-75.9)^{\mathrm{b}}$ & $23.4(11.2-47.7)^{\mathrm{c}, \mathrm{e}, \mathrm{f}}$ \\
BM & $69.1(42.6-85.1)$ & $43.9(23.9-70.8)$ & $45.4(26.5-52.5)^{\mathrm{b}}$ & $26.4(7-32)^{\mathrm{c}, \mathrm{e}, \mathrm{f}}$ \\
BREG & $15.5(8.9-22.3)$ & $18.5(9.8-30.5)$ & $12.3(7.1-17.3)$ & $7.5(2.4-15.7)^{\mathrm{c}, \mathrm{e}}$
\end{tabular}

HAd - healthy adults; HEld - healthy elderly; EnAd - end stage renal disease adult patients; EnEld - end stage renal disease elderly patients; Lymp - lymphocyte; T - T lymphocyte; TCD4 - T helper; TCD8 - T cytotoxic; B - B lymphocyte; TCM - T central memory; TEM - T effector memory; TEMRA - T effector memory with RA reexpression; TREG - regulatory T cells; BM - B memory; BREG - regulatory B cells.

Significant difference between: ${ }^{\mathrm{a}} \mathrm{HAd}$ and HEld; ${ }^{\mathrm{H}} \mathrm{HAd}$ and EnAd; ${ }^{\mathrm{c}} \mathrm{HAd}$ and EnEld; ${ }^{\mathrm{H}} \mathrm{HEld}$ and EnAd; ${ }^{\mathrm{e}} \mathrm{HEld}$ and EnEld; ${ }^{\mathrm{f}} \mathrm{EnAd}$ and EnEld

To strengthen the analysis of the combined effects of aging and ESRD testing their possible interaction, we performed a two-way ANOVA with 4 groups in a two-bytwo factorial design. The independent variables were age (elderly vs. younger adults) and ESRD (vs. healthy volunteers).

We attributed the lymphocyte subset change to ESRD if both grouped comparisons (HAd vs. EnAd and HEd vs. EnEld) were in agreement. Similarly, we attributed the lymphocyte subset change to aging if both grouped comparisons (HAd vs. HEd and EnAd vs. EnEld) converged. Isolated ANOVA differences for each condition were also considered relevant.

All differences found in the previous analysis attributed to ESRD and aging were confirmed. There was no synergetic effect in absolute counts or percentages of lymphocyte subsets (table 3 ). In this analysis, again both conditions influenced the percentage of TREG, but with opposite effects. aging resulted in higher percentage of TREG whereas ESRD in lower percentage of TREG.

The following differences were found in two-way ANOVA but not described in the previous comparison. Elderly individuals had significant lower T naive and BM 
absolute counts with lower percentage of TCD8 and TEMRA and higher percentage of TCM lymphocytes than younger adults. ESRD patients had lower absolute counts of $\mathrm{T}$ naive, TCM, BM and BREG with lower percentages of B-cells and higher percentage of TEM cells than healthy volunteers (Table 3 ).

\section{DISCUSSION}

In this study, we analyzed circulating lymphocyte subsets of elderly and young adults with ESRD on admission for their kidney transplantation, along with healthy volunteers, to test the hypothesis that aging and ESRD quantitatively modify peripheral blood T- and B- cell maturation and differentiation profiles. We found that aging affects lymphocyte subpopulation profile of ESRD patients in a similar pattern it affects individuals without ESRD. Aging was associated with global reduction in the absolute numbers of total lymphocytes, TCD4 and TCD8 subsets. The subpopulation changes were more intense in the TCD4 subsets with lower $\mathrm{T}$ naive and TEMRA absolute counts and higher TCM percentage. We found a higher percentage of TREGs without changes in TREG absolute counts. For the B- cells, aging resulted in lower absolute BM counts, with similar subsets percentages.

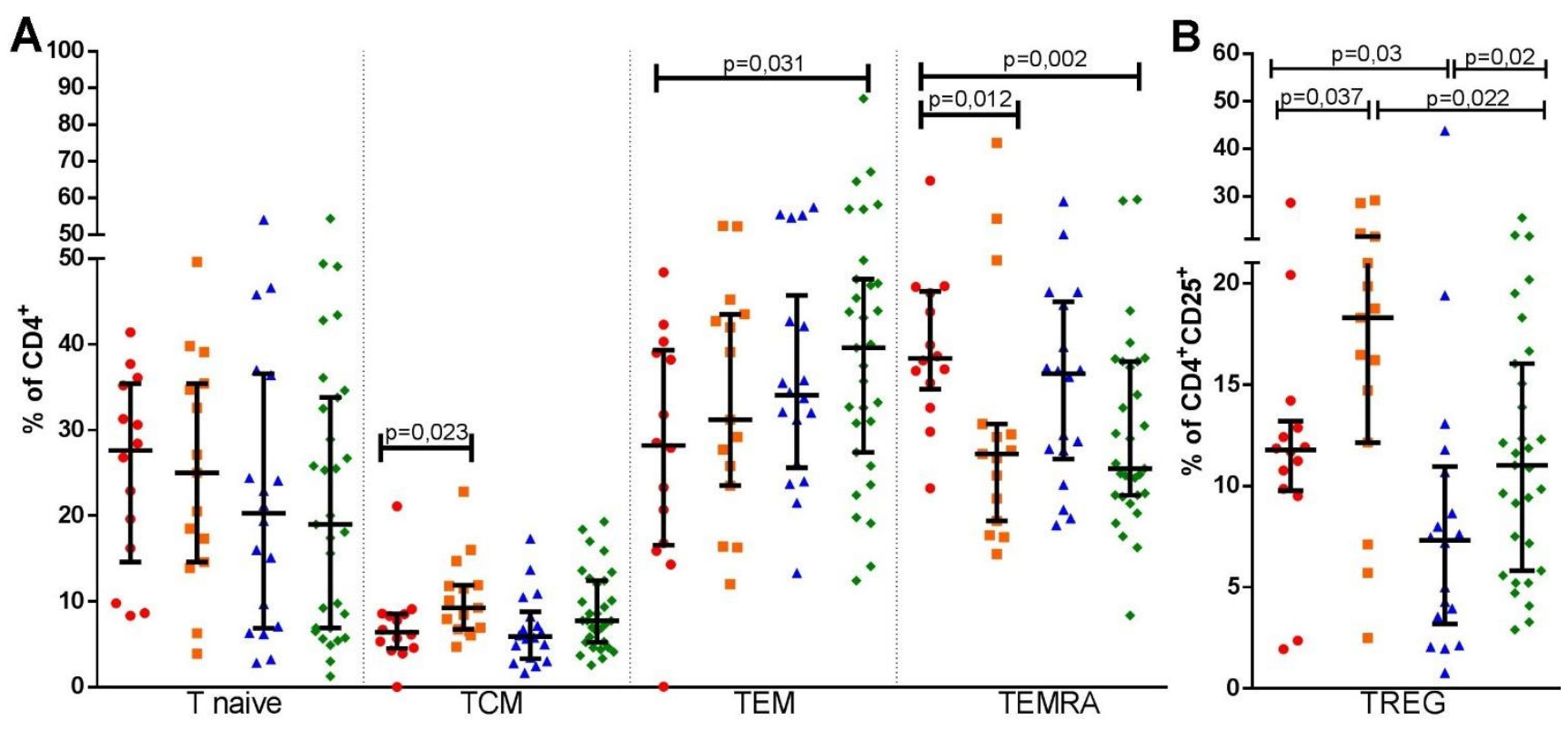

Figure 3. Aging and end stage renal disease effects in T - cells subsets percentages, T naïve, TCM, TEM, TEMRA (A) and TREG (B). Healthy adults $(n=14)(\mathbf{O})$, healthy elderly $(n=15)(\square)$, end stage renal disease adult patients $(n=18)(\boldsymbol{\Delta})$ and end stage renal disease elderly patients $(n=31)(\diamond)$ subsets percentages are shown in the same repeatedly order in each cell subset analysis. TCM - T central memory, TEM - T effector memory, TEMRA - T effector memory with RA reexpression, TREG - regulatory T cells. Bars represent median and interquartile ranges.

Our findings on the T- cells are in agreement with others who described elderly individuals with lower $\mathrm{T}$ naive lymphocyte population [6-8, 29], higher TCM [7] and higher TREG percentage [8, 29, 30]. However, our data conflict with others regarding TEM and TREG. We found no differences in TEM absolute and percentage and TREG absolute counts although others reported higher TEM absolute counts and percentage [6], and higher TREG absolute counts [8]. We found these minor differences in some T-cell subsets, but our findings do support that even among ESRD patients there is a memory shift in T-cell subsets in the elderly along with an increase in regulatory $\mathrm{T}$-cells population.

Studies of B-cells, in aging, describe lower absolute counts and percentage of total B lymphocytes [9, 11-13, $30]$, with a higher percentage of $\mathrm{BM}[10,11,31]$. However, there is no consensus regarding quantitative impact in B naive and BREG percentages that could be unchanged [13] or diminished [11]. Our findings on the B-cells do not support any conclusions of a profile shift in these lymphocyte subsets with aging. The minimal changes observed in our B-cell results may indicate the 
need of a bigger sample size to clearly detect any differences and clarify if aging in ESRD results in any Bcell subset changes

This study supports the following rationale: thymus atrophy is significant in elderly leading to a secondary reduction in thymic output of lymphocyte emigrants, responsible for the replenishment of naive T-cell pool [8, 32, 33] and expansion of peripheral T-cells to maintain counts $[8,32,34,35]$. The net result is an increase in $\mathrm{T}$ cells with memory phenotype. This phenomenon is still relevant in aging even if ESRD is overlaid.

Our data showed that ESRD was also associated with global reduction in the absolute number of total lymphocytes and lower absolute TCD4 and TCD8 cell counts. In TCD4 subsets we found lower absolute counts of T naive, TCM and TEMRA, with higher percentage of TEM. The lower percentage of TREG in ESRD was divergent with our aging findings. The B-cells population, in ESRD, was associated with lower absolute Blymphocyte counts and lower absolute counts of all B-cell subsets.

Table 3. Two-way Analysis of variance for ESRD, age and Age x ESRD interaction.

\begin{tabular}{|c|c|c|c|c|c|c|}
\hline \multirow[b]{2}{*}{ Lymphocyte subsets } & \multicolumn{3}{|c|}{ Absolute } & \multicolumn{3}{|c|}{ Percentages } \\
\hline & Age $^{\mathbf{a}}$ & ESRD & $\begin{array}{l}\text { Age x } \\
\text { ESRD }^{b}\end{array}$ & $\operatorname{Age}^{\mathbf{a}}$ & ESRD & $\begin{array}{l}\operatorname{Age} x \\
\text { ESRD }^{b}\end{array}$ \\
\hline Total & $<0.001$ & $<0.001$ & 0.2 & 0.18 & 0.46 & 0.06 \\
\hline $\mathrm{T}$ & $<0.001$ & $<0.001$ & 0.64 & 0.009 & 0.17 & 0.51 \\
\hline $\mathrm{TCD}^{+}$ & $<0.001$ & $<0.001$ & 0.95 & 0.66 & 0.50 & 0.15 \\
\hline $\mathrm{TCD}^{+}$ & $<0.001$ & 0.001 & 0.45 & 0.007 & 0.41 & 0.41 \\
\hline $\mathrm{B}$ & 0.06 & $<0.001$ & 0.38 & 0.65 & 0.02 & 0.53 \\
\hline T naive & 0.04 & 0.003 & 0.96 & 0.95 & 0.34 & 0.95 \\
\hline $\mathrm{T}$ central memory & 0.41 & 0.001 & 0.76 & 0.02 & 0.39 & 0.62 \\
\hline $\mathrm{T}$ effector memory & 0.054 & 0.37 & 0.53 & 0.19 & 0.03 & 0.79 \\
\hline TEMRA & $<0.001$ & $<\mathbf{0 . 0 0 1}$ & 0.55 & 0.02 & 0.26 & 0.56 \\
\hline Regulatory T cells & 0.52 & $<0.001$ & 0.35 & 0.04 & 0.02 & 0.54 \\
\hline $\mathrm{B}$ naive & 0.06 & $<0.001$ & 0.69 & 0.12 & 0.11 & 0.64 \\
\hline B memory & 0.001 & $<0.001$ & 0.61 & 0.38 & 0.96 & 0.94 \\
\hline Regulatory B cells & 0.98 & 0.04 & 0.79 & 0.07 & 0.32 & 0.94 \\
\hline
\end{tabular}

Abbreviations: ESRD - end-stage renal disease, TEMRA - T effector memory with RA reexpression. $\mathrm{P}$ values are presented. $\mathrm{P}<0.05$ is significant

a Age categories of adults (18-45 years) and elderly ( $>60$ years) were used

${ }^{\mathrm{b}}$ Interaction term for age and ESRD in the statistical model

Our findings of ESRD are in agreement with others', describing lower absolute total lymphocytes [16-18, 20, $36,37]$, T lymphocytes $[15,36,37]$ and TCD4 [15-17, 36, 37], with no changes in the relative percentage of $\mathrm{T}$ lymphocytes [36, 37], TCD4 [16, 36] or TCD8 [17, 36, $37]$, but lower $T$ naive absolute count $[17,37]$, lower absolute TCM lymphocyte counts [17, 37] and higher percentage of TEM lymphocytes [18]. However our data is discordant of others who reported unchanged absolute TCD8 [17, 36, 37], lower T naive percentage [16, 18], higher percentage of TCM [18]. We have also found lower TREG percentage in ESRD which is compatible with a more pro-inflammatory profile described in uremic patients. However this finding contrast with others describing unchanged [16] or lower [15] absolute TREG counts without changes in TREG percentage $[15,16,20$, $38,39]$.

Our data on B-cells in ESRD patients are in agreement with others who also describe lower B lymphocyte absolute counts [15, 36, 37] and percentage [36] with unchanged B naive and BREG percentages [20]. We diverge from others in the BM lymphocytes findings. We saw no changes in BM percentage, although others describe a lower percentage [20].

The reasons for these discrepant results may be related to different composition of the ESRD populations. The mean age difference between our elderly and younger ESRD adults were 30 years ( 35 vs $65 \mathrm{y}$ ) while others present median ages in the $4^{\text {th }}$ and $5^{\text {th }}$ decades $[17,18,20$, 36, 37, 39]. Various studies also included ESRD not always on dialysis [16, 18, 20, 36, 37] and these patients not necessarily were eligible for kidney transplantation [16-18, 20, 36, 37]. Our patients were a mixture of elderly and young adults, all on dialysis for a mean of 3 years and candidates to renal transplantation while patients on dialysis in other studies presented a wide range of time on replacement therapy $[16,36]$. 
The present research supports the idea of premature senescence in T-cell compartment among ESRD individuals with a shift toward a memory profile. CKD leads to premature decline in thymic function [40], increase in memory $\mathrm{T}$-cell with terminal differentiation $[40,41]$ and higher apoptosis occurrence of $\mathrm{T}$ naive cells [40]. Consequently, lymphocyte subset changes resembling aging, with premature immunological senescence $[40,41]$ affecting the T compartment. B-cells seem to present a more prominent absolute count reduction without any significant profile shift. Among elderly individuals aging still have expressive effects.

Despite convergent findings with other reports on CKD and aging effects, our study analyzed, simultaneously, both effects in a number of subsets beyond the usual studies scope. Our greater novelty is the analysis of senescense and ESRD co-occurrence that resulted in greater reduction in all lymphocyte subsets, without synergic effects and little percentage changes, except for higher BREG percentage.

How could these lymphocyte changes be translated into clinical practice of renal transplantation in ESRD elderly patients? It should be pointed that higher BREG and TREG counts correlates with lower acute rejection rates [25, 42], operational tolerance [27], and higher glomerular filtration rates [25]. Also, BREG showed a protective role in kidney transplantation [26]. These findings have implication in selecting immunesuppressive drugs for the elderly recipients. Thymoglobulin, in vivo, results in reduction of TREG absolute counts [43] with percentage elevation [44, 45]. Calcineurin inhibitors (CNI) prevent TREG induction in vitro [46] in a dose dependent fashion [47], while mTOR inhibitors (mTORi) account for peripheral TREG generation in vitro [48] and TREG expansion in clinical practice [49]. Information about the effects of immunosuppressive drugs on BREGs is still scarce. CNIs $[50,51]$ and mTORi [51] seem to result in a BREG decrease, while belatacept seems to favor BREG subpopulation expansion [52].

Besides, these elderly patients may need lower IS exposure and doses $[4,5]$ to avoid both rejection and infection. Lower immunosuppression with relative regulatory sparing could take advantage of the elderly lymphocyte profile maintaining lower acute rejection rates and maybe lowering infection rates. The above rational is in agreement with the selection of low tacrolimus/mTORi immunosuppression in our ongoing clinical study of renal transplantation in the elderly [28].

Despite the relatively small sample sizes that could have influenced statistical discrimination of differences, our samples are similar to other studies with alike subsets evaluation [7, 8, 16, 17, 19, 24]. For final effect of each condition, we only considered significant effects that occurred simultaneously in both condition-grouped analysis. In ESRD analysis the grouped comparisons (HAd vs. EnAd and HEd vs. EnEld) presented opposite age discrepancies, consequently the simultaneously observed differences strengthen the attributed ESRD effects. In aging analysis the grouped comparisons (HAd vs. HEd and EnAd vs. EnEld) presented the same age discrepancies, but the narrower difference of age in the ESRD patients associated with the simultaneously detected differences in the healthy controls strengthen the attributed aging effects. Finally, the same aging and ESRD effects were also present in the two-way analysis of variance comparison. Based on these assumptions the sample sizes and healthy control groups may not be ideal, but they do not preclude our conclusions.

Although the current evolution of genomic technologies has enabled the discovery of important genomic markers that have been shown to correlate with CKD diagnosis and evolution [53], immune senescence [54] and successful aging [55], the current study did not account for these parameters.

In summary, our data show that both aging and ESRD result in decrease of absolute lymphocyte counts with memory profile shift, with divergent effects on TREGS. Immunosuppression regimens, in elderly recipients, that favor TREG and BREG preservation may improve clinical outcomes although a large clinical trial is warranted to prove this hypothesis.

\section{Acknowledgements}

Participated in research design: ED, NZG; participated in the writing of the paper: GRRF, NZG, ED; participated in the performance of the research: all authors contributed new reagents or analytic tools: GRRF, MLF; participated in data analysis: GRRF, MLF, NZG, ED. This work was financially supported by the Kidney Transplantation Service of University of Sao Paulo, Geraldo R R Freitas was supported by Coordenação de Aperfeiçoamento de Pessoal de Nível Superior (CAPES).

\section{References}

[1] Meier-Kriesche HU, Ojo AO, Hanson JA, Kaplan B (2001). Exponentially increased risk of infectious death in older renal transplant recipients. Kidney Int, 59:1539-1543.

[2] Farrugia D, Mahboob S, Cheshire J, Begaj I, Khosla S, Ray D, et al. (2014). Malignancy-related mortality following kidney transplantation is common. Kidney Int, 85:1395-1403.

[3] Danovitch GM, Gill J, Bunnapradist S (2007). Immunosuppression of the elderly kidney transplant recipient. Transplantation, 84:285-291. 
[4] David-Neto E, Agena F, Ramos F, Triboni AH, Romano P, Ebner PA, et al. (2017). Longitudinal Pharmacokinetics of Everolimus when Combined with Low-level of Tacrolimus in Elderly Renal Transplant Recipients. Transplantation, 101:21332138.

[5] David-Neto E, Romano P, Kamada Triboni AH, Ramos F, Agena F, Almeida Rezende Ebner P, et al. (2017). Longitudinal Pharmacokinetics of Tacrolimus in Elderly Compared With Younger Recipients in the First 6 Months After Renal Transplantation. Transplantation, 101:1365-1372.

[6] Saule P, Trauet J, Dutriez V, Lekeux V, Dessaint JP, Labalette M (2006). Accumulation of memory T cells from childhood to old age: central and effector memory cells in CD4(+) versus effector memory and terminally differentiated memory cells in CD8(+) compartment. Mech Ageing Dev, 127:274-281.

[7] Koch S, Larbi A, Derhovanessian E, Ozcelik D, Naumova E, Pawelec GCP (2008). Multiparameter flow cytometric analysis of CD4 and CD8 T cell subsets in young and old people. Immun Ageing, 5:6.

[8] Gregg R, Smith CM, Clark FJ, Dunnion D, Khan N, Chakraverty R, et al. (2005). The number of human peripheral blood CD4+ CD25high regulatory T cells increases with age. Clin Exp Immunol, 140:540-546.

[9] Veneri D, Franchini M, Vella A, Tridente G, Semenzato G, Pizzolo G, et al. (2007). Changes of human B and B-1a peripheral blood lymphocytes with age. Hematology, 12:337-341.

[10] Colonna-Romano G, Aquino A, Bulati M, Di Lorenzo G, Listì $\neg$ F, Vitello S, et al. (2006). Memory B cell subpopulations in the aged. Rejuvenation Res, 9:149152 .

[11] Morbach H, Eichhorn EM, Liese JG, Girschick HJ (2010). Reference values for B cell subpopulations from infancy to adulthood. Clin Exp Immunol, 162:271-279.

[12] Chong Y, Ikematsu H, Yamaji K, Nishimura M, Nabeshima S, Kashiwagi S, et al. (2005). CD27(+) (memory) B cell decrease and apoptosis-resistant CD27(-) (naive) B cell increase in aged humans: implications for age-related peripheral B cell developmental disturbances. Int Immunol, 17:383390.

[13] Caraux A, Klein B, Paiva B, Bret C, Schmitz A, Fuhler GM, et al. (2010). Circulating human B and plasma cells. Age-associated changes in counts and detailed characterization of circulating normal CD138- and CD138+ plasma cells. Haematologica, 95:1016-1020.

[14] Xiang FF, Zhu JM, Cao XS, Shen B, Zou JZ, Liu ZH, et al. (2016). Lymphocyte depletion and subset alteration correlate to renal function in chronic kidney disease patients. Ren Fail, 38:7-14.

[15] Hendrikx TK, van Gurp EA, Mol WM, Schoordijk W, Sewgobind VD, Ijzermans JN, et al. (2009). End-stage renal failure and regulatory activities of CD4+CD25bright+FoxP3+ T-cells. Nephrol Dial Transplant, 24:1969-1978.
[16] Lisowska KA, Dębska-Ślizień A, Jasiulewicz A, Bryl E, Witkowski JM (2014). Influence of hemodialysis on circulating CD4(low)CD25 (high) regulatory $\mathrm{T}$ cells in end-stage renal disease patients. Inflamm Res, 63:99-103.

[17] Yoon JW, Gollapudi S, Pahl MV, Vaziri ND (2006). Naïve and central memory T-cell lymphopenia in endstage renal disease. Kidney Int, 70:371-376.

[18] Chung BH, Kim KW, Sun IO, Choi SR, Park HS, Jeon EJ, et al. (2012). Increased interleukin-17 producing effector memory $\mathrm{T}$ cells in the end-stage renal disease patients. Immunol Lett, 141:181-189.

[19] Pahl MV, Gollapudi S, Sepassi L, Gollapudi P, Elahimehr R, Vaziri ND (2010). Effect of end-stage renal disease on B-lymphocyte subpopulations, IL-7, BAFF and BAFF receptor expression. Nephrol Dial Transplant, 25:205-212.

[20] Kim KW, Chung BH, Jeon EJ, Kim BM, Choi BS, Park CW, et al. (2012). B cell-associated immune profiles in patients with end-stage renal disease (ESRD). Exp Mol Med, 44:465-472.

[21] Yang J, Brook MO, Carvalho-Gaspar M, Zhang J, Ramon HE, Sayegh MH, et al. (2007). Allograft rejection mediated by memory $\mathrm{T}$ cells is resistant to regulation. Proc Natl Acad Sci U S A, 104:1995419959.

[22] Brook MO, Wood KJ, Jones ND (2006). The impact of memory $\mathrm{T}$ cells on rejection and the induction of tolerance. Transplantation, 82:1-9.

[23] Zarkhin V, Kambham N, Li L, Kwok S, Hsieh SC, Salvatierra O, et al. (2008). Characterization of intragraft B cells during renal allograft rejection. Kidney Int, 74:664-673.

[24] Braudeau C, Racape M, Giral M, Louis S, Moreau A, Berthelot L, et al. (2007). Variation in numbers of CD4+CD25highFOXP3+ $\mathrm{T}$ cells with normal immuno-regulatory properties in long-term graft outcome. Transpl Int, 20:845-855.

[25] San Segundo D, Fernández-Fresnedo G, Ruiz JC, Rodrigo E, Benito MJ, Arias M, et al. (2010). Twoyear follow-up of a prospective study of circulating regulatory $\mathrm{T}$ cells in renal transplant patients. Clin Transplant, 24:386-393.

[26] Cherukuri A, Rothstein DM, Clark B, Carter CR, Davison A, Hernandez-Fuentes M, et al. (2014). Immunologic human renal allograft injury associates with an altered IL-10/TNF- $\alpha$ expression ratio in regulatory B cells. J Am Soc Nephrol, 25:1575-1585.

[27] Silva HM, Takenaka MC, Moraes-Vieira PM, Monteiro SM, Hernandez MO, Chaara W, et al. (2012). Preserving the B-cell compartment favors operational tolerance in human renal transplantation. Mol Med, 18:733-743.

[28] David-Neto E AF, Ramos F, Triboni A, Altona M, Coelho V, Galante N, Lemos F. 2016. Everolimus/Low Tacrolimus(TAC) Compared to MPA/RegularTAC for Renal Transplantation in the Elderly Recipient - Preliminary Analysis of the nEverOld Trial. [abstract]. Am J Transplant. 
[29] Lefebvre JS, Haynes L (2012). Aging of the CD4 T Cell Compartment. Open Longev Sci, 6:83-91.

[30] Faria AM, de Moraes SM, de Freitas LH, Speziali E, Soares TF, Figueiredo-Neves SP, et al. (2008). Variation rhythms of lymphocyte subsets during healthy aging. Neuroimmunomodulation, 15:365-379.

[31] Bulati M, Buffa S, Candore G, Caruso C, DunnWalters DK, Pellicanò M, et al. (2011). B cells and immunosenescence: a focus on IgG+IgD-CD27- (DN) B cells in aged humans. Ageing Res Rev, 10:274-284.

[32] Berzins SP, Uldrich AP, Sutherland JS, Gill J, Miller JF, Godfrey DI, et al. (2002). Thymic regeneration: teaching an old immune system new tricks. Trends Mol Med, 8:469-476.

[33] Lynch HE, Goldberg GL, Chidgey A, Van den Brink MR, Boyd R, Sempowski GDCP (2009). Thymic involution and immune reconstitution. Trends Immunol, 30:366-373.

[34] Moro-García MA, Alonso-Arias R, López-Larrea C (2013). When Aging Reaches CD4+ T-Cells: Phenotypic and Functional Changes. Front Immunol, 4:107.

[35] Naylor K, Li G, Vallejo AN, Lee WW, Koetz K, Bryl $\mathrm{E}$, et al. (2005). The influence of age on $\mathrm{T}$ cell generation and TCR diversity. J Immunol, 174:74467452.

[36] Fernández-Fresnedo G, Ramos MA, González-Pardo MC, de Francisco AL, López-Hoyos M, Arias M (2000). B lymphopenia in uremia is related to an accelerated in vitro apoptosis and dysregulation of Bcl-2. Nephrol Dial Transplant, 15:502-510.

[37] Litjens NH, van Druningen CJ, Betjes MG (2006). Progressive loss of renal function is associated with activation and depletion of naive T lymphocytes. Clin Immunol, 118:83-91.

[38] Afzali B, Edozie FC, Fazekasova H, Scottà C, Mitchell PJ, Canavan JB, et al. (2013). Comparison of regulatory $\mathrm{T}$ cells in hemodialysis patients and healthy controls: implications for cell therapy in transplantation. Clin J Am Soc Nephrol, 8:1396-1405.

[39] Lin WX, Christiansen D, Fu LL, Roberts MA, Sandrin MS, Ierino FL (2012). Foxp3+ T cells in peripheral blood of renal transplant recipients and clinical correlations. Nephrology (Carlton), 17:415-422.

[40] Betjes MG, Langerak AW, van der Spek A, de Wit EA, Litjens NH (2011). Premature aging of circulating $\mathrm{T}$ cells in patients with end-stage renal disease. Kidney Int, 80:208-217.

[41] Meijers RW, Litjens NH, de Wit EA, Langerak AW, van der Spek A, Baan CC, et al. (2012). Uremia causes premature ageing of the $\mathrm{T}$ cell compartment in endstage renal disease patients. Immun Ageing, 9:19.

[42] Shabir S, Girdlestone J, Briggs D, Kaul B, Smith H, Daga S, et al. (2015). Transitional B lymphocytes are associated with protection from kidney allograft rejection: a prospective study. Am J Transplant, 15:1384-1391.

[43] Sewgobind VD, Kho MM, van der Laan LJ, Hendrikx TK, van Dam T, Tilanus HW, et al. (2009). The effect of rabbit anti-thymocyte globulin induction therapy on regulatory $\mathrm{T}$ cells in kidney transplant patients. Nephrol Dial Transplant, 24:1635-1644.

[44] Gurkan S, Luan Y, Dhillon N, Allam SR, Montague T, Bromberg JS, et al. (2010). Immune reconstitution following rabbit antithymocyte globulin. Am J Transplant, 10:2132-2141.

[45] Lopez M, Clarkson MR, Albin M, Sayegh MH, Najafian N (2006). A novel mechanism of action for anti-thymocyte globulin: induction of CD4+CD25+Foxp3+ regulatory $\mathrm{T}$ cells. J Am Soc Nephrol, 17:2844-2853.

[46] Baan CC, van der Mast BJ, Klepper M, Mol WM, Peeters AM, Korevaar SS, et al. (2005). Differential effect of calcineurin inhibitors, anti-CD25 antibodies and rapamycin on the induction of FOXP3 in human T cells. Transplantation, 80:110-117.

[47] Miroux C, Morales O, Ghazal K, Othman SB, de Launoit Y, Pancré V, et al. (2012). In vitro effects of cyclosporine $\mathrm{A}$ and tacrolimus on regulatory $\mathrm{T}$-cell proliferation and function. Transplantation, 94:123131.

[48] Chen JF, Gao J, Zhang D, Wang ZH, Zhu JY (2010). CD4+Foxp3+ regulatory $\mathrm{T}$ cells converted by rapamycin from peripheral $\mathrm{CD} 4+\mathrm{CD} 25(-)$ naive $\mathrm{T}$ cells display more potent regulatory ability in vitro. Chin Med J (Engl), 123:942-948.

[49] Morelon E, Lefrançois N, Besson C, Prévautel J, Brunet M, Touraine JL, et al. (2010). Preferential increase in memory and regulatory subsets during $\mathrm{T}$ lymphocyte immune reconstitution after Thymoglobulin induction therapy with maintenance sirolimus vs cyclosporine. Transpl Immunol, 23:5358.

[50] Chung BH, Kim KW, Yu JH, Kim BM, Choi BS, Park CW, et al. (2014). Decrease of immature B cell and interleukin-10 during early-post-transplant period in renal transplant recipients under tacrolimus based immunosuppression. Transpl Immunol, 30:159-167.

[51] Latorre I, Esteve-Sole A, Redondo D, Giest S, Argilaguet J, Alvarez S, et al. (2016). Calcineurin and mTOR inhibitors have opposing effects on regulatory $\mathrm{T}$ cells while reducing regulatory $\mathrm{B}$ cell populations in kidney transplant recipients. Transpl Immunol, 35:16.

[52] Leibler C, Matignon M, Pilon C, Montespan F, Bigot J, Lang P, et al. (2014). Kidney transplant recipients treated with belatacept exhibit increased naïve and transitional B cells. Am J Transplant, 14:1173-1182. Ainsworth HC, Langefeld CD, Freedman BI (2017). Genetic epidemiology in kidney disease. Nephrol Dial Transplant, 32: ii159-ii169.

[54] Ruan Q, Qian F, Yu Z (2014). Effects of polymorphisms in immunity-related genes on the immune system and successful aging. Curr Opin Immunol, 29:49-55.

[55] Di Bona D, Accardi G, Virruso C, Candore G, Caruso C (2014). Association of Klotho polymorphisms with healthy aging: a systematic review and meta-analysis. Rejuvenation Res, 17:212-216. 


\section{Supplementary data}

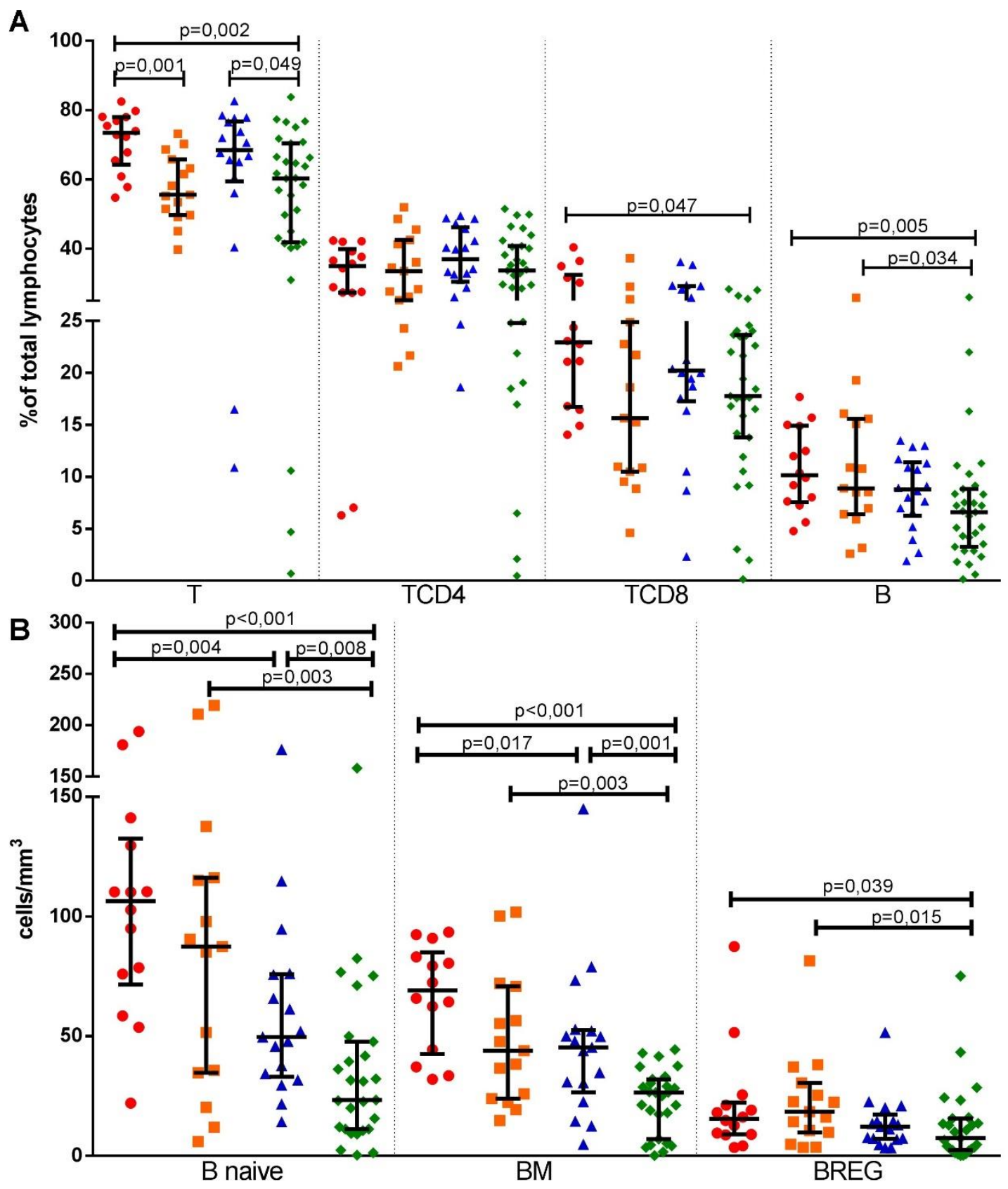

Supplementary Figure 1. Aging and end stage renal disease effects in percentages of T-, TCD4-, TCD8- and B- cells (A) and on B-cells subsets absolute counts $(B)$. Healthy adults $(n=14)(\bigcirc)$, healthy elderly $(n=15)(\square)$, end stage renal disease adult patient $(n=18)$ $(\Delta)$ and end stage renal disease elderly patients $(n=31)(\diamond)$ absolute counts and percentages are shown in the same repeatedly order in each cell subset analysis. T - T lymphocyte, TCD4 - T helper, TCD8 - T cytotoxic, B - B lymphocyte, BM - B memory, BREG regulatory $\mathrm{B}$ cells. Bars represent median and interquartile ranges. 

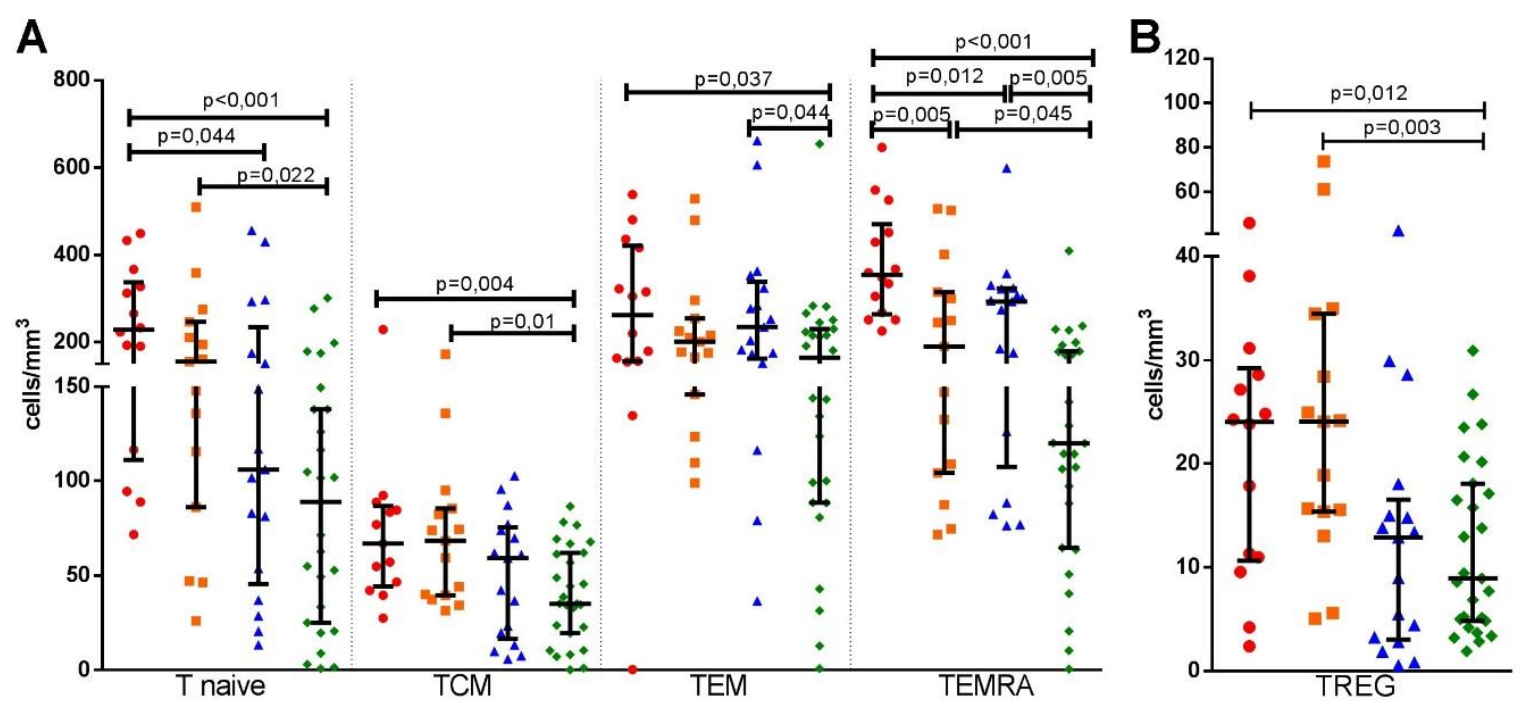

Supplementary Figure 2. Aging and end stage renal disease effects in $\mathbf{T}$ - cells subsets absolute counts, $\mathbf{T}$ naïve, TCM, TEM, TEMRA (A) and TREG (B). Healthy adults $(n=14)(\bigcirc)$, healthy elderly $(n=15)(\square)$, end stage renal disease adult patient $(n=18)(\Delta)$ and end stage renal disease elderly patients $(n=31)(\diamond)$ absolute counts are shown in the same repeatedly order in each cell subset analysis. TCM - T central memory, TEM - T effector memory, TEMRA - T effector memory with RA reexpression, TREG - regulatory T cells. Bars represent median and interquartile ranges. 